(2) 9
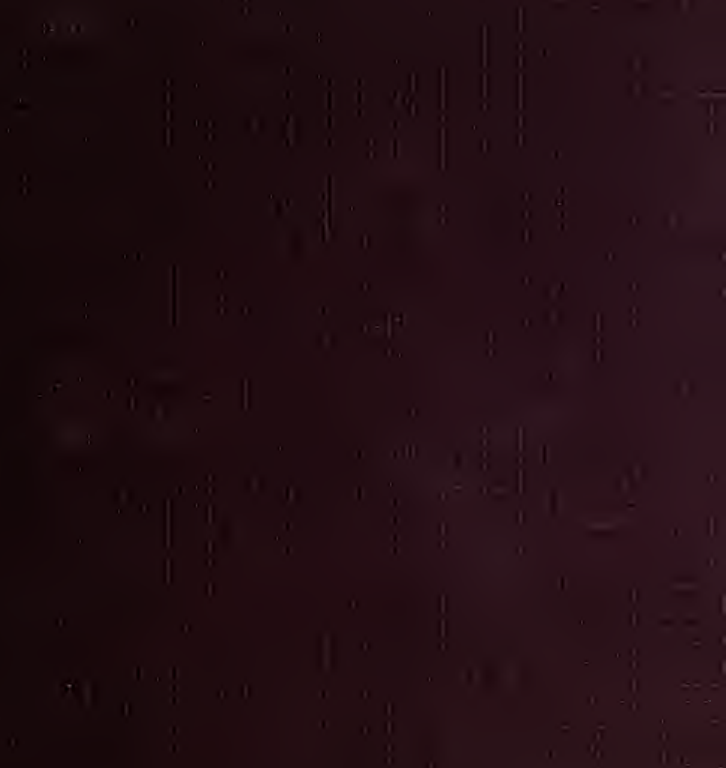

$=18$

1

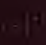




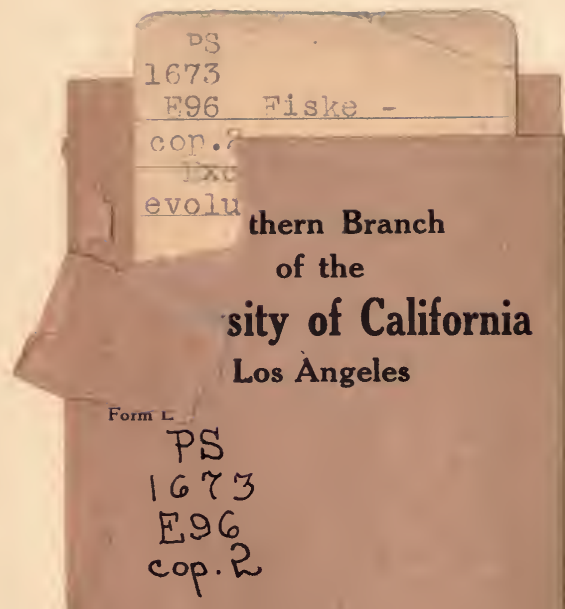


This book is DUE on the last date stamped below

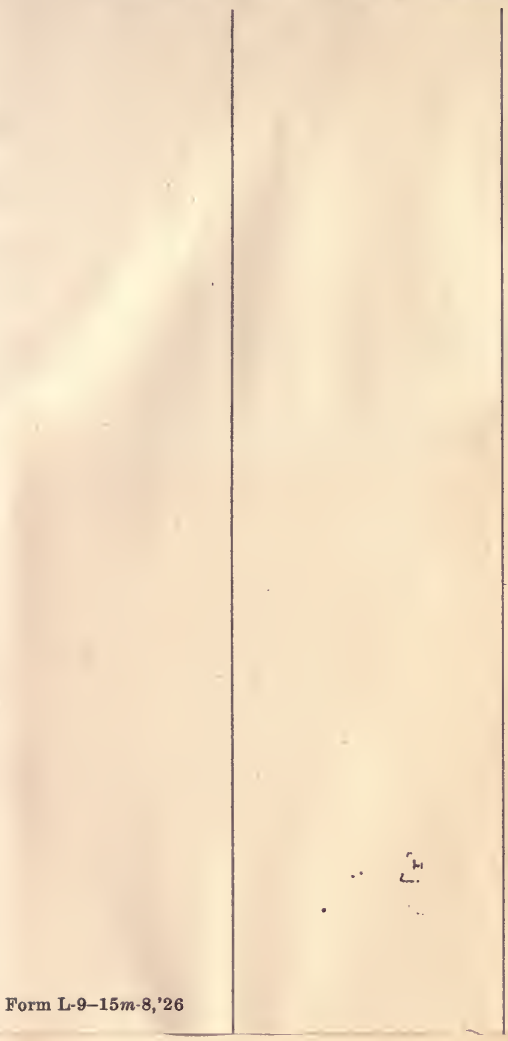





\title{
EXCURSIONS OF AN EVOLUTIONIST
}

\author{
BY \\ JOHN FISKE
}

Willst du ins Unendliche schreiten

Geh nur im Endlichen nach allen Seiten

GoxthI

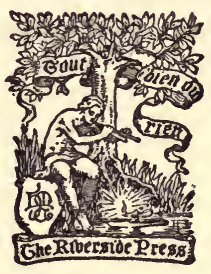

BOSTON AND NEW YORK HOUGHTON MIFFLIN COMPANY

(cbe lituersioe pres Cambrioge 
COPYRIGHT 1883 BY JOHN FISKE

COPYRIGHT I9O2 BY HOUGHTON, MIFFLIN \& CO. COPYRIGHT IGII BY ABBX M. FISKE

ALL RIGHTS RESERVED

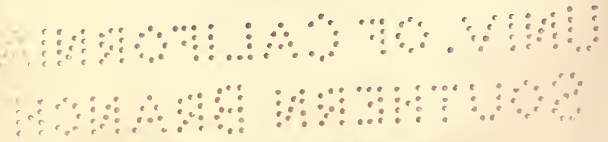




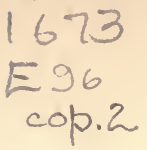

To

REV. JOHN LANGDON DUDLEY.

\section{Dear and Honoured Friend:}

Quarter of a century has passed since I used to listen with delight to your preaching and come to you for sympathy and counsel in my studies. In these later days, while we meet too seldom, my memory of that wise and cordial sympathy grows ever brighter and sweeter; and to-day, in writing upon my title-page the words of the great German seer, my thoughts naturally revert to you. For I know of no one who understands more thoroughly or feels more keenly how it is that if we would fain learn something of the Infinite, we must not sit idly repeating the formulas of other men and other days, but must gird up our loins anew, and diligently explore on every side that finite realm through which still shines the glory of an ever-present God for those that have eyes to see and ears to hear. Pray accept this little book from one who is

Ever gratefully yours,

JOHN FISKE.

Cambridge, October 23, 1883. 



\section{CONTENTS}

PAGI

I. EUROPE BEFORE THE ARRIVAL OF MAN • I

II. THE ARRIVAI. OF MAN IN EUROPE • 33

III. OUR ARYAN FOREFATHERS - • - • 68

IV. WHAT WE LEARN FROM OLD ARYAN WORDS 97

V. WAS THERE A PRIMEVAL MOTHER TONGUE? 132

VI. SOCIOLOGY AND HERO-WORSHIP • - $15^{8}$

VII. HEROES OF INDUSTRY • • • 184

VIII. THE CAUSES OF PERSECUTION • • I9I

IX. THE ORIGINS OF PROTESTANTISM • • $22 \mathrm{I}$

X. THE TRUE LESSON OF PROTESTANTISM • 244

XI. EVOLUTION AND RELIGION • • $\quad 268$

XII. THE MEANING OF INFANCY • • $\quad 279$

XIII. A UNIVERSE OF MIND-STUFF • • • 292

XIV. IN MEMORIAM : CHARLES DARWIN • 308

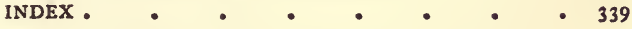





\section{EXGURSIONS OF AN EVOLUTIONIST}

I

EUROPE BEFORE THE ARRIVAL OF MAN

T $\mathrm{N}$ looking over any modern historical narrative - such, for example, as Knight's 1 "History of England" - one cannot fail to be struck by the disproportion between the amounts of space devoted respectively to ancient and to modern events. Of the eight bulky volumes of Knight, the first covers a period of 1432 years, from Cæsar's invasion of Britain to the death of Edward III.; the second, bringing us down to the death of Henry VIII., covers I 70 years; the third takes us 95 years further, to the beginning of the Great Rebellion; while five volumes are required to do justice to the two centuries intervening between the overthrow of Strafford and the repeal of the corn laws. This is due partly to the greater complexity of modern life, and partly to the increasing abundance of our sources of information. It is true, 


\section{EXCURSIONS OF AN EVOLUTIONIST}

we have to go back a long way before we encounter an absolute scarcity of information; there was a great deal more literature in the Middle Ages than is commonly supposed, and it is possible to describe many long past events with great minuteness and accuracy. Mr. Freeman devotes the greater part of a volume of 768 pages to the political and military history of England during the single year 1066. But the history during the spring of $1_{1} 1_{5}$, if treated with equal thoroughness, would fill a good many volumes as big as this; and this is owing largely to our increased wealth of materials. When we go back far enough and encounter a positive dearth of material, we can devote but a few pages to the history of a century, as in the case of the earliest Teutonic invasions of Britain; or, as in the case of the long ages before Cæsar's invasion, we can barely say that such and such races of men inhabited the island, and we can give little or no account of what they did. This is one reason why we find it so hard to form and preserve an accurate mental picture of the duration of past time. It requires a deliberate effort of the mind to realize, for example, that the interval between the proclamation of Constantine the Great by the Roman legions at York and the invasion of William the Conqueror was exactly equal to the interval between the latter event and the accession of George IV., or the 
adoption of the Missouri Compromise. We may know that it is so, but in order to make it seem so, most people will have to stop and think.

The case is somewhat similar when we try to realize the relative duration of the successive geological epochs in the history of the earth's crust. We are naturally inclined to overrate the relative duration of the later epochs. Familiar as we are with the established classification of periods as Primary, Secondary, and Tertiary, we fall naturally into a habit of regarding these three great groups of epochs as substantially equal in value, so that the beginning of the Tertiary period is apt to seem one third of the way back toward the first beginnings of fossilbearing strata. Probably in our every-day thinking the Tertiary period occupies more than a third of the space that is occupied by the whole recorded life history of the earth, - mainly for the reason that it is so much more completely filled for us with familiar and well-ascertained facts. This may be partly because organic life has really been more complex and multiform since the beginning of the Tertiary period than it was in earlier ages; but it is also, no doubt, because our sources of information are far more abundant. On the whole, the geologic record of the Tertiary period is much more completely preserved than that of the two earlier periods; 


\section{EXCURSIONS OF AN EVOLUTIONIST}

we see more clearly into the details of life at that time, and consequently have a more vivid picture of it before us; and this more vivid picture, as is natural, usurps an undue place in our minds.

The force of these remarks will be obvious when it is stated that in point of fact the beginning of the Tertiary period carries us back barely one twentieth part of the way toward the first beginnings of fossil-bearing strata. In the table that follows, I have tried to give something like a just idea of the relative lengths of geological epochs, in accordance with the views now generally adopted by geologists. Let us first suppose the entire lapse of time since the oldest Laurentian strata began to be deposited, down to the present day, to be divided into ten equal periods, or æons, such as I have marked off on the table with dotted lines. Then the Laurentian epoch fills three of these great æons, to begin with. Here we find (with the exception of the Canadian eozoön, the organic nature of which has been disputed) only indirect traces of life, such as limestone, which probably came from shells. But, remembering how soft and perishable are all the lowest organisms, and remembering how considerably these oldest rocks have been affected by volcanic heat, we need not be surprised at finding the records of life in them very scanty and obscure. Next, the Cambrian 


\section{EUROPE BEFORE ARRIVAL OF MAN}

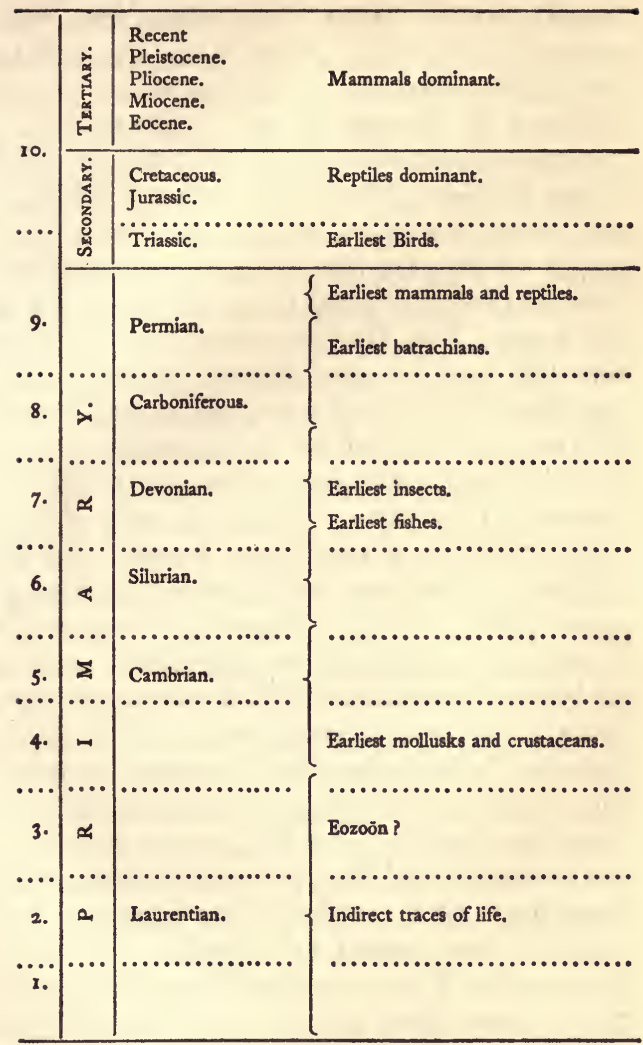




\section{EXCURSIONS OF AN EVOLUTIONIST}

epoch extends into the sixth æon, and then comes the Silurian, which takes us halfway through the seventh. Mollusks and crustaceans swarmed in the seas of the Cambrian epoch, but there are as yet no traces of fish before the upper Silurian. That is to say, three fifths of the whole duration of geological time had elapsed before the lowest vertebrate forms had begun to leave plentiful traces of themselves in the rocks. The Devonian epoch, in which we find the first record of insects, carries us halfway through the eighth æon ; and we are brought well on into the ninth by the Carboniferous age, in which appear the earliest air-breathing vertebrates in the shape of frog-like amphibians. The vegetation of this period consisted chiefly of ferns, club-mosses, and horse-tails with araucarian pines. Nearly nine tenths of the past life history of our globe accomplished, and as yet no birds or mammals, perhaps no true reptiles, nor any tree save the araucaria or the arborescent fern! With the Permian epoch we reach the end of the Primary period, and nearly complete our ninth æon, leaving for the whole of the Secondary and Tertiary periods only a little more than one æon to be divided between them. The oldest mammals and reptiles yet found belong to the Trias, or earliest Secondary epoch ; yet so many small mammalia, inferior in type to the marsupials, have been found by Professor 


\section{EUROPE BEFORE ARRIVAL OF MAN}

Marsh far down in the Trias as to warrant the belief that mammals had appeared on the scene toward the close of the Permian age; and no doubt the same will prove true of reptiles. Some of the footsteps on the Triassic rocks of the Connecticut valley are probably footsteps of great struthious birds; but the oldest bird actually known belongs to the upper Jurassic strata. Throughout the Secondary period the real lords of the creation were the giant reptiles, stalking over the earth, splashing through the sea, and flying on swift bat-like wing overhead. Of these innumerable "dragons of the prime," the iguanodon, from fifty to seventy feet in length, used to be supposed the largest; but Professor Marsh has lately discovered the atlantosaurus of Colorado, nearly one hundred feet in length and thirty feet in height, - the largest land animal as yet known. The mammals contemporary with these monsters seem to have been mostly small insect-eating marsupials ; and the forests through which they roamed consisted mainly of palms, tree-ferns, and pines. In the Cretaceous epoch such deciduous trees as the oak and walnut had appeared on the scene, and the great reptiles had become less numerous. But it is not until we enter the Tertiary period, halfway through our tenth æon of geological time, that the face of the earth, with deciduous trees and flowering herbs, and mam- 


\section{EXCURSIONS OF AN EVOLUTIONIST}

mals dominant in the animal world, could have begun to assume anything even distantly resembling the aspect under which we know it. Yet if we could be suddenly taken back, and permitted to inspect a landscape of the earliest Tertiary epoch, we should probably be far more forcibly struck with the differences than with the points of resemblance.

In this succinct view I have supposed the whole of the life history of our planet to be arbitrarily divided into ten equal periods. What, it may be asked, is supposed to have been the actual duration of one of these xons? I am well aware that to such a question no definite answer can be given. The geologist deals only with relative, not with absolute, quantities of time: he can only say that the time has been - long enough for a certain enormous amount of work to be performed, but he has nothing with which to measure its duration in years. Nevertheless, while fully admitting all this, one may perhaps venture to give a provisional answer for a provisional purpose. For the present it will be enough to recall Sir William Thomson's ingenious speculations as to the limits of the antiquity of life upon the earth. Reasoning from the sources of the sun's heat, and from the length of time which it would take a body like the earth to cool so as to produce the present increment of tempera- 


\section{EUROPE BEFORE ARRIVAL OF MAN}

ture as we go beneath the surface, Sir William Thomson concludes that the crust of the earth cannot possibly have existed in the solid state for more than four hundred million years, and in all probability has not been solidified and in fit condition for the support of vegetable and animal life for more than one hundred million or two hundred million years. This conclusion is largely speculative, including several data of which our knowledge is far from complete, and it is of course extremely indefinite. It makes a good deal of difference whether life has existed on the earth for one hundred million years or for two hundred millions, since one period is just twice as long as the other. Still, in spite of this indefiniteness, there is a growing disposition among geologists to accept Sir William Thomson's estimate, as showing at least the order of magnitudes with which the geological chronologer must deal. That is to say, while it may not be clear whether life has existed for one or for two hundred millions of years, it is not at all probable that it has existed for a thousand millions or for any greater period. Even this amount of limitation is of some value as giving definite shape to our ideas, and as reminding us that geologists who have habitually reasoned as if there were an infinite fund of past time at their disposal have probably been in error. Provided we do not forget that Sir Wil- 


\section{EXCURSIONS OF AN EVOLUTIONIST}

liam Thomson's conclusion contains more or less that is hypothetical, it is well enough to adopt it provisionally; and I shall do so here. Of the ten æons, then, into which I have supposed geological time to be divided, we will suppose that each is about ten million years in duration; bearing in mind that, while it is highly improbable that the lapse of time has been very much less than this, it may not improbably have been considerably greater. According to this, the minimum antiquity for the beginning of the Eocene period would be about five million years.

If these periods seem short in comparison with the enormous quantity of work that has been done, both in the tearing down and rebuilding of the earth's crust and in the modification of the forms of animals and vegetables, it is no doubt largely due - as both Mr. Darwin and Mr. Croll have reminded us - to the fact that it is almost impossible for us to frame an adequate conception of what is meant by a million years. We are wont to use these great arithmetical figures glibly, and without comprehending their import. Mr. Croll has done something to help us in this matter. "Here is one way," he says, " of conveying to the mind some idea of what a million of years really is. Take a narrow strip of paper, an inch broad or 
more, and 83 feet 4 inches in length, and stretch it along the wall of a large hall, or round the walls of an apartment somewhat over 20 feet square. Recall to memory the days of your boyhood, so as to get some adequate conception of what a period of a hundred years is. Then mark off from one of the ends of the strip $\frac{1}{10}$ of an inch. The $\frac{1}{10}$ of the inch will then represent one hundred years, and the entire length of the strip a million of years. It is well worth making the experiment, just in order to feel the striking impression that it produces on the mind." Mr. Croll further reminds us that if we could see side by side a million of years as represented in figures and a million of years as represented in geological work, our respect for a unit with six ciphers after it would be notably increased. "Could we stand upon the edge of a gorge a mile and a half in depth, that had been cut out of the solid rock by a tiny stream, scarcely visible at the bottom of this fearful abyss, and were we informed that this little streamlet was able to wear off annually only $\frac{1}{10}$ of an inch from its rocky bed, what would our conceptions be of the prodigious length of time that this stream must have taken to excavate the gorge? We should certainly feel startled when, on making the necessary calculations, we found that the stream had per- 


\section{EXCURSIONS OF AN EVOLUTIONIST}

formed this enormous amount of work in something less than a million of years." 1

Now all the fossil-bearing rocks on the globe have been formed from the sediment brought down by rivers to the sea, and this sediment has been worn off from the hills and valleys and plains of ancient continents. In recent years it has been attempted to calculate the amounts of sediment worn off by various great rivers from the surface of the regions drained by them ; and the results are very interesting and instructive. The Mississippi, for example, draining a country with scanty rainfall, and having its sources in the Alleghanies and the Rocky Mountains, where there are no glaciers, performs its work of denudation slowly. The Mississippi wears off from the whole immense area drained by it about one foot in 6000 years. While the Po, on the other hand, having its sources in the glaciers of the Alps, works with great rapidity, and lowers the area drained by it at the rate of one foot in 729 years. The mean rate of denudation over the globe seems to be not far from one foot in 3000 years. Now at this rate, and from the action of rivers alone, it would take only two million years to wear the whole existing continent of Europe, with all its huge mountain masses, down to the sea-level, while North America, in similar wise, would be washed away in less than three millions.

1 Croll, Climate and Time, p. 327. 


\section{EUROPE BEFORE ARRIVAL OF MAN}

But while the raindrops, rushing in rivers to the sea, are thus with tireless industry working to obliterate existing continents, their efforts are counteracted, here and there, and with more or less success, by slow upward thrusts or pulsations from the earth's interior, which gradually raise the floors of continents. The general result of the struggle has been that, ever since the earliest geological periods, the surfaces of the great continents now existing have been subject to irregular oscillations; now partially or almost entirely disappearing beneath the sea, now recovering ground as archipelagoes, or rising high and dry to great elevations, as in the case of Africa. The oscillations have not ordinarily exceeded from 6000 to 10,000 feet in vertical extent. There is no reason for supposing that the general relative positions of the great continents and great oceans have altered at all since the beginning of the Laurentian period. Since life began on the earth there is no reason for supposing that the bottoms of the stupendous abysses which hold the waters of the Atlantic, the Pacific, and the Indian oceans have ever been raised up so as to become dry land. Once geologists thought otherwise, and land was turned into sea and sea into land, by facile theorizers, as often as it was supposed to be necessary to account for the distribution of certain lizards or squirrels, or for changes in climate, such as have left marks behind in many parts of 


\section{EXCURSIONS OF AN EVOLUTIONIST}

the earth. The greatest physical geologists now living, however, - such as Mr. Croll and the brothers Geikie, - are convinced that there has been no considerable change in the positions of the great oceans from the very beginning; and this view is ably sustained by Mr. Wallace who is probably the highest living authority on the distribution of plants and animals - in his profound and fascinating treatise on "Island Life," lately published.

Though the general relative positions of deep sea and continent have not altered, however, there have been frequent and striking changes in the superficial contour of land and sea. Every continent has been several times wholly or in part submerged, while shallow portions of what is now sea-bottom have been thrust up high and dry; and in this way the climate and the mutual relations of floras and faunas have been variously and vastly affected. Thus, during the Silurian period, the dry land of Europe lay mostly in the north, over Finland, Scandinavia, and the German Ocean, covering also the British Islands, and stretching more than two hundred miles out into the Atlantic. The central and southern parts of Europe were then covered by a shallow sea, with islands on the sites of Bavaria and Bohemia. The duration of this state of things may be dimly imagined when we consider the enormous quantity of sediment worn off from this northern con- 
tinent, and now constituting the Silurian rocks of Europe. If all this sediment were to be arranged in a longitudinal pile, according to Professor Archibald Geikie, it would make a mountain ridge 1800 miles long, 33 miles wide, and somewhat higher than Mont Blanc. At the close of this long period ridges of land had begun to appear on the sites of Spain and Switzerland. By the Carboniferous period the central parts of Europe had risen so as to form an archipelago of low islands, surrounded by lagoons and salt marshes, covered with dense jungles of ferns and club-mosses. On the islets grew thick forests of pine, and as repeated epochs of submergence brought all this teeming vegetation under water, it became covered with detritus of mud and sand from the northern highlands, and in this way was preserved to form the coal-beds of Europe. By the Triassic period we find the general elevation of Europe increased, so that instead of an archipelago lying amid lagoons we have a continent thickly dotted over with salt lakes; but in the next or Jurassic period the whole centre of the continent was laid under water again. The extent and shape of the European sea of the Cretaceous period are indicated by the extent of the chalk which was formed on its floor, and of which Professor Huxley has given such a graphic account in his lecture " On a Piece 


\section{EXCURSIONS OF AN EVOLUTIONIST}

of Chalk." 1 The greater part of Europe might then have been called a "Mediterranean Sea," extending from England far into central Asia.

The western highlands of Scotland remained above water, but Bohemia, Switzerland, Spain, and the Caucasus seem to have been submerged, or reduced to islands. Still further submergence occurred during the Eocene period, and this in turn was followed by a long series of elevations, resulting in something like the configuration of Europe as we know it. Late in the Eocene period the Pyrenees, Apennines, Alps, Carpathians, and Caucasus had risen to their present or even to higher altitudes. While an inland sea flowed over the Netherlands and Normandy, the rest of Gaul was dry land, and at its northwestern extremity was joined to Britain. The British Islands, in turn, were joined to each other and to Scandinavia and Spitzbergen, as also to Iceland and Greenland. If Columbus had lived in those days, he could thus have walked on solid land all the way from Spain to the New World.

Two immediate consequences of this great upraising of land made the Eocene period an era of singular interest in the history of the European continent. The first was the invasion of Europe by placental mammals, which speedily supplanted the lower forms that had

1 Huxley, Lay Sermons, pp. 192-222. 
preceded them. The second was the immigration of deciduous trees from the polar regions. Before the Cretaceous period no such trees had been known in any part of the earth, and it is the opinion of Count Saporta that the habit of dropping the leaves was evolved in adaptation to the extreme differences between summer and winter temperatures which characterized the polar regions. However that may be, it is certain that during the Eocene and Miocene periods deciduous trees and shrubs advanced from Greenland and Spitzbergen into Europe, and rapidly covered the face of the country, evolving gradually a great diversity of forms. By the middle Eocene, along with cypresses, pines and yews, fan-palms and pandanus and cactus of giant size, the oak and the elm, the maple, willow, beech, and chestnut, as well as the gum and bread-fruit trees, flourished in Britain. The climate of western and central Europe was tropical, as is shown both by the abundance of palms and by the presence of crocodiles and alligators in large numbers, while the mollusks were such as are now found only in tropical waters.

But the most interesting feature of Eocene Europe was the peculiar character of its mammalian fauna. At first we find marsupials, and carnivora with marsupial affinities, showing that the order of carnivora was then only beginning to be evolved. Afterward came such creatures 


\section{EXCURSIONS OF AN EVOLUTIONIST}

as the anchitherium, the ancestor of the horse, in general aspect somewhere between a Shetland pony and a pig, and with three separate hoofs on each foot. There were also the anoplotheria, or common ancestral forms of antelopes and deer, as yet without horns or antlers. The highest order of mammals, the Primates, - including man, ape, and lemur, - was then represented by the adapis of the Paris basin, the necrolemur of southern France, and the canopithecus of Switzerland. Now none of these Eocene primates answered to any living genus of lemur, though the lemurs are the least specialized of primates now existing; but all these Eocene primates showed signs of relationship, in one way or another, to the hoofed quadrupeds living at that time, which, as we must not forget, were only on the way toward becoming hoofed quadrupeds such as we know. Cousinship, however remote, between such extremely specialized creatures as the horse and his rider seems odd to think of ; yet the lemuroids of the Eocene furnish the link. And it is interesting to remember that, owing to the closeness of relationship, the lemuroid adapis was actually mistaken by Cuvier for an anoplotherium, or primitive antelope-deer. Of all anatomical contrasts, what can be greater than the contrast between a solid hoof and the flexible five-fingered hand of a Rubinstein? Yet the Eocene great-uncle 


\section{EUROPE BEFORE ARRIVAL OF MAN}

of our modern pianists could be mistaken for his contemporary great-uncle or great-grandfather of our hoofed quadrupeds! And this instance is but one fair sample out of many of the changes which the last five or six million years have wrought. Speaking generally, it may be said that in the Eocene age there were carnivora, and there were ungulata, and there were primates; but these orders were not so clearly distinguished from each other as they are to-day, and they were not so clearly distinguished from other orders, such as the rodents and insectivora, while in many cases they had not ceased to bear the marks of their marsupial ancestry. Or, to put the case in another way, in the Eocene period you have an instance of hoofed quadruped, but you find no instance of any such special form as horse or deer or camel ; you find carnivora, but you do not find a clear instance of felis or canis or ursus, - not even of hyæna, an earlier type than either of the others; and you find primates, but among these there is nothing yet so clearly distinguished as a monkey. In short, the present species or genera of mammals had not come into existence in the Eocene period, but only the present orders and some of the present families; and even the orders were not clearly distinct from one another, as they are at present; but they were closely interlocked, very much as species are at present. In other words, 


\section{EXCURSIONS OF AN EVOLUTIONIST}

the whole class of mammals in the Eocene age was far less highly specialized than it is at the present time.

From these premises Mr. Boyd Dawkins argues, with convincing force, that man could not possibly have existed in Europe, and probably nowhere on the earth, during the Eocene period. At a time when the order of ungulates had not clearly developed the distinction between camels and pigs and horses, and when the order of primates was only just beginning to be distinguished from other orders, so that Cuvier could even mistake a primate for an ungulate, - at such a time was it at all likely that man, the most highly specialized of all primates, or of all animals, could have existed ? Obviously, he could not have existed at such a time. The supposition is absurd on the face of it. As Mr. Boyd Dawkins says, "to seek for highly specialized man in a fauna where no living genus of placental mammal was present would be an idle and hopeless quest."

Coming to the Miocene age, we find traces of extensive submergences of parts of the European continent, followed by reëlevations. Considerable portions of Gaul and Italy were laid under water, and at one time the whole basin of the Danube was covered by a sea which connected with the Mediterranean near Berne, thus reducing Switzerland and Italy to 
an archipelago. The Alps, however, seem to have maintained a relative height as great as that of to-day, in comparison with the lands about them. The elevated position which Britain had occupied in the Eocene age seems to have been kept up during the Miocene. The whole of Britain and Ireland, with the English and Irish channels, the German Ocean, and the Atlantic ridge between Scotland and Greenland, stood at an average of nearly 3000 feet higher than they do to-day, so that the whole region remained dry land, and Gaul was still joined in this way to Scandinavia and North America. Above this high level the Scottish Highlands and the Welsh peaks rose to a height of some 7000 feet, having since been worn down to half that height by rain and ice. Many of these great mountains, thus standing nearly as high above sea-level as the Alps, were active volcanoes; and this chain of volcanoes, of which Hecla is now the most famous remnant, extended across the Atlantic ridge, all the way from Wales to Greenland, which was then covered with a luxuriant vegetation of oaks and chestnuts, vines and magnolias. In the earlier part of the Miocene age the general climate of Europe resembled that of Algiers or Louisiana at the present day, but at the close of the period it had become somewhat cooler, though still sub-tropical. Gigantic conifers, like the famous 


\section{EXCURSIONS OF AN EVOLUTIONIST}

trees of California, $40^{\circ}$ feet in height and 25 or more in thickness, flourished all over Europe, from Italy to Norway. Along with these there were cycads, fan-palms, palmettos, figs, laurels and myrtles, poplars, oaks, lindens and maples, acacias and elms, camphors and cinnamons and sandalwood; while ivies and bignonias grew in great luxuriance. Cranes, flamingoes, and pelicans were common, as also geese, herons, pheasants, paroquets, and eagles. But the mammals, in this as in the preceding epoch, present the most instructive subject of study. Opossums were still present, but had vanished before the middle of the period; and a few existing genera of placental mammals had come upon the scene. There were tapirs and small rhinoceroses, as well as squirrels, moles, and hedgehogs, and carnivores similar to the weasels and civets. Collateral ancestors of the deer and antelope roamed about in large herds, and by the middle of the period had begun to acquire small horns and antlers. In mid-Miocene times the anchitheres disappeared, and were succeeded by the hipparion, much nearer in structure to the horse. The mastodon came in about the same time, and with him another elephant-like creature, the deinotherium, who lived in the water like a hippopotamus. Carnivores of the cat family reached their highest point of development as regards size and power in the middle and upper 


\section{EUROPE BEFORE ARRIVAL OF MAN}

Miocene: the machairodus, or sabre-toothed lion, was much larger and more formidable than any lion or tiger now existing. The same period witnessed the arrival in Europe of true apes and baboons, and even of two species of anthropoid ape, allied to the gibbons, one of which, the dryopithecus, was as large as a man, and has been regarded as in some respects superior to any modern anthropoid ape.

Mr. Boyd Dawkins - to whose admirable treatise on "Early Man in Britain " this essay is under great obligations - argues forcibly against the probability that man occupied Europe during any part of the Miocene period. All the species of Miocene land mammals, and several of the genera, are now extinct; and $\mathrm{Mr}$. Dawkins urges that if man existed at that remote period it is incredible that he alone should have subsisted unchanged amid the destruction or metamorphosis of all otherspecies. But it seems to me that Mr. Dawkins partly answers this argument himself when he observes that, "were any man-like animal living in the Miocene age, he might reasonably be expected to be not man, but intermediate between man and something else, and to bear the same relation to ourselves as the Miocene apes, such as the mesopithecus, bear to those now living, such as the semnopithecus." Why may not such a semi-human man have existed in the Miocene age, the race hav- 


\section{EXCURSIONS OF AN EVOLUTIONIST}

ing undergone since then changes parallel to those which have affected the apes, or to those which have affected generally such Miocene genera as have survived down to our times? No remains of any such creature have been found, but it is indisputable that artificially chipped flints and the artificially cut rib of an extinct species of manatee have been discovered in mid-Miocene strata in France. Mr. Dawkins is inclined to adopt M. Gaudry's suggestion that the flints may have been chipped and the rib cut by the great man-like ape, the dryopithecus; for although it is not known that any existing apes are in the habit of chipping flints or cutting bones, yet it is not impossible that the dryopithecus may have somewhat surpassed the present apes in intelligence. On the other hand, M. de Mortillet regards these relics as conclusive proof of the existence of man in mid-Miocene Gaul. The question can hardly be decided at present; but it does not seem to me that Mr. Dawkins's line of argument, which is so conclusive when applied to the Eocene age, is equally conclusive when applied to the Miocene. At an epoch when there were no true apes as yet to be found, when even the lemurs bore marks of kinship with the ancestors of ruminants and pachyderms, and when the carnivorous type was but half developed, it would clearly be idle to expect to find traces of 
man. But in an epoch when many modern genera had come into existence in all the principal orders, and when in particular there existed an ape as high, or higher, in organization than the modern chimpanzee or gorilla, I can see no such overwhelming improbability of the existence of man himself. No doubt, however, if the remains of Miocene man are ever to be found they will disclose a type of humanity quite different from, and very likely much lower than, any that we now know. It is not at all improbable that such remains will by and by be discovered in some part of the earth, if not in Europe. By the time the strata of Africa have been explored with anything like the minuteness with which those of France and England have been examined, we shall be very likely to meet with clear indications of the former presence of half-human man, and it will not be strange if such indications lead us far back into the Miocene epoch.

In the Pliocene period the geographical structure of Europe began to be much more like what it is to-day. Hitherto, during the greater part of the Tertiary epoch, large portions of Russia and Siberia had been submerged, so that the continent of Asia did not extend nearly so far north as at present. A belt of sea appears to have stretched from the eastern $\mathrm{Bal}$ tic across to the Persian Gulf, including the areas 
of the Black and Caspian seas; and another wide channel seems to have run west of the Ural Mountains, connecting the Caspian area with the Arctic Ocean, so that the warm waters of the Indian Ocean found a free passage to the very shores of Finland and Scandinavia. According to Professor Archibald Geikie, these shallow seas disappeared early in Pliocene times, leaving the Aral, Caspian, and Black seas in something like their present isolation. While eastern Europe thus began to acquire its present contour, equally remarkable changes occurred at the same time in the west. The Atlantic ridge between Britain and Greenland was submerged, thus separating Europe from America, and the connections of Norway with Spitzbergen on the one hand and Scotland on the other were also severed by the encroachments of the North Sea. But the British Islands were still joined to each other and to the Gaulish mainland; the whole of Britain jutting out from the continent as a great triangular peninsula, with the Shetlands in the apex. The volcanoes of northwest Britain gradually lost their fires during the Pliocene age. Icebergs appeared in the North Sea, and the general climate of Europe, though still milder than to-day, was much colder than it had been during the Eocene and Miocene epochs. The vegetation began to lose its subtropical aspect. Bamboos, evergreen oaks, and 


\section{EUROPE BEFORE ARRIVAL OF MAN}

magnolias still mingled with maples, willows, and poplars in the latitude of Lyons, but the cinnamon-trees and palms became restricted to Italy. Among mammalia, the first species that has continued to live down to the present time, namely, the African hippopotamus, appears in the upper Pliocene strata of Auvergne. The earliest true elephant, though of a species now extinct, appears at about the same time; and contemporary with him were two species of mastodon, of enormous size, a rhinoceros, a tapir, two or more bears, the giant sabre-toothed lion, an ancestor of the panthers and lynxes, and two kinds of hyæna. There were many species of deer, with antlers, but for the most part unlike modern deer. The ox appears first in the upper Pliocene, but without horns. There were also wolves, and swine, and two kinds of ape. The hipparion still lived, but was becoming scarce, and along with him existed a horse, less specialized in teeth and feet than the modern horse.

Now from the fact that of these Pliocene mammals every one has long since become extinct except the hippopotamus, Mr. Dawkins again proceeds to argue that it is not likely that man inhabited Europe at that period. The alleged instances, three in number, of the recurrence of human remains in Pliocene strata of France and Italy he pronounces unsatisfactory ; and he does not even mention the brilliant in- 


\section{EXCURSIONS OF AN EVOLUTIONIST}

vestigations of the Geological Survey of Portugal, which have brought to light flint implements of undoubted human workmanship, in great abundance in the Pliocene strata of that country, buried under I 200 feet of superincumbent rock. These discoveries, set forth by $M$. Ribeiro in 1871, are cited by Professor Whitney as furnishing conclusive evidence of the presence of man in Portugal during the Pliocene period. In his admirable memoir on "The Auriferous Gravels of the Sierra Nevada," Professor Whitney has collected a great amount of evidence which seems to prove that man existed in California at an equally remote date. Now it is perfectly clear that the human race must have been in existence for a very long time before it could have become so widely dispersed over the earth as to occupy countries so distant from each other as California and Portugal. For the first appearance of man on the earth we must, therefore, go far back in the Pliocene period at any rate; and if we are to find traces of the " missing link," or primordial stock of primates from which man has been derived, we must undoubtedly look for it in the Miocene.

Of the three stages of the Tertiary period here passed in review, we have seen that the Eocene was characterized by the entire absence of genera and species of mammals identical with those now living; in the Miocene there were 


\section{EUROPE BEFORE ARRIVAL OF MAN}

genera, but no species, identical with those now living; in the Pliocene there was at least one species in Europe that has survived to the present day. When we come to the Pleistocene age, we find a majority of the species identical with such as still exist. But in regard to this Pleistocene fauna there are some curious circumstances, which show that the climate of Europe had begun to be subject to vicissitudes such as it had not known in the earlier Tertiary epochs. Among the Pleistocene mammals of Europe we find such as are characteristic of warm climates, - as the lion, leopard, hyæna, elephant, rhinoceros, and hippopotamus; and along with these we find such as characterize sub-arctic climates, - as the musk-sheep, reindeer, glutton, arctic fox, ibex, and chamois ; and yet again we find such denizens of the temperate zone as the bison, horse, deer, wild boar, brown and grizzly bears, wolf, and rabbit, to which may be added the mammoth and woolly rhinoceros. Now, as Mr. James Geikie has ably shown, this singular juxtaposition of northern, southern, and temperate forms points directly to great vicissitudes of climate. It is quite clear that when the reindeer came down as far as southern France, the climate must have been very different from what it was when the hippopotamus bathed in the Thames. We know otherwise, from purely geologic evidence, that the Pleistocene climate was very 


\section{EXCURSIONS OF AN EVOLUTIONIST}

extraordinary. Hitherto, during the Tertiary period, the temperature of Europe seems to have been steadily but slowly decreasing, from the Eocene epoch, when it was sub-tropical, to the end of the Pliocene, when it was temperate, though warmer than at present. But in the Pleistocene epoch there were at least four or five, and probably several more, extreme changes from a warm to a cold climate, and back again. This period, or the greater part of it, has been known as the "Glacial Epoch" or the "Great Ice Age;" but recent researches have shown that over Britain and central Europe there were several glacial epochs, alternating with warm inter-glacial periods of long duration. When the cold was at its maximum, the whole area of Finland, Scandinavia, and Scotland, with the North and Baltic seas, was buried under a stupendous sheet of ice, varying from 1000 to 2000 feet in thickness; and this ice-sheet sent off glaciers as far east as Moscow, and as far south as Dresden, while the Alps, the Pyrenees, and the mountains of Auvergne became centres of glaciation, inferior, indeed, to the great northern ice-sheet, but still immense in extent. While the climate of Pleistocene Europe thus came to be similar to that of modern Greenland, parallel phenomena were occurring all over the northern hemisphere. The continent of North America was deeply swathed in ice as far south as the 


\section{EUROPE BEFORE ARRIVAL OF MAN}

latitude of Philadelphia, while glaciers descended into North Carolina. The valleys of the Rocky Mountains supported enormous glaciers, and the same was the case in Asia with the Himalayas. It was during these recurrent periods of arctic cold that the reindeer and musk-sheep found their way to the south of France, while over land-bridges at Gibraltar and Malta the leopard and elephant retreated to Africa. In the intervals between these glacial periods, when the climate became milder than it is at the present day, the arctic mammals travelled northward again, while the lion returned to chase the bison and elk in the forests of Yorkshire.

As the result of these prolonged and repeated climatic vicissitudes, and of the complicated migrations entailed by them, many of the Pliocene mammals still living in Europe at that time have become extinct, - such as the gigantic beaver, the cave-bear, the sabre-toothed lion, five species of deer, three species of elephant, and two of rhinoceros. One race of men - known as the " men of the river drift" - had taken up their abode in Europe when these great changes were beginning, and struggled with the extremes of climate like their enemies, the bears and hyænas. The discovery of flint knives has abundantly proved that man was living near the site of London before the big-nosed rhinoceros had become extinct, and before the arrival of the 


\section{EXCURSIONS OF AN EVOLUTIONIST}

musk-sheep and the marmot in the valley of the Thames heralded the slow approach of the northern ice-sheet. But the fact that human remains of a date even more remote than this have also been found in Portugal and California shows, as I have said already, that man was then no newcomer upon the face of the earth, but must certainly have been in existence for many thousands of years, though as yet we are unable to assign either his primeval habitat or the precise epoch of his first appearance.

Fanuary, 1882. 


\section{II}

\section{THE ARRIVAL OF MAN IN EUROPE}

7 OWARD the close of the Pleistocene age the general outlines of the European continent had assumed very much their present appearance everywhere except in the northwest. The British Islands still remained joined to one another and to the Gaulish mainland, and occupied the greater part of the area of the German Ocean. According to Mr. James Geikie, the connection with Norway again became complete, and the Atlantic ridge was again so far elevated as to bring Scotland into connection with Greenland through the Faroe Islands and Iceland. The whole of Britain stood at an average elevation of from 600 to 1000 feet above its present level. The Thames, Humber, Tyne, and Forth must all have flowed into the Rhine, which emptied itself into the North Sea beyond the latitude of the Shetlands. The glaciers of Europe had retreated within the Arctic Circle, or up to the higher valleys of the great mountain ranges; and the climate was 
EXCURSIONS OF AN EVOLUTIONIST

beginning to assume its present temperate and equable character.

At this remote epoch Europe had already been inhabited by human beings during several thousand years. How long before the beginning of the Pleistocene period man had arrived in Europe is still open to question; but there is no doubt whatever that he lived in Gaul and Britain as a contemporary of the big-nosed rhinoceros, and before the arrival of the arctic mammalia which were driven from the north as the glacial cold set in. This race of man - described by Mr. Boyd Dawkins as the "River-drift Man" - is probably now as extinct as the cave-bear or the mammoth. Late in the Pleistocene period it disappeared from Europe, and was replaced by a new race, coming from the northeast, along with the musk-sheep and reindeer, and called by the same eminent writer the "Cave-Man." Both the Cave-men and River-drift men were in the stage of culture known as the Palæolithic, or Old Stone Age ; that is, they used only stone implements, and these implements were never polished or ground to a fine edge, but were only roughly chipped into shape, and were very rude and irregular in contour. The Palæolithic Age, referring as the phrase does to a stage of culture, and not to any chronological period, is something which has come and gone at very different dates in different parts of the world. It may be 


\section{THE ARRIVAL OF MAN IN EUROPE}

convenient to remember that in northwestern Europe it seems to have very nearly coincided with the Pleistocene period, provided we also bear in mind that the coincidence is purely fortuitous. The implements of the River-drift men, found in Pleistocene river-beds, are very rude, and imply a social condition at least as low as that of the Australian savages of the present day. "They consist," says Mr. Dawkins, "of the flake; the chopper or pebble roughly chipped to an edge on one side; the hâche or ovalpointed implement, intended for use without a handle; an oval or rounded form with a cutting edge all round, which may have been used in a handle; a scraper for preparing skins; and pointed flints used for boring." Man did not then seek for the materials out of which to make these weapons or tools, but " merely fashioned the stones which happened to be within his reach - flint, quartzite, or chert - in the shallows of the rivers, as they were wanted, throwing them away after they had been used." No pottery of any sort has been found in association with these implements, nor were there at that period any domesticated animals. The River-drift men were evidently no tillers of the ground, neither were they herdsmen or shepherds; but they gained a precarious subsistence by hunting the great elk and other deer, and contended with packs of hyænas for the caves which might serve 


\section{EXCURSIONS OF AN EVOLUTIONIST}

for a shelter against the storm. As to what may have been the social organization of these primeval savages, nothing whatever is known. They were a wide-spread race. Their implements have been found, in more or less abundance, in Britain, Germany, France, Spain, Italy, Greece, northern Africa, Palestine, and Hindustan. Their bones have been found in the valleys of the Rhine, the Seine, the Somme, and the Vezère, in sufficient numbers to show that they were a dolichocephalic or long-headed race, with prominent jaws, but no complete skeleton has as yet been discovered.

These River-drift men, as already observed, belonged to the southern fauna which inhabited Europe before the approach of the glacial cold. As the climate of Europe became arctic and temperate by turns, the River-drift men appear to have by turns retreated southward to Italy and Africa, and advanced northward into Britain, along with the leopards, hyænas, and elephants, with which they were contemporary. But after several such migrations they returned no more, but instead of them we find plentiful traces of the Cave-men, - a race apparently more limited in its range, and clearly belonging to a sub-arctic fauna. The bones and implements of the Cave-men are found in association with remains of the reindeer and bison, the arctic fox, the mammoth, and the woolly rhinoceros. They are 


\section{THE ARRIVAL OF MAN IN EUROPE}

found in great abundance in southern and central England, in Belgium, Germany, and Switzerland, and in every part of France; but nowhere as yet have their remains been discovered south of the Alps and Pyrenees. A diligent exploration of the Pleistocene caves of England and France, during the past twenty years, has thrown some light upon their mode of life. Not a trace of pottery has been found anywhere associated with their remains, so that it is quite clear that the Cave-men did not make earthenware vessels. Burnt clay is a peculiarly indestructible material, and where it has once been in existence it is sure to leave plentiful traces of itself. Meat was baked in the caves by contact with hot stones, or roasted before the blazing fire. Fire may have been obtained by friction between two pieces of wood, or between bits of flint and iron pyrites. Clothes were made of the furs of bisons, reindeer, bears, and other animals, rudely sewn together with threads of reindeer sinew. Even long fur gloves were used, and necklaces of shells and of bear's and lion's teeth. The stone tools and weapons were far finer in appearance than those of the River-drift men, though they were still chipped, and not ground. They made borers and saws as well as spears and arrow-heads; and besides these stone implements they used spears and arrows headed with bone, and daggers of reindeer ant- 


\section{EXCURSIONS OF AN EVOLUTIONIST}

ler. The reindeer, which thus supplied them with clothes and weapons, was also slain for food; and, besides, they slew whales and seals on the coast of the Bay of Biscay, and in the rivers they speared salmon, trout, and pike. They also appear to have eaten, as well as to have been eaten by, the cave-lion and cavebear. Many details of their life are preserved to us through their extraordinary taste for engraving and carving. Sketches of reindeer, mammoths, horses, cave-bears, pike, and seals, and hunting scenes have been found by the hundred, incised upon antlers or bones, or sometimes upon stone; and the artistic skill which they show is really astonishing. Most savages can make rude drawings of objects in which they feel a familiar interest, but such drawings are usually excessively grotesque, like a child's attempt to depict a man as a sort of figure eight, with four straight lines standing forth from the lower half to represent the arms and legs. But the Cave-men, with a piece of sharp-pointed flint, would engrave, on a reindeer antler, an outline of a urus so accurately that it can be clearly distinguished from an ox or a bison. And their drawings are remarkable not only for their accuracy, but often equally so for the taste and vigour with which the subject is treated.

Among uncivilized races of men now living, there are none which possess this remarkable $3^{8}$ 


\section{THE ARRIVAL OF MAN IN EUROPE}

artistic talent save the Eskimos; and in this respect there is complete similarity between the Eskimos and the Cave-men. But this is by no means the' only point of agreement between the Eskimos and the Cave-men. Between the sets of tools and weapons used by the one and by the other the agreement is also complete. The stone spears and arrow-heads, the sewing-needles and skin-scrapers, used by the Eskimos are exactly like the similar implements found in the Pleistocene caves of France and England. The necklaces and amulets of cut teeth and the daggers made from antler, show an equally close correspondence. The resemblances are not merely general, but extend so far into details that if modern Eskimo remains were to be put into European caves they would be indistinguishable in appearance from the remains of the Cavemen which are now found there. Now, when these facts are taken in connection with the facts that the Cave-men were an arctic race, and especially that the musk-sheep, which accompanied the advance of the Cave-men into Europe, is now found only in the country of the Eskimos, though its fossil remains are scattered in abundance all along a line stretching from the Pyrenees through Germany, Russia, and Siberia, - when these facts are taken in connection, the opinion of Mr. Dawkins, that the Cave-men were actually identical with the Es- 


\section{EXCURSIONS OF AN EVOLUTIONIST}

kimos, seems highly plausible. Nothing can be more probable than that, in early or middle Pleistocene times, the Eskimos lived all about the Arctic Circle, in Siberia and northern Europe as well as in North America; that during the coldest portions of the Glacial period they found their way as far south as the Pyrenees, along with the rest of the sub-arctic mammalian fauna to which they belonged; and that, as the climate grew warmer again, and vigorous enemies from the south began to press into Europe and compete with them, they gradually fell back to the northward, leaving behind them the innumerable relics of their former presence, which we find in the late Pleistocene caves of France and England. The Eskimos, then, are probably the sole survivors of the Cave-men of the Pleistocene period; among the present people of Europe the Cave-men have left no representatives whatever.

With the passing away of Pleistocene times, further considerable changes occurred in the geography of Europe and in its population. Early in the Recent period the British Islands had become detached from each other and from the continent, and the North Sea and the English and Irish channels had assumed very nearly their present sizes and shapes. The contour of the Mediterranean, also, had become nearly what it is now; and in general such changes as 
have occurred in the physical structure of Europe during the Recent period have been comparatively slight. Of the mammalia living at the beginning of this period, only one species, the Irish elk, has become extinct. The gigantic cave-bear, the cave-lion, the mammoth, and the woolly rhinoceros had all become extinct at the close of the Pleistocene period, and the elephants and hyænas had finally retreated into Africa. In Europe were now to be found the brown and grizzly bear, the elk and reindeer, the wild boar, the urus or wild ox, the wolf and fox, the rabbit and hare, and the badger; and along with these there came those harbingers of the dawn of civilization, - the dog and horse, the domestic ox and pig, with the sheep and goat. A new race of men, also, the tamers and owners of these domestic animals, had appeared on the scene. These new men could build rude huts of oak logs and rough planks, made by splitting the tree-trunks with wedges. Such work was not done with chipped flint-flakes. The men of the early Recent period had the grindstone, and used it to put a fine edge on their stone hatchets and adzes; so that their appearance marks the beginning of a new era in culture. The sharp and accurate edge of the axe, unattainable save by grinding, is the symbol of this new era, which is known to archæologists as the Neolithic, or New Stone Age. 


\section{EXCURSIONS OF AN EVOLUTIONIST}

The huts of the Neolithic farmers and shepherds were built in clusters, and defended by stockades. Wheat and flax were raised, and linen garments were added to those of fur. The distaff and loom, in rude shape, were in use, and grain was pounded in the mortar with a pestle. Rude earthenware vessels were made, sometimes ornamented with patterns. Canoes were also in use. The dead were buried in long barrows, and from the almost constant presence of arrowheads, pottery, or trinkets in these tombs it has been inferred that the Neolithic men had some idea of a future life, and buried these objects for the use of the departed spirits, as is the custom among most savage races at the present time.

The celebrated lake-villages of Switzerland belong to the Neolithic or early Recent period; and the remains of their cattle and of their cultivated seeds and fruits have thrown light upon the origin of the Neolithic civilization. It is certain that the domestic animals did not originate in Europe, but were domesticated in central Asia, which was the home of their wild ancestors; and, moreover, they were not introduced into Europe gradually and one by one, but suddenly and en masse. It is clear, therefore, that they must have been brought in from Asia by the Neolithic men; and the same is true of the four kinds of wheat, two of barley, the millet, 
peas, poppies, apples, pears, plums, and flax, which grew in the gardens and orchards of Neolithic Switzerland.

This rudimentary Neolithic civilization was spread all over Europe, with the exception of the northern parts of Russia and Scandinavia; and there can be no doubt that it lasted for a great many centuries. It certainly lingered in Gaul and Britain long after the valley of the Nile had become the seat of a mighty empire; perhaps even after the Akkadian power had established itself at the mouth of the Euphrates, and " $\mathrm{Ur}$ of the Chaldees" had become a name famous in the world. Still more, it is clear that the Neolithic population has never been swept out of Europe, like the Cave-men and the Riverdrift men who had preceded it, but has remained there, in a certain sense, to this day, and constitutes a very important portion of our own ancestry.

So many skeletons have been obtained of the men and women of the Neolithic period that we can say, with some confidence, that the whole of Europe was inhabited by one homogeneous population, uniform in physical appearance. The stature was small, averaging 5 feet 4 inches for the men, and 4 feet II inches for the women; and the figure was slight. The skulls were "dolichocephalic," or long and narrow; but the jaws were small, the eyebrows and cheek- 


\section{EXCURSIONS OF AN EVOLUTIONIST}

bones were not very prominent, the nose was aquiline, and the general outline of the face oval and probably handsome. In all these points the men of the Neolithic age agree exactly with the Basks of northern Spain, the remnant of a population which at the dawn of history still maintained an independent existence in many parts of Europe. By their conquerors, the Kelts, who led the van of the great Aryan invasion of Europe, these small-statured Basks were known as "Iberians" or "westerners" (Gael. iver, Sanskr. avara, "western"), and "Iberian" is now generally adopted as the name of the race which possessed the whole of Europe in the Neolithic age and until the Aryan invasions, and which still preserves its integrity in the little territory between the Pyrenees and the Bay of Biscay. The Iberian complexion is a dark olive, with black eyes and black hair; so that we may figure to ourselves with some completeness how the prehistoric inhabitants of Europe looked.

It is probable that in Neolithic times this Iberian population was spread not only all over Europe, but also over Africa north of the Desert of Sahara; so that the Moorish and Berber peoples are simply Iberians, with more or less infusion of blood from the Arabs, who conquered them at the end of the seventh century after Christ. And it is also probable that 


\section{THE ARRIVAL OF MAN IN EUROPE}

the Silures of ancient Britain, the Ligurians of southern Gaul and northern Italy, and the rich and powerful Etruskans all belonged to the Iberian race.

In very recent times - probably not more than twenty centuries before Christ - Europe was invaded by a new race of men, coming from central Asia. These were the Aryans, a race tall and massive in stature (the men averaging at least 5 feet 8 inches, and the women 5 feet 3 inches), with "brachycephalic" or round and broad skulls, with powerful jaws and prominent eyebrows, with faces rather square or angular than oval, with fair, ruddy complexions and blue eyes, and red or flaxen hair. Of these, the earliest that came may perhaps have been the Latin tribes, with the Dorians and Ionians; but the first that made their way through western Europe to the shores of the Atlantic were the Gael, or true Kelts. After these came the Kymry; then the Teutons; and finally - in very recent times, near the beginning of the Christian era - the Slavs. These Aryan invaders were further advanced in civilization than the Iberians, who had so long inhabited Europe. They understood the arts which the latter understood, and, besides all this, they had learned how to work metals ; and their invasion of Europe marks the beginning of what archæologists call the Bronze Age, when tools 


\section{EXCURSIONS OF AN EVOLUTIONIST}

and weapons were no longer made of polished stones, but were wrought from an alloy of copper and tin. The great blonde Aryans everywhere overcame the small brunette Iberians, but, instead of one race exterminating or expelling the other, the two races everywhere became commingled in various proportions. In Greece, southern Italy, Spain, and southern France, where the Iberians were most numerous as compared with the Aryan invaders, the people are still mainly small in stature and dark in complexion. In Russia and Scandinavia, where there were very few Iberians, the people show the purity of their Aryan descent in their fair complexion and large stature; while in northern Italy and northern France, in Germany and the British Islands, the Iberian and Aryan statures and complexions are intermingled in endless variety.

We have now carried this brief account of the arrival of man in Europe as far as is requisite for our present purpose. Starting from ages of which only a palæontological record is preserved, we have gradually come down to a period almost within the ken of history. We have seen Europe inhabited in succession by four distinct races of men : first, the men of the River-drift, who belonged to a warm climate, and who during the Glacial period became extinct, along with many of the sub-tropical mam- 
mals with which they were contemporary ; secondly, the Cave-men, who belonged to a cold climate, and of whom the Eskimos are now probably a surviving remnant; thirdly, the swarthy Iberians ; and, fourthly, the fair-skinned Aryans, - these two latest races having by intermarriage given rise to the present mixed population of Europe.

Our next problem is to see how far it may be possible to introduce anything like chronology into this series of events. How long is it since the River-drift men inhabited Europe? Or when did the first Iberians, with their polished stone axes and their herds of cattle, begin to build their rude villages in Switzerland and Gaul? To such questions no very positive answers can be returned. But still we are not left wholly in the dark. A method of inquiry can be pointed out, by following which we may at least come to understand the "orders of magnitudes" in time with which we have to deal. We can substitute partially definite conceptions for wholly vague ones. And we can see how, by following the same line of inquiry with more ample data, it may be possible by and by to introduce something like chronology into the geologic history of the earth's surface.

The so-called "Glacial epoch" here all at once acquires a wonderful interest for us. We 


\section{EXCURSIONS OF AN EVOLUTIONIST}

have seen that it is certain that men inhabited Britain contemporaneously with the big-nosed rhinoceros, which became extinct about the beginning of the Glacial period. How long men lived upon the earth before that time we do not know; but it is clearly established that there were men in Britain then. It would accordingly be very interesting to know when the Glacial period began to come on in Europe. But on this point it has already become possible to form something like a definite opinion.

To understand how we can arrive at a date for the Glacial period, it is necessary first to understand the cause of that wonderful change of climate which allowed all Europe as far south as Dresden, and all America as far south as Philadelphia, to become swathed in an icesheet like that which now covers Greenland. The causes of this event were many and complicated, but the arch-cause - the cause which unlocked all the others and set them going was an astronomical cause. It has been proved by $\mathrm{Mr}$. Croll that the primary cause of the glaciation of the northern hemisphere was a change in the shape of the earth's orbit, such as had occurred before and will occur again; and the dates of these changes in the orbit, whether past or future, can be determined by astronomical methods with great accuracy.

The reason why the weather is warmer in 48 


\section{THE ARRIVAL OF MAN IN EUROPE}

summer than in winter is that in summer the days are longer than the nights, so that the surface of the earth receives more heat in the daytime than it can lose by radiation during the night; while in winter the case is exactly the reverse. Another circumstance tends to make the earth warmer at one time than another, namely, the fact that the earth's orbit is not quite circular, but slightly elliptical or eccentric, so that at one season of the year the earth is nearer to or farther from the sun than at another season. At present the northern hemisphere is nearest the sun in winter and farthest from it in summer, but the difference is only about 3,000 ,$\infty 00$ miles. It must also be remembered that when the earth is near perihelion it moves faster than when it is near aphelion, so that the season when it is nearer the sun is always a little shorter than the season when it is farther from the sun. Thus in our northern hemisphere at present the winter half of the year, or the interval from the autumnal to the vernal equinox, is nearly eight days shorter than the summer half of the year. Thus the difference in length between our summer and winter seasons, and the difference between our distances from the sun at the two extremes of the year, are not great differences, but the advantage, such as it is, is on the side of summer.

But these relations between the earth and the 


\section{EXCURSIONS OF AN EVOLUTIONIST}

sun are perpetually altering. First, owing to the great revolution known as the "precession of the equinoxes," the earth's perihelion 10,500 years ago came in midsummer in the northern hemisphere, and it will come so again 10,500 years hence. In this state of things the winter half of the year was and will be eight days longer than the summer half. Secondly, the shape of the earth's orbit changes from time to time, under the influence of the variously compounded attractions exerted upon it by its companion planets. These changes occur at irregular intervals, but they admit of accurate calculation, and have been computed for 3,000 ,$\infty 00$ years in the past and $1,000,000$ years in the future by $\mathrm{Mr}$. Croll, from formulas furnished by Leverrier. It has thus been ascertained that at three several times within the past $3,000,000$ years the earth's orbit has become very much elongated, so that the difference between its greatest and least distances from the sun has been between four and five times as great as at present, - that is, it has been from $12,000,000$ to $14,000,000$ miles. The first of these periods of high eccentricity began 2,650,000 years ago and lasted 200,000 years; the second began 880,000 years ago, and lasted 180,000 years ; the third began 240 ,000 years ago, and lasted 160,000 years. For the last 50,000 years, the departure of the 


\section{THE ARRIVAL OF MAN IN EUROPE}

earth's orbit from the circular form has been exceptionally small.

Now let us suppose one of these long periods of high eccentricity to coincide with one of the short periods of 10,500 years, when the northern hemisphere has its aphelion in winter; and this, of course, has happened not once only, but a great many times. Under such circumstances, the northern hemisphere is $98,000,000$ miles distant from the sun at midwinter instead of $91,000,000$, as at present, and the winter is twenty-six days longer than the summer instead. of eight days shorter, as at present. On the other hand, at midsummer the sun's distance is only $86,000,000$ miles instead of $94,000,000$, as at present. Now how must this state of things affect the climate of the northern hemisphere?

In the first place, the diminution in the quantity of heat received daily from the sun in winter would be such as to lower the average temperature of the whole northern hemisphere by about $35^{\circ} \mathrm{F}$., so that for example the average January temperature of England, which is now $39^{\circ}$, would fall to $4^{\circ}$. And, conversely, heat enough would be received to raise the mean summer temperature by about $60^{\circ}$ above what it now is.

So far very good, as concerns the amount of heat actually received from the sun. But would 


\section{EXCURSIONS OF AN EVOLUTIONIST}

the summer temperature be raised like this? It would not; and this is because our earth has a means of storing up cold, so to speak, which gives winter the advantage over summer in such a contest. With the mean January temperature of England at $4^{\circ} \mathrm{F}$. instead of $39^{\circ}$, all the moisture which now falls as rain would fall as snow, and would accumulate on the ground. At the coming of summer, all the snow and ice would have to be melted, and it takes a great deal of heat to melt snow and ice. As Mr. Wallace graphically puts it, " to melt a layer of ice only one and a half inch thick would require as much heat as would raise a stratum of air 800 feet thick from the freezing-point to the tropical heat of $88^{\circ} \mathrm{F}$.!" Until the snow is all melted, no amount of solar heat can raise the temperature much above the freezing-point; and this is the reason why, in regions where much moisture is condensed as snow, as in Greenland, and at the summits of the Andes, Alps, and Himalayas, snow is perpetual. So that, in the case we have supposed, the extra heat received from the sun in the short summer would largely be exhausted in melting the snow, and, instead of raising the mean temperature $60^{\circ}$, it is doubtful if it would raise it at all above the point which it attains at the present time. Besides all this, it must be remembered that the rapid melting of great masses of snow produces fog, and thus 
not only obscures the sun's heat, but leads to further heavy condensation in the shape of cold rains. Now bear in mind that this state of things goes on for at least half of the period of 10,500 years, when the aphelion of the northern hemisphere occurs between September and March, and it is easy to see how the snow and ice must so far gain the upper hand that the intense summer heat cannot produce any considerable impression on them, but the region of "eternal snow," no longer confined to the tops of lofty mountains, descends to the sealevel throughout a large part of the northern hemisphere. Thus we get far toward an explanation of the causes of the Glacial epoch. But still other causes have conspired with those here pointed out to enhance the general effect.

While the northern hemisphere was situated as just described, the state of things in the southern hemisphere must have been entirely different. There the perihelion occurring in winter and the aphelion in summer, with the same high eccentricity, the summer would be twenty-six days longer than the winter, and the climatic result would be perpetual spring. And this would affect the flow of ocean-currents in such a way as to deprive the northern hemisphere of its only possible chance of escaping the glaciation we have just depicted. Let us notice this point carefully, for it is one of great importance. 


\section{EXCURSIONS OF AN EVOLUTIONIST}

We have supposed the lowering of the average winter temperature of England, for example, due to the great aphelion distance of the sun, to be $35^{\circ} \mathrm{F}$. There is one way in which this effect might be partially modified, and that is by the equalizing influence of the Gulf Stream. But in the case we have supposed, this influence would almost certainly be cut off. The direction of the main ocean-currents is determined by the trade-winds, and the trade-winds are caused by the difference of temperature between the poles and the equator. As the heated air at the equator rises, the cooler air from north and south flows in to take its place, and these atmospheric currents flowing from the north and south poles toward the equator are what are called the trade-winds. The strength of the trade-winds depends entirely upon the difference in temperature between the equator and the pole; the greater the difference, the stronger the wind. Now, at the present time, the south pole is much colder than the north pole, and the southern trades are consequently much stronger than the northern, so that the neutral zone in which they meet lies some five degrees north of the equator. The trade-winds, pushing stupendous masses of surface oceanwater, produce the main ocean-currents; and accordingly these currents now tend chiefly from south to north, so that most of the heated water 


\section{THE ARRIVAL OF MAN IN EUROPE}

of the central Atlantic, both north and south of the equator, gets carried into the northern temperate zone. In this way the Gulf Stream, coming northward up the west coast of Africa, sweeps across the Atlantic to the easternmost point of Brazil, where part of it gets deflected southward toward the Antarctic Ocean, but most of it flows northwesterly into the Gulf of Mexico, whence it is deflected northeasterly toward the European coast, giving to England its climate of perpetual spring in the latitude of Lab. rador, and tempering the cold of the North Sea even beyond the Arctic Circle. According to Mr. Croll, the quantity of extra heat which the northern hemisphere receives from this source, over and above that which it would get simply from direct solar radiation, amounts to fully one fourth of the latter quantity. But when the aphelion of the northern hemisphere occurred in midwinter, along with a very high eccentricity, all this must have been changed. The tendency of these circumstances, as we have seen, was to make the northern hemisphere very cold, while producing a perpetual spiring in the southern hemisphere. Now, when once the north pole had become colder than the south pole, the northern trades would begin to blow with greater force than the southern, until after a while the neutral line between the two would be shifted south of the equator, and, instead of 


\section{EXCURSIONS OF AN EVOLUTIONIST}

the warm waters of the southern tropical ocean being carried into the northern seas, the case would be just the reverse. The great oceancurrents, instead of all tending northward, as they do to-day, would all tend southward. A very little deflection of this sort would, at the easternmost point of Brazil, turn the whole of the Gulf Stream southward down the coast of South America, and prevent any part of it from flowing up into the North Atlantic, and in this way the progressing refrigeration of Europe and North America would be most powerfully enhanced.

Thus, when the eccentricity of the earth's orbit was three or four times as great as at present, and during the period when aphelion in the northern hemisphere occurred in the winter season between September and March, the tendency must have been toward perpetual snow and ice over a large part of the northern hemisphere, and toward perpetual spring throughout the southern hemisphere. But when winter aphelion occurred in the southern hemisphere, then every thing was reversed; then the tendency south of the equator was toward glaciation, and north of the equator it was toward perpetual spring. In Europe you would have, for 10,500 years, a period during which the climate would gradually become more and more arctic for 5250 years, thenceforward 


\section{THE ARRIVAL OF MAN IN EUROPE}

gradually becoming less severe; and upon this would ensue another period of 10,500 years, during which the climate would grow more and more equable for 5250 years, thenceforward gradually increasing again the differences between summer and winter; and in a period of 160,000 years such 21,000-year cycles would naturally occur nearly eight times. So that, upon a geological survey of what is called the Glacial epoch, we might expect to find an alternation of severe and mild climates in Europe, - an alternation of epochs in which Britain was inhabited by the hippopotamus with epochs in which the reindeer roamed to the south of France. And this is, in fact, what we do find. It is not long since the Glacial period in Europe was supposed to have been one long, monotonous period of extreme cold; but now the foremost geologists - such as Mr. James Geikie, who has more than any one else illustrated this subject - have discovered at least four or five alternations of warm and cold periods in Europe during the Glacial epoch; and with further and more minute research we may expect the agreement between observation and deduction to become still more convincing.

Enough has now been said to give the reader some idea of the magnificent line of reasoning by which Mr. Croll has unfolded the causes of the Glacial period. And it also becomes appar- 


\section{EXCURSIONS OF AN EVOLUTIONIST}

ent at once why we must probably select the latest period of high eccentricity in the earth's orbit as the period for which we have been seeking. For that period - which began 240,000 years ago, and terminated 80,000 years ago presented such a set of astronomical circumstances as must have resulted in the repeated glaciation of the northern hemisphere, after the manner above described. And the antiquity of that period seems to be sufficiently great to allow for the geological changes which have occurred since the Pleistocene age. If we were to assign an earlier epoch of high eccentricity for the Glacial period, it would then become necessary to show why, with the present relations of land and sea on the globe, the latest epoch of high eccentricity should not have produced a subsequent glacial period. But the Glacial period which Agassiz first taught us to understand, and which in recent years has been made the subject of such minute study, is clearly the latest glacial period that has occurred in the northern hemisphere; for it is the one of which the traces are now everywhere around us; it is the one which has carved the mountains of Scotland and New England in their present beautiful outlines, and covered their sides with boulders, and filled the valleys with romantic tarns or magnificent lakes. If we adopt $\mathrm{Mr}$. Croll's theory of the causes of glaciation, we 


\section{THE ARRIVAL OF MAN IN EUROPE}

are clearly bound to look to the latest rather than to any earlier manifestation of those causes, in order to account for that glacial period the effects of which are still visible all around us. Accordingly, among the foremost geologists who have adopted Mr. Croll's conclusions, there has been a general agreement that the period of high eccentricity which began 240,000 years ago and ended 80,000 years ago must have been coincident with the great period of glaciation which occurred during the Pleistocene age in Europe and America.

The most serious objection that has been urged against Mr. Croll's theory is that it seems to require us to suppose that there have been recurrent glacial epochs, at irregular intervals, during the whole past duration of the earth's history. And in particular it would seem to be implied that there must have been a great glacial period from 880,000 to 700,000 years ago, and another one from $2,650,000$ to $2,450,000$ years ago, both of these dates being long subsequent to the beginning of the Tertiary period. Mr. Croll has sought to meet these objections by showing that such must really have been the case. He alleges evidence of glaciation in every one of the geological periods back to the Cambrian, with the single exception of the Triassic. And he argues, in particular, that the epoch of high eccentricity which 


\section{EXCURSIONS OF AN EVOLUTIONIST}

began 880,000 years ago corresponded with a glacial epoch in the Miocene period, and that in like manner the date of 2,650,000 years ago witnessed the beginning of a great glacial epoch in the Eocene period. But these conclusions are not generally adopted by geologists. There are some evidences of local glaciation in the Miocene period in the neighbourhood of the Alps, which were probably higher then than they are at present, but the weight of evidence is entirely in favour of the conclusion that the general climate of Europe throughout the Eocene and Miocene periods was much warmer than it has been at any later date. From the Eocene period down to the Pleistocene, there can be little doubt that there was a slow but steady lowering of the mean temperature of Europe, until in the latter period there occurred that comparatively rapid refrigeration which brought about a glacial epoch. In earlier than Tertiary times, on the other hand, Mr. Croll seems to have been more successful. There are distinct and numerous evidences of extensive glaciation in Europe during the remote Permian period; and it is not improbable that similar phenomena may have taken place in Silurian times. On the whole, however, it does not seem likely that there have been many periods of extreme glaciation, like that which we suppose to have ended about 80,000 years ago; and it is quite unlikely that 


\section{THE ARRIVAL OF MAN IN EUROPE}

there has been any other such period since the beginning of Tertiary times. How, then, shall we explain the occurrence of two periods of high eccentricity, one lasting 200,000 and the other 180,000 years, without an accompanying glaciation of the northern hemisphere?

This difficulty has been sometimes cited as fatal to Mr. Croll's theory; but when we fully consider all the conditions of the case, we shall see that it is not so. For we must remember that it is not simply the cold, but it is the snow of the glacial winter, that chills the summers and renders possible the accumulation of ice. To produce a glacial epoch, according to Mr. Croll's theory, it is not enough that the mean winter temperature of the northern hemisphere should be lowered $35^{\circ} \mathrm{F}$., unless there is enough condensation of moisture going on to produce an abundant snowfall. Under such geographical conditions as exist to-day, and as existed during the Pleistocene period, there would be such a condensation and such a snowfall; but in the Eocene and Miocene periods it was probably otherwise. The explanation is not difficult.

The most efficient promoters of condensation are mountains, which, thrusting their cold summits high into the air, precipitate the surrounding moisture. It is a familiar fact that mountainous districts are apt to be rainy, and that very high mountains are usually covered with snow 


\section{EXCURSIONS OF AN EVOLUTIONIST}

in midsummer, even while oranges and palms are flourishing a few thousand feet below. It is not quite so familiar a fact that no intensity of arctic cold will suffice to prevent a warm or mild summer unless there is an extensive deposit of snow in the winter. Now, nowhere on the earth do we find any lowlands of great extent covered with perpetual snow. The coldest winters on the globe occur in eastern Siberia, where the temperature often averages $-40^{\circ} \mathrm{F}$. for several weeks in succession, and, according to Professor Pumpelly, sometimes sinks to - $120^{\circ} \mathrm{F}$.! Yet so dry is the atmosphere that but little snow falls, and after this has been melted in the spring the weather rapidly grows warm. "At Yakutsk, in 62 degrees $N$. latitude, the thermometer stands often at $77^{\circ}$ in the shade, and wheat and rye produce from fifteen to forty fold," while the prairies are covered with grass and flowers. As Mr. Wallace observes, " it is only where there are lofty mountains or plateaus - as in Greenland, Spitzbergen, and Grinnell Land - that glaciers, accompanied by perpetual snow, cover the country, and descend in places to the level of the sea." The coast of the Antarctic Continent is girded with lofty mountains, which effect such condensation in the damp sea-air about them that the continent is buried under a mass of ice more than a mile in thickness. The antarctic islands South Georgia and South Shetland "are very moun- 


\section{THE ARRIVAL OF MAN IN EUROPE}

tainous, and send down glaciers into the sea ; and as they are exposed to moist sea-air on every side, the precipitation, almost all of which takes the form of snow even in summer, is of course unusually large."

In order, therefore, to get a centre from which to start an accumulation of snow and ice sufficient to bring on a glacial epoch in the northern hemisphere, it would seem absolutely necessary that there should be a considerable amount of high land within the Arctic Circle. But in the Eocene and Miocene periods this condition does not seem to have been satisfied. Throughout the greater part of these two periods the area within the Arctic Circle was less elevated than it has been ever since the beginning of the Pliocene age. Greenland stood lower than at present, and the greater part of Siberia was submerged. Moreover, as already stated in the preceding paper, the continents of Europe and Asia did not become " united into one unbroken mass" until the Pliocene period. In the earlier Tertiary times the warm waters of the Indian Ocean flowed northwestward between Asia and Europe even into the Arctic Ocean, the mountains of Armenia and the Caucasus protruding as islands from this vast sea surface. Again, Mr. Wallace has pointed out a number of peculiarities in the distribution of plants and animals in the southern hemisphere which " render it almost certain" 


\section{EXCURSIONS OF AN EVOLUTIONIST}

that in the early Tertiary times the antarctic land was much more extensive than at present. Now an elevation in the antarctic region, increasing the deposit of snow and ice about the south pole, and thus increasing the difference of temperature between the south pole and the equator, would be just what was needed to convert the fickle monsoons of the Indian Ocean into a steady and powerful trade-wind, that would drive the warm water northward through the channel between Europe and Asia, even as far as the north pole. This current from the Indian Ocean must have been more than equal to the Gulf Stream in heating power, and its effect would be to prevent any accumulation of ice within the Arctic Circle, and to produce in Greenland such a climate as it is known to have enjoyed in the Miocene period, when it was covered with a vegetation as luxuriant as that of Virginia at the present day.

This question is discussed at considerable length and with great ability by Mr. Wallace, in his treatise on "Island Life." His argument is in some respects the most valuable contribution that has ever been made to our understanding of past climatic changes. He makes it perfectly clear that while Mr. Croll's astronomical interpretation of the Glacial period is perfectly correct in principle, nevertheless extensive glaciation cannot take place unless the geographi64 


\section{THE ARRIVAL OF MAN IN EUROPE}

cal conditions are such as to enable a great accumulation of ice to begin. We are not, therefore, obliged, on Mr. Croll's view, to suppose that every epoch of high eccentricity has inaugurated a glacial period; and we see, in particular, why such a result was not likely to follow $2,650,000$ years ago or 800,000 years ago, supposing the latter date to have occurred before the beginning of the Pliocene age; and thus the only serious objection to Mr. Croll's theory is effectually disposed of.

We have every reason to believe, then, that the great Glacial period of the Pleistocene age began 240,000 years ago, and came to an end 80,000 years ago. But at the beginning of this period men were living in the valley of the Thames; at the end of it the men of the Riverdrift had probably become extinct, and their place in Europe had been taken and held for ages by the boreal Cave-men, who now in turn were about starting on their long retreat to the arctic regions. How long a time may have elapsed before the swarthy Iberian settled in Europe, with his dogs and cattle, we have no means of deciding; nor can we say when the blue-eyed Aryan began his invasions, though we know that this last event must have been very recent, - not very long before the dawn of history. Nor can we tell how long there had been human beings on the earth before the Glacial epoch began. But, 


\section{EXCURSIONS OF AN EVOLUTIONIST}

as I have said already, it must have been a great while, because, even before the close of the Pliocene age, they had had time to spread over the earth as far as Portugal in one direction, and as far as California in the other. And if we are to take the date of 240,000 years ago for the beginning of the Glacial epoch, we can hardly allow for the close of the Pliocene age an antiquity of less than 400,000 years.

It only remains to add that the enormous length of time during which the human race has existed is of itself a powerful argument in favour of the opinion - now generally accepted - that the human race was originated, by a slow process of development, from a race of non-human primates, similar to the anthropoid apes. We see man living on the earth for perhaps half a million years, to all intents and purposes dumb, leaving none but a geological record of his existence, progressing with infinite slowness and difficulty, making no history. Yet his geologic record is not quite like that of the dog or the ape, who could not chip a flint, and in the incised antlers of the Cave-men we see the first faint gleams of the divine intelligence that was by and by to shine forth with the glories of a Michael Angelo. We cannot but suppose that during those long dumb ages, through infinite hardship and through the stern regimen of deadly competition and natural selection, man was slowly but 


\section{THE ARRIVAL OF MAN IN EUROPE}

surely acquiring that intellectual life which was at last to bloom forth in history, and which has made him "the crown and glory of the universe."

$$
\text { Fanuary, } 1882 .
$$




\section{III}

\section{OUR ARYAN FOREFATHERS}

T $N$ the beginning of the Vendidad, or first of the Parsi collection of sacred books 1 known as the Zendavesta, we are told that the supreme deity Ahura-Mazda created a country full of delights, but difficult of access, and the name of this country was Aryana Vaejjo. So charming was this primitive country that, had it not been made difficult of approach, the whole animate creation would have flocked thither and quite overwhelmed it. But this state of things did not long continue; for Ahriman, or Anramainyus, the spirit of darkness, was the implacable adversary of Ormuzd, or Ahura-Mazda, the spirit of light, and took pleasure in spoiling all his creations. So this death-dealing enemy, with the aid of his daevas, or demons, created a great serpent and brought ten months of winter cold upon the land, so that Aryana Vaejo was no longer a comfortable dwelling-place. The good spirit then created a new home for his people, called Sugdha; but the adversary spoiled this by creating a kind of wasp which devastated the fields and brought death to the 


\section{OUR ARYAN FOREFATHERS}

cattle. Then Ahura-Mazda made a third habitat, which was called the high and holy Muru; but the dark demon now whispered evil reports and stirred up strife, until here, too, life became unendurable, and the beautiful land of Bakhdhi, or Baktria, was created as a fourth home for the children of light. So the warfare went on, until no less than sixteen countries are enumerated as successively created and made uncomfortable. In the last region of all the complaint is again of cold weather and hoar-frost; but perhaps in comparison with all the other plagues this now seemed endurable. At all events, the account here ends, with the admission that there are also other regions and places besides those described; as much as to say that we are not here concerned with the history of all mankind, but only with the worshippers of Ahura-Mazda.

The book from which this legend is cited is one of the oldest in the literature of the world. It belongs to a more primitive age than the Homeric poems, and may probably be regarded as contemporary with the oldest hymns of the Veda. Written not in the court language of ancient Persia, but in the closely related archaic dialect of Baktria, - very much as the ecclesiastical services of Russia to-day are written in Old Bulgarian, - the Zendavesta was, in the time of Darius Hystaspes, the sacred book of the most prominent nation in the world. For eleven 
hundred years afterward the worship of AhuraMazda retained its ascendency in the countries between Euphrates and the Indus, until in the seventh century after Christ this whole region was overrun by Mohammedans, and converted to their faith. For a long time, no doubt, the Magian religion continued to survive alongside of Islam, as we see from the frequent allusions to "fire-worshippers " in the "Arabian Nights," where they are indeed most abominably slandered. But after a while the good AhuraMazda, yielding to this last and gravest mischief wrought by the adversary, devised yet another abode for the remnant of his people, and led them to Bombay and its neighbourhood, where, under the name of "Parsis," or "Persians," they still keep up their old ceremonies and their old faith.

The legend of the sixteen countries created by the good spirit was regarded by Bunsen as a historical tradition of the migrations by which the ancestors of the Indo-Persians reached the countries where, at the beginning of authentic history, we find their descendants. But it will not do to attach too much historical value to legends like this. For, however venerable may be the record, the very mist of antiquity which shrouds it prevents us from knowing how or whence it got the information which it imparts. The story before us, indeed, has neither the 


\section{OUR ARYAN FOREFATHERS}

pretensions nor the credentials of an authentic historical narrative. It relates long-past events as ascertained not through the sifting of previous human testimony, but by direct revelation from the good spirit to his prophet Zarathustra or Zoroaster. Nevertheless, the geographical succession of the various places mentioned in this legend is very suggestive. With the exception of Aryana Vaejjo, every one of the sixteen abodes seems to be described by a genuine geographical name, though two or three have not yet been satisfactorily determined. Thus Sugdha, the second country, is what the ancients knew as Sogdiana; Muru appears to be the modern Merv, or Margiana; and Baktria, the next in order, has been already mentioned. And so, curiously enough, by stringing together the whole series of names, there is indicated a continuous migration from the region beyond the Oxus, at first southwesterly, and then southeasterly, down to what we now call the Punjab, or " country of five rivers," but which in the Vedic hymns is somewhat more comprehensively termed the Sapta-Sindhavas, or "Seven Rivers," and which in our Zend legend is described in identical language as the Hapta Hendu. This larger designation is reached by including, along with the five rivers of the Punjab, the Sarasvati and the Indus, or "The River," par excellence. Having thus reached 


\section{EXCURSIONS OF AN EVOLUTIONIST}

the northwestern confines of Hindustan, in the fifteenth country created by Ahura-Mazda, the legend here informs us that Anramainyus devised "untimely evils and unbearable heat;" and thereupon we are abruptly transported, in the sixteenth region, to the cool neighbourhood of the Caspian Sea, perhaps the country of the Medes.

Now, however difficult it may be to accept such an account as properly historical, the course of migration here indicated is so thoroughly in accordance with all that we know of the relations between the peoples of the Persian Empire and the dominant race of Hindus in India that it is hard not to grant to it some traditionary value. It would appear, at least, that when the Vendidad was composed the worshippers of AhuraMazda must have believed that their ancestors came from somewhere beyond the Oxus, and travelled in the direction of Hindustan, until something occurred which turned them westward again. This would seem to be the only sound meaning that can be extracted from the legend. But this is in wonderful accordance with the results of modern critical inquiry. From a minute survey of the languages and legends of this whole region, it has been well established that the dominant race in ancient Persia and in ancient India was one and the same; that it approached India from the north- 


\section{OUR ARYAN FOREFATHERS}

west; and that a great religious schism was accompanied by the westward migration of a large part of the community, while the other part proceeded onward, and established itself in Hindustan. A comparison of the Zendavesta with the Veda - so strongly alike as they are, both in thought and in expression - shows clearly that the occasion of this schism must have been the promulgation of the worship of AhuraMazda.

In illustration of this community of origin between the Vedic and Zendavestan peoples, let us refer to the name of the first country which the supreme deity created, - the name of Aryana Vaejo. This, as already hinted, is not a geographical name. There is no identifiable locality which has ever been called Aryana Vaejo. The name means simply "the starting-place of the Aryans." In later Persian mythology, as represented in the Minokhired, the name came to stand for a terrestrial paradise, where men live for three hundred years, without pain or sickness, where no lies are told, and where ten men eat of one loaf and grow fat thereon. In the Vendidad, however, Aryana Vaejo is simply the primeval dwelling-place, whatever it may have been, from which the Aryans passed into Sogdiana. Now "Aryan" wras the name by which the ancient Persians and the ancient Hindus alike described themselves. 


\section{EXCURSIONS OF AN EVOLUTIONIST}

In the Vedic hymns the dominant people of India habitually speak of themselves as Aryans, in contrast with the Dasyus, or inferior races of Hindustan, whom they had subdued. Just in the same way Darius Hystaspes, in the inscription upon his tomb, declares himself to be an Aryan, of Aryan descent. The Medes are always called Aryans by Armenian writers ; and Herodotos was also familiar with this appellation. In a more special sense the countries between India and Persia, now known as Afghanistan and Cabul, were known throughout classic antiquity as Ariana. Along with this community of name there was close community of speech among these peoples. The court language of the Medes and Persians, as preserved in the cuneiform inscriptions of Darius, the Zend or Baktrian language, in which the sacred books of Zarathustra are written, and the Sanskrit of the Vedic hymns are as clearly dialects of the same parental language as French, Spanish, and Italian are dialects of Latin. These outline facts are all that we need for the present to show how Aryan was the common name for a race which, advancing from the north, acquired supremacy over all the country between the Euphrates and the mouth of the Ganges. Whence these people originally came it would be idle to inquire, but we may fairly conclude that they first attained to something like world- 


\section{OUR ARYAN FOREFATHERS}

historic importance in the highlands of central Asia, somewhere about the sources of the Oxus and the Jaxartes; and this region we regard as "Aryana Vaejo," or the most aboriginal spot to which we are able to trace the Aryan people.

We have next to inquire into the meaning of the word Aryan; and this is not a difficult matter, or one about which there is much question. In Sanskrit the word arya, with a short initial $a$, is applied to cultivators of the soil, and it would seem to be connected etymologically with the Latin arare and the archaic English ear, "to plow." As men who had risen to an agricultural stage of civilization, the Aryans might no doubt fairly contrast themselves with their nomadic Turanian neighbours, who - as Huns, Tatars, and Turks - have at different times disturbed the Indo-European world. But for the real source of the word, as applied to the race, we must look further. This word arya, " a cultivator of the soil," came naturally enough in Sanskrit to mean a householder or land-owner, and hence it is not strange that we find it reoccurring, with a long initial $a$, as an adjective, meaning " noble" or " of good family." As a national appellative, whether in Sanskrit or Zend, this initial $a$ is always long, and there can be no doubt that the Aryans gave themselves this title as being the noble, aristocratic, or ruling race, in contradistinction to the aboriginal 


\section{EXCURSIONS OF AN EVOLUTIONIST}

races which they brought into servitude. In this sense of noble, the word frequently occurs in the composition of Persian proper names, such as Ariobarzanes, Ariaramnes, and Ariarathes; just as in old English we have the equivalent word ethel, or noble, in such names as Ethelwolf and Ethelred. As an ethnic name, therefore, the word Aryan seems to have a tinge of patriotic or clannish self-satisfaction about it. But we shall find, I think, that such a shade of meaning has been more than justified by history; for we have now reached a point where we may profitably enlarge the scope of our discussion, and show how the term Aryan is properly applicable, not merely over an Indo-Persian, but over an Indo-European area, comprehending the most dominant races known to history, the Greeks and Romans, Slavs and Teutons, with the highly composite English, whose language and civilization are now spreading themselves with unexampled rapidity over all the hitherto unoccupied regions of the earth, which the Vendidad did not care or did not know how to specify. In order to explain in what sense we may all properly be called Aryans, we must consider for a moment some of the striking results which have been obtained, within the present century, from the comparative study of languages.

No event of modern times has exerted a 76 
more profound and manifold influence upon the intellectual culture of mankind than the English conquest of India. The enlargement of our mental horizon which has resulted therefrom is not less remarkable than that which attended the revival of Greek studies in the fifteenth century. It is not simply that observation of India is making us acquainted with an enormous multitude of primitive social, linguistic, and religious phenomena which formerly were hidden from our notice. In contemplating these phenomena, we have become possessed of a method of study which has already wrought such wonders as to vie with the ointment of the Arabian dervise, that enabled its owner to detect all the buried treasures of the earth. This mighty talisman is the Comparative Method, or the attempt to interpret a fact by comparing it with a series of similar facts, which different circumstances have caused to vary in different degrees. I do not mean to imply that mankind have not always used this method more or less, both in matters of science and in matters of every-day life. Nor do I mean to claim for modern philology any exclusive title to the honour of having shown what can be done by studying phenomena in this way. I do not forget that the classification of living and extinct animals by Cuvier, with reference to palæontological epochs, was a gigantic act of compari- 


\section{EXCURSIONS OF AN EVOLUTIONIST}

son, which first made it possible for us to understand the past history of life on our globe. It is none the less true not only that systematic employment of the comparative method on an extensive scale is the most notable philosophic achievement of the nineteenth century, but also that its first great triumph was the establishment of the Aryan, or Indo-European, family of languages. This triumph was prepared by the study of Sanskrit, which ensued upon the English conquest of India. Previous to this, indeed, the close resemblance between Greek and Latin had been often enough remarked, and theories had been entertained concerning a primeval kinship between the peoples of Greece and Italy. But in the case of peoples so similar in aspect and so closely connected with one another from time immemorial, this similarity of speech did not provoke much curiosity. It was quite otherwise when a language unmistakably akin to Greek and Latin, both in grammar and vocabulary, was discovered in such an out of the way country as Hindustan, and among a people who had hitherto been generally supposed to be barbarians. The discovery was emphasized by the fact that no such obvious resemblances existed in Hebrew, a language much nearer geographically and historically, and from which there had been no end of futile attempts to derive Latin and Greek. Further interest was excited when 


\section{OUR ARYAN FOREFATHERS}

it became known that this newly found language contained an enormous mass of literature alleged to be the oldest in the world. All things thus combined to stimulate speculation as to the true character of the relationship between Sanskrit and the languages of Greece and Rome. This relationship was not one of parentage. It has been a common popular error to suppose that Latin and Greek are derived from Sanskrit; but from the first no such view was countenanced by competent scholars. About 1790, Sir William Jones declared his opinion that the three languages were sprung from "some common source, which perhaps no longer exists." Persian also he was inclined to attribute to the same source, and he hinted at the possibility that Gothic and Keltic might be included in the group. This was coming very near to the conception of an IndoEuropean family of languages. But that conception was not clearly formed until nearly twenty years later, and then it was reached not by a great philological scholar, but by a poet and literary critic. In 1808 , Friedrich Schlegel maintained that the languages of India, Persia, Greece, Italy, and Germany were connected by common descent from an extinct language, just as the modern Romanic languages are connected by common descent from Latin; and for the whole family he proposed the name Indo-Germanic. The correctness of this view was demonstrated 


\section{EXCURSIONS OF AN EVOLUTIONIST}

by Bopp, in his "Comparative Grammar," published from 1833 to 1852 , in which the Zend, Armenian, Slavonic, and Lithuanian languages also were added to the group. The Keltic languages were included about the same time, and the name Indo-Germanic was extended to IndoEuropean. Within the last fifteen years mainly through the influence of Max Müller's writings - the name Aryan has come into general use as the most convenient designation of the whole family. The use of the word in this extensive sense has indeed been objected to by Professor Whitney and others, who urge that it is properly applicable only to the Indo-Persian branch of the family; and in strictness their argument seems to be sound enough. There is no evidence that any of the European peoples have ever called themselves Aryans, and the traces of the name which Müller has sought to point out in Europe are very scanty and obscure. According to Stephanus of Byzantium, Aria was an old name for Thrace, and among the ancient Germans we find a tribe of Arii and such proper names as Ariovistus; but it is by no means certain that these names are in any way connected with the original Arya. Nor did Pictet meet with any better success in his attempt to find Arya in the name of Erin or Ireland, the home of the Eri, or Irish. This modern name is a contracted form. Its root in old 
Keltic seems to have been Iver, which is the same as the Sanskrit avara, "western." It appears in the Latin Avernus, a famous lake on the west coast of Italy, as well as in Ivernia, or Hibernia, the western island. This old word Iver has been shortened to $I r$ or $E r$, and out of this, by putting on their own terminations, the English have made Ire-land, the home of the Ir-ish, or "Westerners." But in spite of the fact that we find no certain traces of the name Aryan in the European languages, I believe that the modern use of the word, as descriptive of the whole family, is likely to prevail. It is a much less cumbrous term than "IndoEuropean," and, while it is advantageously free from geographical restrictions, it emphasizes, at the same time, the fundamental fact that the Aryana Vaëjo, or prehistoric starting-point of the eastern members of the family, was also the starting-point of the western members. It implies - what every one admits to be true - that the dominant race in Europe came from central Asia. And, still further, it serves admirably as a name for the extinct mother tongue from which all the Indo-European languages have descended. By many scholars this primitive tongue is itself called Indo-European; but I am unable to see any propriety in giving such a name to a language which, as being confessedly spoken north of the Oxus and east of the 


\section{EXCURSIONS OF AN EVOLUTIONIST}

Caspian, was certainly neither Indian nor European in any sense. It seems to me much better, and more in conformity to the general style of philologists, to call this ancestral language "Old Aryan," just as we say "Old Norse" for the primitive form of Danish, Swedish, and Norwegian.

As we now proceed to take a brief survey of the Aryan domain, I think we shall realize the advantage of having a word that is independent of geographical limits. The Aryana of the present day is much more than an Indo-European region. Its eastern boundaries have altered but little for many centuries; but on the west it has extended to the Pacific coast of America, and on the other side of the world it has begun to annex territory in South Africa and Australia. Indeed, if we are to judge from what has been going on since the times of Drake and Frobisher, it seems in every way likely that men of English speech will by and by have seized upon every part of the earth's surface not already covered by a well-established civilization, and will have converted them all into Aryan countries. But our linguistic term Aryan is independent of such changes. Since prehistoric times eight principal divisions of Aryan speech have existed, but these groups of languages have had very different careers, and some of them are rapidly becoming extinct. The first great separation of 
Aryan tribes was the separation between the invaders of Indo-Persia and the invaders of Europe. We have already observed how the language of the Indo-Persians became divided in twain. In the Indic class of languages, comprising the classical Sanskrit, the Prakrit of later dramatic writers, the $\mathrm{Pali}$, or sacred language of the Buddhists in Ceylon, and some twenty modern dialects spoken chiefly in the northern half of Hindustan, we have the first grand division of Aryan speech. The second or Iranic class comprehends the Zend, the ancient Persian of the cuneiform inscriptions, the Parsi of Bombay, the Pushtu of Afghanistan, modern Persian, Armenian, Kurdish, and the Ossetian spoken in the Caucasus. Concerning these two grand divisions, we need only observe that the extremely close resemblance between Sanskrit and Zend would seem to indicate that the separation of the two occurred at a comparatively late date, though it would perhaps be difficult to suppose it later than two thousand years before Christ. It may have been a little before this that the western tribes of Aryans crossed the Volga and began the conquest of Europe. First appear to have come the Kelts, whose languages constitute the third great division. These languages diverge considerably from the common type, and were the latest to be recognized as Aryan in character, - a fact which is quite in harmony 
with the opinion that they were the first to branch off from the original stock. The Kelts have always been an important race, but their languages have not thriven in the world. Keltic geographical names are scattered all over Europe, and in the eastern part such words as Dnieper, Don, and Danube testify to the former presence of the language in which don was a common name for water or river. The Kelts formed a large part of the populations of Spain and northern Italy, and a principal part of the populations of Gaul and Britain, when these countries were subjected to Roman dominion; and as late as the Christian era they were to be found in large numbers as far east as Bohemia. Since then they have been partly conquered and partly driven westward by Romans and Teutons, without ceasing to be conspicuous as a race ; but their languages have sunk into comparative obscurity, and are fast disappearing. The Gauls, who showed such a remarkable aptitude for taking on the manners of their conquerors that by the fourth century their country was almost as thoroughly Romanized as Italy itself, forgot their own language with wonderful ease. It was so completely trampled out by Latin that very scanty vestiges remain to show what it was, if we except geographical names. At the present day two groups of Keltic languages remain: the Gaelic, still spoken in 


\section{OUR ARYAN FOREFATHERS}

Scotland, Ireland, and the Isle of Man; and the Kymric, or old British, which survives in Welsh and in the dialect of Brittany. A third dialect of Kymric was formerly spoken in Cornwall, but it died in 1770 with Dame Dolly Dentreath.

Concerning the fourth and fifth grand divisions of Aryan speech - the Italic and Hellenic - but little need be said. These languages are too illustrious to stand in need of much description. The relationship between them is closer than in the case of any other Aryan languages of different class, save the Zend and Sanskrit; and this close resemblance justifies the inference that the separation between Greeks and Italians was comparatively recent. They would appear to have entered Europe somewhat later than the Kelts, but everything connected with their prehistoric career is extremely problematical. To the Hellenic class belong only two languages, - the uncultivated Albanian and the Greek, which was stereotyped so early and so thoroughly by literary culture that to the Athenian schoolboy of to-day the history of Herodotos can hardly seem written in a foreign tongue. To the Italic class belong the ancient Umbrian and Oscan and the Latin, which still survives under the variously modified forms of Italian, French, Provençal, Spanish, Portuguese, Rumansch, and 


\section{EXCURSIONS OF AN EVOLUTIONIST}

Wallachian. To the linguist the history of these Romanic dialects is peculiarly valuable, as illustrating, with the aid of plentiful documents, a process of divergence somewhat similar to that which previously broke up the Old Aryan into different languages.

The Teutons, whose languages form our sixth grand division, seem to have entered Europe after the tribes already mentioned. About Cæsar's time we find Teutons driving Kelts out of Germany, and threatening to overrun Gaul; but during most of classic antiquity the centre of Teutonism seems to have been farther east than Germany. The greater part of what is now European Turkey was occupied by Goths in the time of Herodotos, and for eight centuries afterwards. The ancient Thracians were Goths, according to Grimm, and so were the Getæ. And since the Christian era Teutonic tribes appeared in what is now southern Russia. The terrible irruption of non-Aryan Huns from Asia, in the fifth century, drove these tribes westward, and brought them into collision with the Empire. Of the Gothic language nothing remains save a portion of a translation of the Bible, made by Ulfilas in the fourth century. The other branches of Teutonic speech - Scandinavian, High German, and Low German, of which our own English is the most important dialect are too well known to require comment. 


\section{OUR ARYAN FOREFATHERS}

The seventh and eighth grand divisions of $\mathrm{Ar}$ yan language are the closely related Lettic and Slavonic. The Lettic languages, like the Keltic, are fast dying out. Of Old Prussian, which has been dead for two centuries, nothing is now left save the Catechism of Albert of Brandenburg. Lettish and Lithuanian, of which the latter is remarkable for its strong resemblance to Sanskrit, are still spoken in the Baltic provinces of Russia.

As for the Slavs, they appear in history north of the Black Sea about the time of Trajan, and begin to be frequently mentioned in the sixth century. Since then they have pushed westward far into the Teutonic domain, but have nowhere, save in Russia, retained political independence. Of the fifteen or more Slavonic languages, the old Bulgarian and the modern Russian, Polish, Bohemian, Croatian, and Serbian are of most importance.

Looking thus over our modern linguistic Aryana, we see that in the Old World it pretty nearly covers the geographical area included between the Ganges and the Atlantic Ocean. Small regions of non-Aryan speech, however, occur here and there within this area, and a brief glance at these will serve to increase the definiteness of our knowledge.

Wherever non-Aryan languages are spoken within this Indo-European domain, it is for 87 


\section{EXCURSIONS OF AN EVOLUTIONIST}

either one of two reasons. Such languages are spoken either by descendants of the aboriginal tribes, whom the invading Aryans overcame, o* $^{*}$ by descendants of non-Aryan invaders, who have pushed in at a later date, and secured for themselves a lodgment upon Aryan soil. Of the first class we find a few sporadic instances. The language variously called the Bask, Euskarian, or Iberian, now spoken in the Asturias and about the Pyrenees, has no similarity whatever to the Aryan languages. It is spoken by the scanty remnant of a people who in immemorial antiquity seem to have been spread all over western Europe, but who were for the most part conquered and absorbed by the Keltic van of the Aryan invasion. The case may have been similar with the Iapygian and Etruskan, which were long ago trampled out in Italy by the Latin; but on this obscure point I would hardly venture an opinion. In northern Europe, Finnish, Esthonian, and Lappish are still spoken by races pushed into the corner by Teutons and Slavs. A perfect Babel of aboriginal dialects still exists in the inaccessible fastnesses of the Caucasus; and many of the highlands of India similarly shelter primitive non-Aryan tribes, whose forefathers refused to submit to Brahmanic oppression. It is a characteristic of such remnants of conquered speech to subsist only in out of the way or undesirable corners. On the other hand, 


\section{OUR ARYAN FOREFATHERS}

Turkish and Hungarian are foreign tongues brought into the Indo-European area by recent intruders. Both these languages belong to the Altaic, Turanian, or Tataric family, spoken by nomadic tribes all over northern Asia, and including in Europe the Finnish and its congeners above mentioned. The Hungarian has especially strong affinities with the Finnish, while the nearest relatives to Turkish are to be found about Khiva and Bokhara, in the Tataric region which Russia is so rapidly subjugating.

We have now arrived at a tolerably correct idea of what is meant by the word Aryan. But one important point must not be overlooked. In its modern sense we have seen that the word is a linguistic term. It describes community of language. As we now use the word, Aryans are people who speak Aryan, or Indo-European languages. It is only in a secondary way that this word can be used as an ethnological term, describing community of race. We are so accustomed to consider language a mark of race that it is difficult to avoid using linguistic epithets in an ethnological sense, and a good deal of confused thinking sometimes results from this. We have above alluded to the Aryans as a dominan' race, which long since overran Europe and is now spreading over America; yet it is easy to see that we have no means of determining how far the various peoples who speak Aryan lan- 


\section{EXCURSIONS OF AN EVOLUTIONIST}

guages are of common descent. It is never safe to use language as a direct criterion of race, for speech and blood depend on different sets of circumstances, which do not always vary together. We of the English race have much Keltic blood in our veins, but very few Keltisms in our speech; while, on the other hand, with a vocabulary nearly half made up of Latin words, we have either no Roman blood in our veins, or so little as not to be worth mentioning. During the past twenty-five years Frenchmen have had a good deal to say about the "Latin race." There could hardly be a more flagrant instance of the perversion of a linguistic name to ethnological purposes. In reality, even in Cæsar's time, the dominant tribes of Latium had become viellnigh absorbed in the non-Latin, though kindred, I talic races which had succumbed to them. After Gaul had been conquered, it learned Roman manners, but without receiving any very large infusion of Roman blood. In point of race the French are Kelts, with a considerable substratum of Iberian and superstratum of Teutonic blood, - the former chiefly in the south, the latter chiefly in the north. Between Frenchmen, Spaniards, and northern Italians there is, indeed, a close ethnic affinity; but this is because they are all to a great extent Kelts, not because they have all learned to speak dialects of Latin.

Now if we pursue the matter a little farther, 
and inquire what we mean by saying that these three peoples are in great part Keltic, we shall find that a similar qualification is needed. $\mathrm{Ob}$ viously, we mean that they are Keltic in so far as they are descended from people who formerly spoke Keltic languages. Our knowledge of the prehistoric career of the Kelts is too small to admit of our meaning more than this. In just the same way, when we say that Spaniards and Englishmen and Russians are akin to each other as being Aryans, we can only mean that they are in great part descended from people who spoke Aryan languages.

There can be little doubt, however, that all races which have long wandered and fought have become composite to a degree past deciphering. And, however mixed may have been the blood of the Aryan-speaking invaders of Europe, it remains undeniable that the possession of a common language by such great multitudes of people implies a very long period of time, during which their careers must have been moulded by circumstances in common. It implies common habits of thought and a common civilization, such as it was. And this inference is fully confirmed by a comparative study of the myths and superstitions, as well as of the primitive legal ideas and social customs of the various parts of the Indo-European world. For this reason I think we are justified in speaking of the Aryan 


\section{EXCURSIONS OF AN EVOLUTIONIST}

race just as we speak, without error, of the English race, though we know that many race elements have combined their energies in the great work of English civilization. I do not say, either, that we may not fairly speak of a Latin race, provided we bear in mind the limitations of the phrase; the objection is not so much to the phrase as to the loose way in which it is customarily used and the absurd inferences which are often grounded on it.

The ethnologist, who deals with skulls and statures and complexions, may venture much farther, sometimes, than the linguist, - though perhaps the greater length of his excursions may not always compensate for their comparative insecurity. It is quite open to the ethnologist to hold that the successive Aryan swarms which colonized Europe were like each other in physiological characteristics, as well as in language and general culture. Differences of complexion, when well marked, are among the most conspicuous differences which distinguish individuals, groups, or races from one another; and they are, moreover, apt to be correlated with deepseated physiological differences of temperament. In all countries peopled by Europeans there are to be found two contrasted complexions, the blonde and brunette ; endlessly complicated and varied by intermarriage, but nevertheless in their extreme examples so strikingly different that a 


\section{OUR ARYAN FOREFATHERS}

stranger might well be excused for considering them as marks of difference in race. In populations that have long been stationary and isolated from foreign intrusion we do not find such differences of complexion. We do not find them in China or Japan, or among the Samoyeds, or Kafirs, or Pacific islanders, or among the Arabs. It appears to be only among the Indo-European nations that they occur side by side in the same community, as an every-day matter. Now we may account for this coexistence and intermingling of contrasted complexions by supposing that the various peoples of Europe have arisen from the intermixing in various proportions of a race that was entirely blonde with a race that was entirely brunette. We know that the Bask or Iberian race, which once seems to have possessed a great part of Europe, was, and still is, uniformly dark complexioned. We may, accordingly, suppose that the Aryan-speaking invaders were uniformly light. The effect of the earlier invasions of Kelts, Italians, and Greeks would be to crowd the dark-skinned Iberians into the three southern peninsulas, into western Gaul, and into the British Isles. The next step would be the conquest of all these regions, followed by extensive intermarriage and the general adoption of Aryan speech. In the remotest corner of all, cooped up between the Pyrenees and the Bay of Biscay, - here, if any- 


\section{EXCURSIONS OF AN EVOLUTIONIST}

where, a remnant of the aboriginal population might preserve its purity of race and its primitive speech. As a result of these proceedings, the Aryan-speaking peoples of Greece, Italy, Spain, Gaul, and Britain would show a mixture of light and dark complexions, and wherever the invaders had been much less numerous than the aborigines the brunettes would predominate. But now, where the later swarms of Teutons and Slavs came pouring in, the case would have been somewhat altered for them. Their conquerings and interminglings would take place not with a pure-blooded race of dark aborigines, but with the mixed race which had resulted from the foregoing events. One consequence would be an increased percentage of fair complexions in western countries overrun by Teutons, especially in England, northern France, and northern Italy. Another consequence would be the partial darkening of Teutons and Slavs by intermixture with Kelto-Iberian predecessors in southern Germany and Austria. Wherever, on the other hand, the newcomers were left pretty much to themselves, as in northern Germany, central Russia, and Scandinavia, we should find the auburn hair and blue eyes of the old Aryan still in the ascendant.

This very ingenious hypothesis, which is defended by such a cautious ethnologist as Pro- 


\section{OUR ARYAN FOREFATHERS}

fessor Huxley, ${ }^{1}$ accounts remarkably well for the actual distribution of light and dark complexions $^{2}$ throughout Europe. It agrees so well with the facts before us that we can hardly do better than adopt it as a provisional explanation, subject to such revision and amendment as may turn out to be necessary. But if we thus admit the existence of a primitive Aryan race that was physically homogeneous, it must be remembered that we admit it on very different grounds from those on which were based the demonstration of a primitive homogeneous Aryan language. The original community of language is a point on which we have reached absolute certainty; the community of race, in any other sense than that of long-continued community of language and culture, is largely a matter of speculation.

Concerning the people and the series of historic events of which Aryana Vaejo was the

1 On Some Fixed Points in British Ethnology, Critiques and Addresses, London, 1873, pp. 167-180.

2 We may go still farther in our discrimination between the aboriginal Iberians and the invading Aryans. It is probable that, along with black hair, black eyes, and brunette skins, the Iberians were distinguished by short stature, slight and compact frames, and long heads; while, on the other hand, along with their yellow hair, blue eyes, and blonde skins, the Aryans would seem to have been distinguished by tall stature, massive frames, and broad heads. See the preceding paper. 


\section{EXCURSIONS OF AN EVOLUTIONIST}

legendary starting-point, we have thus obtained much interesting and trustworthy information by the aid of the comparative method of inquiry. For be it observed that the results so far set down have been reached, for the most part, by a mere comparative survey of the various regions of the linguistic and ethnical field with which we have been called upon to deal. We have in this way obtained quite an accurate conception of what is meant when we speak of the Aryans. But as yet we have dealt only with the veriest rudiments of the subject. Nor have we as yet gone far toward illustrating the vast and rich resources of the comparative method. To be able to depict the prehistoric culture of the Aryan-speaking people, to interpret their mythical conceptions, and to unfold the other remarkable truths that lie latent in the variety of their speech, - this is indeed a fruitful achievement. But to show how this has been brought about requires a separate and more detailed form of exposition.

$\mathcal{F u l y}, 1876$. 


\section{IV}

\section{WHAT WE LEARN FROM OLD ARYAN WORDS}

$7 \mathrm{HE}$ discovery of the Aryan family of languages, as elucidated in the preced-

1 ing paper, was the first and most conspicuous consequence of the zeal for Sanskrit studies which ensued upon the English conquest of India. Surely, this in itself was no small thing. It was in every way stimulating and suggestive to have detected a specific bond of relationship, in speech and in culture, between such different peoples as the English and the Hindus, who had not previously been suspected of possessing anything in common save their common humanity. It had indeed been long ago maintained that languages the most diverse in superficial aspect were descended from a common source, but such views were based merely on a languid assent to an ill-understood tradition, and no one had the least conception of the proper method of tracing linguistic affinity. Down to the beginning of the present century the labours of etymologists had all the crudeness of astrological speculations, or of bar- 


\section{EXCURSIONS OF AN EVOLUTIONIST}

barian theories of the universe. And no wonder, since attention had been chiefly directed toward Hebrew, a language entirely unrelated to those of Europe, so that any attempt to explain the latter by a reference to the former could end only in mental confusion. It was a very striking discovery that was made when it was proved that though no likeness whatever exists between the European tongues and Hebrew, yet the closest similarity is manifest between these tongues and a much more remote Asiatic language. The completion of this discovery was no less striking when it was shown that while linguistic relationship can be clearly traced, according to fixed rules of inference, among all the various members of the Indo-European group, yet the moment we step outside of this group we can neither detect relationship nor establish rules of inference, but have before us a new set of facts, quite incongruous with the old ones. Such a contrast was just what was needed in order to indicate what the true signs of linguistic relationship are, and thus our whole mental horizon was shifted, as far as concerns the study of language. In the act of establishing the existence of our own great family of speech, scientific methods of comparison were gradually worked out, and the results of this have been far-reaching enough.

In the present paper I propose briefly to no98 


\section{OLD ARYAN WORDS}

tice two departments of study which have been actually created by the comparative investigation of Aryan languages. Under the first head I shall call attention to some characteristics of scientific etymology; under the second, we shall get a glimpse of the prehistoric culture of the Aryans.

First, as regards etymology, we need consider only a few facts which show how systematic and orderly inference has been substituted for what once was mere random guess-work. In comparing different languages, similarity and dissimilarity are still, as formerly, the principal tests of relationship; but in applying these tests we are strictly limited by rules which formerly were ignored. Once a vague resemblance between the vocabularies of two languages was considered sufficient ground for assigning them to the same class; now even a close and sustained likeness in vocabulary is not enough, unless it be accompanied by likeness in grammatical forms. Thus, the possession of innumerable Latin words, such as opinion, reflect, admire, umbrella, honour, colour, contemplate, criminal, etc., does not make English a language of the Italic class, nor does it even show any original kinship between English and Latin. Such words have simply been adopted from Latin, just as ennui and naiveté have been adopted from modern French, and such borrowing and lending as this can go on between any two languages. It is just as easy for us to use 


\section{EXCURSIONS OF AN EVOLUTIONIST}

Arabic words like alcohol and cipher as if Arabic were a kindred language. Nearly half the vocabulary of modern Persian has in this way come to be made up of Arabic words, yet there is no kinship whatever between Persian and Arabic. But while mere vocabulary does not determine the place of a language, the peculiar style of making sentences does determine it. Though more than half the words we use are Latin, English is not an Italic language, because we cannot make a single sentence out of Latin materials alone. English, on the other hand, is a Teutonic language, because we cannot make a single sentence without introducing some Teutonic shibboleth. Suppose we say, "Pantheism desecrates Deity :" nere we seem to have simply one Greek word followed by two Latin words; but the Teutonic shibboleth comes out in the terminal s of "desecrates," which is the peculiar shape in which English has retained the old Teutonic verb-ending $t h$, as it would appear in "desecrateth." Again, if I say, "I can go to Boston," my phraseology is purely Teutonic; but if, like Dr. Johnson, I have a weakness for big words, and say, "It is possible for this individual to traverse the vast area intervening between this locality and Boston," I have not yet escaped the boundary of Teutonic speech; for although I have introduced seven Latin words of secondary importance, yet the little words which enable me to knit the sen- 


\section{OLD ARYAN WORDS}

tence together are still Teutonic, as before. So when we say, "I have, thou havest or hast, he haveth, hath, or has," the Teutonic shibboleth comes out in this style of inflection. In short, it is easy enough for us to acquire new words, but we cannot abandon our habits of sentence-making without giving up our language altogether. Now the demonstrated community of the Aryan languages rests not merely on their possession of a common vocabulary, but on their retention, in various degrees, of grammatical forms originally common to all. We can hardly find a better instance than in the conjugation of the verb just alluded to: ${ }^{1}$ -

$$
\text { "TO HAVE." }
$$

Gothic, haba, habai-s, habai-th ; haba-m, habai-th, haba-nd.

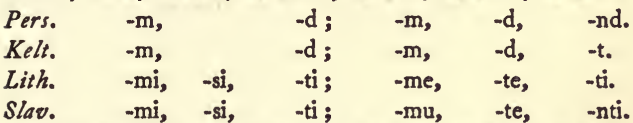
Lat. habeo, habe-s, habe-t; habe-mus, habe-tis, habe-nt. Gr. -mi, -si, -ti ; -mes, -te, -nti. Skr. -mi, -si, -ti; -masi, -tha, -nti.

Community of vocabulary is, however, a very important matter, when rightly considered. It is true that any language may borrow a large proportion of its words from an entirely alien source, as Persian has borrowed from Arabic. But in comparing the various forms of Aryan speech we

1 Whitney, Study of Language, p. 199. 


\section{EXCURSIONS OF AN EVOLUTIONIST}

have found a criterion which enables us to distinguish between the words that are alike in two languages because one has borrowed them from the other, and words that are alike because they are simply modified forms of the same aboriginal word. This supremely important point can be here treated but roughly; yet I hope that, with a few illustrations, it may be rendered intelligible.

One of the chief reasons for the divergence of a language, originally uniform, into two or more distinct dialects is to be found in those differences of pronunciation which arise, one hardly knows how, in different localities. The most curious feature of these differences is that they are often so extremely systematic. Every one has heard of the Englishman who inquired, "If a haitch and a ho and a har and a hess and a he don't spell 'orse, what in thunder does it spell, you know ?" The infallible accuracy with which the cockney omits his $h$ where it belongs, and supplies it where it does not belong, has always excited my wondering admiration. Were there any caprice in the usage, it would seem less marvellous. But so unerring is the instinct that when a friend of mine once purposely spelled his name out as U-t-t-o-n he was correctly announced by the waiter as Mr. HutTon! Is not this what our High German friends, with equal felicity, and in illustration of a similar point, 
would call a very eggsdraortinary zirgumsdance? Yet after all, so far from being extraordinary, such phenomena occur so regularly in a comparison of the Aryan languages that they have been reduced to a systematic form of expression in what is known as "Grimm's law." Take, for example, the word "father." This is the same in all the Aryan languages, save for the differences in pronunciation which make the Germans say vater, while in Latin, Greek, and Sanskrit we have pater. On the other hand, brother, in German bruder, appears in Latin and Sanskrit as frater or bhratar, in Greek as $\phi \rho a ́ \tau \eta \rho$, the member of a brotherhood or fraternity. That is, where we pronounce an $f$ the Greeks, Romans, and Hindus pronounced a $p$, but where we pronounce a $b$ they pronounce an $f$, or something like it. Similarly, where we say gard-en the Greek said $\chi$ ópros and the Latin hort-us; and our goose, which appears more fully in the German gans, is found in Greek as $\chi \hat{\eta} \nu$, in Sanskrit as hansa, in Bohemian as hus, the name of the celebrated martyr. But conversely, where we say heart the Greek said $\kappa a \rho \delta$ and the old Roman cord, and where the German says haupt the Roman said caput. That is, a Teutonic $g$ answers to a Greek, Latin, Sanskrit, or Slavonic $h$, but a Teutonic $h$ answers to a $k$ in the latter languages. Now this group of facts is not precisely analogous to the cockney's transposition of his aspirates, but it is 


\section{EXCURSIONS OF AN EVOLUTIONIST}

certainly very similar, and it is equally mysterious. Why this curious alteration of sounds should have occurred so systematically, and on so great a scale, no one has ever succeeded in explaining. It is none the less to the purpose, however, that it has occurred. Although an empirical rule, Grimm's law is nevertheless a well-established rule, and in the study of Aryan etymology it has to be taken into account at every step. It is easy to see what a revolution the establishment of this law has worked in our methods of comparing words. Formerly the etymologist looked, though in a vague, indiscriminate way, for mere resemblances; and this was natural enough. But now a too strict resemblance sometimes becomes a suspicious circumstance. The Greek word for "whole" is onos, and what could be more plausible than to suppose it identical with the English word? But here Grimm's law makes us suspicious. We ought not to expect a Greek to pronounce "whole" like an Englishman, any more than we ought to expect to hear a cockney say "horse." What the cockney says is "orse," and what the Greek would naturally say is not

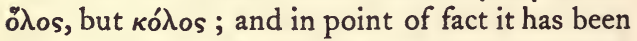
otherwise proved that our suspicion is here well grounded, - the resemblance between the English and Greek words is purely accidental. Mere resemblance is thus a very treacherous guide in etymology. In French we have louer, " to hire," 


\section{OLD ARYAN WORDS}

and louer, "to praise." Some philological dreamer tried to show that these words might be connected, because you praise your lodgings or horses when you wish to induce some one to hire them! In fact, the one word has been clipped down from Latin locare, "to hire," and the other from Latin laudare, "to praise." In striking contrast to this, let us observe how two English words, pen and feather, are closely connected in origin, in spite of their entire dissimilarity. There was an Old Aryan verb pat, " to

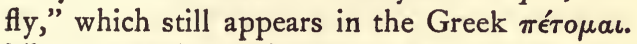
There were also such suffixes as tra and na, denoting the instrument with which an act is accomplished. Pat-tra thus meant "a wing," and a Hindu might perhaps thus understand it; but in Gothic we find fath-thra, and in English feather, just as Grimm's law has taught us to expect. Pat-na had the same meaning, and passed into old Latin as pes-na, which later Latin clipped down to penna, a wing or feather, and finally the quill-feather with which you write. In these days we have applied the word to little implements of gold or steel which have nothing to do with flying, unless the soaring of Pegasus be supposed to keep up the association of ideas.

This example of pen and feather is a very trite one, but I have cited it because it further illustrates a very important point, toward which 


\section{EXCURSIONS OF AN EVOLUTIONIST}

the argument has been for some time tending. Looking at these two words, with reference to the whole extant Aryan vocabulary, we find that their very forms disclose their past history. We see that the word feather, which has undergone the change of pronunciation indicated in Grimm's law, in common with Teutonic words in general, is a genuine Teutonic word, and appears in the English language to-day because it has always belonged to English speech. But the word pen, which has not undergone this change, shows thus on its very face that it has not grown up in company with Teutonic words, but has been adopted at a recent date from another branch of the Aryan family. The changes formulated in Grimm's law took place in early times, long before people had begun to think critically about their pronunciation or their diction. When we adopt Latin words in modern times, we do not refashion them in accordance with the twisted pronunciation of our barbaric ancestors, but we take them as they are. From pater we take paternal, without trying to make it sound like its equivalent, fatherly. Thus we arrive at a safe criterion for distinguishing between words which have been passed about from one Aryan language to another, in the course of recent intercommunication of culture, and words which have descended, with divers modifications, from a common original. Words of the 106 


\section{OLD ARYAN WORDS}

latter sort, where they exist in different classes of Aryan speech, have obviously been handed down from primeval times; they must have formed part of the vocabulary employed in Aryana Vaëjo, and the most convincing proof of their genuineness is to be found in the peculiar nature of the wear and tear they have undergone. To recur to an example previously cited, the existence of such English words as colour, opinion, admire, etc., not only fails to prove kinship between English and Latin, but it does not even prove that English is an Aryan language, since these words are manifest importations, and the case of Persian and Arabic shows that nothing is easier than for one language to adopt half its current words from another that has no relationship with it. But on the other hand, when we compare such words as corn with Lat. granum; horn with Lat. cornu; who and what with Lat. quis and quid, Skr. kas and kad; queen with Gr. $\gamma v \nu \eta$; beech with Lat. fagus; doom with Gr. $\theta$ é $\mu \iota s$; tear with Skr. dar; bear with Skr. bhar, Gr. and Lat. fero; tooth (Goth. tunthus) with Zend and Skr. dant, Lat. dens, when we find a thousand such cases of systematic divergence, we get clear proof of the original identity of the English vocabulary with the others brought into the comparison. For the divergences in themselves are incompatible with any theory of modern borrowing and lend- 


\section{EXCURSIONS OF AN EVOLUTIONIST}

ing, while the extreme regularity of their recurrence is explicable only as the result of common processes operating on common materials.

The symmetry of consonant-changes throughout the Aryan languages is at first sight a wonderful phenomenon, and the tracing of correlated words in accordance with such laws as Grimm's never ceases to be a fascinating study. The laws of vowel-change - whereby, for example, the Skr. matar corresponds to Lat. mater, Gr. $\mu \eta^{\prime} \eta \rho$, Gaelic mathair, Germ. mutter, and Eng. mother - are hardly less interesting. But to do justice to such a subject as etymology would require much more time than we have at our disposal. In the present paper I have not attempted to make anything like a full statement even of Grimm's law, but have given only such scanty illustrations as may serve to render the outline of the argument intelligible while I go on to point out one of the largest of the results that have come from this minute study of consonants and vowels. From this minute study the laws of the permutation of words have been wrought into such a complete and harmonious system that it has become possible to reconstruct large portions of the common Aryan mother tongue by comparing together the curiously modified forms of its modern descendants. The problem is quite similar to what it would be if classical Latin were I08 


\section{OLD ARYAN WORDS}

extinct, and we were required to reproduce as much as possible of it from an elaborate comparison of the vocabularies and grammatical forms of French, Spanish, Italian, and their allied modern dialects. Such a task would no doubt be delicate and difficult; but there is also no doubt that a great deal of good Latin could be reconstructed in this way. The restoration of the Aryan mother tongue seems at first sight a still more formidable task; but it is a task for which we have also more abundant materials in the wider variation among Aryan words as compared with Romanic words. Thus by a comparison of French mois with Span. mes and Ital. mese, knowing besides the general habits of the Romanic languages, we might probably infer the Lat. mensis as the common original of the three; but on looking over the whole Aryan field, and comparing Lat. mensis with English month, Gr. $\mu \eta^{\prime}$, Lith. menesis, O. H. G. manot, and Skr. masa, we arrive with even stronger probability at the Old Aryan mansa as the only form which could have given rise to all these.

During the last twenty years it may almost be said that the great work of Aryan philology has been the reconstruction of the Old Aryan mother tongue. At least the comparative researches that have been made have owed their chief interest to their bearing on this problem. In philology, as in zoölogy and botany, ques- 


\section{EXCURSIONS OF AN EVOLUTIONIST}

tions of classification have become irretrievably implicated with questions of genealogical kinship. Whether we are considering consonants and vowels, or the case-endings of nouns, or the syntax of moods and tenses, it is impossible to describe accurately the relations of the several Aryan languages to one another without involving a perpetual reference to the common original from which these languages sprang. The first noteworthy attempts at reconstructing the mother tongue were made by the great philologist August Schleicher, who by way of giving a popular illustration of his abstruse results once wrote a little fable in Old Aryan. This jeu d'esprit of Schleicher's has been so often alluded to that I am tempted to quote it here, with an English translation. To any classical scholar, who has also a slight acquaintance with Sanskrit and Gothic, the sense must shine so clearly through the Old Aryan words that the translation will hardly be needed.

\section{Avis akvasas ka.}

Avis, yasmin varna na a ast, dadarka akvams, tam, vagham garum vaghantam, tam, bharam magham, tam, manum aku bharantam. Avis akvabhyams a vavakat: kard aghnutai mai vidanti manum akvams agantam.

Akvasas a vavakant: krudhi avai, kard aghnutai vividvant-svas: manus patis varnam 


\section{OLD ARYAN WORDS}

avisams karnauti svabhyam gharmam vastram avibhyams ka varna na asti.

Tat kukruvants avis agram a bhugat. ${ }^{1}$

The Sheep and the Horses.

A sheep, whose wool had been shorn, looked upon the horses as they drew a heavy wagon, bore a great load, or swiftly carried a man. The sheep said to the horses, "It grieves my heart to see Man driving horses."

The horses said, "Listen, sheep; it grieves our hearts to think how the despot Man makes his warm garment of sheep's wool, while the sheep goes woolless."

On hearing this, the sheep quit the field.

In the simple diction of this little apologue, there can be no doubt that we have a very close approach to the words that our Aryan forefathers would have understood in the days before they had as yet invaded Europe and mixed with the swart Iberian, whom - physically though not linguistically - we also reckon as our ancestor. But with respect to such attempts at reproducing the Aryan mother tongue in its concrete reality, there is one thing which we must always bear in mind. Granting that a word A and a word B both existed in Old

1 Kuhn and Schleicher, Beiträge zur vergleichenden Sprachforschung, v. 207. 


\section{EXCURSIONS OF AN EVOLUTIONIST}

Aryan, in the time of the Spracheinheit, we do not know but A may have become obsolete before $B$ came into general use. So that, if we were to try to write out a long story after Schleicher's example, though each individual word might be correctly reproduced, we should run great risk of writing an Old Aryan style as anomalous as would be the style of a writer of hypothetical English who should mix up in one and the same sentence the diction of Chaucer, of Dryden, and of Longfellow. It is difficult, at present, to see how chronological considerations can be applied to the vocabulary of Old Aryan, in the absence of that kind of historic evidence which written records or inscriptions alone can furnish. In the last resort, comparative philology is an historical science. Though it can, within a limited range, perform wonderful feats of inference, quite comparable with such as are achieved by the physical sciences, yet after all, the tether by which it may stray from its historic base is not a long one. The science of language must always be studied mainly by the help of documentary evidence.

Yet while this chronological difficulty would seem to render hopeless the accurate restitution of the Aryan mother tongue as a whole, we can none the less restore or reconstruct individual Old Aryan words with a fair approach to accuracy. And a very extensive Old Aryan 


\section{OLD ARYAN WORDS}

vocabulary has already been thus obtained, as we may see in the three goodly octavos of Fick's great dictionary, in which a primitive Aryan warrior - if we could first resuscitate him and then teach him to read - would no doubt find himself more or less at home. ${ }^{1}$

In no respect do these philological inquiries appear more interesting than in the light which they throw upon the prehistoric civilization of our Aryan-speaking forefathers. No historic record, not even a vague tradition, is preserved of the time when the blue-eyed ancestors of Kelt, Greek, Roman, and Teuton dwelt in a single community with the ancestors of Persian and Hindu. We have no clue even to the date of this epoch of common Aryanism, though we may very fairly allow for it perhaps three or four thousand years before the Christian era. Even the oldest Aryan legends, as those of the Vendidad, preserve only a dim reference to a time when the Indo-Persian branch of the family had not yet become divided. Yet concerning the degree of culture reached in those remote times, so far antedating all conscious historic tradition, the unconscious record of language has given us some trustworthy information. From the seemingly dry study of consonants and vowels an easy process of inference

1 Fick, Vergleichendes Wörterbuch der Indogermanischen Sprachen. 3 d edition, Goettingen, 1874-76. 3 vols. 8vo. 


\section{EXCURSIONS OF AN EVOLUTIONIST}

opens up to us, as with a magician's wand, a fascinating picture of the life and pursuits and habits of thought of the people from whose long-perished form of speech our vowels and consonants are derived.

Wonderful as this may seem, what is simpler, when we have once ascertained that a certain word belonged to the Old Aryan language, than the inference that the word was used to describe some object or express some thought? And where the meaning of the word has remained uniform throughout all the vicissitudes of pronunciation and inflection to which it has been subjected, what better guarantee do we need that the word was used with the same meaning in the mother tongue? It requires no extraordinary insight, when one has mastered the rules of comparative grammar, to see that the primitive Aryan called his nearest relatives by the names patar, matar, bhratar, svasar, sunu, and dhugatar; or that when he learned to count up to ten he said something like aina, dva, tri, katvar, pankan, ksvaks, saptan, aktan, navan, dakan.

Proceeding in this way, we find abundant evidence that the early Aryans had outgrown the nomad stage of civilization and acquired settled habitations, not merely in villages, but even in fortified towns. The Lat. domus reappears, with hardly any change, in Gr. Só $\mu$ os, Skr. dama, Armen. dohm, Irish daimh, and Russ. 


\section{OLD ARYAN WORDS}

domu, always with the meaning of " house." In the Teutonic class we do not find this word in precisely the same sense; but we have the Germ. zimmer, " a room," connected with Goth. timrjan, " to build," and Eng. timber, or "building material ;" and these words, compared with Gr. $\delta \epsilon e \epsilon \iota \nu$, carry us back to Old Aryan dam, " to build," so that the domus of our forefathers was not a mere hole in the rocks, but a dwelling-place put together by the art of the carpenter. In Greek the more common word for house is oikos, originally Foikos, " a place that one goes into." This word runs through all the Aryan languages, but the original sense of "entering" is forgotten, and it only means " a place where one lives," - sometimes a house, but more generally a village. Thus we have Skr. veça, Zend viç, Russ. vesi and Polish wies, Lat. vicus (whence the diminutive vicula, villa, village), Irish fich, Kymric gwic, Goth. weihs, Eng. wick. The Old Norse language shows a curious deviation from this general agreement in meaning; for whereas the word generally describes an abode on the land, to the sea-roving Norseman a wick was a creek or sheltered bay serving as a station for ships, and hence their famous name of Vikings or "men of the fjord." So, while the ending wick or wich is very common in old English names of inland towns, it occurs frequently also on the British 


\section{EXCURSIONS OF AN EVOLUTIONIST}

coasts in the Norse sense, as in Sandwich and Berwick, favourite stations for pirates. But with this characteristic divergence, the generally uniform significance of the word, in languages so widely scattered, points clearly to the existence of village communities among the prehistoric Aryans. The various forms of the English word town are equally instructive, though not quite so numerous. The Old English form tun has its counterpart in Old German zun, "an inclosed or fortified place," with which the modern German zaun, "a hedge," is connected. Now, in accordance with Grimm's law, we find Armenian dun, "a house," Kymric din, "a fortress," Irish dun, a "fortress " or "camp " or "walled town." This Keltic form appears in many geographical names, such as Thun, in Switzerland; Lug-dun-um on the Rhone, now Lyons; Lug-dun-um in Holland, now Leyden; Dun-keld, the "fort of the Kelts;" Dum-barton, the "fort of the Britons;" Dundee, London, Clarendon, etc. In the remote Himalayas the same word reoccurs in the names of hill fortresses, such as Kjarda Dhun, Dehra Dhun, etc. ; and again it is a fair inference that where a word turns up in so many parts of the Aryan domain with the very same determinations of meaning, it must have belonged to the primitive vocabulary of the race. So that our forefathers would appear to have been acquainted not only with I 6 
houses and villages, but also with some kind of walled towns.

The name of the rampart with which such fortified inclosures were surrounded was also contained in the Old Aryan vocabulary. From the old root val or var, to " protect " or " surround," we have Skr. varana, Old Germ. wari, Pol. warownia, Lat. vallum, Lith. wolas, Irish fal, Kymric gwal, Eng. wall. The partition wall of a house, on the other hand, is more properly described by a root which in Sanskrit seems to be applied to wicker-work, but which in the European tongues appears, with hardly any variation either in sound or sense, as Lat. murus, Lith. muras, Old Germ. mura, modern Germ. mauer, Irish, Kymric, Old Eng., and Pol. mur. The name for "roof" is similarly ubiquitous : in Skr. we have sthag, "to cover," in Lith. stogas, "a roof," in Gr. oré yos, a "roof"

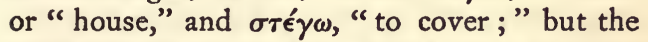
word appears about as often in Greek as $\tau$ ćyos, with the initial letter dropped; and so in Irish we find teg, "a house," in Lat. tego and tectum, in Old Eng. thecan, in Eng. deck and thatch. In door there has been even less variation than this : Skr. has dvar, and also dur in the Vedas; Zend dvara, Pers. dar, Gr. Av́pa, O. H. G. tura, Goth. daur, Old Eng. duru, Irish and Welsh dor; the Lithuanian has lost the singular, but retains the plural durrys for folding-doors. The 


\section{EXCURSIONS OF AN EVOLUTIONIST}

word meant originally " that which obstructs or keeps out." Another old name for the door, which appears in Skr. as arara, has been preserved in Europe only in the Irish orair, a "porch" or "vestibule," and Welsh oriel. This latter is one of the very few Keltic words to be found in English, where it has become the name of a kind of bay-window.

Among the Aryan words for "window" there is no such identity, though there is a most curious similarity in the metaphors by which they have been constructed. In Sanskrit the window is grhaksha, or " the eye of the house," and a big round window is called gavaksha, a compound of gau, "cow," and aksha, "eye," which is about equivalent to our expression "bull's-eye." The Slavonic languages have okno, from oko, "an eye," while Gothic has augadauro and O. H. G. augatora, or "eye-door." The meaning of our English word is not so immediately apparent, but in one of our nearest relatives, the Danish, it occurs as vindue, and in Old Norse this was vindauga, that is, "an eye or hole for the wind to blow through." These coincidences are interesting as showing how easily and naturally the same association of ideas may occur to different people, for these words have been independently formed. Whether we are entitled to infer from this that the Aryan mother tongue had no word for window, and 


\section{OLD ARYAN WORDS}

that therefore the people who spoke it lighted and aired their houses only through the doorway, it is not easy to decide. It is very unsafe to rest a conclusion upon negative evidence. The old Aryans certainly might have had a name for window which among various tribes came to be supplanted by various other expressions. Accordingly we can only say that, while we are perfectly sure that they had doors, it is quite uncertain, so far as philology goes, whether they had windows or not. And in general, while the occurrence of the same indigenous name for any object, throughout the different classes of Indo-European speech, is sufficient proof that the primitive Aryans knew and named the object, on the other hand, the non-existence of such a common name raises only a negative presumption, which we have seldom any further means for testing.

The ancient Aryan gained a livelihood chiefly from rearing cattle and tilling the ground. The names of our principal domestic animals are found in all parts of the Indo-European territory. The various Teutonic terms, cow, $k u$, chuo, reappear with the proper change of guttural in Lettish gôws, Pers. gâw, Armen. gov, Zend gao and gava, Skr.gaus, gava, and gu. A peculiar twist, by which a labial was pronounced, instead of an original guttural, may be observed quite frequently in the Græco-Roman and Keltic lan- 


\section{EXCURSIONS OF AN EVOLUTIONIST}

guages, and here we have Gr. ßov̂s, Lat. bos, Irish bo, and Welsh bu. The meaning of the word has been variously explained, but, as we have beside it the Skr. gu, Gr. yoá $\omega$ and $\beta o a ́ \omega$, Lat. boao, to "bellow," it is most likely an imitative sound, like our moo and mooley. In the dialect of the Vedas a bull is called vâksha, in later Skr. and Zend uksha; in Gothic this appears as auhsa, and in Old Eng. as oxa, whence our ox. Sthira, again, is a Skr. name for bull, meaning the "powerful" animal. In Zend çtaora means a strong beast of burden; in English we have kept the full word steer, but the initial $s$ has generally been dropped, so that we have Dan. tyr, Gr. and Lat. taurus, Russ. turu, Irish tor. The word bull itself is descriptive of the strength of the animal, and appears in Skr. balin, Irish bulan, Lith. bullus, and in many other languages. There are a great many other Aryan names for these animals, but without spending time on them we may note that several of the words just cited have been borrowed by non-Aryan languages, such as those of the Finno-Tataric class, and even the Japanese and Chinese; from which it would seem probable either that the primitive Aryans were the first to domesticate cattle, or at least that they were very preëminent as a pastoral race, and furnished to their neighbours great numbers of these most useful animals. The prominence of the cow 


\section{OLD ARYAN WORDS}

in early Aryan thought is shown both by the multitude of synonyms for the creature, and by the frequency of similes, metaphors, and myths in the Vedic hymns in which the cow plays a part. In those days, moreover, which were before the days of "soft" or " hard " money wealth was reckoned in cows, and cows were the circulating medium, with sheep and pigs for small change. Every one knows that Lat. pecunia is derived from pecus, "a herd;" the same is true of peculium, "a man's private property," from which we have obtained peculiarity, or "that which especially pertains to an individual." Pecus, Lith. pekus, Skr. and Zend paçu, "the animal that is tied or penned up," reappears with the regular change in Goth. faihu, Old Eng. feoh, modern Germ. Vieh; in modern English the word has become fee, a " pecuniary reward." In Irish we have bosluaiged, "riches," from bosluag, " a herd of cows." When you go to a tavern to dine you pay your shot or scot before leaving ; or you sometimes, perhaps, get into a very ticklish situation, and still escape scot-free. In Old Eng. sceat was "money," and the Old Norse skattr and Goth. skatts had the same meaning; but the Irish scath means "a herd," and Old Bulgarian skotu was one of the many Aryan words for cow. Another of these words in Skr. is rupa, whence are derived rupya, " money," and the modern rupee of Bengal. 


\section{EXCURSIONS OF AN EVOLUTIONIST}

More than a hundred different names for the horse have been counted in Sanskrit, but most of these are comparatively modern in origin. The only one we need notice is açva, from an Old Aryan akva, meaning "the swift." In Lith. the same word aszwa is the name of the mare only, but the Lat. equus preserves the old

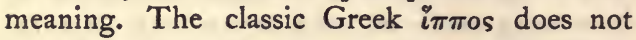
sound so much like equus as one might expect, but we find the requisite transitions in the Aiolic $\hat{\imath} \kappa \kappa o s$ and Old Aiolic $\hat{\imath} \kappa$ Fos. In Irish nothing is left but the first syllable, ech. In Gothic the word reappears quite regularly as aihva, and in Old Eng. this is clipped down into eoh. Modern English, however, and the other Teutonic languages have lost this word and replaced it by another, which goes back to the times of Teutonic unity, but does not seem to have been known to the primitive Aryans. The Old High Germans and the Norsemen pronounced this word hross, but the oldest Teutonic form was probably horsa, from a root hor, identical with Lat. currere, "to run." Horse is accordingly connected by bonds of etymological kinship with its descriptive synonym courser. Modern High German, in turn, though it has not lost the word ross, has adopted a new name, pferd, which is in more frequent use, and the history of which is extremely curious. 


\section{OLD ARYAN WORDS}

One of the few Keltic words which the Roman conquerors adopted from their Gaulish subjects was the word rheda, used to describe a light fourwheeled carriage. Such carriages were used for posting, and the light, swift animal which drew them received a special name, made by compounding the root of veho, to "draw" or "carry," with the name of this kind of carriage. Thus arose the word veredus, "the drawer of the rheda," the post-horse, or courier's horse ; and so veredarius was a post-classic Latin word for "courier;" but the name veredus was not long in becoming generalized, for in Martial we find it used for a light, fleet hunting horse. At the same time there came into general use the curiously hybrid word paraveredus, made by prefixing the Greek preposition $\pi a \rho a$, meaning "beyond," to veredus, to denote an extra posthorse for extraordinary occasions. This mongrel word paraveredus, thus oddly made up out of Greek, Latin, and Keltic elements, seems to have been a favourite name for the horse in the Middle Ages. In Ducange's great dictionary of mediæval Latin we find parvaredus, parafredus, and palafredus, along with many other forms. From palafredus came the French palefroi and the English palfrey; while the simple contraction and abbreviation of the older paraveredus resulted in the form $p$ ferd adopted by the modern German. 


\section{EXCURSIONS OF AN EVOLUTIONIST}

As the Teutonic languages have thus adopted new words to designate the horse, so the modern Romanic languages have generally forgotten equus and substituted for it the name which appears in French as cheval and in Italian as caballo, and from which we have obtained such words as cavalry, chevalier, and chivalry. Ancient Greek and Latin both had this word caballus, which, as kobyla, is the common name for a horse in the Slavonic languages, and appears also in Irish as capall and in Welsh as ceffyl. We do not find any such name in Sanskrit, but in the Kawi of the island of Java, which is a non-Aryan Malay language, as full of Sanskrit words as English is of Latin words, we find the horse called capala, and side by side with this we have in Sanskrit the adjective çapala, "swift." The Sanskrit quite generally corrupted Old Aryan $k$-sounds in this way, as we corrupt Latin sounds in English when we say serebrum and Sisero instead of kerebrum and Kikero; and I have no doubt that in this word for "swift" we have the explanation of caballus. Curiously enough, the modern Greek has also dropped the classical name for the fleet-footed

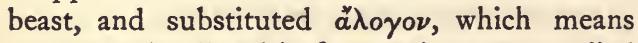
" unreasoning," and in former times was applied to brutes in general. It is quite remarkable that there should have been such vicissitudes in the career of the words which describe so 


\section{OLD ARYAN WORDS}

familiar an animal, and we need no better illustration to convince us of the danger, above pointed out, of relying too confidently upon negative evidence in such inquiries as we are here making. Looking at the contemporary names only, we find the English and French saying horse and cheval, "the swift runner," while High German and Greek say pferd, "the extra drawer of a post-carriage," and a $\lambda o \gamma o \nu$, "the brute," - names quite distinct both in sound and in meaning. If all the other forms had been lost and replaced by new words, - as might easily be the case where there are so many synonyms for the same object, - we might perhaps have inferred that there was no common Aryan name for the horse, and that hence the animal was not known until after the separation of Aryan tribes had begun; but this would have been very plainly a mistake.

Besides the horse and cow, the primitive Aryans had domesticated sheep, goats, and pigs, as well as dogs. With regard to the cat, the case is less clear. That wild species of the cat family were known seems probable, and the word puss has some claim to an Old Aryan pedigree, for we find pushak in modern Persian, puizé in Lithuanian, pusag and puss in Irish, whence we have adopted the word; but whether the primitive form of these names was applied to a wild or to a domesticated cat is uncertain. With this 


\section{EXCURSIONS OF AN EVOLUTIONIST}

exception, the Indo-European names are all different. In Latin we have felis, in Greek ai $\lambda$ ovpos; but we know otherwise that the Greeks and Romans had no domestic cats, but kept a kind of weasel to destroy their rats and mice. In our own and most other modern European languages the principal name of the animal is borrowed from Latin; but the Latin catus is itself an imported word from a non-Aryan source. It is the Syriac kato, Arabic kitt, indicating that the cat was introduced into Europe from the Levant, at a comparatively recent period.

But whether the Old Aryans had domestic cats or not, they certainly needed them, for the word mouse occurs, with hardly any variation, in nearly all the Indo-European languages. In Latin, Greek, Old Norse, Old German, and Old English it is mus; in Russian we have myshi, in Bohemian mysh, in Persian mush, in Sanskrit musha, the "pilfering creature," the " little thief."

Flies are also to be numbered among the household pests of Aryana Vaëjo; the old name was makshi, the "buzzing creature," and is preserved in Zend and the modern Indian languages. In Europe we have Lith. musse, Bohem. musska, Lat. musca, O. H. G. muccha, Swed. and Old Eng. mygge, Eng. midge, of which the dim:nutive midget, or " little fly," has been applied 


\section{OLD ARYAN WORDS}

as a caressing epithet to children. The meaning of the more common Teutonic name " $\mathrm{fly}$ " is too obvious to require mention.

The ordinary Aryan name for "bee" - Skr. bha, O. H. G. pia, Old Eng. beo, Eng. beerefers to the bright colour of the insect, but the Lat. apis is the "thrifty creature" and the Greek $\mu \epsilon ́ \lambda \iota \sigma \sigma \alpha$ is the "maker of honey." The Old Aryans not only kept bees for their honey, but out of the honey they made an intoxicating drink called madhu, from which we have the Zend madhu and Greek $\mu \epsilon ́ \theta v$, "wine," Russ. mëdü, Irish meadh, Old Eng. medu, Eng. mead. Wine and must are Old Aryan words, and the same is probably true of ale; but in this latter instance we cannot safely infer that what we call ale was brewed, for the meaning of the word has varied considerably. Lith. alus, Old Norse öl, Old Eng. eala, mean "beer," but the Skr. ali means a spirituous liquor, and the Irish ol is applied to any kind of drink. As for the word beer itself, it is doubtful if it can be traced outside of the Teutonic languages; for although it occurs in Irish, Welsh, and modern Persian, it does not conform to Grimm's law, and has thus most likely been borrowed from English or some other Teutonic source.

Whether our Aryan forefathers brewed ale or not, they certainly cultivated barley and probably wheat, and ground them into meal in mills. 
They were familiar with the plow, the yoke, and the spade. Their harvests were reaped with a sickle, and the grain was duly threshed and winnowed, and carried to mill in wagons fitted with wheels and axle-trees. The blacksmith's work with hammer and anvil, forge and bellows, was also carried on. Sewing and spinning were feminine occupations, and garments were woven out of sheep's wool. The art of tanning was also practised, and leather shoes were worn. The entire career of the Aryans has been that of a warlike people. In the primitive times of which we are treating, their principal weapons were the lance, the bow and arrow, the sword and dagger and mace, with helmet and buckler for defence.

That the early Aryans were acquainted with the sea seems unquestionable, for the name occurs, with very little change in sound and hardly any in meaning, in nearly all the Indo-European languages. The Lat. mare, whence our adjective marine, appears in Skr. mira, Russ. moru, Lith. mares, Irish muir, Welsh mor, Goth. marei, O. H. G. mari, Old Norse mar, Old Eng. mere. In English meer is an archaic word, still used in poetry in the sense of "lake," and it appears in many well-known names of English lakes, as Grasmere and Windermere. The original sense of the word has something poetic in it, for it means the barren, desolate waste, just as we find it commonly described in Homer. The 


\section{OLD ARYAN WORDS}

Teutonic languages, however, have generally adopted another name. In Skr. sava means simply "water," but the more specific sense appears in Goth. saivs, O. H. G. seo, Old Eng. sew, Eng. sea. It is noticeable that while modern English applies this name to great bodies of water, and keeps meer only in the sense of lake, in modern German the case is just the reverse, in German meer is the sea, but see is a lake. The only other conspicuous deviation from the general Aryan usage is a very characteristic one. The Greeks, who were the most maritime of all peoples that have existed, save the English, had three names for the sea, of which the later $\theta a ́ \lambda \alpha \sigma \sigma a$ and $\pi \dot{\epsilon} \lambda a \gamma o s$ referred to the boisterous, white-crested waves, but the earlier $\pi$ óvтos meant a "pathway for travel." What large bodies of water the primitive Aryans could have known is not fully ascertained, but they were perhaps the Caspian and the Sea of Aral. On these inland seas, or along the great rivers which flowed through their country, the Aryans would seem to have plied in boats rowed with oars; but whether they had advanced farther than this is uncertain. At all events, there is a singular lack of agreement among all the common words indicative of a higher acquaintance with the art of navigation.

With these illustrations we must bring our exposition too abruptly to a close. By the course 


\section{EXCURSIONS OF AN EVOLUTIONIST}

of inquiry we have followed, something might be brought out concerning the political organization of the primitive Aryans, which appears to have been extremely simple. "The people," says Professor Whitney, "was doubtless a congeries of petty tribes, under chiefs and leaders rather than kings, and with institutions of a patriarchal cast, among which the reduction to servitude of prisoners taken in war appears not to have been wanting." This inquiry, however, would take us far beyond our limits, and might be more advantageously conducted in another connection, where we might avail ourselves of the harmonious results which Sir Henry Maine, Mr. Freeman, and others have elicited from a comparative survey of Indo-European politics and jurisprudence. But this most interesting and profitable study must be postponed to another occasion. In the present paper, confining myself chiefly to the material circumstances of the primitive Aryans, I have endeavoured only to give some idea of the method by which sound conclusions are reached, through the study of words, concerning the civilization of an age of which the historic tradition has been utterly lost. More than this could not well be attempted in so brief an exposition. The examples have been scanty, and from the nature of the subject they may perhaps have seemed rather dry. It is not in a moment that one can become fully possessed 


\section{OLD ARYAN WORDS}

with the rare fascination which surrounds the study of the historic lessons conveyed in words. Yet possibly to some reader it may have come as a novel and striking thought that out of mere grammars and dictionaries a trustworthy picture of the long-forgotten past may be reconstructed. Inadequate as our illustrations have been, none can fail to perceive the historic interest and value of the information which has been gained in this way. Inquiries of this sort need, no doubt, much caution and sagacity to be conducted successfully; but when properly sifted there is no more unimpeachable testimony to the past than that which the aspect of words gives us. For the changes of vowel and consonant proceed according to general laws which observations may detect, but with which no individual will is able to tamper. And thus it is that in the winged word which seems to perish in its flight through the air we have nevertheless the most abiding record, though unwittingly preserved, of the knowledge and achievements of mankind.

August, 1876 . 


\section{V}

\section{WAS THERE A PRIMEVAL MOTHER TONGUE?}

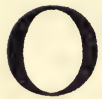

F all the great changes in thought which the present century has witnessed, perhaps none is more striking than that which has occurred in our methods of studying the beginnings of human culture. The discoveries of Grimm and Bopp in comparative philology, the decipherment of mysterious inscriptions in Egypt and Assyria, the study of legal archæology illustrated by Sir Henry Maine, the doctrine of survivals so ably expounded by Mr. Tylor, and especially the geologic proof of the enormous antiquity of the human race, together with the wide-reaching and powerful speculations of Mr. Darwin, have all contributed to bring about this change. So completely has our point of view been shifted by these various theories and discoveries that many speculations which at the beginning of the present century possessed an absorbing interest have now come to seem frivolous or irrelevant; and nothing can better illustrate the extent of the change than the fate of some of these speculations. It 


\section{A PRIMEVAL MOTHER TONGUE}

is not many years since ethnologists were racking their brains to show how the North American Indians might have come over from Asia ; and there was felt to be a sort of speculative necessity for discovering points of resemblance between American languages, myths, and social observances and those of the Oriental world. Now the Aborigines of this continent were made out to be Kamtchatkans, and now Chinamen, and again they were shown, with quaint erudition, to be remnants of the ten tribes of Israel. Perhaps none of these theories have been exactly disproved, but they have all been superseded, and have lost their interest. We now know that in the earliest post-Pliocene times, if not in the Pliocene age itself, at least four hundred thousand years ago, the American continent was inhabited by human beings. The primeval Californian skull, moreover, resembles the modern American Indian type, and is not to be confounded with Old World skulls. It is probable, therefore, that far back in postPliocene times, before the great glacial period, the ancestors of the American Indians had already become distinguished from the races of Asia. Now both before and since that time the eastern and western continents have been repeatedly joined together at their northern extremities. In view of such facts, whatever opinion we may ultimately adopt, we feel that all 
theories of the recent colonization of America by Kamtchatkans, or Chinamen, or the ten tribes of Israel, are superseded and laid on the shelf. That recent migrations may have occurred is quite another affair. Theories like those of Brasseur de Bourbourg are still to be treated on their own merits, independently of general considerations. But one now perceives, in reading them, that they were dictated by a kind of speculative necessity which we no longer feel, because our whole point of view has been shifted.

In similar wise have fared the innumerable plans which formerly occupied the attention of scholars for colonizing the whole world from the. highlands of Armenia. The ethnological information contained in the Book of Genesis is of great interest and value, but so far from relating to the whole human race, it totally ignores the larger part of the world, and is concerned only with the peoples of which an inhabitant of Syria might be expected to know something. Long before any possible date for the diffusion from Armenia there described, we know that populous and stationary communities flourished on the banks of the Nile and the Euphrates; while savage or barbarous tribes, using stone hatchets and flint-headed arrows, wandered through the primeval forests of Europe and America. Armenia retains its interest, to some extent, as a possible starting-point, but only in connection 


\section{A PRIMEVAL MOTHER TONGUE}

with the Semitic race and its neighbours, - so thoroughly have our notions been remodelled.

Old-fashioned speculations concerning the primitive unity of human speech have similarly fallen into discredit. Previous to the detection of the kinship between the various forms of Aryan speech, no end of books were written to prove that all known languages were in some way descended from Hebrew; not that there was any warrant for such an opinion, either in Scripture or in the general probabilities of the case, but that the preeminence of Hebrew as the language of Jehovah's chosen people and the vehicle of divine revelation created a speculative need for proving it to be the original uncorrupted dialect of mankind. Since the establishment of the Aryan family of languages, it has still been felt necessary to prove that all existing varieties of speech have had a common origin, and as a step toward this end great learning and ingenuity have been expended in the attempt to detect some primordial similarity between the Semitic languages and languages of Aryan descent.

It is not too much to say that all this learning and ingenuity have been utterly wasted. Apart from a few casual coincidences, as in the $\mathrm{He}$ brew and Sanskrit words for six, there is not a trace of similarity between the Semitic and the Aryan vocabularies; while as regards both in- 


\section{EXCURSIONS OF AN EVOLUTIONIST}

flection and syntax, the entire structure of these two families of speech is so radically unlike, that only the most desperate feeling of speculative necessity could ever have induced any one to seek a common original for the two. But after getting irretrievably worsted in the encounter with facts, this speculative craving is now outgrown and laid aside with the others. The antiquity of the human race again comes in to alter entirely our standpoint. Considering how multifariously language varies from age to age, and considering that mankind has doubtless possessed the power of articulate speech for some thousands of centuries, it no longer seems worth while to seek immediate conclusions about primitive speech from linguistic records which do not carry us back more than four or five thousand years.

From the vantage-ground which we now occupy, it is not difficult to see that the hypothesis of a single primeval language, from which all existing languages have descended, involves an absurd assumption. Those who maintain such an hypothesis, in so far as their statements have any definite and tangible meaning, must mean that all existing languages stand in relation to the hypothetical primitive language very much as French and Italian stand in relation to Latin, or English and German to Old Teutonic, or Latin and Old Teutonic to Old Aryan. But in 


\section{A PRIMEVAL MOTHER TONGUE}

point of fact the case is very different from this. We know that French and Italian are differently modified forms of Latin, because we can trace the modern words directly back to their ancient prototypes, and verify by the aid of written documents their various changes of form and meaning. After carrying on for a while this process of comparison, we find that the modern words vary from the ancient according to certain well-defined rules, which are different for French and Italian, but are singularly uniform for each language. So unmistakable is the regularity of the system of changes, that if all record of Latin were to be swept away we might still reconstruct the language from a comparative study of its modern descendants. Mois and mese, for example, the French and Italian words for "month," would give us the Latin mensis, and nothing else; and so on throughout. In similar wise, although the Old Aryan language has left no written documents to tell us of its grammar and vocabulary, we have nevertheless detected such a regular system of phonetic changes among the languages which have descended from it that we have been already enabled to go some way toward reconstructing this extinct tongue. Month and mensis, for example, carry us back, with little less than absolute certainty, to an Old Aryan mansa; and so on as before, though here the inquiry is an abstruse 


\section{EXCURSIONS OF AN EVOLUTIONIST}

one, requiring patience and sound judgment, and there is room enough for doubt in many cases. The general relationship of the Aryan languages to their common ancestor is, however, no less clearly manifest than that of the modern Romanic languages to the Latin. After fifty years of such comparative study, in a cautious and prudent way, we have succeeded in making out some few cases of demonstrable genetic kinship among groups of languages. Beside the Aryan family, in the study of which such profound knowledge has been obtained, we have clearly made out the existence of the Dravidian family in Southern India, and of the Altaic family, - to which the Finnish, Hungarian, and Turkish belong, - to say nothing of the longestablished Semitic family. Other families of speech no doubt exist, and will by and by have their relationships definitely marked out. But the moment we try to compare these families with each other, in order to detect some definable link of relationship between them, we are instantly baffled. Any true family of languages will show a community of structure as conspicuous as that which is seen among vertebrate animals. The next family you study will be as distinctly marked in its characteristics as is the group of articulated insects, spiders, and crustaceans. But to compare the two families with each other will prove as futile as to compare a 


\section{A PRIMEVAL MOTHER TONGUE}

reindeer with a lobster. The only conclusion to which you can logically come is that while certain languages, here and there, have become variously modified, so as to give rise to welldefined families of speech, the like process has not taken place universally. In other words, the derivation of a dozen languages from a common ancestor is not a permanent and universal, but a temporary and local phenomenon in the history of human speech, and we need not expect to come across any such fact of derivation, except where it can be duly accounted for by the peculiar circumstances of the case.

This conclusion is reinforced when we consider the circumstances under which a single language gives rise to several mutually resembling descendants. Obviously such a language must have a high degree of permanence and a wide extension. It must be spoken for a long time by large bodies of men spread over a wide territorial area. Take, for example, the rise of the modern Romanic languages from the Latin. In the fourth century after Christ the Latin language was spoken all over the Italian and Spanish peninsulas, throughout most of Gaul and Switzerland, along the banks of the Upper Danube, and in what are now called the Rumanian principalities. In all these countries Latin was the speech in which the ordinary affairs of life were transacted, and this had come to be so mainly because the 


\section{EXCURSIONS OF AN EVOLUTIONIST}

native dialects of these countries were numerous and uncultivated ; and as all were in close political and social connection with Rome, it was a much simpler matter for all to learn Latin than for the Romans and their subjects alike to learn a score of barbarous tongues. The business of life got more easily transacted in this way. No such result followed the conquest of the Eastern world, because Greek was spoken all over the East, and every educated Roman knew Greek already; so that in this case it was a simpler matter for the conquerors to talk Greek than for their subjects to learn Latin. Practical convenience is the final arbiter in pretty much all such cases. Now it must not be supposed that the Latin talked all over the West was quite like the elegant language of Cæsar and Virgil. It was only educated people in Rome or Milan, and perhaps in such cities as Nismes or Lyons, that talked like this. Colloquial Latin always had plenty of dialectic peculiarities. Even in Italy the Latin had supplanted, in former times, a number of kindred Umbrian and Sabine dialects, and we may be sure that all these left their mark upon the common speech. In getting diffused over Europe, this impure colloquial Latin could not fail to pick up here and there some peculiar word or phrase, while now and then some other word or phrase would be lost from its old stock and forgotten, so that people did not talk 


\section{A PRIMEVAL MOTHER TONGUE}

just alike throughout the empire. A Spaniard's local peculiarities of utterance and phraseology were distinguishable from those of a Rhætian, though both talked Latin and could understand each other.

Now as every language changes more or less from age to age, so the speech of the Romans in the fourth century after Christ had come to differ in many respects from the speech of their forefathers who, six hundred years earlier, had fought against Hannibal. But up to this time the intercourse between the various parts of the Roman world had been so close and continuous that the capital still furnished the standard of discourse for the whole empire. During the next six centuries a different set of circumstances was at work. For a second time the Latin language was learned by scores of barbarous tribes, but this time it was no longer Rome that set the fashion and maintained the standard. In innumerable provincial towns and barbaric assemblies new standards of speaking were gradually established. The lines of connection, administrative and commercial, which had formerly been kept up, were in many cases severed, and each little tract of country led a more sequestered life than before. Many new expressions came into use, - Teutonic in Gaul and Italy, Arabic in Spain, Slavic in Rumania; and local idioms and peculiarities of accent multiplied, in the absence 


\section{EXCURSIONS OF AN EVOLUTIONIST}

of a uniform standard. In this way the vulgar Latin insensibly diverged into a host of provincial dialects, or patois, the divergence being great or little according to the frequency of intercourse between different localities. Thus the Tuscan and the Savoyard could both understand the Milanese, the inhabitant of Lyons could talk with the Savoyard and with the citizen of Orleans, and the Orleanese would be intelligible to the Parisian; while, on the other hand, the Parisian could hardly carry on a conversation with the Savoyard, and would be quite incapable of understanding the Tuscan. Some such slowly graded transition may still be noticed by the traveller from France to Italy who takes pains to observe the speech of the common people. At Nice, for instance, local newspapers are published in a dialect which one hardly knows whether to call French, Provençal, or Italian.

After this process of divergence had gone on for some time, a new start was taken toward uniformity, but in such a way as to enhance and complete the divergence already begun. When literary men gave up trying to write classical Latin, and began to clothe their thoughts in the colloquial Romance or vulgar tongue of the times, new centres of political and intellectual life had begun to be formed at Paris, Toulouse, and Florence; and the dialects of these cities began to assume preëminence as literary and 


\section{A PRIMEVAL MOTHER TONGUE}

fashionable dialects. As southern France came more and more under the sway of Paris, the second of these centres indeed lost its relative importance, and the Provençal tongue gradually sank into an unfashionable patois; but Parisian and Tuscan, on the other hand, came to be so generally read and spoken that after a while they quite crowded their intermediate sister dialects out of sight, and to-day they are the sole recognized representatives of good French and good Italian speech, although there is still a great deal of French spoken that is not Parisian, and a great deal of Italian that is not Tuscan. This predominance of the two central dialects is in our day increasing more rapidly and decisively than ever before, and the process will unquestionably go on until all Frenchmen speak Parisian, and all Italians speak Tuscan. Railroads and telegraphs, newspapers and novels, have already sealed the death-warrant of all patois, and the execution is only a question of time. It is because of the wide diffusion in our own country of these powerful agencies for keeping men in contact with each other that we have no varieties of dialect here worth speaking of. It is not at all likely that in this country such dialectic variations will ever spring up. And for the same reason it is not likely that any essential divergence will ever arise between the English language as spoken in England and the 


\section{EXCURSIONS OF AN EVOLUTIONIST}

same language as spoken in America. In the Middle Ages, wolves, brute and human, taxgatherers and robber barons, as well as bad roads and imperfect vehicles, made a few miles of wood or mountain a greater barrier to intercourse than the wide ocean is to-day. For the language of the thriving people to whom, as to the ancient

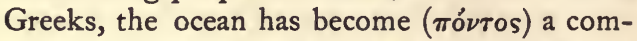
mon "pathway;" who have taught mankind how to drive ships with steam, and how to send electric flashes of intelligence through the watery abyss, - for this language a future of unprecedented glory is in store. By the end of the twentieth century, English will no doubt be spoken by something like eight hundred million people, crowding all over North America and Australia, as well as over a good part of Africa and India, with island colonies in every sea and naval stations on every cape. By that time so large a proportion of the business of the world will be transacted by people of English descent that, as a mere matter of convenience, the whole world will have to learn English. Whatever other language any one may have learned in childhood, he will find it necessary to speak English also. In this way our language will become more and more cosmopolitan, while all others become more and more provincial, until after a great length of time they will probably one after another assume the character and incur 
the fate of local patois. One by one they will become extinct, leaving English as the universal language of mankind.

There is, I think, a considerable probability that things will come to pass in this way, though the process must of course be a very slow one, and the result here prefigured will very likely come so far down in the future as to coincide with the disappearance of barbarism from the earth, and with the inauguration of that pacific "parliament of man" of which the philosophic poet has told us. But, however the actual result may shape itself in its details, the considerations here brought forward would seem to indicate that complete community of speech belongs rather to the later than to the earlier stages of human progress. What we may regard as certain is that community of speech on a wide scale requires prolonged and continuous business communication among large bodies of men. Where communication is seriously interrupted for a long period of time, as in the Dark Ages of Europe, the tendency is for the common language to break up into a number of more or less similar dialects; and in proportion as frequent communication is resumed there is manifested an opposite tendency of a few central dialects to crush out their neighbours, and to grow into wide-spread languages. This is, in brief, the way in which languages grow, and diverge, 
and supplant one another. There is nothing that is mysterious or metaphysical in the process; it is purely a matter of practical convenience. In the long run the actions of man are determined by what we may call the "law of least effort:" the easiest way of doing things is the one which, sooner or later, is sure to be adopted; and to this general law the myriad little actions involved in speech form no exception.

Carrying back to ancient times the lessons we have learned from the career of Latin, we find that the facts, so far as known, sustain our conclusion. Among the Semitic peoples there was undoubtedly a time when all were of one blood and one speech. No one doubts that Arabs, Jews, and Syrians are as closely related by descent as Germans, Swedes, and Englishmen. The social condition of these Semitic races, shortly before the historic period, is best represented by the wandering Arabs of the present day. In this patriarchal stage of society there is no such close political cohesion as there is among nations of modern type, but there is frequent intercourse for business purposes, and even sometimes for purely literary objects, as in the old competitions of bards at Mecca before the time of Mohammed; and this intercourse has sufficed to preserve the main features of the language. In early times there was sufficient communication between the patriarchal tribes of 146 


\section{A PRIMEVAL MOTHER TONGUE}

Arabia and Palestine and the adjacent civilized nations of Assyria, Babylonia, and Phœnicia to prevent any very wide divergence of speech. The differences between Hebrew, Syriac, and Assyrian are not greater than the differences between French, Spanish, and Italian.

So, too, in the direct line of our own ancestry, we find that the primitive Aryans were a race partly agricultural and partly pastoral in pursuits, living in durable houses, grouped together into large villages, surrounded by defensible walls. The structure of the family was somewhat cruder than among the patriarchal Arabs and Hebrews; the social and political system may have been in some respects such as we see vestiges of to-day in the village communities of Russia and Hindustan. Preëminent among all early races in the rearing of flocks and herds, the old Aryans required immense grazing grounds, and would seem to have occupied all the wide grassy plains which lie between the mountains of central Tartary and the southern slopes of European Russia. At the same time their agricultural pursuits and their durable villages imply a considerable amount of political stability, and there is good evidence that for a long time a common language was spoken throughout this vast territory. As we follow these Aryan tribes in their great career of permanent conquest and settlement, one branch 


\section{EXCURSIONS OF AN EVOLUTIONIST}

into Persia and India, and other branches into Greece, Italy, Germany, Gaul, and Britain, we come upon the same linguistic phenomena which we observed above in the mediæval history of Latin. With the isolation of the various tribes, separated from each other by wide distances, we see the Aryan mother tongue break up into innumerable dialectic forms; until, by and by, with the rise of new and distinct centres of social life, new and distinct languages come upon the scene, and acquire literary immortality in the Vedas, in the Avesta, in the epics of Homer and Virgil, in the novels of Cervantes and Turgenief, in the sermons of Bossuet and Taylor, in the dramas of Shakespeare and Goethe, and in that palladium of linguistic stability in the future, - the English version of the Bible.

In such cases as these, where a single durable mother language has produced several durable offspring, the signs of kinship, whether in grammar or in vocabulary, are never obliterated. After an independent career of more than ten centuries, the genetic relationship of French and Italian is a perfectly patent fact, about which there could be no question whatever, even if all memory of the Roman Empire had lapsed from men's minds, even if some fanatical Cardinal Ximenes had burned in a bonfire every scrap of French and Italian literature that ever existed. After an independent career of not less than forty 


\section{A PRIMEVAL MOTHER TONGUE}

centuries, the kinship of Latin and Sanskrit is equally unmistakable. It is not an occult fact, which discloses itself only after a subtle philological analysis; it is a fact so plain that no one who reads Sanskrit and Latin books can possibly overlook it, and it forced itself upon the attention of the first European scholars who studied Sanskrit in the seventeenth century, though they knew nothing of philological analysis as we understand it. The similarity between the long-known Hebrew and the lately deciphered Assyrian is no less conspicuous; and the same may be said of the Dravidian languages of southern India when compared with one another.

But as we leave this circle of studies, and venture out into the wilderness of barbaric speech, we find a very different state of things. The northern portions of Asia have been inhabited, within the period of history, by three different races, all of whom still survive, - the Finno-Tataric, the Mongolian, and the Samoyedic races. The linguistic relationships of these peoples are very instructive. In the first place, the Finno-Tataric peoples appear to belong to the same white race from which the Aryans and the Semites have diverged, although there is nothing remotely resembling Aryan or Semitic in Finno-Tataric speech. This family of languages is represented in Europe by the Finnish and its neighbouring dialects, by the 


\section{EXCURSIONS OF AN EVOLUTIONIST}

Hungarian, and by the Turkish. In Asia it is represented by a great number of languages, spoken in the Caucasus, in Turkistan, and in Siberia. Eastward of this vast region comes the Mongolian or yellow race, with which we should be very careful not to confound the Tatars. There has always been a great deal of confusion of nomenclature in speaking of these races, but the lines of distinction are really simple enough when we have once learned them. The ambiguous word which is responsible for most of the confusion is the epithet Tatar, which did originally belong to the Mongols, but has come to be applied by preference to the Turkish family. When Jinghis Khan, in the thirteenth century, made the name Tatar a sign of terror and humiliation to all Asia and Europe, it became customary to apply this dreaded epithet to all the hordes that were subject to the Mongolian ruler, - changing the word slightly to "Tartar," so as to add to it a mild flavour of the bottomless pit, in allusion to the general behaviour of those ugly customers. As most of these hordes with which Europeans came into contact were really of white or Turkish race, the name Tatar became gradually appropriated to these, and thus became unfit for distinguishing the yellow Mongolians. All ambiguity would be avoided if we were to drop the name Tatar altogether, and substitute the 


\section{A PRIMEVAL MOTHER TONGUE}

name Turk for the whole group of peoples of which the Ottomans are the most conspicuous. Our school atlases already have "Turkistan" instead of the old-fashioned "Independent Tartary."

The Mongolian race comprises the yellow tribes of central Asia, from whom came Jinghis Khan, Timur, and the whole line of Mogul sovereigns of India; and also the Tungusians, or Mandshus, who for the last two centuries have ruled over China. The Chinese themselves, as well as the Japanese, must also be considered as branches of the Mongolian race. On the other hand, the Samoyeds of northern Siberia seem to be allied to our Eskimos, but not very obviously to the Mongolians.

The race divisions of the northern half of Asia are thus clear enough. First, we have the Finno-Tatars, or Finno-Turks, belonging to the dark-haired portion of the great white race; secondly, we have the Mongolians; thirdly, the arctic Samoyeds. But the languages spoken by these peoples cannot be classified in any such simple way. The languages of the Finns and Turks carry us back to two mother tongues, and these are possibly reducible to one. It is otherwise when we come to Mongolian speech. On the one hand, the Mongolian dialects of central Asia are strikingly similar in structure to the Tungusian languages, and also to the 


\section{EXCURSIONS OF AN EVOLUTIONIST}

Japanese; and in these structural peculiarities they agree also with the Finno-Turkic. On the other hand, when we study the vocabularies, we do not find any similarity, such as to suggest a primitive identity, between Japanese, Tungusian, and Mongolian proper. We are still further baffled when we come to Chinese. The people of Japan obtained their written character from China, modifying it to suit the needs of their own language; and so a Japanese printed page looks very like a printed page in Chinese. If you were just to look at these printed pages, you would imagine that the two languages are very similar, just as a Chinaman, on seeing Hungarian printed in the Roman character, would fancy that Hungarian must be similar to English or Latin. In reality no kinship has yet been detected between the languages of China and Japan. Not only in vocabulary does Chinese differ from all the other languages spoken by the Mongolian race, but it even presents a fundamentally distinct type of linguistic structure. Age after age, from the remotest antiquity to which historic or philologic inference can guide us, the Chinese have talked with different words and after a different grammatical fashion from their yellow neighbours; and these in turn have maintained each their distinct varieties of speech; although all these peoples - the inhabitants of Japan and 


\section{A PRIMEVAL MOTHER TONGUE}

China, the Tungusians, and the Mongols of central Asia - are undoubtedly united by physical bonds of descent from one and the same primeval yellow race.

The inference from this is that there never was a primitive Mongolian mother tongue in the sense in which there was a primitive Aryan mother tongue. The common ancestors of Japanese, Chinese, Tungusian, and Mongol never at any time lived together in one great society, welded into a unit by community of language, traditions, and customs, as was the case with the common ancestors of Roman, Teuton, and Hindu. On the contrary, the aboriginal yellow men must have roamed about in detached tribes, like the blacks of Australia or the red men of America, with half-formed languages fluctuating from generation to generation, diverging with great rapidity, and speedily losing all traces of their origin. Ensconced within convenient mountain barriers, one series of these yellow tribes worked out its peculiar language and civilization in the rich hill-country and along the great navigable rivers of China. A second series of tribes, moving without reference to these, and at a very much later date, formed a permanent community in the islands of Japan. While the remainder of the race have led a nomadic life down to the present day; now and then engaging in combined activity for a gener- 


\section{EXCURSIONS OF AN EVOLUTIONIST}

ation or two, under the guidance of such adventurers as Attila, or Jinghis, or Timur, to become for a brief season the "scourge of God" and the terror of mankind, but ever, as now, incapable of stable political union. With such divergent careers as these, we need not expect to find evidence of linguistic community among the different branches of the yellow race. If we find one set of linguistic phenomena in China, and a totally different set in Japan, and yet another set among the barbarous Mongols and Tunguses, this is no more than we might have expected. We need not expect to find such phenomena as the coördinate divergence of French and Italian from a common Latin mother tongue, or of Latin and Sanskrit from a common Aryan mother tongue, except where we can find historical conditions similar to those under which these phenomena were manifested. Outside of that broad stream of history which includes the Aryan and Semitic worlds we do not find such conditions, save in a few sporadic cases. On the contrary, we find just such a state of things as would follow from the isolated independent development of a number of languages, either without any original kinship, or with the original kinship blurred and destroyed almost from the very beginning.

The last clause introduces us to a consideration concerning barbarous languages which is 


\section{A PRIMEVAL MOTHER TONGUE}

of the first importance. There is a certain sense in which we may admit community of origin for languages that are now quite dissimilar; but the sense is one that is foreign to philological usage, and has no real philological significance. No doubt all the yellow races of Asia are descended from some small group of yellow progenitors, and no doubt this ancestral group possessed the faculty of articulate speech. Most likely the group was at the outset small enough to use but one language, and as the group increased in size and became subdivided into a number of tribes, the common language would soon get broken up into dialects. So far very good; but what we have to notice is that under such circumstances the breaking up of the common language would not in any way resemble the breaking up of Latin into the dialects of France and Italy. On the contrary, the several dialects would change so rapidly as to lose their identity : within a couple of centuries it would be impossible to detect any resemblance to the language of the primitive tribe. The speech of uncivilized tribes, when not subject to the powerful conservative force of widespread custom or permanent literary tradition, changes with astonishing rapidity. Such languages usually contain but a few hundred words, and these are often forgotten by the dozen and replaced by new ones even in the course of a single genera- 


\section{EXCURSIONS OF AN EVOLUTIONIST}

tion. Among many South American Indians, as Azara tells us, the language changes from clan to clan, and almost from hut to hut, so that members of different families are obliged to have recourse to gestures to eke out the scanty pittance of oral discourse that is mutually intelligible. In the northern part of Celebes, " in a district about one hundred miles long by thirty miles wide, not less than ten distinct languages are spoken." I In civilized speech no words stick like the simple numerals : we use the same words to-day, in counting from one to ten, that our ancestors used in central Asia ages before the winged bulls of Nineveh were sculptured; and the change in pronunciation has been barely sufficient to disguise the identity. But in the language of Tahiti four of the ten simple numerals used in Captain Cook's time have already become extinct:-

"Two was rua; it is now piti.

Four was ha; it is now maha.

Five was rima; it is now pae.

Six was ono; it is now fene." 2

Out of many facts that might be cited, these must suffice. The facility with which savage tongues abandon old expressions for new has no parallel in civilized languages, unless it be in some of the more ephemeral kinds of slang. It

1 Müller, Science of Language, 6th ed. ii. 36.

2 Op. cit. 28. 


\section{A PRIMEVAL MOTHER TONGUE}

is sufficiently clear, I think, that under such circumstances a language will seldom or never acquire sufficient stability to give rise to mutually resembling derivative dialects. If the habits of primitive men were in general similar to those of modern savages, we need not be surprised that philologists are unable to trace all existing languages back to a common origin. In order to get back to a universal mother tongue, it would almost seem requisite that the history of mankind should have begun with universal empire.

We shall conclude, I think, after a survey of the whole matter, that in speech, as in other aspects of social life, the progress of mankind is from fragmentariness to solidarity; at the beginning, a multitude of feeble, mutually hostile tribes, incapable of much combined action, with hundreds of half-formed dialects, each intelligible to a few score of people; at the end, an organized system of mighty nations, pacific in disposition, with unlimited reciprocity of intercourse, with very few languages, rich and precise in structure and vocabulary, and understood by all men.

December, 1877. 


\section{VI}

\section{SOCIOLOGY AND HERO-WORSHIP}

T $\mathrm{N}$ his interesting article entitled "Great Men, Great Thoughts, and the Envi1 ronment," published in "The Atlantic Monthly" for October, I880, Dr. William James calls attention to the striking analogy between "geniuses" and what are known to modern zoölogists as "spontaneous variations." Nothing could be more satisfactory than the manner in which (on pages 444-447) Dr. James expounds the nature of this analogy, and emphasizes the truly philosophic character of $\mathrm{Mr}$. Darwin's method of dealing with so-called spontaneous variations. The analogy between those variations, on the one hand, of which the zoölogist takes cognizance, and on the other hand those "sociological variations" known as geniuses or "great men," consists essentially in the similarity of causal relations in the two cases. Both kinds of variations may be described as deviations from an average which are severally unaccountable. Every species of animals or plants consists of a great number of individuals, which are nearly but not exactly alike. Each 


\section{SOCIOLOGY AND HERO-WORSHIP}

individual varies slightly in one characteristic or another from a certain type which expresses the average among all the individuals of the species. Thus, if one inch be the average length of the proboscis of a certain species of moth, it may well be that of the million individuals which make up the species the great majority have the proboscis a little shorter or a little longer than an inch: in most instances the deviation may not exceed a hundredth or a thousandth part of an inch; but there may be half a dozen individuals in the species which have the proboscis as long as two inches or as short as half an inch. So, the average height of men in the United States may be about five feet and eight inches, very few men being shorter than five feet and four inches, or taller than six feet; yet in the side-tents which accompany that "great moral exhibition," the circus, one may, for a quarter of a dollar, see giants eight feet in height, or dwarfs like General Tom Thumb. It is just the same with men's intellectual capacities as with their physical dimensions, though the one cannot exactly, like the other, be measured with a foot-rule. In every community of men and women there is a certain average standard of mental capacity; which, in the case of a progressive race like ours, may be roughly described as that degree of ability to meet the complicated exigencies of civilized life which 


\section{EXCURSIONS OF AN EVOLUTIONIST}

will leave the next generation somewhat better equipped than their parents for meeting these exigencies. Those men whom we regard as conspicuously successful in life - using the term "successful" in no narrow and mercantile, but in the broadest possible sense - are the men, more or less numerous, whose mental capacity rises somewhat above this average standard. A like number of men, through various kinds and degrees of ill success, reveal a mental capacity that is more or less below the average. And along with these numerous moderate variations from the common level we meet in every age with a few extreme variations, - men of giant intelligence, such as Darwin or Helmholtz, who rise as far above the average of the race as idiots and cretins sink below it.

Now the moth with his proboscis twice as long as the average, or the man eight feet in height, is what we call a spontaneous variation, and the Darwin or the Helmholtz is what we call a "genius;" and the analogy between the two kinds of deviation is obvious enough. But obviously, too, the individual which we single out as a spontaneous variation is in no wise essentially different from his fellow-individuals. If five feet and eight inches be the normal height of a race of men, the man who measures six feet is a variation as much as he who measures eight, - only the one instance does not attract 


\section{SOCIOLOGY AND HERO-WORSHIP}

our attention, and the other does. In any species whatever, the greater number of individuals are no doubt variations, either in one respect or in another. Throughout nature, where a great number of mutually balancing forces coöperate to produce a set of results, we are likely to find the results distributed about a certain average, very much like the shots at a target. A little way from the centre there is a spot where the shots are thickly gathered; some few have hit the bull's-eye; some have been caught away out on the rim; some have perhaps flown by without hitting at all. It is just the same with the distribution of sizes, strengths, forms, or any attributes, physical or mental, in a species of animals, or in a race of men. These things all differ, according to the general laws of deviation from an average; and the forces concerned in the result are so hopelessly complicated - it is so utterly beyond our power to unravel them - that this is all we know about the matter. We cannot tell why a given moth has a proboscis exactly an inch and a quarter in length any more than we can tell why Shakespeare was a great dramatist.

I agree, therefore, with Dr. James, that " the causes of production of great men lie in a sphere wholly inaccessible to the social philosopher. He must simply accept geniuses as data, just as Darwin accepts his spontaneous variations." I6I 


\section{EXCURSIONS OF AN EVOLUTIONIST}

The problem of the social philosopher, undoubtedly, so far as he speculates about the influence of great men, is to take them for granted, and inquire how far they affect the environment, and how far or in what ways the environment affects them. Dr. James goes on to assert, with entire justice, that the relation of the environment to the genius in sociology is strictly analogous to the relation of the environment to the variation in biology: "it chiefly adopts or rejects, preserves or destroys, in short selects him." If environing circumstances are such as to render an extra quarter of an inch of proboscis advantageous to our species of moths, then the tendency will be for the variations in excess of length of proboscis to survive and leave offspring, while the variations in the opposite direction are starved out; so that by and by the average in the length of proboscis will have been shifted by a quarter of an inch. It may be truly said, in a certain sense, that these moths which have varied in the right direction have, by being preserved, changed the character of the moth society to which they belong. Similarly with the preservation of the great man, save that, in the immensely greater complexity of the social problem, the effects are immeasurably more multifarious. For the great man, says Dr. James, acts as a powerful ferment, unlocking vast reservoirs of force in various directions, 


\section{SOCIOLOGY AND HERO-WORSHIP}

and thus alters the whole character of his environment, very much as the introduction of a new species may alter the characters and relations of the fauna and flora throughout a whole neighbourhood. Dr. James concludes, then, that "the mutations of societies from generation to generation are in the main due directly or indirectly to the acts or the example of individuals whose genius was so adapted to the receptivities of the moment, or whose accidental position of authority was so critical, that they became ferments, initiators of movement, setters of precedent or fashion, centres of corruption, or destroyers of other persons, whose gifts, had they had free play, would have led society in another direction."

I am careful to emphasize these conclusions of Dr. James, because, as far as they go, they are my own, and, I believe, are in general the views of that "Spencerian or evolutionist school " toward which Dr. James seems to cherish such an intense antipathy. Perhaps I may not be quite clear as to what the Spencerian "school" may be. One characteristic of thinkers of such calibre as Mr. Spencer is that they do not so much found schools as bring about a shifting of the intellectual standpoint and an enlarging of the intellectual horizon for the whole contemporary world. The ideas of which Mr. Spencer is the greatest living exponent are to-day running like 163 


\section{EXCURSIONS OF AN EVOLUTIONIST}

the weft through all the warp of modern thought, and out from their abundant suggestiveness have come the opinions of many who do not profess any especial "allegiance" to Mr. Spencer, of many, even, who are inclined to scoff at the teacher, while all unconscious of the debt they owe him. But while I cannot undertake to make confident assertions as to the views of a Spencerian school, I think I may venture to speak with some confidence as to the attitude of Mr. Spencer himself toward the present question.

So far is Dr. James from realizing how closely he has been following in Mr. Spencer's own line of thought that he begins his paper by seeking to use a certain alleged opinion of $\mathrm{Mr}$. Spencer as a "foil " whereby to set off and illustrate the truth of his own statements. The problem before us is, "What are the causes that make communities change from generation to generation, - that make the England of Queen Anne so different from the England of Elizabeth, the Harvard College of to-day so different from that of thirty years ago ?" Dr. James replies, "The difference is due to the accumulated influences of individuals, of their examples, their initiatives, their decisions." Very good. When taken with the proper qualification - which I shall presently specify - there is nothing in this reply to which Mr. Spencer

$$
164
$$


need offer an objection. But according to Dr. James the Spencerian school holds that "the changes go on irrespective of persons, and are independent of individual control. They are due to the environment, to the circumstances, the physical geography, the ancestral conditions, the increasing experience of outer relations; to everything, in fact, except the Grants and the Bismarcks, the Joneses and the Smiths."

Now if "Mr. Herbert Spencer and his disciples" really maintain any such astonishing proposition as this, it must be difficult to acquit them of the charge of over-hasty theorizing, to say the least; if they do not hold any such view, it will be difficult to avoid the conclusion that somebody has been guilty of over-hasty assertion. To ascertain Mr. Spencer's own opinion, one cannot do better than to read carefully the third chapter of the little book on the "Study of Sociology." The subject of this chapter is the "Nature of the Social Science," and the first general conclusion arrived at is that this science " has in every case for its subjectmatter the growth, development, structure, and functions of the social aggregate, as brought about by the mutual actions of individuals, whose natures are partly like those of all men, partly like those of kindred races, partly distinctive." After this lucid statement, which in its triple specification seems comprehensive enough to include the 


\section{EXCURSIONS OF AN EVOLUTIONIST}

Grants and Bismarcks, as well as the Joneses and Smiths, Mr. Spencer goes on to say, "These phenomena of social evolution have of course to be explained with due reference to the conditions each society is exposed to, - the conditions furnished by its locality, and by its relations to neighbouring societies. Noting this merely to prevent possible misapprehensions, the fact which here concerns us is that ... given men having certain properties, and an aggregate of such men must have certain derivative properties which form the subject-matter of a science."

A deliberate and methodical statement like this, forming the burden of half the chapter in which Mr. Spencer lays out the ground for his work, must of course be received as an authoritative expression of his opinion. It will be observed that Mr. Spencer takes precisely the same position as that which is taken by Dr. James when he says that the changes which go on in society are "due to the accumulated influences of individuals, of their examples, their initiatives, their decisions." So decidedly does Mr. Spencer put himself in this position that it occurs to him that he may possibly be misinterpreted as ignoring the influence of environing conditions, and he therefore adds the qualification that in interpreting social changes we must make " due reference" to the outward conditions to which so- 


\section{SOCIOLOGY AND HERO-WORSHIP}

ciety is exposed. Not even Mr. Spencer's wide experience of the infinite possibilities of misconception could have led him to suspect that in this instance he might be charged with ignoring the individual Smiths and Joneses of whom society is composed!

This due reference to surrounding conditions is the qualification to which I alluded a moment ago as necessary to give completeness to Dr. James's statement. When we say that the difference between the England of Queen Anne and the England of Queen Elizabeth is due to the accumulated influence of the initiatives and decisions of individuals, to what initiatives and decisions do we refer? Certainly not to the abortive ones; not to those initiatives and decisions that had been promptly crushed out or held in check, but to those that had been allowed to develop and fructify in the great events which make up the English history of the seventeenth century. In other words, we refer to those individual initiatives and decisions which had been selected for preservation by the aggregate of the conditions in which English society at that time was placed. So that, even in stating the case as Dr. James states it, we find ourselves unable to get along without tacit reference to the environment.

It is true that in regarding the changes of society from age to age as due to the cumulative 167 


\section{EXCURSIONS OF AN EVOLUTIONIST}

effect of individual actions in relation to environing conditions, one may nevertheless deal with the subject practically in more than one way. One writer may turn his attention chiefly to the consideration of those individual variations in opinion and conduct which, in our ignorance concerning their complex modes of genesis, we call spontaneous variations. Another writer may be more deeply interested in pointing out such circumstances as those of geographical position, of commercial intercourse, of political cohesiveness, by which the broad outlines of history have been more or less determined. The two points of view seem to me complementary rather than opposed to each other, though it is a common fault among speculative writers to ignore the existence of all the doors that cannot be unlocked with their own particular little key. Mr. Bagehot - in that "golden little book" which I admire as much as Dr. James does - deals more especially with the interior or psychical aspects of the causes of changes in society. Mr. Grant Allen, on the other hand, is deeply impressed with the manifold and remarkable ways in which the histories of nations have been affected by their geographical position; though by "geographical position" he means something far more considerable than that household drudge of superficial writers, the climate: he means the entire situation of a nation, strategic, industrial. 


\section{SOCIOLOGY AND HERO-WORSHIP}

commercial, and literary, in relation to other nations. Mr. Allen attaches so much value to considerations of this kind that he is led to stigmatize Mr. Bagehot's method as unscientific and unfruitful in good result. Mr. Bagehot, as a thinker of more catholic mind, would hardly, I believe, have been equally ready to undervalue Mr. Allen's work. As explanations after the fact - which are pretty much the only kind of explanations we can expect to have where the concrete events of history are concerned - speculations like those of Mr. Allen are extremely interesting and suggestive. I agree in the main, however, with Dr. James in his views as to the inadequacy of Mr. Allen's method. It is no doubt true that " no geographical environment can produce a given type of mind; it can only foster and further certain types, ... and thwart and frustrate others." No doubt, too, Mr. Allen makes a very extravagant statement when he says that " if the people who went to Hamburg had gone to Timbuctoo they would now be indistinguishable from the semi-barbarian negroes who inhabit that central African metropolis; and if the people who went to Timbuctoo had gone to Hamburg they would now have been white-skinned merchants driving a roaring trade in imitation sherry and indigestible port." In reading such a statement as this, one seems, indeed, to have fallen upon pre-Darwinian days: 


\section{EXCURSIONS OF AN EVOLUTIONIST}

nay, more, one wonders whether Mr. Allen has ever studied as carefully as he ought to have done the biological teachings of Mr. Spencer whose opinions Dr. James quotes him as representing !

Mr. Allen has brilliantly illustrated several points in connection with the doctrine of evolution, more especially in the department of psychology; but there is no good reason why he should be selected for quotation as the representative of all Spencerian evolutionists, or why all Spencerian evolutionists should be held responsible for Mr. Allen's peculiar opinions. The only connected outline of Spencerian sociology as yet in existence (save what has been published by Mr. Spencer himself) is that which is contained in the second volume of my "Outlines of Cosmic Philosophy." That the opinions therein expressed harmonize in the main with Mr. Spencer's I have the strongest possible reasons for asserting. Yet the line of thought followed in this part of my work, and especially in the chapter on "Conditions of Progress," is far more closely parallel with Mr. Bagehot's line of thought than with Mr. Allen's. Separate passages might be cited to the same effect; as, for example, where it is said (vol. ii. p. I 99) that the ecclesiastical reforms of Gregory VII. have - in their remote results, of course - had more influence upon American history than the di- 


\section{SOCIOLOGY AND HERO-WORSHIP}

rection of the Rocky Mountains or the position of the Great Lakes. On the next page, alluding to Mr. Buckle's theory that the difference in Arabian civilization before and after the time of Mohammed was due to the difference between the soil of Arabia and that of Spain, Persia, and India, I say, " To exhibit the utter superficiality of this explanation, we have only to ask two questions : First, if the Arabs became civilized only because they exchanged their native deserts for Spain, Persia, and India, why did not the same hold true of the Turks when they exchanged their barren steppes for the rich empire of Constantinople? Though they have held for four centuries what is perhaps the finest geographical position on the earth's surface, the Turks have never directly aided the progress of civilization. Secondly, how was it that the Arabs ever came to leave their native deserts, and to conquer the region between the Pyrenees and the Ganges? Was it because of a geologic convulsion? Was it because the soil, the climate, the food, or the general aspect of nature had undergone any sudden change? One need not be a profound student of history to see the absurdity of such a suggestion. It was because their minds had been greatly wrought upon by new ideas; because their conceptions of life, its duties, its aims, its possibilities, had been revolutionized by the genius of Mohammed. The 


\section{EXCURSIONS OF AN EVOLUTIONIST}

whole phenomenon requires a psychological, not a physical, explanation." And again (vol. ii. p. 237), in speaking of Comte, - a writer whose views of history were sometimes profound, though his philosophic position was diametrically opposite to that of $\mathrm{Mr}$. Spencer and the evolutionists, - I say, " $\mathrm{He}$ did not fall into the error that individual genius and exertion are of little or no account in modifying the course of history. He did not forget that history is made by individual men, as much as a coral reef is made by individual polyps. Each contributes his infinitesimal share of effort; nor is the share of effort always so trifling. Considering the course of history merely as the resultant of the play of moral forces, is there not in a Julius Cæsar or a Themistokles as large a manifestation of the forces which go to make history as in thousands of common men?"

These views of mine, as being the opinions of a "disciple" of Mr. Spencer, may perhaps be set off against those which Dr. James quotes from Mr. Allen. They seem to me to be quite in harmony with the whole spirit of Mr. Spencer's philosophy, ${ }^{1}$ but it would be very difficult to find, anywhere in Mr. Spencer's writings, anything that would serve as a justification for Mr. Allen's extraordinary statement about the

I have since been assured by Mr. Spencer that I have throughout this argument correctly represented his position. 


\section{SOCIOLOGY AND HERO-WORSHIP}

Timbuctoo negroes and the merchants of Hamburg.

Dr. James, however, does quote from $\mathrm{Mr}$. Spencer one passage which seems to him to ignore or to underrate the importance of individual initiative as an agent in the production of social changes. But when carefully considered in connection with its context, this passage does not appear to be responsible for the direful corollaries which Dr. James has deduced from it. Commenting on the "great-man theory" of history, especially as held by Carlyle, Mr. Spencer reiterates in his peculiar language the familiar criticism that after all the great man is a " product of the age." "The genesis of the great man," says he, "depends on the long series of complex influences which has produced the race in which he appears, and the social state into which that race has slowly grown. . . . All those changes of which he is the proximate initiator have their chief causes in the generations he descended from." In saying this, Mr. Spencer does not imply that the individual initiative of the great man is of no account; nor does he imply that in order to interpret the social phenomena of a given epoch it is needful to seek for the causes of the production of its great men in that physiological sphere "which is wholly inaccessible to the social philosopher;" nor does he imply that it was owing to any " con- 


\section{EXCURSIONS OF AN EVOLUTIONIST}

vergence of sociological pressures" in the England of 1564 that a "W. Shakespeare, with all his mental peculiarities," happened to be born at Stratford-on-Avon, in that year. In some of those omitted sentences of the passage cited which Dr. James represents by dots, Mr. Spencer indicates very clearly what he means. He reminds us that by no possibility could a Newton be born of Hottentot parents, or an Aristotle "come from a father and mother with facial angles of fifty degrees ; " and further that, even supposing it possible for a Watt to be born in a tribe unacquainted with the use of iron, his inventive genius would be likely to effect but little. Dr. James himself alleges parallel truths : as that after a Voltaire you cannot have a Peter the Hermit, or that under the social conditions of the tenth century a John Stuart Mill would have been impossible.

Now the bearing of these considerations upon the question which Mr. Spencer is discussing is obvious. If it be true that a genius of a given kind can appear under certain social conditions, and not under others, as a Newton among civilized Englishmen, but not among Hottentots; or if it be true that a given genius can work out its results under certain social conditions, and not under others, as a Mill in the nineteenth century, but not in the tenth; then it follows that in order to understand the course of history 


\section{SOCIOLOGY AND HERO-WORSHIP}

from age to age the mere study of the personal characteristics and achievements of great men is not sufficient. Carlyle's method of dealing with history, making it a mere series of prose epics, has many merits, but it is nevertheless, from a scientific point of view, inadequate; it does not explain the course of events. History is something more than biography. Without the least disrespect to the memories of the great statesmen of Greece and Rome, it may safely be said that one might learn all of "Plutarch's Lives" by heart, and still have made very little progress toward comprehending the reasons why the Greek states were never able to form a coherent political aggregate, or why the establishment of despotism at Rome was involved in the conquest of the Mediterranean world. The true way to approach such historical problems as these is not to speculate about the personal characteristics of Lysander or C. Gracchus, but to consider the popular assemblies of the Greeks and Romans in their points of likeness and unlikeness to the folkmotes and parliaments of England and the town meetings of Massachusetts. Since the middle of the nineteenth century the revolution which has taken place in the study of history is as great and as thorough as the similar revolution which, under Mr. Darwin's guidance, has been effected in the study of biology. The interval in knowledge which sepa- 


\section{EXCURSIONS OF AN EVOLUTIONIST}

rates a Freeman in 1880 from a Macaulay in I 850 is as great as the interval which separated Dalton and Davy from the believers in phlogiston. Yet in the principal works by which this immense change has been brought about - such as the works of Maine and Stubbs, Coulanges and Maurer - biography plays either an utterly subordinate part or no part at all.

Now the passage on the great-man theory, which Dr. James quotes from Mr. Spencer, is a protest against the alleged adequacy of the method of Carlyle. Important as the "great man" may be, it is not his individual thoughts and actions which primarily concern the sociologist. The truths with which sociology primarily concerns itself are general truths relating to the structure of society and the functions of its various parts; and they are obtained from a comparative and analytical survey of the actions of great masses of men, considered on a scale where all matters of individual idiosyncrasy are averaged, and for the purposes of the inquiry eliminated. Such questions as relate to the structure of the family in different stages of civilization, to the relations of the various classes of society to the governing body, to the circumstances which hinder or favour the aggregation of tribes into nations, - it is such problems as these that mainly concern the student of sociology ; and into such problems biographical con- 


\section{SOCIOLOGY AND HERO-WORSHIP}

siderations do not enter, any more than they enter into the study of political economy. Political economy deals with the actions of men in great masses in so far solely as the production and distribution of wealth are concerned, and its conclusions remain equally true, no matter whether a genius or a dunce presides over the national finances. That a protective tariff is an indirect tax levied upon an entire community, for the personal benefit of a few members of the community, is an economical truth that is quite independent of the particular financial schemes or legislative acts of particular great men. So - to take one from that class of facts in political history with which the student of sociology is especially concerned - it is very clear that if a primary assembly, like the $\mathrm{New}$ England town meeting, is confined within narrow geographical limits, so that people can easily attend to it, it will be likely to remain a folkmote, or primary assembly; but if it is spread over a wide area, so that people cannot conveniently come to the meetings, it will tend either to shrink into a witanagemote, or assembly of notables, or to develop into a representative assembly. This is a proposition derived from our general experience of the way in which people behave under given conditions, and confirmed by a wide historical induction. Yet the implications of this simple proposition, when once fully 


\section{EXCURSIONS OF AN EVOLUTIONIST}

unfolded, will go farther toward explaining the differences between Greek and Roman political history, on the one hand, and English political history, on the other, than would the exhaustive biography of all the Greek and Roman and English statesmen that have ever lived, from Lykurgos and Servius Tullius to Gladstone. The study of sociology, in short, is primarily concerned with institutions rather than with individuals. The sociologist does not need to undervalue in any way the efficiency of individual initiative in determining the concrete course of history; but the kind of propositions which he seeks to establish are general propositions, relating to the way in which masses of men act under given conditions.

Here, in conclusion, we may call attention to a broad distinction between the study of sociology and the study of history, which, when duly considered, will throw much light upon the points in Mr. Spencer's doctrine by which Dr. James seems to have been puzzled. The distinction to which I allude is one which may be most fitly illustrated by a reference to the study of geology. The philosophical geologist assumes as data the various physical and chemical properties of the substances of which the earth's surface is composed, and by reasoning from these data, with the aid of all the concrete facts which observation can gather, he constructs his 178 
theory of the actual changes which the earth's surface has undergone, or will undergo, under given conditions. In so far as his knowledge of the physical and chemical properties of matter is exhaustive, and in so far as his judgment is sound, his conclusions with regard to the general course of geological events will be correct. He can even foretell, in outline, what kind of effects will be likely to be produced by a given set of geological causes. But when it comes to predicting, with minute and exhaustive accuracy, the geological future of any particular spot on the earth's surface, he is foiled, through inability to compass all the conditions of the concrete case. And likewise, if he is asked to give the precise physical history of any particular spot on the earth, his conclusions, though sound in principle, may be inadequate, because he may not have gained control of all the special facts required for this individual case. So, although geology is unquestionably a legitimate science, it is nevertheless a science which must deal chiefly with explanations after the fact; it can seldom or never be possible for the geologist to lay down general principles which will be sure to fit every case that may arise.

Just so with sociology. The philosophical student of sociology assumes as data the general and undisputed facts of human nature, and with the aid of all such concrete facts as he can get 


\section{EXCURSIONS OF AN EVOLUTIONIST}

from history he constructs his theory of the general course of social evolution, - of the changes which societies have undergone, or will undergo, under given conditions. If his work has been properly done, he can go so far as to foretell what kind of result is likely to be produced by a given course of political action. But when it comes to predicting the future of any particular society for the next ten years, he is sure to be foiled, through inability to take in the infinitely complex conditions of the concrete case. And in like manner, when he is called upon to interpret the past history of society, he cannot expect to do more than to render explanations after the fact. In order to gain control, moreover, of all the special facts required for the interpretation of each particular case, he must take into account the personal idiosyncrasies of the great men by whom the concrete course of history has been determined. For example, given the political constitution of Rome in the third century before Christ, and the transformation of that constitution into an imperial despotism can be shown to have been an inevitable consequence of the conquest of a large number of surrounding nations by a society so constituted. It was a consequence which not even the practical genius of Cæsar - the greatest, no doubt, that has ever been seen on the earth - could have possibly averted, had all its 


\section{SOCIOLOGY AND HERO-WORSHIP}

unrivalled power been thrown in that direction. But granting that this general course of development was inevitable, the future course of European history was certainly very different, as initiated by Cæsar, from what it would have been if initiated by Sulla or Pompeius. When once this distinction between the standpoint of the sociologist and the standpoint of the historian is thoroughly grasped, one can find no difficulty in comprehending Mr. Spencer's attitude toward the great-man theory. If the purpose of the sociologist were to construct concrete history from an a priori point of view, then he would undoubtedly need to inquire into the mode of genesis of each individual genius, and to take every one of its peculiarities into the account. No such science as this is possible today, and it is not likely that any such science will ever be possible; nothing short of omniscience could compass its problems. As it is, the task of the sociologist is confined to the ascertainment of truths relating to the actions of men in aggregates. It is for the historian to make use of such general truths in interpreting the actions of particular men; and it is the greater extent to which recent historians have been able to employ sociological generalization that is making the historical writing of to-day so much more satisfactory and profound than the historical writing of a generation ago. This in- 


\section{EXCURSIONS OF AN EVOLUTIONIST}

creased use of sociology, this more frequent and conscious reference to the "conditions," the "environment," and all that sort of thing, does not make the modern historian less mindful of the reverence due to great men. On the contrary, it enhances his appreciation of them through his more profound knowledge of the conditions under which they have worked. As an example I may refer to the way in which the life of Cæsar has been treated respectively by Froude and by Mommsen. To both these writers Cæsar is the greatest hero that has ever lived, and both do their best to illustrate his career. Both, too, have done their work well. But Mr. Froude has profited very little by the modern scientific study of social phenomena, and his method is in the main the method of Carlyle. Mommsen, on the other hand, is saturated in every fibre with "science," with " sociology," with the "comparative method," with the "study of institutions." As a result of this difference, we find that Mr. Froude quite fails to do justice to the very greatest part of all Cæsar's work, namely, the reconstructive measures of the last years of his life, which Mommsen has so admirably characterized in his profound chapter on the Old Republic and the New Monarchy. Or, if still more striking proof be needed that the scientific study of the evolution of society is not incompatible with the 


\section{SOCIOLOGY AND HERO-WORSHIP}

highest possible estimate of the value of individual initiative, I may cite the illustrious example of Mr. Freeman. Of all the historians now living, Mr. Freeman is the most thoroughly filled with the scientific spirit, and he has done more than any other to raise the study of history on to a higher level than it has ever before occupied. His writings in great part read like an elaborate commentary on the doctrine of evolution, - a commentary the more valuable, in one sense, in that $\mathrm{Mr}$. Freeman owns no especial allegiance to Mr. Spencer or to any general evolutionary philosophy. Yet this great historian, whose opinions are determined everywhere by the sociological study of institutions, turns out to be at the same time as ardent a hero-worshipper as Carlyle himself, - and vastly more intelligent.

October, 1880. 


\section{VII}

\section{HEROES OF INDUSTRY ${ }^{1}$}

\section{T}

AST of all, in our gallery of heroes, come the heroes of industrial civilization, the bold explorers who have enlarged the area of the civilized world, and the men who by inventive genius have added to the number and complexity of the processes whereby human wants are satisfied. In one sense it was doubtless well to place this group of heroes last; for, while the groups of greatest poets and founders of religions carry us back into an almost mythical antiquity; and while art, philosophy, history, science, and politics have each and all of them their illustrious representatives in ancient as well as in modern times; on the other hand, we find that all the discoverers and inventors who have been thought worthy to be included among the hundred greatest men of history

1 Preface to the eighth volume of The Hundred Greatest Men; Portraits reproduced from Fine and Rare Engravings, London, 1880. 8 vols. 4 to. The eighth volume contains "Inventors and Discoverers."

I reprint this "preface" in this connection, because it affords a good illustration of some of the points in the preceding essay on Sociology and Hero-Worship. 


\section{HEROES OF INDUSTRY}

belong to modern times. Nor is this curious circumstance merely an accident; on the contrary, it affords an apt illustration of one of the most striking and important of all the general aspects of the history of civilization. It is not true that industrial art is later in its beginnings than the arts of warfare and statesmanship, or than the inclination toward scientific inquiry. In their most rudimentary beginnings all these things were, no doubt, nearly simultaneous with each other, as well as with art, religion, and poetry. Pre-glacial men scratched outline pictures of reindeer on their crude stone hammers ; the first man who explained an eclipse as the swallowing of the sun by a dragon, propounded an hypothesis of the kind by which the beginnings of science and of theology are alike characterized; and poetry and music had their humble origin in tales about the dead hero, and rhythmical chants and dances in propitiation of his ghost. And in like manner the ingenious savage of primeval times who first discovered that it was easier and safer to float across a river on a log, if you hollowed out the log, was the legitimate precursor of Fulton and Ericsson. But the names of the clever men who invented canoes and bows and arrows are as utterly unknown to tradition as the names of the earliest myth-makers, or of those pre-Homeric heroes who won for the Aryan people the rich heritage I 85 
of the southern peninsulas of Europe. It was only after civilization had already made considerable progress, after tribes of men had become united into large and stable political aggregates, and after the business of society had acquired a rather high degree of complexity, that individual men could achieve work of any sort on a sufficiently grand scale to arrest the attention of succeeding generations through thousands of years. Granting that some pre-Homeric hero may have had the native powers of a Hannibal, the fact that his achievements did not visibly affect great masses of society, but only the movements of a few petty tribes, would be enough to prevent his fame surviving, save, perhaps, in some vague half-intelligible legends about giants and demi-gods. But after the historical period, in the long career of nascent humanity, had fairly begun - after great societies had been formed, with generals and statesmen, poets and artists, and even philosophers - a long time had still to elapse before anything was heard of inventors of giant calibre and wonderful achievements like Arkwright and Watt. And this fact has in history a marked significance.

Before inventors of this sort were possible, it was necessary, in the first place, that society should have reached a state of comparative stability politically. The ages which witnessed the 186 
exploits of a Belisarius, a Pepin, or a Godfrey de Bouillon, were ages in which neither a Columbus nor a Gutenberg was possible. Amid such chronic political turmail, there was no surplus energy which could be devoted to the exploration and colonization of remote countries, nor was there enough security for industry at home to permit the adoption of new devices for facilitating industrial processes. In the second place, it was necessary both that commercial operations should have begun to cover a wide geographical range, and that the physical sciences should have made considerable progress. The application of both these considerations to the case of a discoverer like Columbus is obvious enough ; but both are equally applicable to the case of such an inventor as Arkwright. Supposing that such a man could have been produced, and could have invented his spinning machine in the age of Augustus or of Trajan, no such results would have followed as were brought about a hundred years ago in England. The general knowledge of machinery was insufficient, and the general extension of commerce was also insufficient. And so it follows, in the third place, that when men of the intellectual calibre of Watt and Arkwright were born in such a state of society as that of ancient Rome, their attention was turned to other things, and not to the mechanical arts; they I 87 
became statesmen or lawyers, poets or philosophers, but not inventors on a grand scale. There was no lack of inventive talent on the part of the ancients, especially as applied to processes of warfare, as was illustrated by the skilful devices with which the Romans, in the first Punic war, wrought such wholesale destruction on the Carthaginian fleets. But the men who devised these remarkable engines, though they effected an important temporary purpose, accomplished nothing toward extending permanently the control of mankind over the forces of nature, or toward modifying the career of industry; and so they are not remembered among the great inventors. The explanation of the non-appearance of Watts and Arkwrights in ancient times is not to be found, therefore, in any assumed lack of inventive talent, but in the social conditions which prevailed in antiquity and down to the close of the Middle Ages.

But there is a still more striking historic significance in the relatively late appearance of the heroes of industry. The paucity of inventors in antiquity, and their increasing frequency in modern times, serves as the index of a great change that has been slowly taking place in the prevailing character of human activity. Whereas the basis of civilization was once mainly military, it has now become mainly industrial. Whereas the occupation of the greater part of mankind was 


\section{HEROES OF INDUSTRY}

once fighting and pillage, it is now the peaceful cultivation of the earth and the transformation of the earth's various productions into endlessly complex instruments for satisfying human wants, both physical and rsthetic. Warfare has long been necessary for the purpose of securing and maintaining the political stability of great masses of men, without which industry itself could not attain to any high development. From this point of view, warfare has not yet ceased to be necessary, especially where civilized societies are molested or threatened by barbarous societies, and no doubt it will be a long time before warfare becomes extinct ; but, in spite of this, the sphere of warfare in modern life has become very much restricted. In such countries as England and the United States, it takes up the time and attention of only a very small part of the community, and only at considerable intervals acts as a real disturbance to the prevailing occupations, which are almost entirely concerned, directly or indirectly, with industry. The enormous complication of modern society, which has been mainly brought about by the labours of industrial discoverers and inventors, in coöperation with scientific inquirers, has brought things to such a pass that men are more and more unwilling to engage in warfare. The disturbance which it works, though slight compared with the chronic misery which it inflicted in earlier times, 


\section{EXCURSIONS OF AN EVOLUTIONIST}

is now beginning to be regarded as unendurable. And along with the diminution of the quantity of warfare, and the restriction of its sphere, there has gone on a gradual alteration in the feelings and in the manners of civilized men. This change has been shown in increased regard for domestic comfort, in the abolition of judicial torture and of cruel modes of punishment, in prison reforms, and generally in increased softness of temper and mildness of manner. That this change is due to the general substitution of industrial for military activity, is too obvious to require detailed argument; yet, when duly considered in all its bearings, the connection of this change with human happiness will be found to be so close that, even had nothing else been accomplished by the inauguration of the industrial era, we should still have ample ground for regarding the great discoverers and inventors as among the chief benefactors of mankind. Though last in order, we can in no wise rank - them as least in noble desert.

November, 1880. 


\section{VIII}

\section{THE CAUSES OF PERSECUTION}

T $\mathrm{N}$ the first series of his admirable essays on contemporary literature, M. Scherer re1 minds us that in I84 I Lacordaire wrote a biography of St. Dominic, in order to prove that he was not the founder of the Inquisition. "Strange are the vicissitudes of opinion," observes the critic. "The Bollandists saw a title of honour where the modern Dominican sees a blemish which he would fain wipe away. While the former scornfully asked what there can be criminal or shameful in delivering heretics to the torture, Lacordaire complains of the calumnies which have injured, in the eyes of posterity, the reputation of the chief of his order." 1 The case is indeed a striking one; but the vicissitudes of opinion which it illustrates are in no way temporary or accidental, but are symptomatic of a general and progressive change in the tempers and opinions of civilized men. The interval of a century or more between the earlier Bollandists and Lacordaire marked a new era in this change of temper, in so far as perse1 Etudes sur la littérature contemporaine, i. 159. 
cution, while losing much of its old cruel intensity, became also discredited and disavowed. It was during this interval that Lessing's theory of the relative truth of opinions, which destroyed the logical basis of persecution, began to make its way among cultivated minds. Though the persecuting spirit has not yet ceased to influence men's actions, it is no longer regarded as a trait to be proud of, but seeks to hide itself under specious disguises. Its manifestations, too, have become correspondingly feeble. The heretic who once would have been racked, thumb-screwed, and burned for writing an obnoxious life of Jesus is now only requested to resign his professorship in the Collège de France, while nobody thinks of such a thing as confiscating the book or cutting off from the author his share of the proceeds of its immense sale. The decline of persecution is in these respects analogous to the simultaneous decline in the warlike spirit. Warfare, once regarded as the only fitting occupation for well-bred men, has come to be regarded not only as an intolerable nuisance, but even as a criminal business, save when justified on the ground of self-defence. And along with this change in the moral estimate of warfare, we observe that whereas the capture of a town not long ago was invariably followed by a carnival of red-handed slaughter and bestial lust, it is now thought unfair to kill 


\section{THE CAUSES OF PERSECUTION}

the pigs or chickens of a non-combatant enemy without at least professing to pay for them. These phenomena are happy symptoms of a general improvement in the way men think and feel ; and they give one some reason for hoping that in due course of time such ugly things as war and persecution will cease to be numbered among the actual difficulties which beset human life.

This general improvement in opinion and temper, when stated with proper limitations as to time and place, is admitted by every one; and it has become an interesting task to analyze it and determine the various circumstances to which it is due. How does it happen that while the representatives of the current orthodoxy would once have roasted you with pious exultation, they are now fain to content themselves with turning you out of an office, and with an apologetic air at that?

This question was incidentally treated by the late Mr. Buckle, in the book which, twenty years ago, was so stimulating to many youthful minds. Mr. Buckle laid it down as one of the cardinal points of his theory of history that civilized men have not improved morally but only intellectually. That on the whole civilized men manage to live in a more peaceable and becoming manner than barbarians, he did not deny; but he thought it necessary for the gen- 


\section{EXCURSIONS OF AN EVOLUTIONIST}

eral purposes of his theory to maintain that this progress has been due entirely to increase in knowledge, and not at all to improvement in ethical feeling. His principal argument in support of this thesis is taken from the history of persecution. He calls attention to the curious circumstance that, in the early struggle between Christianity and Paganism, it was not the infamous Commodus and Elagabalus, but the pure and upright Marcus and Julian who persecuted the new religion. And so, in modern times, many of the extremest bigots have been distinguished for integrity of character and elevation of purpose, - as St. Dominic, Isabella of Castile, Carlo Borromeo, Calvin, and Caraffa. Mr. Buckle accordingly argues that religious persecution has been the product of some of the best impulses of human nature when guided by an erroneous theory of duty. The wretched Commodus cared nothing for religion or for anything else save his sensual pleasures; and so Christian and Pagan were all one to him. But his noble father, Marcus, had the interests of religion uppermost in his heart; and so, in spite of his humane disposition, he felt it necessary to use violent means in putting down such an aggressive heresy as Christianity was then regarded. So, in later times, when persecution was prevalent among Christian sects, the general rule was that those who believed in the 


\section{THE CAUSES OF PERSECUTION}

dogma of exclusive salvation were persecutors, no matter to what sect they belonged. Of this belief, persecution is, no doubt, under any circumstances, the natural outcome. He who believes that his neighbour's heresy is destined to be punished after death by excruciating tortures of infinite duration, will not scruple to use the most violent means for rescuing him from his perilous condition. Obviously, such a conclusion may be entertained without sophistry. Once admit that salvation is possible only within the limits of your own sect, and it may well be argued that you are bound, in benevolence if not in justice, to compel all dissenters to " enter in " to that sect. If persecution be needful to obtain such an object, then, on this view of the case, it would really be hard-hearted to refrain from using it. If pulleys and thumbscrews can substitute eternal happiness for future torments like those described by Dante, then pulleys and thumb-screws are instruments of charity and kindness. On this view of the case, the typical religious persecutor is a man in whom unselfish philanthropy has become such an uncontrollable impulse that, no matter how great the violence to his natural feelings of humanity, he will not hesitate to employ the most rigorous and appalling measures to restrain his fellow-creatures from incurring the risk of endless misery. Such men exist to-day, 


\section{EXCURSIONS OF AN EVOLUTIONIST}

as formerly, mankind having remained substantially unchanged in their moral condition. But they no longer use such rigorous and appalling means of constraining the opinions of their fellow-creatures, because - for one thing they have not the power to do so. And they have lost the power to do so, because such a general scepticism has come to pervade the community that the dogma of exclusive salvation has become discredited. The decline of persecution has therefore - according to $\mathrm{Mr}$. Buckle - been determined solely by intellectual causes, and does not indicate any improvement in the average character or advance in the ethical knowledge of mankind.

In this view there is some truth, but it is so mixed up with error that the total statement is of little worth. That the growth of scepticism, or increasing lack of certainty about transcendental opinions, has had much to do with diminishing religious persecution, is not to be denied. But that the average persecutor is a man whose horrid actions are dictated by an unselfish interest in the welfare of his fellow-men, is a much more questionable proposition. It has not been customary to credit religious bigotry with such lofty motives, - if motives prompting such atrocious actions can at all properly be called lofty, - and we do not find Mr. Buckle disposed to be particularly lenient in his judg- 


\section{THE CAUSES OF PERSECUTION}

ment of individual persecutors, whatever general statements the supposed exigencies of his theory may have led him to make. When he comes to treat of the bigoted Scotch divines of the seventeenth century, he is only too ready to charge them with moral perversity as well as with intellectual ignorance and obtuseness. This is very inconsistent ; but inconsistency can hardly be avoided when one starts with such a singularly half-true theory as that which $\mathrm{Mr}$. Buckle propounded.

Mr. Buckle's fundamental error lay in the attempt to assign distinct parts to elements of human nature that in reality cannot be separated. For didactic or school-room purposes it is well enough to consider separately the intellectual and moral faculties of man. But when we come to examine concretely any actual group of human phenomena, it is hopelessly futile to try to consider intelligence and moral disposition as working separately, or to assign to each its kind and amount of effects. In point of fact they never do work separately, but their combinations are so manifold and intricate that the disentangling of effects becomes impossible. When we look at things rather than words, we see that every complex question of morals is largely also a question of intelligence, and conversely. For example, let us consider what political economists call the "effective desire of ac- 
cumulation." As a rule all men desire to make money, or to increase their general control over the circumstances which make life comfortable or pleasurable; but the effectiveness of this desire is very different with different individuals, and it is immeasurably more effective in the case of civilized men than in the case of barbarians. The savage cannot be made to work to-day in anticipation of wants that are not actually felt at present; but the civilized man will even devote a hundred or a thousand dollars' worth of labour every year to ward off the mere possibility of a loss by fire which is by no means likely to occur. This tendency to provide for future contingencies is at the root of what is called the "effective desire of accumulation," and it furnishes one of the most conspicuous of all the distinctions between civilized men and savages. The progress of mankind in civilization has been to a large extent identical with the growth of this tendency. But, now, how far has this been an intellectual, and how far a moral progress? On the one hand, it may be argued that the ability to labour and to economize to-day in anticipation of future contingencies is an index of self-control or of power to resist momentary temptations; and in so far as this is true, the increase of the " effective desire of accumulation "is an index of the degree to which civilized men have risen morally above the dead level of savagery. But, on 


\section{THE CAUSES OF PERSECUTION}

the other hand, it is undeniable that such a purely intellectual faculty as imagination has a great deal to do with this ability to anticipate future emergencies. A savage does not work to-day in order to keep the wolf from his door next winter, because he cannot frame in his mind an adequate picture of what next winter is going to be. The temptations of to-day he vividly realizes; but of the needs of next winter he can form no mental image distinct or vivid enough to determine his actions. So with the careless, improvident man - who is to that extent a barbarian - in civilized society. No honest man would ever voluntarily run up a bill, to be paid on the uncertain chances of his income six months hence, if he could adequately represent to himself, in imagination, the discomfort or even misery which after six months the bill is liable to produce. I am not speaking now of such pecuniary obligations as are sometimes thrust upon persons by circumstances over which they have no discoverable means of control. I refer only to such obligations as are commonly incurred in civilized society through excess of unproductive expenditure, or what is currently known and stigmatized as " extravagance." The results of extravagant expenditure, especially as connected with the system of " living upon credit," form a very large proportion of the miseries by which modern society is afflicted : 


\section{EXCURSIONS OF AN EVOLUTIONIST}

if all the secrets of society could be laid open for inspection, we should perhaps marvel at the amount of unhappiness which is traceable directly or indirectly to this cause. Yet the reckless assumption of pecuniary obligations does not ordinarily originate in dishonesty of intention. There can be no doubt that it ordinarily originates in mental incapacity to form a distinct and accurate conception of the future results of to-day's actions, coöperating with that comfortable assurance that things will somehow or other come out right, which nearly all men persist in cherishing. The lazy belief that in some unspecified way things will so adjust themselves as to prevent the natural consequences of a wrong or foolish act, is a very common fallacy, upon which George Eliot is especially fond of commenting. This belief, which is responsible for so much imprudence and for so much crime, is itself the product of defects that are partly intellectual and partly moral. It arises partly from a slothfulness of temper which shrinks from the discomfort of dealing with unpleasant facts, and partly from inability to think out complicated relations of cause and effect. Thus deeply and widely inwrought with every phase of the moral power of resisting temptation is that purely intellectual power which we may call " representativeness " - that is, the power of forming distinct and vivid mental pictures of circumstances 


\section{THE CAUSES OF PERSECUTION}

which have not yet begun to exist, or are at any rate remote from us at the present moment. Other things equal, the man who has this power of "representativeness" most fully developed is most likely to exhibit self-control amid the myriad temptations of life. Yet in spite of the highly composite character of the process by which the habit of self-control is reached, the result is a purely ethical result - a result which we estimate solely with reference to its bearing upon the welfare of society. And accordingly, when we praise a man for prudence and selfcontrol, we rightly feel that we are paying tribute rather to his moral character than to his intellectual capacity.

Such being the inextricable complication of intellectual and moral processes, even in such a comparatively simple case as that of "the effective desire of accumulation," we need not expect to be able to deal satisfactorily with such a complex affair as the persecuting spirit without taking into the account both intellectual and moral factors. And in taking both into the account, it must be borne in mind that what we have to say about the one is necessarily incomplete until mentally supplemented by what we have to say about the other.

The diminution in the intensity of the persecuting spirit and the diminution in the atrocity of its manifestations, alike furnish, when duly 


\section{EXCURSIONS OF AN EVOLUTIONIST}

analyzed, an excellent illustration of the intellectual and moral advance of mankind from a state of bestial savagery toward a state of refined civilization. Let us consider first, for a moment, the diminution in the atrociousness of the overt acts by which the persecuting spirit has manifested itself ; and afterward let us proceed more thoroughly into the consideration of the underlying causes of the temper of mind which has led men to persecute one another.

In the lowest stages of human progress which the comparative study of institutions has revealed to us, there are no great political aggregates of men covering large areas of country, supporting themselves by complex and multifarious kinds of industrial activity, and bound together by varied community of interests, guaranteed by laws based on the common consent of all. Viewed in relation to what we now know about the antiquity of the human race, a society like this must be regarded as quite a late and elaborate result of the slow process of civilization. In broad contrast to anything of this sort, we find mankind in their primitive condition such as we may still find it partially exemplified in the institutions of savage races - existing only in little tribes, supporting themselves almost entirely by predatory occupations quite like those by which bears and tigers support themselves, and perpetually fighting with each other for the 


\section{THE CAUSES OF PERSECUTION}

possession of the hunting-grounds that insure their means of subsistence. In this primitive bestial state of society, there is nothing like a normal state of peace. The nearest approach to peace is a state of armed truce. Warfare between tribes goes on chronically, the injury which one inflicts upon another being compensated only by some equivalent injury inflicted in revenge. As all the foreign policy of a given tribe may be thus summed up in perpetual murder of men, so its internal industries may be mainly summed up in the perpetual slaughter of animals that serve for food. Every man is primarily a butcher. To kill something is the prime necessity of life. The direct infliction of death or of physical suffering is the principal daily occupation of all the members of the community ; and, as a correlative effect of all this, the ability to meet death or to endure physical suffering without flinching is one of the attributes of a hero that society prizes most highly. The most complete instance of a society of this sort that has acquired historic fame is that of the Iroquois of $\mathrm{New}$ York, in the seventeenth century. But there is no doubt that, in all the respects we are now considering, our own Aryan ancestors who conquered and settled Europe were substantially like the Iroquois.

Now, in such a state of society as this, it is obvious that men will inflict pain without the 


\section{EXCURSIONS OF AN EVOLUTIONIST}

smallest compunctions and upon very small provocation. The feelings with which we regard to-day the needless infliction of physical suffering would be utterly unintelligible to them. To such men murder and torture are common incidents of life, which no more interrupt the even tenor of their ways than ours are interrupted by railway accidents. A man born in such a state of society expects to meet a violent death, as is shown by our own Norse progenitors, who regarded it as disgraceful to die in one's bed, and an end which a man was willing to encounter himself he might readily be supposed to be willing to inflict upon others. In this way, I think, the excessive cruelty which characterized the persecutions of the Middle Ages is completely explained. When we read of the frightful tortures inflicted upon Arabs, Jews, and Protestants by the Inquisition; when we remember the fiendish outrages perpetrated by the Spanish armies in Holland and by the Imperial armies at Magdeburg; when we recollect that in Spain an auto-de-fe was one of the most imposing ceremonies of the Church, and that, on the marriage of Philip II., burning heretics served as nuptial torches, we are at first inclined to exclaim that such cruelties could never have been. In human nature, as we know it to-day, mean and bad as it too often is, we do not seem to find anything like a parallel to such horrible 


\section{THE CAUSES OF PERSECUTION}

cruelty as this. It has been said that we need but to imagine the state of mind which attributed a similar course of action to Eternal Justice, and conceived it as part and parcel of the essential order of the universe, to render all this explicable. No doubt the self-same ingenuity which men displayed speculatively in theological descriptions of the next world was also displayed practically in such inventions as the rack and the boot, the Virgin armed with knives, or the cell whose walls gradually approached each other and crushed the wretched prisoner into a jelly. It is significant, too, that execution by fire was openly defended as being symbolical of the everlasting punishment destined for the heretic hereafter. At the execution of the lad William Hunter, in I 555, as the fagots were set on fire one of the attendant priests exclaimed, "Behold, as thou burnest here, so shalt thou burn in hell!"

To cite the atrocious theology, however, as the sufficient explanation of the atrocious behaviour, would be, I think, to invert the relations of cause and effect, - in homely phrase, to get the cart before the horse. It was only in a cruel age that the doctrine of hell-fire could have acquired that hold upon men's minds which it had acquired in the Middle Ages. In recent times the doctrine has become almost universally discredited throughout the more en- 


\section{EXCURSIONS OF AN EVOLUTIONIST}

lightened portions of Christendom. Even those who maintain a belief in some kind of endless punishment, no longer insist literally upon the lake of brimstone and the fire that is never quenched. Now, the doctrine of hell-fire has become thus universally discredited, not because it has been scientifically disproved, for science has neither data nor methods whereby to disprove such a doctrine; nor because it has been exegetically shown to be unsupported by Scripture, for the ingenuity of orthodox exegesis has always been equal to the task of making Scripture mean whatever is required; it has been discredited simply because people have become milder in their manners and less used to enduring and inflicting physical pain. The doctrine shocks people's feelings, and so they refuse to believe it, no matter how the logic of the case may stand. The sermons of Theodore Parker on the popular theology well illustrate the change of mood that has come over men's minds with reference to the justice of God : the whole burden of these discourses is the argument that the infliction of endless suffering on the creature is incompatible with infinite justice on the part of the Creator. That such an argument appears sound to-day, whereas it would have seemed absurd to the contemporaries of Luther, is due to the selfsame widening and deepening of human sympathies that have put an end to slavery and to 


\section{THE CAUSES OF PERSECUTION}

judicial torture, that have done away with the horrors of Bedlam and the "stone-hold" of Newgate, and that have embodied in the Constitution of the United States the injunction that "cruel and unusual punishment" must not be inflicted upon criminals.

Now, this general increase in humanity which is discernible throughout the most advanced regions of Christendom during the past three centuries, and which has become especially conspicuous in our own time, is undoubtedly consequent upon the vast increase of industrial at the expense of military activity which has characterized the same period. With the gradual aggregation of men into great and stable communities, and with the accompanying increase in the complexity of social life and in the number of wants which labour is required to satisfy, the sphere of industry has become immensely enlarged and the sphere of warfare has become correspondingly restricted. I do not forget that great and terrible wars still occur, but it remains none the less true that fighting has ceased to be recognized as the principal, or even as a very considerable, part of the business of society. Private warfare, once universal and incessant throughout western Europe, has become extinct, and in the Northern States of the American Union it has never existed. Brigandage survives only in out of the way corners of the 


\section{EXCURSIONS OF AN EVOLUTIONIST}

most backward countries of Christendom, such as Spain and Sicily, or else in localities where civilization comes into geographical contact with barbarism, as in Thessaly and Albania, or on the extreme western frontiers of our own country. Duelling has become nearly obsolete, and is dealt with as a crime, while the so-called code of honour upon which it thrived has become an object of general derision. The sword is no longer a part of a gentleman's wardrobe, and laws are framed to prevent the carrying of daggers and pistols. Only soldiers on parade and sportsmen nowadays carry deadly weapons openly. While the sportsmanship, moreover, which simply inflicts death on bird or beast is still held in esteem, emphatic protests are made against the sportsmanship which wantonly inflicts pain, as we have seen in the controversy about fox-hunting between Mr. Freeman and Mr. Trollope. Organized societies exist for the protection of domestic animals against cruel treatment. Even where it is necessary to inflict pain for the purpose of preserving life, as in the profession of the surgeon, we do all in our power, by the use of anæsthetics, to reduce the pain to a minimum. And even where it is necessary to inflict death as a means of protection to life, as in the execution of murderers, the dreadful work is done as gently as possible, and is kept hidden from the gaze of the public. 


\section{THE CAUSES OF PERSECUTION}

It has thus come to pass that, in such communities as England and our own Northern States, the majority of individuals may live all their lives without ever being called upon to take part in putting a fellow-creature to death. Most of us, I presume, have never witnessed a violent death, and know of such things only by hearsay - only by reading the newspapers and books of history. The consequence is that a kind of feminine softness has come over our tempers - a tenderness which shrinks from the very thought of death and suffering purposely inflicted as intolerable. In military ages any approach to such softness of temper was stigmatized as unmanly, and such a type of character could not flourish, because it was unsuited to the conditions of life in a perpetually belligerent community; but in our own industrial age this mild type of character is fostered by all the potency of public approval. But it is not only by restricting the sphere of warfare that our complex industrial civilization has nourished a temper that shrinks from the infliction of pain. Productive activity has operated in this way directly, as well as indirectly through restraining destructive activity. Social life has lost the half-brutal, half-ascetic aspect befitting ages when life was for high and low little more than a struggle for existence. It is a trite remark that the American labourer to-day possesses many physical comforts which a medi- 


\section{EXCURSIONS OF AN EVOLUTIONIST}

æval king was unable to secure. Throughout the greater part of civilized society, the struggle nowadays is not for the bare means of subsistence, but for the attainment of a certain amount of elegance and luxury. The contrast is great between the mediæval baron who, in time of peace, had no resources but in hunting or in tournaments, or in getting drunk, and the modern citizen with his theatre and opera, his lectures and concerts, his novels and magazines lying on the table, his household pictures and bric-à-brac, his hours of work at his office or in the stock-exchange, relieved by the quiet domestic enjoyment of the evening. Accustomed to all this complicated comfort, our growing tendency to shrink from needlessly encountering with what is disagreeable is still further enhanced, and this tendency produces a visible effect upon our manners. Whatever savours of personal contention, whatever is liable to wound the feelings or disgust the senses, is peremptorily proscribed in the usages of polite society. Compared with English and American gentlemen of to-day, the gentlemen of Shakespeare's plays often talked like boors or ruffians.

The diminution in the atrociousness of persecution, then, is simply one among a hundred illustrations of the change in men's tempers that has been wrought by the change in men's occupations which has characterized the growtb 


\section{THE CAUSES OF PERSECUTION}

of modern society. From being predominantly warlike and predatory, human activity has come to be predominantly pacific and industrial, and out of this change have grown our milder beliefs as well as our milder manners.

We have not yet, however, got to the bottom of the matter. We have accounted for the decrease in the cruelty with which the persecuting spirit has manifested itself, but we have now to consider the underlying causes of the temper of mind which has led men to persecute one another; we have to show, in particular, how it is that, so far as all matters of religious belief are concerned, the persecuting spirit has already greatly diminished in intensity, and will no doubt eventually become extinct among civilized men. We shall find that the change is deeply inwrought with the progress of mankind, both morally and intellectually.

The persecuting spirit has its origin morally in the disposition of man to domineer over his fellow-creatures, intellectually in the assumption that one's own opinions are infallibly correct. We know very well how children are apt to behave when arguing some question of no great consequence. Their little passions warming with the discussion, they pass from argument to abuse, they call each other hard names, and, at last, they begin to pound each other. Most people, I imagine, must have had experiences of 


\section{EXCURSIONS OF AN EVOLUTIONIST}

this sort in their childhood. I recollect, when quite a little boy, coming to blows with a schoolmate over the question whether Napoleon really won the battle of Eylau. Now the spirit which prompts a child to pound his companion who resists him in argument is identical with the spirit which prompts a man to calumniate, torture, burn, or otherwise put down and injure his neighbour who refuses to reverence the things which he himself deems sacred. The more we reflect upon it the more we shall be convinced that at bottom the feeling is the same in the two cases, though in the latter it is accompanied and disguised by other feelings. Now, what is this feeling but the disposition to domineer, to assert one's own personality at the expense of neighbouring personalities, - a disposition eminently characteristic of the brute and of the savage, but less and less characteristic of man as he becomes more and more civilized? Bearing this in mind, and remembering the fable of the wolf and the lamb - remembering that a strong passion is never at a loss for reasons, and that no one is more thoroughly the dupe of the false reasons than the man himself who is under the control of the strong passion - remembering this, one has the key to a large part of the history of persecution. The paradox, as regards the "benevolent persecutors," is a paradox no longer. It becomes explicable how 


\section{THE CAUSES OF PERSECUTION}

a man may sincerely believe himself to be doing God service, while he is in reality obeying an impulse which, in an ultimate analysis, is neither more nor less than the impulse to domineer over one's fellow-creatures. Thus, though the plea of mistaken benevolence may now and then be properly urged in extenuation of certain special acts of persecution, it cannot excuse persecution, or obscure the fact that its diminution is largely due to a slow moral progress, - to a decrease in self-assertion, and a concomitant increase in respect for the rights of other people.

Very closely connected with this moral root of the persecuting spirit in mere arrogant selfassertion is its intellectual root, in the assumption that one's own opinions are infallible. That persecution can have no theoretical basis or justification, save on the assumption that somebody's opinions are infallibly true, has been so thoroughly illustrated by Mr. Mill in his beautiful essay on "Liberty," that I need not dwell here upon this part of the subject. It behooves us, however, to consider in what ways the progress of civilization has contributed to weaken the spirit of self-assertion and the assumption of infallibility.

Obviously, the disposition to domineer over others, to assert one's own personality at the expense of others, is simply one particular phase 
of the disposition to kill one's enemies which characterizes human society in its primeval stages of development. It is a temper of mind which was favoured by the general condition of things when there were no political aggregates larger than simple tribes which were chronically at war with one another. What I have said above, in considering the effects upon the atrocity of persecution of the substitution of a normal state of peace for a normal state of warfare, will also apply to the present case. The disposition to domineer over your fellow-man - to make him obey you or assent to your opinions, whether he will or no - is only an evanescent phase of the disposition to kill him if he interferes in any way with the accomplishment of your purposes in life. The very same diminution in the sphere of military activity, attendant upon the aggregation of men into great and complex political societies, which we found to explain the decreasing atrocity of persecution, explains also the decreasing vitality of its moral foundation in the disposition to domineer over one's fellow-men.

The weakening of the assumption of infallibility in one's own opinions is manifestly a consequence of the same set of coopperating causes. When one's life is extremely simple and monotonous, consisting of very few experiences that are perpetually repeated; when one 


\section{THE CAUSES OF PERSECUTION}

is not often compelled to test the validity of one's own conclusions by comparing them with the different conclusions which other people draw from the same data; when one lives amid a certain group of beliefs, customs, and observances that are never brought into comparison (save, perhaps, in exterminating warfare) with other differing groups;-under such conditions as these it is noticeable that one's opinions are formed with great promptness, and when once formed are unchangeable. These are the conditions under which the opinions of savages are formed, and the chief characteristic in the opinions of savages is their wonderful rigidity ; you can no more change them than you could teach a fox, when chased by the hunter, to climb a tree like a cat. Or, consider the case of an ignorant woman, in the lower classes of civilized society. Her opinions about men and things are formed in an instant, by some mental process of which she can render no account, and when once formed are utterly impervious to fact or to argument. She acts on the tacit assumption that she is infallible, precisely as the savage acts. To think of hesitating for a moment and questioning the validity of their opinions, is something which never happens to either of them.

This is the obstinate fashion in which men used to cling to their opinions in that crude state 


\section{EXCURSIONS OF AN EVOLUTIONIST}

of social development in which each little society was at war with every other, and in which, accordingly, it was impossible to bring a given set of opinions into free contact with another set, within the limits of one and the same society. As men have gradually been brought together into great and complex societies, as their opinions have been brought more and more into the focus of a common point of comparison, this rigidity of the mental processes - so like the rigidity of the mental processes of the lower animals - has gradually yielded to circumstances such as favour flexibility. With the case of the savage or the woman who comes to scrub the floor, contrast the case of the scientific philosopher, whose opinions are slowly formed after a long and careful weighing of conflicting evidences, and when once formed are held subject to perpetual revision and modification. On considering these two contrasted cases, it becomes obvious how the aggregation of men into great and complex societies, bringing with it increased variety of experience and increased knowledge of the manifold liability to error, has operated to destroy the confident assumption of infallibility which characterizes the bigot and the savage.

We have now made out, I think, a very fair explanation of the way in which the persecuting spirit has been affected by the general progress 


\section{THE CAUSES OF PERSECUTION}

of human society. But one of the deepest considerations of all still remains to be treated.

In the early stages of society, as illustrated by such writers as Sir Henry Maine, the unit of society is not the individual, but the family or clan. In a tribe of primitive savages there is no such thing as individual rights or individual obligations, in the modern sense. It is the clan as a whole that incurs obligations and asserts its rights as far as it is concerned with adjacent clans. Amid the pressing interests of the tribe, in the fierce struggle for existence, the individual has no chance whatever for especial consideration. The traces of this state of things confront us continually as we study ancient history, where no fact is more conspicuous than the utterly ruthless way in which the individual is sacrificed to the state. The bearing of this state of things upon the history of persecution goes farther than anything else toward explaining that dreadful history. In the early stages of society, when only small political aggregates have been formed, and when each little aggregate is perpetually struggling for its life with adjacent aggregates, the only kind of responsibility known to the tribe is corporate responsibility. The tribe, as a whole, is held to be responsible corporately for the acts of each of its members, and hence it is necessary that the acts and beliefs of every one of the members 


\section{EXCURSIONS OF AN EVOLUTIONIST}

should be subject to the approval of the tribe. If any one individual does something that is displeasing to the gods, the whole tribe is liable to be punished for the misdeed of this one person. This feeling was universal in ancient society, and, until we realize how intense it was, we shall be unable to understand some of the most remarkable scenes of ancient history. Take, for example, the frantic excitement which was stirred up in Athens, just before the expedition against Syracuse, by the mutilation of the rude wayside statues of Hermes. It is impossible for a modern man to understand this furious excitement unless he duly considers the fact that, in the minds of the Athenians, the whole community - and not merely the individual criminals concerned - was responsible to the gods for this outrage. The whole community might be visited by the angry gods with famine and plague because of the misdeeds of a few of its graceless members.

This intense feeling of corporate responsibility pervades all the life of ancient society, and by keeping it in mind we shall understand many occurrences which without this key we should find incomprehensible. When we bethink ourselves how far such deeply rooted feelings propagate themselves in history, we shall be inclined, I think, to find in this sense of corporate responsibility the weightiest cause 


\section{THE CAUSES OF PERSECUTION}

of those deeds of persecution which have made history hideous. To remove the heretic, lest God curse us all for his sake, - this no doubt has been the feeling that, more than any other, has justified the use of racks and thumb-screws.

But with the progress of society toward wider and wider political aggregation, and toward greater and greater political stability, - along with the growing complexity of industrial pro:esses, and along with the partial elimination of warfare, - there has slowly grown up a feeling that it is the individual, and not the tribe or the society, that is ultimately responsible for the individual's opinions on matters of religion. Whatever we may think to-day about the results or the method of Mr. Robert Ingersoll, we certainly do not entertain the dread that because of Mr. Ingersoll's crude opinions, or his intrusive manner of expressing them, we are in danger of a famine, a plague, or a civil war next year. The aggregation of small communities into great nations, and the growing complexity of the industrial processes by which great nations are sustained, have entirely obliterated in our minds the recollection of the kinds of belief and the kinds of moral obligation which characterized the primitive tribal communities. The phase of feeling characteristic of the primitive community showed itself all through the Middle Ages. In the following paper I shall show how 


\section{EXCURSIONS OF AN EVOLUTIONIST}

the beginnings of modern history were signalized by the revolt of Luther against the doctrine of corporate responsibility for opinion, and against the assumption of infallibility on the part of a special body of men.

November, 1880. 


\section{IX}

\section{THE ORIGINS OF PROTESTANISM}

T N the year 1609 one of the most atrocious crimes of which history preserves the record

1 was perpetrated by the Spanish government. The Moriscoes, or Christianized descendants of the conquered Moors, had long been objects of suspicion and hatred to the Spaniards, and especially to the Spanish clergy. During the sixteenth century they had been so cruelly treated that in 1568 they had risen in rebellion among the mountains of Granada, and it had taken three years of obstinate fighting to bring them to terms. Their defeat was so crushing that it was no longer possible to regard them as politically dangerous, but their orthodoxy was strongly suspected, inasmuch as the grandparents of the present generation had been converted to Christianity only by brute force. In 1602 the Archbishop of Valencia proposed that all the Moriscoes in the kingdom, with the exception of children under seven years of age, should be forthwith driven into exile, that the nation might no longer be polluted by the slightest suspicion of unbelief. The Archbishop of Toledo, pri- 


\section{EXCURSIONS OF AN EVOLUTIONIST}

mate of Spain, heartily agreed with his reverend brother, save as far as concerned the little children, whom he thought should be included in the general banishment. To Bleda, the famous Dominican, even these measures seemed insufficient, and he argued that all the Moriscoes in Spain - men, women, and children even to the new-born babe - should be ruthlessly murdered, " because it was impossible to tell which of them were Christians at heart, and it was enough to leave the matter to God, who knew his own, and who would reward in the next world those who were really Catholics." The views of the Archbishop of Toledo finally prevailed, and in I609, as Mr. Buckle puts it, " about one million of the most industrious inhabitants of Spain were hunted out like beasts, because the sincerity of their religious opinions was doubtful." Their deportation to Morocco was attended by characteristic barbarities. The number of those massacred on the way seems to have exceeded the number of the victims of St. Bartholomew; while of those who reached Africa, thousands were enslaved by Mohammedan Moors, or slain by robbers, or starved in the desert.

Now these Moriscoes, thus driven from the land by ecclesiastical bigotry, were the most skilful labourers Spain possessed. By their expulsion the manufacture of silk and paper was 


\section{THE ORIGINS OF PROTESTANTISM}

destroyed, the cultivation of sugar, rice, and cotton came to an end, the wool-trade stopped, and irrigation of the soil was discontinued. The disturbance of industry and the consequent distress were so great and so far-reaching that by the end of the seventeenth century the population of Madrid had decreased by one half, and that of Seville by three quarters; whole villages were deserted, large portions of the arable land went out of cultivation, and brigandage gained a foothold which it has ever since kept. In short, the economic ruin of Spain may be said to date from the expulsion of the Moriscoes : after nearly three hundred years the country has not yet recovered from the disastrous effects of that unparalleled crime and blunder.

Yet this atrocious deed was done with the unanimous approval of the Spanish people. Even the gentle-hearted and high-minded Cervantes applauded it, while Davila characterized it as the most glorious event in all Spanish history. Nay, even in recent times, the eminent historian Lafuente, while recognizing the terrible economic results of the measure, maintains that it was nevertheless productive of immense benefit by securing the "religious unity" of the whole people. Here we have the true Spanish idea - or, to speak more accurately, the true ecclesiastical idea, which, through an unfortunate combination of circumstances, has al- 


\section{EXCURSIONS OF AN EVOLUTIONIST}

ways dominated the Spaniards more completely than any other European people, but which has wrought mischief enough in other countries than Spain. To insure absolute "religious unity," to insure that from the Pyrenees to Gibraltar all people should think exactly alike about questions which are confessedly unfathomable by the human mind, - this seemed to the Spaniard an end of such supreme importance as to justify the destruction of two hundred thousand lives, and the overthrow of some of the chief industries of the kingdom. The annals of persecution in other countries serve but to point the same moral. Measured by the quantity of suffering it has entailed, as well as by the wholesale disregard of moral rectitude it has involved, the history of the attempt to enforce " religious unity" is, no doubt, the blackest of all the black chapters in the awful career of mankind upon the earth.

Yet, no doubt, the object for which all this agony has been inflicted, and all this villainy perpetrated, is an utterly worthless object, when considered with reference to the conditions of life in a civilized society. Not only is it not desirable that all the members of the community should hold the same opinions about religious matters, but it is far better that they should not all hold the same opinions. To the Frenchman's sneer about the English, who have twenty 


\section{THE ORIGINS OF PROTESTANTISM}

religions and only one sauce, I should answer: By all means let us have twenty religions, even if we can have but one sauce. In comparison with the inscrutable realities which religion postulates, our most elaborate attempts at theology are so feeble that it is not likely that any given set of opinions can represent more than the tiniest segment of the truth:

"Our little systems have their day ;

They have their day and cease to be ;

They are but broken lights of Thee, And Thou, O Lord, art more than they."

In view of this weakness of reason, when confronted with the mighty problems of religion, it behooves each one of us to greet his neighbour's opinions as, perhaps, containing a glimpse of truth which his own have lacked; not to scoff or frown at them as "different" from his own. If "religious unity" is ever to have any value, it can only be when it is reached as the outcome of the free untrammelled working of countless individual minds. Until it is reached in this way, "religious unity" can mean nothing but " intellectual torpidity where religious questions are concerned;" and, meanwhile, diversity of opinion is the best guarantee we can have that a healthy intellectual activity is going on.

In the present paper, however, I propose to examine the desire to enforce "religious unity" by the light of the comparative method; let us 


\section{EXCURSIONS OF AN EVOLUTIONIST}

see if there has not existed a state of society in which it may have been desirable that all the members of the community should think alike, on religious as well as on other subjects.

Toward the close of my paper on "The Causes of Persecution," I called attention to the intense feeling of corporate responsibility which pervaded all the life of ancient society, and which, no doubt, goes farther than anything else toward explaining the genesis of persecution. To understand the origin and meaning of this notion of corporate responsibility, we must carry our thoughts back to that primitive state of society when there are no political aggregates more extensive than the clan, or, at any rate, than the tribe, formed by the coalescence of kindred clans. In this lowest stage of human progress, blood-relationship furnishes the only possible bond by which any concert of action among men can be secured. The ideas of right and duty, in so far as recognized at all by the dim intelligence of nascent humanity, are recognized only within the limits of ascertainable blood-relationship. The comparative study of institutions, among civilized people and among savages, has established beyond doubt that this was the social condition of mankind at the beginning of its distinctively human career. I have myself shown that the very same cooperating processes which originated the family, 226 


\section{THE ORIGINS OF PROTESTANTISM}

originated, also, those intellectual and moral differences by which humanity was first raised above the common level of apehood. ${ }^{1}$ Had the infancy of man been completed within a period of three or four months, as is the case with other mammals, man would never have become human : there would have been no social aggregation, and there could not have been originated that long-enduring process of intellectual and moral development which was rendered possible only through social aggregation, and which went on so far during prehistoric times as to raise the human brain to nearly twice the dimensions of the brain of the highest ape. But the prolonging of the period of helpless infancy brought with it the genesis of the family, and thus inaugurated the first enduring principle of concerted action among human beings.

By simple expansion, the family grew into the clan, and by expansion and coalescence small groups of clans grew into the tribe; and throughout these earliest stages of social organization the principle of concerted action remains the same that was first inaugurated by the genesis of the family. In the tribal stage the ideas of right and wrong are recognized, but their application is strictly determined by the necessities of the tribe. Right actions are those which help,

1 See below, the paper on the "Meaning of Infancy." See also Darwinism and other Essays, iii. 
or are supposed to help, the tribe in its perpetual struggle for existence with surrounding tribes; wrong actions are those which hurt, or are supposed to hurt, the tribe's chances of success. It is wrong to murder a fellow-tribesman, though human sacrifices or female infanticide may be sanctioned from motives of general policy ; it is praiseworthy to murder a stranger, unless perhaps when he belongs to some powerful tribe which it is imprudent to offend. Above all things, the prime social and political necessity is social cohesion within the tribal limits, for unless such social cohesion be maintained, the very existence of the tribe is likely to be extinguished in bloodshed. Such was doubtless in general the state of things which lasted for more than four thousand centuries, during which men lived and died upon the earth before they had acquired enough intelligence or enough political stability to leave anywhere a written record of their thoughts and deeds. Ten or twelve thousand generations of ruthless military discipline! ten or twelve thousand generations of rigorous conformity to tribal requirements, enforced under the perpetual threat of tribal extinction! Such was the terrible schooling that was needed to fit men for aggregation into great and complex societies. Included in this military discipline, as part and parcel of it, was an incipient ecclesiastical discipline. Long before the 228 


\section{THE ORIGINS OF PROTESTANTISM}

dawn of history, ancestor-worship had begun. The ghosts of dead chieftains, in this primitive philosophy, survived as the tutelar deities of the tribe, ready now, as of old in their life-time, to punish misdemeanours, but clothed with a power all the more vast and awful, as its nature and limits were but vaguely and incoherently imagined. To offend in any particular against the ethical and ceremonial code established from time immemorial under the pressure of tribal necessities would be to invite the vengeance of the tutelar deities. The offender must be curtailed of his liberty, or maimed, or killed, or else by an easy inference the fellow-tribesmen would be liable to be held as participators in the offence, and dire calamity might thus befall the whole tribe. Tempest or famine or pestilence or defeat in battle might be expected by the tribe which should fail to punish an offence on the part of one of its members against the tutelar deities. This feeling of corporate responsibility is always to be found among tribally organized barbarians; it existed among our own barbaric ancestors; examples of it are numerous in Græco-Roman antiquity; and there can be no doubt that in primitive society the feeling was universally prevalent and ferociously intense withal, since no other human passion is so cruel as fear, and no other kind of fear is so cruel as the vague dread of the supernatural. And obvi- 
ously there is no kind of conduct which would so surely awaken the dread of supernatural vengeance as any neglect of the time-honoured rites due to the tutelar deities, or any expression of opinion, whether serious or flippant, which might be interpreted as derogatory to their awful dignity.

The feeling of corporate responsibility, therefore, grew out of the necessities of that primeval society in which the highest known order of political organization was the tribe, and in which neighbouring tribes were perpetually at war with each other. Under such circumstances, those tribes in which the feeling of corporate responsibility was most intense must in general have shown the highest capacity for coherent organization, and must have subjugated or extinguished those tribes in which the feeling was more feebly developed. The feeling must have grown by natural selection until it became, as it were, part and parcel of the mental constitution of mankind. No wonder that we find the feeling so strongly developed among the highly cultured Greeks and Romans and Jews. A feeling so deeply rooted in men's ancestral experiences must needs survive long after the establishment of social conditions totally different from the conditions which implanted it. If we wish for evidence that this sense of corporate responsibility has lain at the bottom of a great part of 


\section{THE ORIGINS OF PROTESTANTISM}

the persecution which has made ecclesiastical history so abominable, we may find it, ready to hand, in the tale of wickedness with which I began the present discussion. One of the arguments for the banishment of the Moriscoes, upon which the Archbishop of Valencia mainly relied, was the argument that the whole Spanish people were in the sight of Heaven responsible for the doubtful orthodoxy of these converts from Islam. "He declared that the Armada, which Philip II. sent against England in 1588, had been destroyed because God would not allow even that pious enterprise to succeed while those who undertook it left heretics undisturbed at home. For the same reason, the late expedition to Algiers had failed; it being evidently the will of Heaven that nothing should prosper while Spain was inhabited by apostates." 1 This argument, which produced a powerful effect upon both king and people, was conceived precisely in the spirit of the primeval savage. And so when Mary Tudor, being afflicted with dropsy, supposed that she was about to give birth to a prince who should exclude from the succession the heretical Elizabeth, when the $T e$ Deum was sung in St. Paul's, and vessels on the Thames fired salutes, and merry bells were set ringing in all the churches, and still the expected prince did not make his appearance; when, after

1 Buckle, vol. ii. p. 47. 


\section{EXCURSIONS OF AN EVOLUTIONIST}

the keen disappointment, the queen began to reason with herself, "she could not doubt that her hopes had been at one time well founded; but for some fault, some error in herself, God had delayed the fulfilment of His promise. And what could that crime be? The accursed thing was still in the realm. She had been raised up, like the judges in Israel, for the extermination of God's enemies; and she had smitten but a few here and there, when, like the evil spirits, their name was legion." 1 As the practical result of these pious meditations, some fifty Protestants - one of my own ancestors among them - were forthwith burned at the stake. Obviously, Mary's reasoning, like that of the Spanish Archbishop, had no validity or significance whatever, except as it appealed to that terrible sense of corporate responsibility which they had inherited as a tradition from prehistoric times.

Now, although the feeling of corporate responsibility for opinions was still so powerful as recently as the sixteenth and seventeenth centuries, although plentiful traces of it may still be found at the present day, nevertheless the state of things by which the feeling was logically justified has long since passed away. And it has passed away, no doubt, never to return. It began to pass away so soon as men began to become

1 Froude, History of England, vi. 330. 


\section{THE ORIGINS OF PROTESTANTISM}

organized into great nations, covering a vast extent of territory, and secured by their concentrated military strength against the gravest dangers of barbaric attack. In European history, the first conspicuous approach to this new state of things was made by the tremendous conquests of Rome. For a period of five centuries after the overthrow of Carthage and Macedonia, the Roman government held together a greater number of men of different races, tongues, and faiths than had ever before been so long held together since the world began; and, throughout the vast territory over which it held sway, it succeeded in maintaining a state of peace which, imperfect and fitful as it seems from the point of view which we moderns have reached, still presented a striking contrast to the perpetual and universal warfare of primitive peoples. Under this condition of things, the old ideas and feelings began to be modified in many ways. The passage from ancient to modern ideas of social obligation can be largely traced in the wonderfully suggestive history of the Roman jurisprudence. In the early ages of the Republic we find the legal existence of the individual well-nigh merged in that of his family, and we find his duties and obligations defined entirely by the status in which he is born. But, by the time of the great codification which went on under the Empire we find the legal existence 


\section{EXCURSIONS OF AN EVOLUTIONIST}

of the individual distinctly acknowledged, and his duties and obligations largely determined by contract, as is the case in modern society. Manifestly, the relations sustained by the individual toward so great a whole as the Empire could not be like the relations sustained by the individual toward so small a whole as the tribe. Through the sheer breaking up of tribal ideas of obligation which the Empire everywhere effected, the ideas of individual obligation characteristic of modern society began to emerge into the foreground. The most fundamental and far-reaching effect of Roman conquest was the decomposition of primitive ideas, political and social, legal and religious. The world of separate tribes and separate cities, each with its peculiar laws, and each with its local deities and rites, came to an end, and was replaced by an organized European world, with its Roman law, based on ethical principles acknowledged by vast masses of men, and with its Christian religion, based on the assertion of the universal brotherhood of men and the universal fatherhood of God.

As in the Roman law, so also in Christianity, the innumerable new relations into which men were thrown resulted in a great deal of abstraction and generalization concerning the scope of men's rights and duties. In the one case as in the other, the liberation of the individual from 


\section{THE ORIGINS OF PROTESTANTISM}

the old tribal bonds was effected by the process which brought him into immediate relations with a state possessing a dominion that was practically universal, and with Deity regarded as eternally ruling the whole created world. The individual salvation of each human being, as dependent upon his spiritual attitude toward his heavenly Father, is an idea distinctly present in Christianity as first enunciated, and in the prominence assumed by this grand idea the old notion of tribal allegiance to a tutelar deity fades entirely out of sight. The idea that salvation is to be attained through conformity to a certain prescribed set of opinions or of ritual observances, or through obedience to a certain ordained priesthood, finds no support whatever in the teachings of Jesus as reported in the Gospels. So far from lending support to this primitive idea of religious obligation, Gospel Christianity is in itself a most emphatic protest against it; and it was through this wholesale discarding of primitive ideas that Christianity secured from the outset an element of permanence such as no other scheme of religion has ever possessed. Miraculous legend, impressive ceremonial, priestly devotion, doctrines awful or consoling, - these things have at times been potent influences in maintaining the sway of Christianity over the human mind ; but the potency of such influences as these is limited in extent and in duration, - it is dependent 


\section{EXCURSIONS OF AN EVOLUTIONIST}

upon transient states of society and transient phases of opinion. The permanent element in Christianity - the feature whereby it may still claim the allegiance of modern thinkers who reject the supernatural theology and the symbolic ritual - is the fact of its placing the conditions of salvation, not in doctrine or in ceremonial, but in right conduct as flowing from the impulse toward a higher life in which religion most essentially consists. Not they that say unto me, "Lord, Lord," but they that do the will of our Father in heaven, - such was the first authoritative definition of the aspect of human life with which Christianity primarily concerns itself.

Thus, Christianity in its earliest form may be regarded as a kind of Protestantism, in which old heathen ideas of conformity to tribal requirements as to doctrine and ritual were utterly discarded, and in which religion was presented as something which concerns the individual alone in the presence of the infinite God. But so lofty a conception as this could not be realized so long as Christianity had to make its way as a militant force among peoples who were still largely under the influence of primeval ideas of corporate responsibility for opinion. Already, in their struggle with the pagan society of the Empire, the preachers of the new ideas found it necessary to become organized as a "church militant," and to have certain recognized dogmas, or - to use 


\section{THE ORIGINS OF PROTESTANTISM}

the old and expressive term - symbols, as a sort of banner around which to rally their adherents. This militant character of the early church explains the persistency with which all gnostic or rationalizing interpretations of sacred mysteries were condemned and set aside; they were liable to the charge of offering some possible ground of compromise with pagan philosophic ideas. The most rigid and uncompromising symbol the one which involved the most complete selfsurrender to the interests of the common struggle - was the one which worked the best; and hence there lay a certain sort of rude practical logic beneath the much-derided and often misquoted phrase of Tertullian, Credo quia impossibile. ${ }^{1}$ To rationalize the new dogma of the Trinity was in itself to make a quasi-concession to the Neo-Platonists; and herein was reason enough why the Athanasian interpretation should supplant the Arian. An organized priesthood was necessary, too, in order to preserve the liberty of the Church at a time when the political structure of society was such that there was no other available check upon the autocratic power of the emperors. In its attitude as a "church militant," therefore, Christianity was compelled to enforce conformity to dogma, and

1 This point is well brought out in the Rev. J. H. Allen's excellent little book, Christian History in its Three Great Periods. 


\section{EXCURSIONS OF AN EVOLUTIONIST}

obedience to priestly authority; and in doing these things, the feeling, still rife among men, to which it appealed, was the old feeling of corporate responsibility for opinion.

The old feeling, thus strongly appealed to at a time when its basis in the conditions of primeval society had been destroyed, received still stronger reinforcement when the Church took upon itself the tremendous task - to which the political forces of the Empire were no longer competent - of civilizing the barbaric world. From the time of Ulfilas to the time of Anschar there were five centuries of militancy, during which all the power of the spiritual as well as of the secular arm was taxed to the utmost in the work of making the Teutonic barbarians adopt the results of Græco-Roman civilization. In warfare of this sort, the Church could do nothing less than appeal to the only available religious conceptions with which the past experience of its converts had made them familiar. As in the political system of these ages of transition between ancient and modern civilization we observe a partial and temporary retrogression toward a pre-Roman tribal and local polity, - as exemplified in some of the aspects of feudalism, - so too in religious conceptions we may observe a partial and temporary renascence of primitive pagan ideas. To say that the Church adopted many pagan symbols is only to say that 


\section{THE ORIGINS OF PROTESTANTISM}

the great men who shaped its missionary policy talked to their pagan converts in the language which they were best capable of understanding. The Church thus adopted the doctrine of corporate responsibility for opinion, very much as it adopted Yule-tide and Easter feasts, and the worship, under a scriptural name, of the Berecynthian Mother. The outcome of all this was that in the process of Christianizing the pagan world Christianity itself became more or less deeply paganized. Hence those terrible persecutions, of Albigensian and other heretics, which marked the epoch of the Church's greatest supremacy, and which no one thought of justifying from the teachings of Jesus, but only from Old Testament texts expressing the crude primitive notions of the Jews in their semi-barbarous period.

But now, after the Teutonic and Slavic barbarians had become pretty nearly all converted; after Europe had come to feel itself reasonably secure against being overrun by Saracens or Mongols; after the principal European kingdoms had arrived at something like political stability; after the Crusades had shaken up men's ideas by bringing the civilizations of the East and West in contact with each other; and after the partly paganized Church had begun to put forth such pretensions as, if successful, would have converted Europe into a caliphate, an- 


\section{EXCURSIONS OF AN EVOLUTIONIST}

would thus have inflicted upon it the doom of stagnation like that which has overtaken the Mohammedan world; after this state of things had been reached, in the course of the thirteenth century, then symptoms of dissent began to manifest themselves, - vague murmurs, which heralded the great Protestant storm that was gathering. It was in the thirteenth century that the Church thought it necessary to desecrate the noble enthusiasm which had inspired the Crusades, by employing it to crush out heresy with fire and sword in the southern parts of France, - thus beginning that detestable scheme of robbing the French nation of its nimblest minds and strongest characters, which was continued in scenes like the St. Bartholomew, and was consummated in the infamous dragonnades of 1685. It was in the thirteenth century, too, that the Spanish mind hit upon that ingenious device of the Inquisition, whereby all speculative originality was to be effectually extinguished in so-called " acts-of-faith," to the proper performance of which an abundant supply of fire-wood was the principal requisite. These new developments of the persecuting spirit show how formidable the spirit of dissent was then becoming. This spirit of dissent, both at that time and in later days, was fond of assuming the form of a protest against the pagan corruptions of the Church, and in behalf of a return to the sim- 


\section{THE ORIGINS OF PROTESTANTISM}

plicity of organization, of doctrine, and of ritual, and to the purity of life, which characterized the Christianity of the apostolic age. This common element is discernible alike in the Bogomilians of the East, and in the Albigensians, Hussites, and Lollards of the West; and in the Puritanism of later times it is conspicuous. The majestic revolt of Luther - an event which did more for true religion than anything which had happened in the world since the days of Jesus and $\mathrm{Paul}-\mathrm{can}$ in nowise be likened to the innumerable schisms which have divided the Church on special points of doctrine, organization, and ritual. Its scope and importance were far greater than any of these, important as many of these have been. It took issue with the fundamental assumption upon which the Church had come, by slow degrees, to take its stand the assumption of corporate responsibility for opinion and ceremonial. Its denial, though not explicit in every instance, was nevertheless couched in such wise as to cover implicitly the whole ground upon which the Church assumed the right to interfere with individual freedom. The protest of Luther, when its logical implications are unfolded, involves the assertion of the right of each individual to decide for himself what theological doctrines he can or cannot accept, what ecclesiastical observances he shall or shall not adopt, and generally in what way 
he is to worship God. It has, indeed, required three centuries of discussion, since Luther's time, to unfold all the logical implications of Protestantism. The theory of life which it contained was too lofty to be thoroughly and consistently understood, even by those who first conceived it distinctly enough to be willing to fight for it ; and most Protestant churches have practically retained fragments here and there of the old Romanist and quasi-pagan assumption of corporate responsibility. The struggle of the Protestant world, however, has, in the main, been a struggle in behalf of the principle of individual responsibility, and in general the most energetic Protestants have been found on the side of absolute freedom in politics, which always means absolute freedom in religion sooner or later. It was the intensely Protestant Puritans who overthrew the last attempts at tyranny on the part of English kings, both in England and in America.

It would not be correct, therefore, to describe Protestantism - any more than it would be correct to describe Christianity - as a system of doctrines. To point to any particular doctrines held in common by all Protestants would be as difficult as to point to any particular doctrines held in common by all Christians. Viewed in the light of its own historic genesis, Protestantism may be described as that kind of reli- 
gious polity which is based upon the conception of individual responsibility for opinion. The antagonist conception - of corporate responsibility for opinion - had its origin and justification in the military necessities of primeval society, when there were no political aggregates larger than the tribe. With the aggregation of men into great, complex, and stable political aggregates, - in other words, with the passing away of the circumstances by which the notion of corporate responsibility was historically justified, - the notion began to lose its hold upon men's minds. As men in the ordinary affairs of life began to proceed upon the notion of individual responsibility, they began to apply the same principle to religious matters; and great religious teachers began to protest against the various implications of the primeval notion. Such a protest was implicitly made by the Founder of Christianity, who insisted upon the importance of conduct and the worthlessness of ceremonial and formula; and fifteen centuries later, after Europe had emerged from a life and death struggle with barbarism, in which primitive notions had been partially revived and the Church had become partially paganized, a similar protest, in the name of Christ, was explicitly made by Martin Luther.

fanuary, $188 \mathrm{r}$. 


\section{$\mathbf{X}$}

\section{THE TRUE LESSON OF PROTEST- ANTISM ${ }^{1}$}

OINCE the day when Martin Luther posted his audacious heresies on the church door at Wittenberg, a great change has come over men's minds, the full significance of which is even yet but rarely comprehended. To inquire into the nature of this change, and into what we may perhaps call its ultimate tendency, is well worth our while, whether as students of history or as students of philosophy. In outward aspect, the results of Protestantism have come to be very different to-day from what they were at first. The immediate consequence of Luther's successful revolt was the formation of a great number of little churches, each with its creed as clean-cut and as thoroughly dried as the creed of the great church from which they had separated, each making practically the same assumption of absolute infallibility, each laying down an intellectual assent to sundry transcendental dogmas as an exclusive

1 An address delivered before a Convention of Unitarian clergymen at Princeton, Mass., October 4, 1881. 


\section{TRUE LESSON OF PROTESTANTISM}

condition of salvation. This formation of new sects has gone on down to the present time, and there is no reason why it should not continue in future; but the period when educated men, of great and original powers, could take part in work of this sort has gone by forever. The foremost men are no longer heresiarchs; they are free-thinkers, each on his own account; and the formation of new sects is something which in the future is likely to be more and more confined to ignorant or half-educated classes of people. At the present day it is not the formation of new sects, but the decomposition of the old ones, that is the conspicuous phenomenon inviting our attention. The latter half of the nineteenth century will be known to the future historian as especially the era of the decomposition of orthodoxies. People, as a rule, do not now pass over from one church into another, but they remain in their own churches while modifying their theological opinions, and in this way the orthodoxy of every church is gradually but surely losing its consistency. Nor is it only the laymen of whom this can be said; for the clergy every now and then set the example. An eminent Congregationalist minister in Connecticut, some few years since, was asked why he did not go over to the Unitarians, inasmuch as he not only kept Strauss and Renan in his library, but even loaned them to young 


\section{EXCURSIONS OF AN EVOLUTIONIST}

men, and publicly eulogized Herbert Spencer, and went so far one day as to take part in the dedication of a Jewish synagogue. The quaint and shrewd reply was: "I don't see why the Unitarians should monopolize all the free-thinking; I prefer to carry my candle where it is darkest!" It is only four or five years since a learned English bishop completed his voluminous commentary on the Pentateuch, in which the sacred text is handled with as much freedom as Mr. Paley shows in dealing with the Homeric poems, or Mr. Grote in expounding the dialogues of Plato. And the history of this, as of other less conspicuous acts of heresy, has been held to show that practically an Anglican divine may preach whatever doctrine he likes - provided, doubtless, that he avoid certain obnoxious catch-words. Among Unitarians this doctrinal latitude is too well known to require any illustration. Yet it is well not to forget that, forty years ago, Theodore Parker was virtually driven out of the Unitarian Church for saying the same sort of things which may be heard to-day from half the Unitarian pulpits in New England.

In view of all this, it is not strange if we are sometimes led to ask, What is to be the final outcome of this decomposition of orthodoxies? The total destruction of religious creeds was long ago predicted by Catholic controversialists 


\section{TRUE LESSON OF PROTESTANTISM}

as an inevitable result of the exercise of that right of private judgment which is the fundamental principle of Protestantism; and now it begins to look as if the Catholic prediction were likely to be fulfilled, although Protestant churches have warmly resented the imputation, and have too often taken pains to show that in strait and uncompromising bigotry they could vie with their great antagonist. While Catholics, on the one hand, have foretold this result by way of warning and opprobrium; on the other hand it has been no less confidently predicted by atheists, materialists, and positivists by way of encouragement and approval. To Comte the chaos of opinion which prevails in modern society afforded proof that the time was ripe for discarding theology and metaphysics altogether, and for confining the operations of the human mind hereafter to the simple content of observed facts. To Dr. Büchner and his friends it presages the speedy advent of that glorious millennium when all men shall felicitate themselves upon the prospect of dying like the beasts of the field. On the one side and on the other we hear it maintained, with equal emphasis, that any system of Protestantism - any system which seeks to combine absolute freedom of speculation with an essentially religious attitude of mind - is logically absurd, and is destined to be superseded. The only question is as to 


\section{EXCURSIONS OF AN EVOLUTIONIST}

what alternative is to survive the inevitable fate of all such misguided attempts; and here Dr. Büchner and the Pope will be found to disagree. While on the one hand it is held that the course of modern philosophic thought is so distinctly toward materialism that every one who is not a materialist is behind the age, on the other hand it is prophesied that, out of sheer weariness of the scepticism that is the perpetual outcome of free inquiry, there will eventually be brought about a renaissance of the ages of faith. I do not know that it can be said precisely how far these expectations go. Probably it is not expected that crusades or pilgrimages to Compostella will again become fashionable in the complex industrial society of the future; perhaps it is not expected that leaders of scientific thought will accept the miracle of St. Januarius, for the Catholic Church has oftentimes known how to be judiciously lax about such matters; but there is no doubt a vague expectation that, in spite of the independence of thought which scientific studies are fostering, a line will somehow be drawn beyond which men shall agree to submit their judgment to that of the Church. It is not Catholics only who make this tacit assumption : it is made, in one form or another, by every one who argues that his own particular orthodoxy is destined to survive the shocks of scientific scepticism; and it 


\section{TRUE LESSON OF PROTESTANTISM}

underlies the remark which we sometimes hear, that all would be well if men of science would only keep their place and not encroach upon the province of the theologian. The alternative, then, is, when stated as broadly as possible, Will the present decomposition of beliefs be succeeded by a period of reconstruction in which the teachings of some church shall be accepted as authoritative concerning questions of a purely religious nature, or will the decomposition go on until the last vestige of recognition of religious questions shall have vanished, and all educated men shall have become atheistic materialists? It is my object on the present occasion to show that no such alternative really confronts us; that the very propounding of such a question involves grave philosophical and historical errors; that neither materialism on the one hand, nor any species of ecclesiastical orthodoxy on the other hand, is likely to become prevalent in the future ; and that the maintenance of an essentially religious attitude of mind is compatible with absolute freedom of speculation on all subjects, whether scientific or metaphysical.

In my apprehension it is a very serious mistake, though a very common one, to suppose that the tendency of modern philosophic thought is toward materialism. On this subject there is a great confusion of ideas, which is aggravated by a general uncertainty as to just what materialism 


\section{EXCURSIONS OF AN EVOLUTIONIST}

really is. The word "materialism" has been so commonly used in a vituperative rather than a descriptive sense, that it has become somewhat damaged for philosophical purposes. Whenever Auguste Comte had to deal with some opinion which he did not like, - it made little or no difference what it was about, - he used to get rid of it without delay by calling it "metaphysical." And in like manner the word "materialism" has come to be with some orthodox people a general term of abuse for anything which they do not happen to like. I was once called (in print) a materialist, for saying that there are no trustworthy dates in Greek history prior to the first Olympiad! Some wiseacre - whose lectures I have lately seen reported in the newspapers - solemnly states that he shall call all persons materialists who do not believe in the freedom of the will; which, of course, would include Jonathan Edwards. Then, besides this silly use of language, the word has undergone some legitimate historical changes of meaning. The great Dr. Priestley, whose theism was quite unimpeachable, avowed himself a materialist, because he did not regard it as beyond the power of an omnipotent Creator to endow matter with the capacity for feeling and thinking. It seems to me that this was a mental attitude much more devout, if not more philosophical, than that of those modern theologians who 


\section{TRUE LESSON OF PROTESTANTISM}

vie with the ancient Gnostics in heaping abuse upon poor blind, brute, senseless, inert " matter." But Priestley was by no means a materialist in the sense in which that word is correctly used in philosophic discussion to-day. It is not merely in the vocabulary of theological abuse that the terms materialism and atheism are closely associated ; the opinions which they connote are really linked together in many ways. In former times it was customary to stigmatize the colossal generalizations of astronomers and geologists as "atheistical," because they substituted divine action through natural law for divine action through supernatural fiat, which had hitherto been commonly regarded as the only conceivable kind of divine action. Nowadays as cultivated minds are beginning to surmount this old difficulty, the bugbear springs up in a new quarter. Now that we have begun to study psychology after a scientific method, and to derive valuable assistance from the investigation of nerve-cells and nerve-fibres, and now that we have begun to apply to these studies the profoundest generalizations of phys. ics and chemistry concerning the behaviour of molecules of matter, we hear so much talk about undulations and discharges and nervous connections that many worthy people seem to be afraid of seeing it proved that we have really no psychical life at all. They are afraid that the 


\section{EXCURSIONS OF AN EVOLUTIONIST}

human soul will by and by be wholly resolved into an affair of molecules and undulations and unstable equilibria, and so forth; and accordingly all speculations even remotely savouring of physiological psychology, or of the correlation of vital with inorganic motions, are forthwith stigmatized as "materialistic." Even the Darwinian theory of the origin of species is said to be materialistic by implication, inasmuch as it is supposed at some point to derive the human soul from the psychical part of a brute animal, and at some other point to derive the psychical part of the brute animal from something that is not psychical. The common reproach aimed at all such speculations is that in one way or another, either directly or by implication, they all tend toward the interpretation of psychical life as a temporary or evanescent condition of matter, and thus in reality banish soul from the universe. The association in the popular mind between materialism and atheism is here obvious enough, and is easily justified. Philosophical materialism holds that matter and the motions of matter make up the sum total of existence, and that what we know as psychical phenomena in man and other animals are to be interpreted in an ultimate analysis as simply the peculiar aspect which is assumed by certain enormously complicated motions of matter. This is, I believe, a strictly correct description of mate- 
rialism, as it was held in the eighteenth century by La Mettrie, and as it is held by Büchner today. Whoever holds such views as these concerning the relations of matter and spirit may be properly called a materialist, and no doubt there are many educated people who hold such views, but that the general tendency of modern philosophic thought is toward the adoption of materialism as thus defined, I emphatically deny. On the contrary, it seems to me that the course of modern philosophy is distinctly in the opposite direction, and that materialism is hopelessly behind the age, so that it argues a much more superficial mind and a much more imperfect education to agree with Büchner to-day than to have agreed with La Mettrie a hundred years ago.

Bear in mind that, before a philosopher can be correctly charged with materialism, it is absolutely necessary that he should hold that psychical phenomena - such as love and hate, or the sensation of redness, or the idea of virtue - are interpretable in terms of matter and motion. Nothing short of this will do. It is not enough that he should hold that, along with every emotion or sensation or idea, there goes on a change in nerve-tissue which is probably resolvable into some form of undulatory motion; for this is but an amplification of what we all begin by admitting when we admit that 


\section{EXCURSIONS OF AN EVOLUTIONIST}

during the present life there is no consciousness except where there is nerve-tissue. If it is materialism to say that for every association of ideas there is established a system of paths for discharges between two or more groups of nerve-cells, it is equally materialism to say that a pint of Scotch whiskey will make a man drunk. The former statement enters very much more into detail than the latter, but there is no other essential difference between them. I do not wonder, however, that people's minds are often vague and confused on these points, for our every-day talk is full of materialistic implications. We say, for example, that grief makes us weep, and the statement is true enough for ordinary purposes; but, in reality, it is not the grief that acts upon the tear-glands. The grief is something absolutely immaterial, something absolutely outside the circuit of physical causation. How do we know this? How do we reach such a conclusion? We reach it by applying to the subject the conception of the correlation of forces, and the conception of the atomic constitution of matter, - twin conceptions which lie at the bottom of all our modern scientific reasoning. The material world is all made up of systems of atoms that are perpetually moving in relation to one another. In an ultimate analysis, every material object is such a system of moving atoms. Every living organism is a 


\section{TRUE LESSON OF PROTESTANTISM}

system of systems of such atoms, in myriad-fold orders of composition, and with movements definitely coördinated in myriad-fold degrees of complexity. Now, all the motion that goes into any organism, latent in the air which it breathes and the food which it assimilates, must come out again as motion, and what comes out must be the exact equivalent of what goes in. This is what the doctrine of the correlation of forces means when applied to the living organism and to the nervous system. It means, too, that if we were able to trace in detail the career of any given quantity of atomic motion between the times of its entering and its leaving the organism, we should find through all its innumerable transformations an exact equivalence preserved. But this means that the motion must always be a motion of material particles, - something that can be quantitatively measured. Once introduce into the circuit something that does not admit of material measurement, such as a sensation of colour, or an emotion of grief, and the whole theory falls to the ground at once.

When a given quantity of atomic motion in the gray surface of the brain is used up, its equivalent must appear in the form of some other atomic motion, and cannot have been a subjective feeling; otherwise it is idle to talk about any correlation and equivalence of forces in the case. There can be no relation of equiv- 
alence between a sorrowful feeling and a motion of matter that can be expressed in terms of footpounds. You might as well talk about a crimson taste or an acid sound. When you weep, therefore, it is not grief, but the cerebrum, that acts upon the tear-glands. You say that the grief causes the tears, because you are conscious of the relation of sequence between the subjective emotion and the objective flow of tears, while you are totally unconscious of the molecular movements going on in the brain. But, in reality, the subjective emotion is something purely immaterial, or, if you choose to say so, spiritual, and its relation to what goes on in the brain is merely a relation of concomitance.

I have illustrated this point at disproportionate length, because it is both important and difficult. Until this point is perfectly clear in one's mind, any discussion of the alleged materialistic tendencies of modern philosophy is simply a waste of words. It is very clear that modern philosophy does show a decided tendency toward investigating what goes on in the nervous system when we think and feel; and it is also clear that modern philosophy considers itself bound to study the nervous system as a material aggregate, with an atomic constitution, and subject to the same physical laws with other matter. I hope I have now made it equally clear that these tendencies of modern philoso- 


\section{TRUE LESSON OF PROTESTANTISM}

phy are just the reverse of materialistic. So far from maintaining, as materialism does, that psychical phenomena are interpretable in terms of matter and motion, this modern philosophy maintains that such phenomena are absolutely immaterial, - that they stand, as I said before, quite outside the circuit of physical causation. If the world were peopled with automata, if men had gone on from the beginning like puppets, eating, and drinking, and marrying, working and fighting, exactly as they have done, producing human history in all its details exactly as it has been produced, only without any consciousness, without any sentient life whatever, then materialism perhaps would afford a satisfactory explanation of the world. But the moment the first trace of conscious intelligence is introduced, we have a set of phenomena which materialism can in no wise account for. The latest and ripest philosophic speculation, therefore, leaves the gulf between mind and matter quite as wide and impassable as it appeared in the time of Descartes.

But while materialism is thus more than ever discredited by the dominant philosophy of our time, and while it will no doubt continue to be more and more discredited with each future advance in philosophic speculation, I see no reason why there should not always be a certain amount of materialism current in the world. 


\section{EXCURSIONS OF AN EVOLUTIONIST}

Very likely there will always be people who are colour-blind, and people without an ear for music. So, doubtless, there will always be a class of excellent people with a fair capacity for understanding scientific generalizations, but without any head for philosophy ; and this class will produce the Büchners and La Mettries of the future, as it has produced them in the past and present. Thus, one part of my question is disposed of. The philosophy of the future will not be materialistic, and there is nothing in the dominant philosophy of to-day to indicate that religious problems will not continue to be made the subjects of speculation. I recollect once asking Mr. Spencer's opinion on some question of pure ontology. He replied that he had no opinion; not because his mind was necessarily hostile to entertaining such questions, but simply because he was so entirely occupied in working out the theory of evolution, in its innumerable applications to the world of phenomena, that he had not time and strength left to expend on problems that are confessedly insoluble. This was the answer of a true man of science; and it is worth repeating for the benefit of those silly people who think it is not enough that Mr. Spencer should have made greater additions to the sum of human knowledge than have ever been made by any other man since the beginning of the world, and complain of 


\section{TRUE LESSON OF PROTESTANTISM}

him because he has not given us a complete and final system of theology into the bargain. But Mr. Spencer's answer further illustrates very well the philosophic attitude of the present age. The present age is occupied, above all things, in investigating the intimate constitution of the material universe, and tracing therefrom its past history and its future career. The conception of evolution is everywhere being substituted for that of special creation; and this involves the most extensive and thorough change that has ever taken place in men's thoughts about the world they live in. For the present, this business absorbs all the most active and original minds, so that no time is left for metaphysical speculations. We are becoming wrapt in the study of origins, as the men of the thirteenth century were wrapt in the study of particulars and universals. But there is no likelihood that this will always be so. By and by all educated people will be evolutionists, and then it will be seen, more clearly than it is now, that while the doctrine of evolution has enormously increased our knowledge of the phenomenal universe, it really leaves all ultimate questions as much open for discussion as they ever were. It is Mr. Spencer himself who has said that every new physical problem leads at once to a metaphysical problem that we can neither solve nor elude. Solve it doubtless we cannot, elude it we also 
cannot, and so discuss it we will. Such, I presume, will be the course which philosophy will take where religious questions are concerned.

And now we are brought to the other part of my question. Will the time ever come again when men will be absorbed in questions of a transcendental or ontological character, as Aquinas and other great mediæval thinkers were absorbed? It seems to me quite possible that the interest in such matters may again become as intense, though not so exclusive, as it was in the Middle Ages. But if it be asked whether there can ever again be a theological renaissance of such a character that men shall agree to surrender their right of private judgment on purely religious questions, and accept the teachings of any church, the reply must be that any renaissance of this sort is utterly impossible. The further question, whether unity of belief can ever be secured in any other way, is to be met by the assertion that unity of belief is no longer either possible or desirable. Such a statement as this is very startling, and more or less puzzling; to many people, as I have often had occasion to observe; and when the truth of it has come to be generally and thoroughly realized, it will probably be the greatest step in religious progress that has ever been accomplished. Once, we know, unity of belief was held to be of such supreme importance that the faintest whisper 260 
of dissent must be punished with torture and death. I have elsewhere sought to account, on historical grounds, for the existence of this persecuting spirit, as well as for its decline in modern times. In a paper on "The Causes of Persecution," I showed how ancient society was pervaded by an intense feeling of corporate responsibility, - a feeling that the whole community was liable to be punished by the gods for the misdeeds of any one of its individual members. In early times this feeling of corporate responsibility, taken in connection with the barbaric theories of the universe then current, was the mainstay and support of priesthoods. And it was to the persistence of this feeling down through the Middle Ages that the horrors of religious persecution were chiefly due. In a second paper, on "The Origins of Protestantism," I showed that the feeling of corporate responsibility had its legitimate origin in the military necessities of primitive societies. In ages when there were no political aggregations of men larger than tribes, and when the relations between tribes were chiefly those of chronic warfare, a rude and savage discipline, in which the legal existence of the individual was virtually submerged in the interests of the tribe, was absolutely necessary. The feeling that the whole tribe was liable to be visited with defeat or famine or pestilence, on account of sac26 I 
rilege committed by one of its members, was part and parcel of such a state of society. This feeling of corporate responsibility must have grown in strength through many ages by natural selection, as those tribes in which it was most effectively developed must in general have shown the highest capacity for social organization, and must have exterminated or enslaved their neighbours. Having so long been favoured by natural selection, the feeling of corporate responsibility for conduct and opinion became so deeply grounded in men's minds that it long survived the stage of social development in which it had its origin. Most conspicuous and terrible of the consequences of this deeply rooted feeling has been that fanatical craving for unity of belief in religious matters which has been the source of some of the worst evils that have afflicted mankind. But among the many changes which have affected the relations of the individual to the community, with the growth of great and complex modern societies, there has come the gradual substitution of the idea of individual responsibility for that of corporate responsibility. From this point of view, the Protestantism of Luther is significant mainly as a revolt against primeval notions of the relations of the individual to the community, which have long since survived their usefulness. Obviously, the disintegration of orthodoxies which characterizes 262 


\section{TRUE LESSON OF PROTESTANTISM}

the present age is simply the further development of the same protest in behalf of individual responsibility for opinion. And to those who take any interest in the present discussion, I hardly need argue that any revival of the methods of Catholicism could never occur, except as the concomitant of a wholly improbable retrogression of society toward the barbaric type. The very conception of an infallible church is so clearly a survival from primitive religious ideas, that to imagine such an institution presiding over the society of the future involves a most grotesque anachronism. Nevertheless, the uses of the Catholic Church are such that it is likely still to survive for a very long time, though with diminishing influence; and as it affords a refuge for such earnest and thoughtful souls as find the atmosphere of free discussion too bracing, it will probably long continue to receive accessions from the ranks of the various Protestant orthodoxies that are now so rapidly disintegrating.

With the fading away of the old notion of corporate responsibility for opinion, the value attached to unity of belief has greatly diminished, and attempts to secure such unity by violent means have become generally discredited. It is at last beginning to be apprehended that if unity of belief is to have any real value, it can only be when it is the result of the free working of differ263 


\section{EXCURSIONS OF AN EVOLUTIONIST}

ent minds. But unity of belief in religious matters is not very likely to be reached in any such way, for the conditions of the case are totally different from those of scientific discussion. The difference may be best appreciated by recalling the useful distinction drawn by positivism between science and metaphysics. According to positivism, the essential distinction between a scientific hypothesis, such as the undulatory theory of light, and a metaphysical hypothesis, such as the Leibnitzian theory of preëstablished harmony, is that the one admits of verification whether by observation, experiment, or deduction - while the other does not. Or, from another point of view, the one may be made a working hypothesis from which independent inquirers will arrive at mutually congruous results, while the other cannot. This distinction is one of the very few points made by positivism which have been generally adopted into modern philosophy ; but the use which positivists have made of it is by no means philosophical. Comte himself set an inordinate value upon unity of belief, and in this his disciples have generally followed him; and the way in which they propose to secure such unity is simply to ignore all problems whatever in which scientific methods of demonstration are not accessible. This seems like paying an exorbitant price for a privilege of very doubtful value. But without following the pos- 


\section{TRUE LESSON OF PROTESTANTISM}

itivists in this, we may admit the usefulness of their distinction between problems that transcend the limits of scientific demonstration and problems that lie within those limits. Clearly, if I hold one opinion concerning the passage of light through certain crystals, and my neighbour holds a different or contrary opinion, I am entitled to expect either that he can be brought to adopt my opinion, or that I can be brought to adopt his. Means of verification must exist; and even if the question cannot be settled today, we have no doubt that it can be settled by and by. But if I hold one opinion concerning the conscious existence of the soul after death, while my neighbour holds a contrary opinion, I am not entitled to expect that we can ever be brought to an agreement. For the question confessedly transcends the limits of scientific demonstration. Yet in spite of all that, one of our contrary opinions, and possibly both, may contain some adumbration of a truth. And more than a faint glimmering of truth we can hardly expect to be contained in any of our opinions on religious matters, for the problems are too vast when compared with our means of dealing with them. Hence, instead of condemning variety of belief on such subjects, we should rather welcome each fresh suggestion as possibly containing some adumbration of a truth which we have hitherto overlooked. 


\section{EXCURSIONS OF AN EVOLUTIONIST}

And thus we arrive at last at the true lesson of Protestantism, which is simply this : that religious belief is something which in no way concerns society, but which concerns only the individual. In all other relations the individual is more or less responsible to society ; but, as for his religious belief and his religious life, these are matters which lie solely between himself and his God. On such subjects no man may rightfully chide his neighbour, or call him foolish; for, in presence of the transcendent Reality, the foolishness of one man differs not much from the wisdom of another. When this lesson shall have been duly comprehended and taken to heart, I make no doubt that religious speculation will continue to go on : but such words as "infidelity" and "heresy," the present currency of which serves only to show how the remnants of primitive barbaric thought still cling to us and hamper our progress - such words will have become obsolete, and perhaps unintelligible, save to the philosophic student of history. In discussion conducted in such a mood, there will, no doubt, be a great lack of finality. But the craving for finality is itself, in various degrees, an instinct of the uneducated man, of the child, of the savage, and perhaps of the brute. To feel that the last word has been said on any subject is not a desideratum with the true philosopher, who knows full well that the truth he announces to- 


\section{TRUE LESSON OF PROTESTANTISM}

day will open half a dozen questions where it settles one, and will presently be variously qualified, and at last absorbed in some wider and deeper truth. When all this shall have come to be realized, and shall have been made part and parcel of the daily mental habit of men, then our human treatment of religion will no longer be what it has too often been in the past, - a wretched squabble, fit only for the demons of Malebolge, - but it will have come to be like the sweet discourse of saints in Dante's "Paradise."

September, 1881 . 


\section{XI}

\section{EVOLUTION AND RELIGION ${ }^{1}$}

$1 \begin{aligned} & \text { R. PRESIDENT: }{ }^{2} \text { The thought } \\ & \text { which you have uttered suggests so } \\ & \text { many and such fruitful themes of dis- }\end{aligned}$ cussion that a whole evening would not suffice to enumerate them, while to illustrate them properly would seem to require an octavo volume rather than a talk of six or eight minutes, especially when such a talk comes just after dinner. The Amazulu saying which you have cited, that those who have "stuffed bodies" cannot see hidden things, seems peculiarly applicable to any attempt to discuss the mysteries of religion at the present moment; and, after the additional warning we have just had from our good friend Mr. Schurz, I hardly know whether I ought to venture to approach so vast a theme. There are one or two points of signal importance, however, to which I may at least call attention for a moment. It is a matter which has long since taken deep hold of my mind, and I

1 Speech at the farewell dinner given to Herbert Spencer, in New York, November 9, 1882 .

2 Hon. W. M. Evarts. 


\section{EVOLUTION AND RELIGION}

am glad to have a chance to say something about it on so fitting an occasion. We have met here this evening to do homage to a dear and noble teacher and friend, and it is well that we should choose this time to recall the various aspects of the immortal work by which he has earned the gratitude of a world. The work which Herbert Spencer has done in organizing the different departments of human knowledge, so as to present the widest generalizations of all the sciences in a new and wonderful light, as flowing out of still deeper and wider truths concerning the universe as a whole; the great number of profound generalizations which he has established incidentally to the pursuit of this main object; the endlessly rich and suggestive thoughts which he has thrown out in such profusion by the wayside all along the course of this great philosophical enterprise, - all this work is so manifest that none can fail to recognize it. It is work of the calibre of that which Aristotle and Newton did. Though coming in this latter age, it as far surpasses their work in its vastness of performance as the railway surpasses the sedan-chair, or as the telegraph surpasses the carrier-pigeon.

But it is not of this side of our teacher's work that I wish to speak, but of a side of it that has hitherto met with less general recognition. There are some people who seem to think that it is 269 


\section{EXCURSIONS OF AN EVOLUTIONIST}

not enough that Mr. Spencer should have made all these priceless contributions to human knowledge, but actually complain of him for not giving us a complete and exhaustive system of theology into the bargain. What I wish, therefore, to point out is that Mr. Spencer's work on the side of religion will be seen to be no less important than his work on the side of science, when once its religious implications shall have been fully and consistently unfolded.

If we look at all the systems or forms of religion of which we have any knowledge, we shall find that they differ in many superficial features. They differ in many of the transcendental doctrines which they respectively preach, and in many of the rules of conduct which they respectively lay down for men's guidance. They assert different things about the universe, and they enjoin or prohibit different kinds of behaviour on the part of their followers. The doctrine of the Trinity, which to many Christians is the most sacred of mysteries, is to all Mohammedans the foulest of blasphemies. The Brahman's conscience would be more troubled if he were to kill a cow by accident than if he were to swear to a lie or steal a purse. The Turk, who sees no wrong in bigamy, would shrink from the sin of eating pork. But, amid all such surface differences we find throughout all known religions two points of substantial 


\section{EVOLUTION AND RELIGION}

agreement. And these two points of agreement will be admitted by modern civilized men to be of far greater importance than the innumerable differences of detail. All religions agree in the two following assertions, one of which is of speculative and one of which is of ethical import. One of them serves to sustain and harmonize our thoughts about the world we live in and our place in that world; the other serves to uphold us in our efforts to do each what we can to make human life more sweet, more full of goodness and beauty, than we find it. The first of these assertions is the proposition that the things and events of the world do not exist or occur blindly or irrelevantly, but that all, from the beginning to the end of time, and throughout the farthest sweep of illimitable space, are connected together as the orderly manifestations of a divine Power, and that this divine Power is something outside of ourselves, and upon it our own existence from moment to moment depends. The second of these assertions is the proposition that men ought to do certain things, and ought to refrain from doing certain other things; and that the reason why some things are wrong to do and other things are right to do is in some mysterious but very real way connected with the existence and nature of this divine Power, which reveals itself in every great and every tiny thing, without which not a 


\section{EXCURSIONS OF AN EVOLUTIONIST}

star courses in its mighty orbit, and not a sparrow falls to the ground. Matthew Arnold once summed up these two propositions very well, when he defined God as "an eternal Power, not ourselves, that makes for righteousness." This twofold assertion, that there is an eternal Power that is not ourselves, and that this Power makes for righteousness, is to be found, either in a rudimentary or in a highly developed state, in all known religions. In such religions as those of the Eskimos or of your friends, the Amazulus, Mr. President, this assertion is found in a rudimentary shape on each of its two sides, the speculative side and the ethical side; in such religions as Buddhism or Judaism, it is found in a highly developed shape on both its sides. But the main point is that in all religions you find it in some shape or other.

I said, a moment ago, that modern civilized men will all acknowledge that this two-sided assertion in which all religions agree is of far greater importance than any of the superficial points in which religions differ. It is really of much more concern to us that there is an eternal Power, not ourselves, that makes for righteousness, than that such a Power is onefold or threefold in its metaphysical nature, or that we ought not to play cards on Sunday or to eat meat on Friday. No one, I believe, will deny so simple and clear a statement as this. But it 


\section{EVOLUTION AND RELIGION}

is not only we modern men, who call ourselves enlightened, that will agree to this. I doubt not even the narrow-minded bigots of days now happily gone by would have been made to agree to it, if they could have had some doggedly persistent Sokrates to cross-question them. Calvin was willing to burn Servetus for doubting the doctrine of the Trinity, but I do not suppose that even Calvin would have argued that the belief in God's threefold nature was more fundamental than the belief in his existence and his goodness. The philosophical error with him was that he could not dissociate the less important doctrine from the more important doctrine, and the fate of the latter seemed to him wrapped up with the fate of the former. I cite this merely as a typical example. What men in past times have really valued in their religion has been the universal twofold assertion that there is a God who is pleased by the sight of the just man and is angry with the wicked every day; and when men have fought with one another, and murdered or calumniated one another for heresy about the Trinity or about eating meat on Friday, it has been because they have supposed belief in the non-essential doctrines to be inseparably connected with belief in the essential doctrine. In spite of all this, however, it is true that in the mind of the uncivilized man the great central truths of religion are so densely 


\section{EXCURSIONS OF AN EVOLUTIONIST}

overlaid with hundreds of trivial notions respecting dogma and ritual that his perception of the great central truths is obscure. These great central truths, indeed, need to be clothed in a dress of little rites and superstitions, in order to take hold of his dull and untrained intelligence. But, in proportion as men become more civilized, and learn to think more accurately, and to take wider views of life, just so do they come to value the essential truths of religion more highly, while they attach less and less importance to superficial details.

Having thus seen what is meant by the essential truths of religion, it is very easy to see what the attitude of the doctrine of evolution is toward these essential truths. It asserts and reiterates them both; and it asserts them not as dogmas handed down to us by priestly tradition, not as mysterious intuitive convictions of which we can render no intelligible account to ourselves, but as scientific truths concerning the innermost constitution of the universe, truths that have been disclosed by observation and reflection, like other scientific truths, and that accordingly harmonize naturally and easily with the whole body of our knowledge. The doctrine of evolution asserts, as the widest and deepest truth which the study of nature can disclose to us, that there exists a Power to which no limit in time or space is conceivable, and that all the 
phenomena of the universe, whether they be what we call material or what we call spiritual phenomena, are manifestations of this infinite and eternal Power. Now, this assertion, which Mr. Spencer has so elaborately set forth as a scientific truth, - nay, as the ultimate truth of science, as the truth upon which the whole structure of human knowledge philosophically rests, - this assertion is identical with the assertion of an eternal Power, not ourselves, that forms the speculative basis of all religions. When Carlyle speaks of the universe as in very truth the star-domed city of God, and reminds us that through every crystal and through every grassblade, but most through every living soul, the glory of a present God still beams, he means pretty much the same thing that Mr. Spencer means, save that he speaks with the language of poetry, with language coloured by emotion, and not with the precise, formal, and colourless language of science. By many critics who forget that names are but the counters rather than the hard money of thought, objections have been raised to the use of such a phrase as the Unknowable whereby to describe the power that is manifested in every event of the universe. Yet, when the Hebrew prophet declared that "by Him were laid the foundations of the deep," but reminded us, "Who by searching can find Him out?" he meant pretty much what $\mathrm{Mr}$. 


\section{EXCURSIONS OF AN EVOLUTIONIST}

Spencer means when he speaks of a Power that is inscrutable in itself, yet is revealed from moment to moment in every throb of the mighty rhythmic life of the universe.

And this brings me to the last and most important point of all. What says the doctrine of evolution with regard to the ethical side of this twofold assertion that lies at the bottom of all religion? Though we cannot fathom the nature of the inscrutable Power that animates the world, we know, nevertheless, a great many things that it does. Does this eternal Power, then, work for righteousness? Is there a divine sanction for holiness and a divine condemnation for sin? Are the principles of right living really connected with the intimate constitution of the universe? If the answer of science to these questions be affirmative, then the agreement with religion is complete, both on the speculative and on the practical sides; and that phantom which has been the abiding terror of timid and superficial minds - that phantom of the hostility between religion and science - is exorcised now and forever.

Now science began to return a decisively affirmative answer to such questions as these, when it began, with Mr. Spencer, to explain moral beliefs and moral sentiments as products of evolution. For clearly, when you say of a moral belief or a moral sentiment that it is a 


\section{EVOLUTION AND RELIGION}

product of evolution, you imply that it is something which the universe through untold ages has been labouring to bring forth, and you ascribe to it a value proportionate to the enormous effort that it has cost to produce it. Still more, when with Mr. Spencer we study the principles of right living as part and parcel of the whole doctrine of the development of life upon the earth; when we see that, in an ultimate analysis, that is right which tends to enhance fulness of life, and that is wrong which tends to detract from fulness of life, - we then see that the distinction between right and wrong is rooted in the deepest foundations of the universe; we see that the very same forces, subtle and exquisite and profound, which brought upon the scene the primal germs of life and caused them to unfold, which through countless ages of struggle and death have cherished the life that could live more perfectly and destroyed the life that could only live less perfectly, until $\mathrm{Hu}-$ manity, with all its hopes and fears and aspirations, has come into being as the crown of all this stupendous work, - we see that these very same subtle and exquisite forces have wrought into the very fibres of the universe those principles of right living which it is man's highest function to put into practice. The theoretical sanction thus given to right living is incomparably the most powerful that has ever been as- 


\section{EXCURSIONS OF AN EVOLUTIONIST}

signed in any philosophy of ethics. Human responsibility is made more strict and solemn than ever, when the eternal Power that lives in every event of the universe is thus seen to be in the deepest possible sense the author of the moral law that should guide our lives, and in obedience to which lies our only guarantee of the happiness which is incorruptible, - which neither inevitable misfortune nor unmerited obloquy can ever take away.

I have here but barely touched upon a rich and suggestive topic. When this subject shall once have been expounded and illustrated with due thoroughness, - as I earnestly hope it will be within the next few years, - then I am sure it will be generally acknowledged that our great teacher's services to religion have been no less signal than his services to science, unparalleled as these have been in all the history of the world. November, 1882. 


\section{XII}

\section{THE MEANING OF INFANCY ${ }^{1}$}

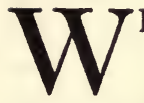

HAT is the Meaning of Infancy? What is the meaning of the fact that man is born into the world more helpless than any other creature, and needs for a much longer season than any other living thing the tender care and wise counsel of his elders? It is one of the most familiar of facts that man, alone among animals, exhibits a capacity for progress. That man is widely different from other animals in the length of his adolescence and the utter helplessness of his babyhood is an equally familiar fact. Now between these two commonplace facts is there any connection? Is it a mere accident that the creature which is distinguished as progressive should also be distinguished as coming slowly to maturity, or is there a reason lying deep down in the nature of things why

1 A very brief restatement, in simple language, of the main points of the theory of man's origin first suggested in my lectures at Harvard University in 1871 , and worked out in Outlines of Cosmic Philosophy, part ii., chapters xvi., xxi., and xxii. [See also The Destiny of Man for an amplification.] 
this should be so? I think it can be shown, with very few words, that between these two facts there is a connection that is deeply inwrought with the processes by which life has been evolved upon the earth. It can be shown that man's progressiveness and the length of his infancy are but two sides of one and the same fact; and in showing this, still more will appear. It will appear that it was the lengthening of infancy which ages ago gradually converted our forefathers from brute creatures into human creatures. It is babyhood that has made man what he is. The simple unaided operation of natural selection could never have resulted in the origination of the human race. Natural selection might have gone on forever improving the breed of the highest animal in many ways, but it could never unaided have started the process of civilization or have given to man those peculiar attributes in virtue of which it has been well said that the difference between him and the highest of apes immeasurably transcends in value the difference between an ape and a blade of grass. In order to bring about that wonderful event, the Creation of Man, natural selection had to call in the aid of other agencies, and the chief of these agencies was the gradual lengthening of babyhood.

Such is the point which I wish to illustrate in few words, and to indicate some of its bear- 


\section{THE MEANING OF INFANCY}

ings on the history of human progress. Let us first observe what it was that lengthened the infancy of the highest animal, for then we shall be the better able to understand the character of the prodigious effects which this infancy has wrought. A few familiar facts concerning the method in which men learn how to do things will help us here.

When we begin to learn to play the piano, we have to devote much time and thought to the adjustment and movement of our fingers and to the interpretation of the vast and complicated multitude of symbols which make up the printed page of music that stands before us. For a long time, therefore, our attempts are feeble and stammering and they require the full concentrated power of the mind. Yet a trained pianist will play a new piece of music at sight, and perhaps have so much attention to spare that he can talk with you at the same time. What an enormous number of mental acquisitions have in this case become almost instinctive or automatic! It is just so in learning a foreign language, and it was just the same when in childhood we learned to walk, to talk, and to write. It is just the same, too, in learning to think about abstruse subjects. What at first strains the attention to the utmost, and often wearies us, comes at last to be done without effort and almost unconsciously. Great minds 


\section{EXCURSIONS OF AN EVOLUTIONIST}

thus travel over vast fields of thought with an ease of which they are themselves unaware. Dr. Nathaniel Bowditch once said that in translating the "Mécanique Céleste," he had come upon formulas which Laplace introduced with the word "obviously," where it took nevertheless many days of hard study to supply the intermediate steps through which that transcendent mind had passed with one huge leap of inference. At some time in his youth no doubt Laplace had to think of these things, just as Rubinstein had once to think how his fingers should be placed on the keys of the piano; but what was once the object of conscious attention comes at last to be well-nigh automatic, while the flight of the conscious mind goes on ever to higher and vaster themes.

Let us now take a long leap from the highest level of human intelligence to the mental life of a turtle or a codfish. In what does the mental life of such creatures consist? It consists of a few simple acts mostly concerned with the securing of food and the avoiding of danger, and these few simple acts are repeated with unvarying monotony during the whole lifetime of these creatures. Consequently these acts are performed with great ease and are attended with very little consciousness, and moreover the capacity to perform them is transmitted from parent to offspring as completely as the capacity 


\section{THE MEANING OF INFANCY}

of the stomach to digest food is transmitted. In all animals the new-born stomach needs but the contact with food in order to begin digesting, and the new-born lungs need but the contact with air in order to begin to breathe. The capacity for performing these perpetually repeated visceral actions is transmitted in perfection. All the requisite nervous connections are fully established during the brief embryonic existence of each creature. In the case of lower animals it is almost as much so with the few simple actions which make up the creature's mental life. The bird known as the fly-catcher no sooner breaks the egg than it will snap at and catch a fly. This action is not so very simple, but because it is something the bird is always doing, being indeed one out of the very few things that this bird ever does, the nervous connections needful for doing it are all established before birth, and nothing but the presence of the fly is required to set the operation going.

With such creatures as the codfish, the turtle, or the fly-catcher, there is accordingly nothing that can properly be called infancy. With them the sphere of education is extremely limited. They get their education before they are born. In other words, heredity does everything for them, education nothing. The career of the individual is predetermined by the careers of his 283 


\section{EXCURSIONS OF AN EVOLUTIONIST}

ancestors, and he can do almost nothing to vary it. The life of such creatures is conservatism cut and dried, and there is nothing progressive about them.

- In what I just said I left an " almost." There is a great deal of saving virtue in that little adverb. Doubtless even animals low in the scale possess some faint traces of educability; but they are so very slight that it takes geologic ages to produce an appreciable result. In all the innumerable wanderings, fights, upturnings and cataclysms of the earth's stupendous career, each creature has been summoned under penalty of death to use what little wit he may have had, and the slightest trace of mental flexibility is of such priceless value in the struggle for existence that natural selection must always have seized upon it, and sedulously hoarded and transmitted it for coming generations to strengthen and increase. With the lapse of geologic time the upper grades of animal intelligence have doubtless been raised higher and higher through natural selection. The warm-blooded mammals and birds of to-day no doubt surpass the coldblooded dinosaurs of the Jurassic age in mental qualities as they surpass them in physical structure. From the codfish and turtle of ancient family to the modern lion, dog, and monkey, it is a very long step upward. The mental life of a warm-blooded animal is a very different affair 284 


\section{THE MEANING OF INFANCY}

from that of reptiles and fishes. A squirrel or a bear does a good many things in the course of his life. He meets various vicissitudes in various ways; he has adventures. The actions he performs are so complex and so numerous that they are severally performed with less frequency than the few actions performed by the codfish. The requisite nervous connections are accordingly not fully established before birth. There is not time enough. The nervous connections needed for the visceral movements and for the few simple instinctive actions get organized, and then the creature is born before he has learned how to do all the things his parents could do. A good many of his nervous connections are not yet formed, they are only formable. Accordingly he is not quite able to take care of himself; he must for a time be watched and nursed. All mammals and most birds have thus a period of babyhood that is not very long, but is on the whole longest with the most intelligent creatures. It is especially long with the higher monkeys, and among the man-like apes it becomes so long as to be strikingly suggestive. An infant orangoutang, captured by Mr. Wallace, was still a helpless baby at the age of three months, unable to feed itself, to walk without aid, or to grasp objects with precision.

But this period of helplessness has to be viewed under another aspect. It is a period of 285 


\section{EXCURSIONS OF AN EVOLUTIONIST}

plasticity. The creature's career is no longer exclusively determined by heredity. There is a period after birth when its character can be slightly modified by what happens to it after birth, that is, by its experience as an individual. It becomes educable. It is no longer necessary for each generation to be exactly like that which has preceded. A door is opened through which the capacity for progress can enter. Horses and dogs, bears and elephants, parrots and monkeys, are all teachable to some extent, and we have even heard of a learned pig. Of learned asses there has been no lack in the world.

But this educability of the higher mammals and birds is after all quite limited. By the beginnings of infancy the door for progressiveness was set ajar, but it was not all at once thrown wide open. Conservatism still continued in fashion. One generation of cattle is much like another. It would be easy for foxes to learn to climb trees, and many a fox might have saved his life by doing so; yet quick-witted as he is, this obvious device never seems to have occurred to Reynard. Among slightly teachable mammals, hnwever, there is one group more teachable than the rest. Monkeys, with their greater power of handling things, have also more inquisitiveness and more capacity for sustained attention than any other mammals; and the higher apes are fertile in varied resources. The orang286 


\section{THE MEANING OF INFANCY}

outang and gorilla are for this reason dreaded by other animals, and roam the undisputed lords of their native forests. They have probably approached the critical point where variations in intelligence, always important, have come to be supremely important, so as to be seized by natural selection in preference to variations in physical constitution. At some remote epoch of the past - we cannot say just when or how - our half-human forefathers reached and passed this critical point, and forthwith their varied struggles began age after age to result in the preservation of bigger and better brains, while the rest of their bodies changed but little. This particular work of natural selection must have gone on for an enormous length of time, and as its result we see that while man remains anatomically much like an ape, he has acquired a vastly greater brain with all that this implies. Zoölogically the distance is small between man and the chimpanzee; psychologically it has become so great as to be immeasurable.

But this steady increase of intelligence, as our forefathers began to become human, carried with it a steady prolongation of infancy. As mental life became more complex and various, as the things to be learned kept ever multiplying, less and less could be done before birth, more and more must be left to be done in the earlier years of life. So instead of being born with a few sim287 


\section{EXCURSIONS OF AN EVOLUTIONIST}

ple capacities thoroughly organized, man came at last to be born with the germs of many complex capacities which were reserved to be unfolded and enhanced or checked and stifled by the incidents of personal experience in each individual. In this simple yet wonderful way there has been provided for man a long period during which his mind is plastic and malleable, and the length of this period has increased with civilization until it now covers nearly one third of our lives. It is not that our inherited tendencies and aptitudes are not still the main thing. It is only that we have at last acquired great power to modify them by training, so that progress may go on with ever increasing sureness and rapidity.

In thus pointing out the causes of infancy, we have at the same time witnessed some of its effects. One effect, of stupendous importance, remains to be pointed out. As helpless babyhood came more and more to depend on parental care, the correlated feelings were developed on the part of parents, and the fleeting sexual relations established among mammals in general were gradually exchanged for permanent relations. A cow feels strong maternal affection for her nursing calf, but after the calf is fully grown, though doubtless she distinguishes it from other members of the herd, it is not clear that she entertains for it any parental feel288 


\section{THE MEANING OF INFANCY}

ing. But with our half-human forefathers it is not difficult to see how infancy extending over several years must have tended gradually to strengthen the relations of the children to the mother, and eventually to both parents, and thus give rise to the permanent organization of the family. When this step was accomplished we may say that the Creation of Man had been achieved. For through the organization of the family has arisen that of the clan or tribe, which has formed, as it were, the cellular tissue out of which the most complex human society has come to be constructed. And out of that subordination of individual desires to the common interest, which first received a definite direction when the family was formed, there grew the rude beginnings of human morality.

It was thus through the lengthening of his infancy that the highest of animals came to be Man, - a creature with definite social relationships and with an element of plasticity in his organization such as has come at last to make his difference from all other animals a difference in kind. Here at last there had come upon the scene a creature endowed with the capacity for progress, and a new chapter was thus opened in the history of creation. But it was not to be expected that man should all at once learn how to take advantage of this capacity. Nature, which is said to make no jumps, surely did not 289 
jump here. The whole history of civilization, indeed, is largely the history of man's awkward and stumbling efforts to avail himself of this flexibility of mental constitution with which God has endowed him. For many a weary age the progress men achieved was feeble and halting. Though it had ceased to be physically necessary for each generation to tread exactly in the steps of its predecessor, yet the circumstances of primitive society long made it very difficult for any deviation to be effected. For the tribes of primitive men were perpetually at war with each other, and their methods of tribal discipline were military methods. To allow much freedom of thought would be perilous, and the whole tribe was supposed to be responsible for the word: and deeds of each of its members. The tribes most rigorous in this stern discipline were those which killed out tribes more loosely organized, and thus survived to hand down to coming generations their ideas and their methods. From this state of things an intense social conservatism was begotten, - a strong disposition on the part of society to destroy the flexible-minded individual who dares to think and behave differently from his fellows. During the past three thousand years much has been done to weaken this conservatism by putting an end to the state of things which produced it. As great and strong societies have arisen, as the sphere of 


\section{THE MEANING OF INFANCY}

warfare has diminished while the sphere of industry has enlarged, the need for absolute conformity has ceased to be felt, while the advantages of freedom and variety come to be ever more clearly apparent. At a late stage of civilization, the flexible or plastic society acquires even a military advantage over the society that is more rigid, as in the struggle between French and English civilization for primacy in the world. In our own country, the political birth of which dates from the triumph of England in that mighty struggle, the element of plasticity in man's nature is more thoroughly heeded, more fully taken account of, than in any other community known to history; and herein lies the chief potency of our promise for the future. We have come to the point where we are beginning to see that we may safely depart from unreasoning routine, and, with perfect freedom of thinking in science and in religion, with new methods of education that shall train our children to think for themselves while they interrogate Nature with a courage and an insight that shall grow ever bolder and keener, we may erelong be able fully to avail ourselves of the fact that we come into the world as little children with undeveloped powers wherein lie latent all the boundless possibilities of a higher and grander Humanity than has yet been seen upon the earth.

October, 1883 . 


\section{XIII}

\section{A UNIVERSE OF MIND-STUFF}

$7 \mathrm{HE}$ author of these two remarkable volumes ${ }^{1}$ died last March in the island

1 of Madeira, at the early age of thirtythree, the victim, apparently, of what is called "overwork," - that is, of work long pursued in utter disregard of the necessary limitations and imperative requirements of the human system. Never, perhaps, has the demon of overwork carried off a more illustrious victim. Never, perhaps, has it been more strikingly shown of how little avail is the mere knowledge of hygiene in insuring obedience to its precepts. No one understood better than Clifford what are popularly known as the laws of health; no one had fathomed more deeply or discussed more lucidly the dependence of the mind upon the body; no one in our time has been better able to apply in the physiological domain the most accurate and definite conceptions of the relations of energy to work. Yet from all I

1 Lectures and Essays. By the late William Kingdon Clifford, F. R. S. Edited by Leslie Stephen and Frederick Pollock. 2 vols. 8 vo. London: Macmillan \& Co. 1879. 


\section{A UNIVERSE OF MIND-STUFF}

have been able to learn regarding Clifford's intellectual life, it would seem to have been at all times carried on with an intensely passionate, irrepressible zeal, as regardless of all physical laws as if the mind were not merely a distinct but an independent entity, unhampered even during the present life by physical conditions.

I cite this singular discrepancy between knowledge and practice on account of its intrinsic interest, not in reproof of the course of a friend whose loss I must ever mourn. Admitting, with Mr. Spencer, that one is morally bound so to treat the body as not "in any way to diminish the fulness or vigour of its vitality," one sees at the same time that, as the world is now constituted, emergencies often arise which subordinate to higher duties the duty of keeping oneself well. To save human life I may jump into a freezing river, though an ice-water bath be not recommended by hygienic advisers. So one sympathizes with the heroic sense of duty which often leads the scholar to toil early and late, and long after weariness has set in, in the performance of work which is expected of him, - though in many cases the work itself may be obscure in fame and the taskmaster thankless and treacherous. For my own part I sympathize keenly, too, with a very different feeling, - with that glorious exuberance of vital energy which in youthful days leads one far on into the night, 


\section{EXCURSIONS OF AN EVOLUTIONIST}

working with a kind of sacred fury to seize and secure the sudden glimpses of the fairyland of scientific truth or literary beauty ere drowsy memory shall let them slip and fade away. I think it very likely that in many such cases a systematic self-repression, in deference to hygienic considerations, might be just enough to clip down the brilliant discoverer or original thinker into a mere scientific or literary prig. The secrets of Nature and of Art are not to be won without struggles; and in the serene regions of philosophic meditation, no less than in the turmoil of practical life, the highest results are often accomplished by those who work with desperate energy quite regardless of self. Generous feelings of this sort have no doubt frequently urged great thinkers, like Clifford, fatally to overtask their physical resources; and such mistakes are peculiarly facilitated by the accommodating disposition of that faithful servant the brain, which in men of highly strung nervous temperament is but too ready to keep at its work without protest, as a thoroughbred horse will run till it drops.

In Clifford's case this prodigious enthusiasm for work, joined with an inherited weakness of constitution, has robbed the world of one of its most valuable lives. But though his life was brief, it was wonderfully rich in achievement no less than in promise. He had discerned more, 


\section{A UNIVERSE OF MIND-STUFF}

and discerned it more clearly, in his score and a half of years than most men discern in fourscore. In pure mathematics he was admitted, at the age of twenty-five, to be one of the first five or six original thinkers of Europe. I say this from hearsay, for my own knowledge of the subject is not sufficient to enable me to comprehend his mathematical achievements or to appreciate their bearing. But the power and acuteness with which he treated questions in physics and in general philosophy were very marvellous, and his suggestiveness was so great as already to have entitled him to a high rank among contemporary philosophers. It was impossible for him to touch upon any subject without throwing some new light upon it, for the mere restatement of an old truth in his powerful and luminous language was sure to invest it with fresh and beautiful significance. His skill in scientific exposition was, accordingly, very remarkable. For taking the most hopelessly complicated and abstruse subjects and making them seem perfectly simple and almost self-evident to ordinary minds, I do not know who could be found to compare with him. This rare power he owed largely to the extreme vividness of his imagination. What he saw "with his mind's eye," he saw as accurately and distinctly as only keen observers see things when they look with the physical eye. This is well illustrated in his 


\section{EXCURSIONS OF AN EVOLUTIONIST}

lecture on "Atoms," and in various passages where he has occasion to allude to the intimate constitution of matter, to solidity, liquidity, quantivalence, and so on. People generally, when they talk about atoms, think only of very little particles, without having in mind anything about their various shapes and modes of behaviour. Even scientific men, who get on well enough by the aid of established formulas, now and then betray a similar barrenness of conception when some novel point comes up for discussion. But Clifford would describe a cluster of atoms with as much minuteness and as much animation as a fashionable lady would display in describing the gorgeous costumes of last night's ball. Take the air of this room, for example, which does not fill up all the space in the room, but is composed of a prodigious number of discrete particles of two sorts, - one sort called molecules of oxygen, the other sort called molecules of nitrogen. "These small molecules," says Clifford, "are not at rest in the room, but are flying about in all directions with a mean velocity of seventeen miles a minute. They do not fly far in one direction; but any particular molecule, after going over an incredibly short distance - the measure of which has been made - meets another, not exactly plump, but a little on one side; so that they behave to one another somewhat in the same way as two 


\section{A UNIVERSE OF MIND-STUFF}

people do who are dancing Sir Roger de Coverley, - they join hands, swing around, and then fly away in different directions. All these molecules are constantly changing the direction of each other's motion; they are flying about with very different velocities, although, as I have said, their mean velocity is about seventeen miles a minute. If the velocities were all marked off on a scale, they would be found distributed about the mean velocity just as shots are distributed about a mark. If a great many shots are fired at a target, the hits will be found thickest at the bull's-eye, and they will gradually diminish as we go away from that, according to a certain law which is called the law of error. It was first stated clearly by Laplace; and it is one of the most remarkable consequences of theory that the molecules of a gas have their velocities distributed among them precisely according to this law of error. In the case of a liquid, it is believed that the state of things is quite different. We said that in the gas the molecules are moved in straight lines, and that it is only during a small portion of their motion that they are deflected by other molecules; but in a liquid we may say that the molecules go about as if they were dancing the grand chain in the Lancers. Every molecule after parting company with one finds another, and so is constantly going about in a curved path, and never 


\section{EXCURSIONS OF AN EVOLUTIONIST}

sent quite clear away from the sphere of action of the surrounding molecules. But, notwithstanding that, all molecules in a liquid are constantly changing their places, and it is for that reason that diffusion takes place in the liquid. ... In the case of a solid, quite a different thing takes place. In a solid every molecule has a place which it keeps; that is to say, it is not at rest any more than a molecule of a liquid or a gas, but it has a certain mean position which it is always vibrating about and keeping fairly near to, and it is kept from losing that position by the action of the surrounding molecules." 1

Such scientific exposition as this is as beautiful as poetry. In reading it one feels how the glory and beauty of Nature are immeasurably enhanced for the philosopher who can thus with inward vision distinctly grasp objects and relations too subtile for the eye of sense in any wise to discern.

This same remarkable lucidity is exhibited by Clifford in the treatment of metaphysical problems. In some respects the most striking discussion in the present volume is contained in the essay on "The Nature of Things-inthemselves," where some of the latest suggestions of anti-materialistic philosophy are very forcibly presented. Starting from the impregnable Berkeleian position that the material

1 Vol. i. p. 194. 


\section{A UNIVERSE OF MIND-STUFF}

world of which I am conscious exists only as an organized series of changes in my consciousness, Clifford introduces a very interesting and suggestive distinction between the objective and the ejective elements in cognition. Our inferences concerning the material world are all inferences concerning either some actual or some potential states of consciousness. When I describe the moon at which I am looking, I am describing merely a plexus of optical sensations with sundry revived states of mind linked by various laws of association with the optical sensations. When I say that the moon existed before I was born, I only mean that if I had been alive a century ago and stood here and looked up as I am now doing, I should have had a similar plexus of optical sensations and revived states of mind to describe. Obviously there is nothing else which I can mean; in any statement which I may make concerning the world of matter, I can refer only to things which either are, or may be, or might have been, objects in my consciousness. But it is quite otherwise when I make statements regarding the existence of minds other than my own. "When I come to the conclusion," says Clifford, "that you are conscious, and that there are objects in your consciousness similar to those in mine, I am not inferring any actual or possible feelings of my own, but your feelings, which are not, and 


\section{EXCURSIONS OF AN EVOLUTIONIST}

cannot by any possibility become, objects in my consciousness." In the very act of inferring that you have feelings like mine, some of which you class as objective, and call the outer world, while others you class as subjective, - in the very act of inferring this I recognize these inferred feelings of yours as something outside of myself, as something which is not a part of myself and never could be. These inferred existences Clifford calls ejects, "things thrown out of my consciousness, to distinguish them from objects, things presented in my consciousness, phenomena." My conception of you is " a rough picture of the whole aggregate of my consciousness, under imagined circumstances like yours;" and this conception - unlike my conception of the moon, or of your face - implies the existence of something that can never in any way become a part of my consciousness. Your face, while I am looking at you, is an object in my consciousness; but your consciousness can never be an object in mine, - it is an eject, something entirely outside of my consciousness. And so, too, your thoughts and feelings, the objects in your mind, are to me ejects.

Now my belief in the existence of ejects affects essentially my conception of objects. As a simple object, the table is but a group of my states of consciousness; but when I speak to you of the table, $I$ infer the existence in you of 


\section{A UNIVERSE OF MIND-STUFF}

a similar group of states of consciousness, and this group is an eject. When I think or speak of the table, I bind up together the individual object as it exists in my mind with an indefinite number of ejects assumed to resemble it; and thus is formed the complex conception which Clifford calls the social object, - that is, the conception of the table as an object in human consciousness in general. There now ensues an ingenious and interesting series of inferences. Before our ancestors had become men, or were endowed with anything like a human consciousness, there is every reason for supposing them to have been gregarious in their habits. They were gregarious primates of high sagacity. But gregarious action, among animals endowed with any sort of consciousness, is plainly impossible unless the individual animal recognizes his fellow's consciousness as similar to or kindred with his own. Above all, the first beginnings of speech necessarily involved a belief in the eject. But now, says Clifford, "if not only this conception of the particular social object, but all those that have been built up out of it, have been formed at the same time with, and under the influence of language, it seems to follow that the belief in the existence of other men's minds like our own, but not part of us, must be inseparably associated with every process whereby discrete impressions are built to- 


\section{EXCURSIONS OF AN EVOLUTIONIST}

gether into an object." To vary the quaint expression of Ferrier, the minimum scibile per se is not exactly ego plus object, but it is ego plus eject. Along with what we call the objective element in every piece of our knowledge there is not only a reference to self, but there is also a subconscious reference to other selves outside of us. "And this sub-conscious reference to supposed ejects," continues Clifford, "is what constitutes the impression of externality in the object, whereby it is described as not-me. At any rate, the formation of the social object supplies an account of this impression of outness, without requiring me to assume any ejects or things outside my consciousness except the minds of other men. Consequently it cannot be argued from the impression of outness that there is anything outside of my consciousness except the minds of other men."

By this beautiful method of presentation, so much fresh light is thrown upon some philosophical truths as to make them appear self-evident. See what havoc it makes, at the outset, with the crude notion of the materialists - a notion supported by loose popular language and loose popular thinking - that changes of consciousness are caused by physical actions on or within the organism. Materialists talk about "ideas" as "originating" in the brain; and people generally have become so far impressed with the no- 


\section{A UNIVERSE OF MIND-STUFF}

tion that mental states are caused by physical actions on the nervous system, that when you begin to explain to them the wonderfully $\mathrm{mi-}$ nute correlations between physical action and brain-action which modern psychology is disclosing, they immediately take fright and think you are "explaining away" the mind altogether. They think that in order to refute materialism it is necessary to deny that associations of ideas occur simultaneously with the passage of waves of molecular motion from one cell to another in the gray surface of the brain. I wonder it never occurs to them that they might more summarily effect their purpose by denying, once for all, that the brain has anything whatever to do with mind, or has any further function than that of a balance wheel or "governor" for regulating the motions of the viscera! But in point of fact their alarm is altogether groundless. Those who have mastered the doctrine of the conservation of energy in its bearings upon the facts of psychology will see, as I demonstrated some years ago in "Cosmic Philosophy," that it is utterly impossible that actions in the nervous system should ever, under any circumstances, stand in the relation of cause to psychical actions going on in the mind. A wave of molecular motion in the brain cannot produce a feeling or a state of consciousness. It can do nothing whatever but set up other waves of molecular motion, 


\section{EXCURSIONS OF AN EVOLUTIONIST}

either in the gray matter of ganglia or in the white matter of nerve-fibres. Whatever goes in any way into the organism as physical force must come out again as physical force, and every phase of every transformation that it may undergo in the mean time must be rigorously accounted for in terms of physical force, or else the law of the conservation of energy will not be satisfied. To introduce consciousness or feeling anywhere in the series, as either caused by or causing actions in the brain or nerves, is " not to state what is untrue, but is to talk nonsense," as Clifford would say. These considerations - which must forever shut out sciolists like Büchner from intruding with their self-satisfied explanations into the great primordial mystery of Nature, the relationship of body and soul - would seem to have been clearly appreciated by Clifford; and he states the point in his psychological language with elegant succinctness. "The word Cause, $\pi \circ \lambda \lambda a \chi \hat{\omega} s \quad \lambda \epsilon \gamma o ́ \mu \epsilon \nu o \nu$ and misleading as it is, having no legitimate place in science or philosophy [Chauncey Wright would have said a hearty Amen to that! ], may yet be of some use in conversation or literature, if it is kept to denote a relation between objective facts, to describe certain parts of the phenomenal order. But only confusion can arise, if it is used to express the relation between certain objective facts in my consciousness and the ejective facts which are 


\section{A UNIVERSE OF MIND-STUTFF}

inferred as corresponding in some way to them and running parallel with them. ... The distinction between eject and object, properly grasped, forbids us to regard the eject, another man's mind, as coming into the world of objects in any way, or as standing in the relation of cause or effect to any changes in that world. I need hardly add that the facts do very strongly lead us to regard our bodies as merely complicated examples of practically universal physical rules, and their motions as determined in the same way as those of the sun and the sea. There is no evidence which amounts to a prima facie case against the dynamical uniformity of $\mathrm{Na}$ ture; and I make no exception in favour of that slykick force which fills existing lunatic asylums and makes private houses into new ones."

The doctrine of evolution, as applied by $\mathrm{Mr}$. Spencer to the study of psychical phenomena, nowhere undertakes to interpret Mind as evolved from Matter, but it shows a wonderfully minute and instructive parallelism between the modes of evolution of the total series of objective facts and the total series of ejective facts. Pushing the analysis, both of physical and of psychical phenomena, to its farthest possible limits with the data now at command, Mr. Spencer has shown how all the phenomena constituting a consciousness are compounded of elementary sub-conscious feelings or "psychical shocks." 


\section{EXCURSIONS OF AN EVOLUTIONIST}

Physical phenomena, likewise, in an ultimate analysis, are resolved into simple pulsations or rhythmical movements of ether-atoms; and the question arises as to the relation between the elementary physical pulsation and the elementary psychical shock. Reasoning most ingeniously from the essential continuity in Nature which the doctrine of evolution supposes, and recognizing the impossibility of deriving the psychical element from the physical, Clifford reaches the conclusion that "every motion of matter is simultaneous with some ejective fact or event which might be part of a consciousness." This simple ejective fact or event may be regarded as a molecule, so to speak, of mind-stuff; and we reach the startling conclusion that " the universe consists entirely of mind-stuff. Some of this is woven into the complex form of human minds containing imperfect representations of the mind-stuff outside them, and of themselves also, as a mirror reflects its own image in another mirror ad infinitum. Such an imperfect representation is called a material universe. It is a picture in a man's mind of the real universe of mind-stuff."

Clifford recognizes that this doctrine seems to have been independently arrived at by many persons, and he instances the statements of Wundt in his " Physiologische Psychologie." The theory harmonizes well with that which I have en306 


\section{A UNIVERSE OF MIND-STUFF}

deavoured to elucidate in the chapter on Matter and Spirit in my "Cosmic Philosophy," though the result was reached by different processes of inference in the two cases. With Clifford's further conclusion, that the complex web of human consciousness cannot survive the disintegration of the organic structure with which we invariably find it associated, I do not agree. It is a conclusion not involved in the premises, and is one which no scientific philosopher, as such, has a right to draw. It necessitates as complete a transgression of the bounds of experience as any theologian is ever called upon to make. Least of all would one expect to see Clifford drawing such a conclusion and announcing it with a tinge of dogmatic emphasis withal, after reading his admirable remarks on Lobatchevski, where he shows how strictly the modern thinker must limit his generalizations to the region covered by experience. Were it not for a trifle too much of what Mr. Spencer would call the "anti-theological bias," Clifford's way of reasoning about the universe would have left little to be desired. November, 1879. 


\section{XIV}

IN MEMORIAM: CHARLES DARWIN

1O-DAY, while all that was mortal of Charles Darwin is borne to its last 1 resting-place in Westminster Abbey, by the side of Sir Isaac Newton, it seems a fitting occasion to utter a few words of tribute to the memory of the beautiful and glorious life that has just passed away from us. Though Mr. Darwin had more than completed his threescore and ten years, and though his life had been rich in achievement and crowned with success such as is but seldom vouchsafed to man, yet the news of his death has none the less impressed us with a sense of sudden and premature bereavement. For on the one hand the time would never have come when those of us who had learned the inestimable worth of such a teacher and friend could have felt ready to part with him; and on the other hand Mr. Darwin was one whom the gods, for love of him, had endowed with perpetual youth, so that his death could never seem otherwise than premature. As Mr. Galton has well said, the period of physical youth - say from the fifteenth to 308 


\section{IN MEMORIAM: CHARLES DARWIN}

the twenty-second year - is, with most men, the only available period for acquiring the intellectual habits and amassing the stores of knowledge that are to form their equipment for the work of a life-time; but in the case of men of the highest order this period is simply a period of seven years, neither more nor less valuable than any other seven years. There is, now and then, a mind - perhaps one in four or five millions - which in early youth thinks the thoughts of mature manhood, and which in old age retains the flexibility, the receptiveness, the keen appetite for new impressions, that are characteristic of the fresh season of youth. Such a mind as this was Mr. Darwin's. To the last he was eager for new facts and suggestions, to the last he held his judgments in readiness for revision; and to this unfailing freshness of spirit was joined a sagacity which, naturally great, had been refined and strengthened by half a century most fruitful in experiences, till it had come to be almost superhuman. When we remember how Alexander von Humboldt began at the age of seventy-five to write his "Kosmos," and how he lived to turn off in his ninetieth year the fifth bulky volume of that prodigiously learned book, - when we remember this, and consider the great scientific value of the monographs which Mr. Darwin has lately been publishing almost every year, we must feel that it is in a 


\section{EXCURSIONS OF AN EVOLUTIONIST}

measure right to speak of his death as premature.

After all, however, no one can fail to recognize in the career of Mr. Darwin the interest that belongs to a complete and well-rounded tale. When the extent of his work is properly estimated, it is not too much to say that among all the great leaders of human thought that have ever lived there are not half a dozen who have achieved so much as he. In an age that has been richer than any preceding age in great scientific names, his name is indisputably the foremost. He has already found his place in the history of science by the side of Aristotle, Descartes, and Newton. And among thinkers of the first order of originality, he has been peculiarly fortunate in having lived to see all the fresh and powerful minds of a new generation adopting his fundamental conceptions, and pursuing their inquiries along the path which he was the first to break.

When Mr. Darwin was born, in 1809 , the name which he inherited was already a famous name. Dr. Erasmus Darwin, the friend of Priestley and Watt, and author of the "Botanic Garden," was deservedly ranked among the most ingenious and original thinkers of the eighteenth century in England. His brother, Robert Waring Darwin, was the author of a work on botany which for many years enjoyed 


\section{IN MEMORIAM : CHARLES DARWIN}

high repute. Of the sons of Erasmus, one, Sir Francis Darwin, was noted as a keen observer of animals ; another, Charles, who died at the age of twenty-one from a dissection wound, had already written a medical essay of such importance as to give his name a place in biographical dictionaries; a third, Robert Waring, who achieved great distinction as a physician, married a daughter of the celebrated Josiah Wedgwood, and became the father of the immortal discoverer who has just been taken away from us. While citing these remarkable instances of inherited ability, it may be of interest to mention also that among the cousins of Mr. Darwin who have become more or less distinguished in our own time are Mr. Hensleigh Wedgwood, the philologist, the late Sir Henry Holland, and Mr. Francis Galton, whose excellent treatise on "Hereditary Genius" is known to every one. Nor can it be irrelevant to add that one of $\mathrm{Mr}$. Darwin's sons has already, through his study of the tides, achieved some remarkable results, which seem likely to give him a high place among the astronomers of the present day.

There is one thing which a man of original scientific or philosophical genius in a rightly ordered world should never be called upon to do. He should never be called upon to " earn a living;" for that is a wretched waste of energy, in which the highest intellectual power is sure 


\section{EXCURSIONS OF AN EVOLUTIONIST}

to suffer serious detriment, and runs the risk of being frittered away into hopeless ruin. Like his great predecessor and ally, Sir Charles Lyell, Mr. Darwin was so favoured by fortune as to be free from this odious necessity. He was able to devote his whole life with a single mind to the pursuit of scientific truth, and to ministering in the most exalted way to the welfare of his fellow-creatures. After taking his Master's degree at Cambridge in I $83 \mathrm{I}$, at the age of twenty-two, an opportunity was offered Mr. Darwin for studying natural history on a grand scale. The Beagle, a ten-gun brig under the command of Captain Fitzroy, was then about to start on a long voyage, "to complete the survey of Patagonia and Tierra del Fuego, ... to survey the shores of Chili, Peru, and of some islands in the Pacific, and to carry a chain of chronometrical measurements round the world." As Captain Fitzroy had expressed a wish to have a naturalist accompany the expedition, Mr. Darwin volunteered his services, which the Lords of the Admiralty readily accepted, - $a$ fact which in itself is sufficient evidence of the reputation for scientific attainments which Mr. Darwin had already gained at that youthful age. This memorable voyage, which lasted five years, was very fruitful in results. The general history of the voyage, with an account of such observations in natural history as seemed likely to interest 


\section{IN MEMORIAM: CHARLES DARWIN}

the ordinary reader, is to be found in the "Journal of Researches" published by Mr. Darwin some three years after his return to England. This book immediately acquired a great popularity, which it has retained to this day, having gone through at least thirteen editions; and it is certainly one of the most fascinating books of travel that was ever written. "The author," said the "Quarterly Review," in December, 1839 , " is a first-rate landscape painter with the pen, and the dreariest solitudes are made to teem with interest." An abridgment of this charming journal, lately published with illustrations, under the title "What Mr. Darwin saw in his Voyage round the World," has become a favourite book for boys and girls.

The scientific results of Mr. Darwin's voyage in the Beagle were so voluminous that it required several years and the assistance of many able hands to record them all. Owen, Hooker, Waterhouse, Berkeley, Bell, and other eminent naturalists took part in the publication of these results, which formed a very important contribution to the zoollogy and botany, and to the palæontology, of the countries visited in the course of the voyage. To this great series of volumes, which appeared between 1840 and 1 846, Mr. Darwin contributed three from his own hand, - the work on "Volcanic Islands," the "Geological Observations on South Amer- 


\section{EXCURSIONS OF AN EVOLUTIONIST}

ica," and the famous essay on "Coral Reefs." In this latter work Mr. Darwin proved that through gradual submergence fringing-reefs are developed into barrier-reefs, and these again into atolls or lagoon-islands; and thus he not only for the first time rendered comprehensible the work of coral-building, but threw a new and wonderful light upon the movements of elevation and of subsidence in all parts of the globe. By thus bringing the work of the corals into its direct relationship with volcanic phenomena, Mr. Darwin succeeded in presenting " a grand and harmonious picture of the movements which the crust of the earth has undergone within a late period;" and the result was undoubtedly one of the most brilliant contributions to geology that has been made since the first publication of the great work of Sir Charles Lyell. In $1851-$ 53 Mr. Darwin published a "Monograph of the Cirripedia," in two volumes octavo, and accompanied this, about the same time, with monographs of the various fossil genera of cirripeds (or barnacle family) in Great Britain. In recognition of his solid and brilliant achievements, Mr. Darwin in 1853 received the royal medal from the Royal Society, and in 1859 the Wollaston medal from the Geological Society. By this time his name had come to be known in all parts of the civilized world, and he was already ranked among the foremost living natu- 


\section{IN MEMORIAM : CHARLES DARWIN}

ralists, so that when, in the year 1859 , the "Origin of Species" was published, it at once attracted universal attention by reason of the eminence of its author. I well remember how, in the first few weeks after the book was published, every one at all instructed in the biological sciences was eager to ascertain the views of so distinguished a naturalist with regard to a question which for several years had agitated the scientific world.

Like the great works which had preceded it, the "Origin of Species" must be regarded as one of the results of the ever memorable voyage of the Beagle. In the course of this voyage Mr. Darwin visited the Galapagos Islands, and was struck by the peculiar relations which the floras and faunas of this archipelago sustained to one another, and to the flora and fauna of the nearest mainland of Ecuador, distant some five hundred miles. These islands are purely volcanic in formation, and have never at any time been joined to the South American continent They possess no batrachians and no mammals, save a mouse, which was no doubt introduced by some ship. The only insects are coleoptera, which possess peculiar facilities for transportation across salt water upon floating logs or branches; and along with these are two or three species of land shells. There are also two snakes, one land tortoise, and four kinds of liz. 


\section{EXCURSIONS OF AN EVOLUTIONIST}

ard; and in striking contrast with all this general extreme paucity of animal forms, there are at least fifty-five species of birds. Now these insects, mollusks, reptiles, and birds are like the insects, mollusks, reptiles, and birds of the western coast of South America, and not like the corresponding animals in other parts of the world. But this is not all; for the Galapagos animals, while very like the animals of Ecuador, Peru, and Chili, are not quite like them. While the families are identical, the differences are always at least specific, sometimes generic, in value. Precisely the same sort of relationship is sustained by the Galapagos flora toward the flora of the mainland. And, to crown all, the differences between forms that are generic when the archipelago as a whole is compared with the continent sink into specific differences when the several islands of the archipelago are compared with one another. Such a group of facts as these leads irresistibly to the conclusion that the specific forms of plants and animals have been originated, not by "special creations," but by " descent with modifications." If species have been separately created, there is of course no reason why the population of such an archipelago should be strictly limited to such organisms as can fly or get floated across the water; nor is there any reason why these organisms should resemble those of the nearest mainland rather than those 


\section{IN MEMORIAM: CHARLES DARWIN}

of any other tropical mainland, such as Africa or India. One might indeed object that organisms have been created in such wise as most completely to harmonize with the physical conditions by which they are surrounded, and that it is to be presumed that the physical conditions of the Galapagos Islands are more like those of Ecuador and Peru than they are like those of any other countries; so that in this way the general similarity between the floras and faunas may be accounted for. But such an explanation is very weak, for it rests upon an assumption which has been proved to be untrue. It is not always true that the organisms in any given part of the world are such as harmonize best with the physical conditions by which they are surrounded. It is approximately true only where the competition among organisms is practically unlimited in protected areas it is not at all true. In Australia and New Zealand, for example, the plants and animals which have been introduced by Europeans are exterminating and supplanting the native plants and animals quite as rapidly as the Englishman is supplanting the native human population of these countries. And to state this fact is only to say, in other words, that the plants and animals of Europe are better adapted to the physical conditions which prevail in Australia and New Zealand than the plants and animals which are indige- 


\section{EXCURSIONS OF AN EVOLUTIONIST}

nous there. A comprehensive survey of the distribution of life all over the globe confirms this conclusion, and shows that by no assumption of a special act of creation can the peculiar features of the Galapagos flora and fauna be explained. The only way in which to account for these features is to suppose that the archipelago has been peopled by migrations from the nearest mainland. This explains why the creatures there are most like the creatures of Ecuador and Peru, and it also explains why the only indigenous animals to be found there are such as could have flown or been blown thither, or such as could have been ferried thither on floating vegetation.

But if all this be true - and to-day no competent naturalist doubts it - a conclusion of vast importance immediately follows. If the Galapagos plants and animals are descended from ancestors that migrated thither from the continent, they have been modified during ages of residence in the islands, until they have come to differ specifically, and in many cases generically, from their collateral relations on the mainland. And this amounts to saying that species are not fixed, but mutable, - that every distinct form of plant and animal was not originally created with its present attributes, but that some forms have arisen from the modification of ancestral forms. 


\section{IN MEMORIAM : CHARLES DARWIN}

In this way, from the study of the inhabitants of a single well-defined area, Mr. Darwin was led into a series of most grand and startling considerations relating to the past history of life upon our globe. The conclusions thus succinctly stated were amply confirmed by a survey of the distribution of organisms all over the earth, and thus was inaugurated the study of zoölogical and botanical geography, - a study which in half a century has reached such magnificent proportions in the great works of Hooker and Wallace, and which owes its wonderful progress mainly to the sagacious impulse communicated at the outset by Mr. Darwin. It has now become well established that in very few cases, if any, have animals and plants originated exactly in the places where we now find them, but that they are almost always the offspring of immigrants; and the study of the ancient migrations of the progenitors of living plants and animals has begun to throw a flood of light upon the history of the changes that have taken place in the physical geography of the earth.

The conception of the origin of species through "descent with modifications" having been thus forcibly suggested to Mr. Darwin by the facts of geographical distribution, it was still further strengthened by a study of the geologi. cal succession of extinct organisms and thei. relations to living organisms in the same areas. 


\section{EXCURSIONS OF AN EVOLUTIONIST}

Such broad facts as the successive appearance of various sloth-like and armadillo-like animals in South America, or of various marsupials and monotremes in Australia, forcibly suggest the descent of the later forms from the earlier ones that lived in the same countries. Of like import is the general fact that in the course of geological succession any given organism is sure to be intermediate in character between those that have preceded and those that have followed it. But still more powerfully suggestive even than this is the fact that, in proportion as we go back in geologic time, we find the characteristics of plants and animals to be less and less distinctly specialized: so that, for example, in the Eocene period, instead of horses and tapirs such as now exist we find an animal something like a tapir and something like a horse; and instead of leopards and wolves and bears we find carnivorous animals, not specialized as of feline or canine or ursine family, but with some points of resemblance to all three, and with some points like opossums and wombats into the bargain. In conformity with this general principle, the arrangement of organisms according to their succession in geologic time would be like the branches and branchlets of a tree, which is the typical form of arrangement where the link that connects the facts arranged is the link of parentage. 


\section{IN MEMORIAM: CHARLES DARWIN}

But just here the facts of geological succession are reinforced, with truly overwhelming conclusiveness, by the great facts of classification in the animal and vegetable kingdoms. This branching tree-like arrangement, which alone correctly represents the relationships of organisms in their geological succession, is at the same time the only possible arrangement by which the likenesses and affinities among existing organisms can be represented with anything like an approach to correctness. The facts of palæontology exactly dovetail in with those of taxonomy, and serve to elucidate and emphasize them. Many eminent naturalists before Cuvier attempted to classify all animals in a linear series, but Cuvier proved once for all that no such arrangement is possible. The only feasible arrangement is that of groups within groups, diverging like the branches and twigs of what we aptly term a "family-tree;" and this fact not only strongly suggests the theory of "descent with modifications," but is indeed utterly incompatible with any other theory.

Further powerful evidence in favour of the same view is furnished by countless familiar facts of morphology and embryology. On the theory of " descent with modifications," it is intelligible that all the classes and orders of the vertebrate sub-kingdom, for example, should be constructed on exactly the same fundamental plan, 


\section{EXCURSIONS OF AN EVOLUTIONIST}

- that the arms of men, the fore-legs of quadrupeds, the paddles of cetacea, the wings of birds, and the pectoral fins of fishes should be structurally identical with one another. It is intelligible that a horse's hoof should be, as it is, made up of toes that have grown together. It is intelligible that every mammalian embryo should begin, as it does, to develop as if it were going to become a fish, circulating its blood through gills and a two-chambered heart, and then, changing its course, should behave as if it were going to become a reptile or bird, and only after long delay should assume the distinctive characteristics of mammality. It is intelligible that many snakes should possess beneath their skin the rudiments of limbs; that sundry insects, which never fly, should have wings firmly fastened down to their sides; and that the embryos of many birds, while developing in the egg, should grow temporary teeth within their little beaks. But it is only on the theory of "descent with modifications" that such facts, which are in no wise exceptional, but common throughout the entire animal kingdom, have any meaning whatever.

Many of these facts had been noticed by eminent naturalists before Mr. Darwin, and their incompatibility with any theory of special creations had also been observed; but it was $\mathrm{Mr}$. Darwin who first marshalled them into one 


\section{IN MEMORIAM: CHARLES DARWIN}

mighty argument, of which the cumulative result was that the phenomena of the organic world are unintelligible from beginning to end save on the theory of "descent with modifications." Had Mr. Darwin done nothing but this, it would have given him a peculiar right to associate his name with the development theory, it would have established that theory on a basis of "convincing probability," and it would have entitled him to a high place in the history of scientific thought in the nineteenth century. But Mr. Darwin did not stop here. Convinced by such considerations as those just presented that the specific characters of plants and animals are not constant, but variable, he sought for some grand all-pervading cause of variation in organisms, and his search was crowned with success. This was the achievement which in his hands raised the development theory from the rank of a brilliant philosophical speculation into the rank of an irrefragable scientific discovery. This was the achievement which gave to mankind a new implement of research and a new insight into the workings of Nature, and it was this which justifies us in placing Mr. Darwin's name beside those of Newton and Descartes.

The method by which Mr. Darwin succeeded in discovering the cause of variation in organisms was the thoroughly scientific method of advancing tentatively from the known to the unknown. 


\section{EXCURSIONS OF AN EVOLUTIONIST}

Are there any instances in which the forms of plants and animals have actually been seen to vary, and, if there are, what seems to have been the principal cause of variation in these instances? The answer is not far to seek. The instances are very numerous indeed in which variations - and very marked ones, too - have been wrought in the characteristics of plants and animals through the agency of man. The phenomena of variation presented by animals and plants under domestication are so numerous and so complex that it would require many volumes to describe them. Dogs, horses, pigs, cattle, sheep, rabbits, pigeons, poultry, silk-moths, cereal and culinary plants, fruits and flowers innumerable, have been reared and bred by man for many long ages, - some of them from time immemorial. These domesticated organisms man has caused to vary, in one direction or another, to suit his natural or artificial needs, or even the mere whim of his fancy. The variations, moreover, which have thus been produced have been neither slight nor unimportant, and have been by no means confined to superficial characteristics. Compare the thorough-bred race-horse with the gigantic London dray-horse on the one hand, and the Shetland pony on the other; or, among pigeons, contrast the pouter with the fantail, the barb, the short-faced tumbler, or the jacobin, all of which are historically known to have 


\section{IN MEMORIAM : CHARLES DARWIN}

descended from one and the same ancestral form. The differences extend throughout the whole bony framework as well as throughout the muscular and nervous systems, and exceed in amount the differences by which naturalists often adjudge species to be distinct. Through what agency has man produced such results as these? He has produced them simply by taking advantage of a slight tendency to variation which exists perpetually in all plants and animals, and which exhibits itself in the simple fact that nowhere do we ever find any two individuals exactly alike. Taking advantage of these individual variations, the breeder simply selects the individuals which best suit his purpose, and breeds them apart by themselves. The qualities for which they are selected are propagated and enhanced through inheritance and renewed selection in each succeeding generation, until by the slow accumulation of small differences a new race is formed. And thus we have peaches and almonds from a common source, grapes to eat and grapes to make wine of, pointer-dogs and mastiffs, and so on throughout the list of cultivated plants and domesticated animals.

These facts about variation under domestication are for the most part well known, and the alleged cause of variation, in selection by man, is not an occult cause, but is a phenomenon perfectly familiar to every one. Starting from this 


\section{EXCURSIONS OF AN EVOLUTIONIST}

point, Mr. Darwin made a very elaborate study of all that farmers, horticulturists, and breeders could impart concerning " artificial selection;" and more especially with regard to pigeons his own observations were so extensive and minute that, when the "Origin of Species" was published, I recollect reading one silly review, in which we were gravely informed that here was a new theory of development, - not by a naturalist, but by a mere pigeon-fancier, and probably worthy of very little consideration!

Such being the wonders which man has wrought within a comparatively short time through "artificial selection" in the breeding of animals and plants, the question next arises whether any selective process like this has been going on through countless ages without the intervention of man. Can it be that there is a "natural selection" of individual variations, whereby new species are produced in just the same way that breeders produce new races of pigeons? There is such a " natural selection" forever going on as one of the inseparable concomitants of organic life; and it was just in the detection of this great truth that the very kernel of Mr. Darwin's stupendous discovery consisted. It was here that the poetic or creative act of genius came into play, just as it did in Newton's discovery, when the fall of the moon was likened to the fall of the apple, and the tangential force 326 


\section{IN MEMORIAM: CHARLES DARWIN}

of the moon to the tangential force of a stone whirled at the end of a string. The case is simple enough, when creative genius has once explained it. So great is the destruction of organic life that out of hundreds of seeds, or spawn, or ova, but one or two ever live to come to maturity and reproduce themselves in offspring. Such is the result of the universal and unrelentng competition between organisms for the means of subsistence. Any creature that lives to reproduce its kind is selected from out of a thousand that perish prematurely, and its selection is evidence of its better adaptation to the conditions amid which it is placed. And so stern and so ubiquitous is the competition that there is no individual variation, however slight or apparently trivial, that is not liable to be seized upon and enhanced if it tend in any way to promote the survival of the species. Thus it is natural selection that at every moment preserves the stability of a species, and keeps it in harmony with its environment, by cutting off all individual variations that oscillate too far on either side of a prescribed mean. The stability of a species depends, therefore, upon the stability of the environment ; and the only condition under which a species could remain unchanged would be, that it should remain forever exposed to the action of changeless groups of circumstances. But this has never been the case with 


\section{EXCURSIONS OF AN EVOLUTIONIST}

any species, and never will be. The habitable surface of the earth has been perpetually changing for a hundred million years, and the relations between the countless groups of organisms that have covered its surface have been perpetually changing in endless degrees of complexity; and in such a world, under the working of natural selection, there can be no such thing as "fixity of species."

Having arrived at these grand conclusions, it became comparatively easy for Mr. Darwin to go on and trace the workings of natural selection in many special instances. In these inquiries, upon which he brought to bear a knowledge of the details of organic life more vast and multifarious than has ever been possessed by any other man, he occupied nearly a quarter of a century before it seemed to him that the time had come for making his discovery known to the world. In I 844, he wrote out a brief sketch of the conclusions which, as he modestly says, " then seemed to me probable;" and this sketch he showed to his friend Hooker, perhaps also to Lyell. But fifteen years more, rich in observation and reflection, passed away, and still the world had heard nothing about the origin of species by means of natural selection. How much longer this silence might have lasted, had not an unforeseen circumstance come in to break it, one cannot say. But no doubt it would 


\section{IN MEMORIAM : CHARLES DARWIN}

have lasted some time longer, for Mr. Darwin did not wish to publish his conclusions until he had given due attention to every fact and every argument which might in any way bear upon them; and it is quite evident that when he wrote the "Origin of Species" he did not realize either the wonderful maturity which his argument had attained, or the overwhelming cogency with which he was then actually presenting it to the world. It was very characteristic of $\mathrm{Mr}$. Darwin - into the fibre of whose mind there entered not the smallest shred of egotism or of the pride of knowledge - to make so many allowances for the inevitable incompleteness of his work, when judged by that standard of ideal perfection which he alone among men was able to apply to it, as to have rendered himself incapable for the time being of appreciating its real magnitude. In writing the "Origin of Species," he regarded the book as merely a preliminary outline of his theory, which would serve to prevent his being forestalled by any one else in the announcement of it, and he made frequent allusions to the larger and more elaborate treatise in which he intended presently to follow up the exposition and to reinforce the argument. When I first met Mr. Darwin in London, in 1873 , he told me that he was surprised at the great fame which his book instantly won, and at the quickness with which it carried conviction to the 


\section{EXCURSIONS OF AN EVOLUTIONIST}

minds of all the men on whose opinions he set the most value. The success of his theory was, indeed, wonderfully rapid and complete. To understand him was to agree with him, and before ten years more had passed by, so many able men had become expounders and illustrators of the theory of natural selection that - as he told me - it seemed no longer so necessary as it had once seemed for him to write the larger and more elaborate treatise. The learned work on the "Variation of Animals and Plants under Domestication," which appeared in 1868 in two octavo volumes, formed the first instalment of this long-projected treatise. The second part was to have treated of the variation of animals and plants through natural selection; and a third part would have dealt at length with the phenomena of morphology, of classification, and of distribution in space and time. But these second and third parts were never published.

I alluded, just now, to the " unforeseen circumstance" which led Mr. Darwin in 1859 to break his long silence, and to write and publish the "Origin of Species." This circumstance served, no less than the extraordinary success of his book, to show how ripe the minds of men had become for entertaining such views as those which Mr. Darwin propounded. In $185^{8} \mathrm{Mr}$. Wallace, who was then engaged in studying the natural history of the Malay Archipelago, sent to 


\section{IN MEMORIAM : CHARLES DARWIN}

Mr. Darwin (as to the man most likely to understand him) a paper, in which he sketched the outlines of a theory identical with that upon which Mr. Darwin had so long been at work. The same sequence of observed facts and inferences that had led Mr. Darwin to the discovery of natural selection and its consequences had led Mr. Wallace to the very threshold of the same discovery; but in Mr. Wallace's mind the theory had by no means been wrought out to the same degree of completeness to which it had been wrought in the mind of Mr. Darwin. In the preface to his charming book on "Natural Selection," Mr. Wallace, with rare modesty and candour, acknowledges that, whatever value his speculations may have had, they have been utterly surpassed in richness and cogency of proof by those of Mr. Darwin. This is no doubt true, and Mr. Wallace has done such good work in further illustration of the theory that he can well afford to rest content with the second place in the first announcement of it.

The coincidence, however, between Mr. Wallace's conclusions and those of Mr. Darwin was very remarkable. But, after all, coincidences of this sort have not been uncommon in the history of scientific inquiry. Nor is it all surprising that they should occur now and then, when we remember that a great and pregnant discovery must always be concerned with some question 
which many of the foremost minds in the world are busy in thinking about. It was so with the discovery of the differential calculus, and again with the discovery of the planet Neptune. It was so with the interpretation of the Egyptian hieroglyphics, and with the establishment of the undulatory theory of light. It was so, to a considerable extent, with the introduction of the new chemistry, with the discovery of the mechanical equivalent of heat, and the whole doctrine of the correlation of forces. It was so with the invention of the electric telegraph and with the discovery of spectrum analysis. And it is not at all strange that it should have been so with the doctrine of the origin of species through natural selection. The belief that all species have originated through derivation from other species, and not through special creation, had been held by part of the scientific world ever since the time of Mr. Darwin's grandfather, who was one of its earliest and most eminent advocates. Even those naturalists who did not hold this belief can hardly be said to have held any antagonistic belief, inasmuch as the so-called "doctrine of special creations" is not a positive doctrine at all, but a mere confession of ignorance, and was so regarded by scientific naturalists, such as Owen, for example, before 1859 . The truth is that before the publication of the "Origin of Species" there was no opinion what- 


\section{IN MEMORIAM: CHARLES DARWIN}

ever current respecting the subject that deserved to be called a scientific hypothesis. That the more complex forms of life must have come into existence through some process of development from simpler forms was no doubt the only sensible and rational view to take of the subject; but in a vague and general opinion of this sort there is nothing that is properly scientific. A scientific hypothesis must connect the phenomena with which it deals by alleging a "true cause;" and before I 859 no one had suggested a "true cause" for the origination of new species, although the problem was one over which every philosophical naturalist had puzzled since the beginning of the century. This explains why Mr. Darwin's success was so rapid and complete, and it also explains why he came so near being anticipated. His long delay, however, in bringing forward his theory had one good result. The work was so thoroughly done that, although Darwinism has now for twenty-three years been one of the chief subjects of popular discussion in all the civilized countries of the world, no one as yet seems to have discovered any argument against the theory of natural selection which Mr. Darwin had not himself already foreseen and considered in the first edition of the "Origin of Species."

After an interval of twelve years Mr. Darwin followed up the first announcement of his general theory with his treatise on the "Descent of 


\section{EXCURSIONS OF AN EVOLUTIONIST}

Man," a book which deals with a subject in one respect even more difficult than the origin of species. In his earlier book Mr. Darwin, with masterly skill, brought together huge masses of facts, and showed their bearings upon a few general propositions relating to the whole organic world. In the "Descent of Man" the problem was different. Propositions of great generality, such as had been established in the "Origin of Species," served here as fundamental principles ; but they had to be supplemented by a consideration of the enormously complex and heterogeneous circumstances which attended the origination of a particular genus. It is enough to say that in the treatment of this arduous problem Mr. Darwin showed no less acuteness and grasp than had been displayed in his earlier work.

In connection with this problem of the origin of the human race, Mr. Darwin announced the results of his extensive researches into the subject of sexual selection in the animal kingdom. Some time before this, in his treatise on the "Fertilization of Orchids," published in 1862, he had called attention to the interdependence between the insect world and the world of flowers. Further research in this direction has made it clear that the beautiful colours and sweet odours of flowers are due to selection on the part of insects. The bright colours and delicious perfumes attract insects, who come to sip 


\section{IN MEMORIAM : CHARLES DARWIN}

the nectar, and carry away on their backs the pollen with which to fertilize the next plant they visit. Thus the fairest and sweetest flowers are continually selected to perpetuate their race, and thus have insects and flowering plants been developed in close correlation with one another.

It was Mr. Darwin's good fortune to live long enough to see his theory not only adopted by all competent naturalists, but demonstrated by crucial evidence in the case of at least one genus. The researches of Professor Marsh into the palæontology of the horse have established beyond question the descent of the genus equus from a five-toed mammal not larger than a pig, and somewhat resembling a tapir. All the " missing links" in this case have been found; and thus the primitive barbaric hypothesis of "special creations" may be said to have disappeared forever from the field of natural history. It has taken its place by the side of the Ptolemaic astronomy and the dreams of the alchemists.

Mr. Darwin's latest books belong to a period in which, having lived to witness the complete success of his great work, he has employed his time in recording the results of his researches on many subsidiary points, of no little interest and importance. The treatises on the Expression of the Emotions in Man and Animals, on the Movements and Habits of Climbing Plants, 


\section{EXCURSIONS OF AN EVOLUTIONIST}

on Insectivorous Plants, on Cross and Self Fertilization, on the Different Forms of Flowers, and on the Formation of Vegetable Mould through the Action of Worms, should be read as models of sound scientific method by every one who cares to learn what scientific method is. They may be counted, too, among the most entertaining books of science that have ever been written; and the points that have been established in them, taken in connection with Mr. Darwin's previous works, make up an aggregate of scientific achievement such as has rarely been equalled.

It is fitting that in the great Abbey, where rest the ashes of England's noblest heroes, the place of the discoverer of natural selection should be near that of Sir Isaac Newton. Since the publication of the immortal "Principia," no single scientific book has so widened the mental horizon of mankind as the "Origin of Species." Mr. Darwin, like Newton, was a very young man when his great discovery suggested itself to him. Like Newton, he waited many years before publishing it to the world. Like Newton, he lived to see it become part and parcel of the mental equipment of all men of science. The theological objection urged against the Newtonian theory by Leibnitz, that it substituted the action of natural causes for the immediate action of the Deity, was also urged against 


\section{IN MEMORIAM: CHARLES DARWIN}

the Darwinian theory by Agassiz; and the same objection will doubtless continue to be urged against scientific explanations of natural phenomena so long as there are men who fail to comprehend the profoundly theistic and religious truth that the action of natural causes is in itself the immediate action of the Deity. It is interesting, however, to see that, as theologians are no longer frightened by the doctrine of gravitation, so they are already beginning to outgrow their dread of the doctrine of natural selection. On the Sunday following $\mathrm{Mr}$. Darwin's death, Canon Liddon, at St. Paul's Cathedral, and Canons Barry and Prothero, at Westminster Abbey, agreed in referring to the Darwinian theory as " not necessarily hostile to the fundamental truths of religion." The effect of Mr. Darwin's work has been, however, to remodel the theological conceptions of the origin and destiny of man which were current in former times. In this respect it has wrought a revolution as great as that which Copernicus inaugurated and Newton completed, and of very much the same kind. Again has man been rudely unseated from his imaginary throne in the centre of the universe, but only that he may learn to see in the universe and in human life a richer and deeper meaning than he had before suspected. Truly, he who unfolds to us the way in which God works through the world 


\section{EXCURSIONS OF AN EVOLUTIONIST}

of phenomena may well be called the best of religious teachers. In the study of the organic world, no less than in the study of the starry heavens, is it true that " day unto day uttereth speech, and night unto night showeth knowledge."

April, $\times 882$. 
INDEX 



\section{INDEX}

A bozigines of America formerly thought to be Mongols or ten tribes of Israel, 133.

Acacias, Miocene, 22.

Adapis, 18 ; mistaken by Cuvier for an anoplotherium, 18.

Fons, geological, relative duration of, $4,5,7$; division of the ages into ten, 8 ; actual duration of one of the, 8, 10.

Afghanistan known as Ariana in classical antiquity, 74 .

Africa, strata of, not yet explored geologically, 25 .

Agassiz, Louis, on glacial epoch, 58. Ahriman, and Aryana Vaëjo, 68 ; and Hapta Hendu, 71.

Ahura-Mazda, his creation of the sixteen countries, 68 ; worship of, 70,73 ; leads his followers to Bombay, 70.

Akkadian empire, 43.

Albania, brigandage in, 208.

Albanian language as Hellenic, 85 .

Albert of Brandenburg, catechism of, 87.

Albigensians, their puritanism, 241. Ale probably an Old Aryan word, 127.

Alleghanies and denudation, 12.

Allen, Grant, on history of nations as affected by their geographical positions, 168, 169; and Spencerian evolutionists, 170.

Allen, J. H., Christian History in its three Great Periods, 237.

Alps, and geological denudation, 12 ; Eocene, 16; Miocene, 21; in glaial epoch, 30.
Altaic languages, spoken by nomadic tribes of northern Asia, 89; comprise Finnish, Hungarian, and Turkish, 138.

American civilization, $29 \mathrm{I}$.

Ancestor-worship, 229.

Anchitherium, Eocene ancestor of the horse, 18, 22.

Animals, migration of European, in Pleistocene age, 32 ; domestic, harbingers of civilization, 41 ; first domesticated in Central Asia, 42 ; physical and mental faculties established before birth in lower, 283 ; mental flexibility in lower, 284 ; progression of mental faculties in lower, 284.

Anoplotheria, 18.

Anramainyus, and Aryana Vaëjo, 68 ; and Hapta Hendu, 71 .

Antarctic continent, elevation of, 62, 63.

Antelopes, Eocene ancestor of, 18 ; Miocene ancestor of, 22.

Apennines in Eocene age, 16.

Apes, 18 ; Miocene, 23; anthropoid, 23 ; as ancestors of man, 66 ; intelligence of the higher, 286.

Aphelion, earth's, 49, $5 \mathrm{I}$.

Aquinas, Thomas, 260.

Arabian civilization before and after Mohammed, Outlines of Cosmic $P$ hilosophy on, 170,171 ; Buckle's theory in regard to, 171 .

Arabic words in Persian, 100.

Arabs, conquer Iberians, 44 ; complexion of, 93 ; related to Jews and Syrians, 146. 


\section{INDEX}

Aral, sea of, in Pliocene age, 26 ; possibly known to the Aryans, 129.

Arctic circle in Eocene and Miocene periods, 63 .

Aria probably not connected with Aryan, 80.

Ariovistus, root of, probably not Arya, 80.

Aristotle, Charles Darwin ranked with, 310.

Arkwright, Sir Richard, and social conditions, $187,188$.

Armada, Spanish, and heretics in Spain, 231.

Armenia once supposed to be cradle of human race, 134.

Armenian language, added to IndoEuropean group, 80 ; a division of Aryan speech, 83 .

Arnold, Matthew, on an Eternal Power, 272.

Arrival of Man in Europe, The, 3367.

Art, rudimentary beginnings of, 185 .

Arya, in Persian proper names, 76 ; not the root of Aria, Arii, and Erin, 80.

Aryan, applied to Indo-Persian area, 74 ; derivation of the word, 75 ; root of the word in Persian proper names, 76 ; applied to Indo-European area, $76,8 \mathrm{x}$; never the name of a European people, 80.

Aryan Forefathers, Our, 68-96.

Aryan language, discovery of, 7882,97 ; eight principal divisions of, 82 ; what its extent implies, $9 \mathrm{I}$; consonant-changes in, $\mathrm{IO}_{3}-$ 108; vowel-changes in, 108 ; words for month in, 109, 137 ; legends in, $\mathrm{II}_{3}$; words for house in, 114,115 ; words for village in, 115 ; words for tozen in, 116 ; words for woll in, 117 ; words for roof in, I17; words for door in, 117,118 ; words for windoro in, 118 ; words for corv and bull in, 119, 120; words for money in, 121 ; words for horse in, $\mathbf{1 2 2}$, 125 ; words for cat in, 125, 126; words for mouse in, 126; words for fly in, 126; words for bee in, 127; words for intoxicating drinks in, 127; words for sea in, 128, 129 ; its vocabulary unrelated to the Semitic, 135; its inflection and syntax unrelated to Semitic, 136 ; dispersion of, 148 .

Aryana of the present day, 82 ; area of, in the Old World, 87 ; nonAryan languages in, 87 .

Aryana Vaëjo, creation of, by Ahura-Mazda, 68 ; in the Vendidad, 68 ; in the Minokhired, 73 ; located near the sources of the Oxus and Jaxartes, 75 ; the home of the Aryan race, 75, 81, 95 .

Aryans, their invasion of Europe, $45,65,93$; physical characteristics of, 45 ; intermingling of Iberians and, 46 ; separation of Indo-Persians and Europeans from, 73 ; the name of ancient Persians and Hindus, 73 ; Medes called, 74; Aryana Vaejo in central Asia the horne of, 75 ; as the people who speak the Aryan language, 89,91 ; as an ethnological term, 89, 95 ; the light complexion of, in Indo-Europeans, 93 , 94 ; prehistoric civilization of, reconstructed by means of language, $113-129,147$; political organization of, extremely simple, 130 ; early heroes of, unknown, 185 ; compared with Iroquois Indians, 203. See Indo-Europeans and Old Aryan.

Asia, northern extent in Pliocene age, 25 ; separated from Europe in Tertiary period, 25 ; repeatedly joined to North America, 133.

Asses, learned, 286.

Assyrian language closely related to Hebrew and Syriac, 146, 147. Asturias, language of the, 88 .

Athanasians, 237. 


\section{INDEX}

Atlantic ridge, in Cretaceous period, 16 ; in Miocene age, 21; in Pliocene age, 26, 33 .

Atlantosaurus, discovery of, 6 .

Atoms, motion of, 254 ; Clifford's description of, 296.

Australia, as Aryan, 82 ; foreign plants and animals supplanting the native, 317 ; appearance of marsupials and monotremes in, 320 .

Automatism of repeated impressions, $28 \mathrm{I}-283$.

Auvergne, hippopotamus appears in Pliocene strata of, 27 ; mountains of, in Ice age, 30 .

Avare in European words, 81.

Average, the, in species, $15^{8-161}$; in man's mental capacity, $15^{8-}$ I6r.

Ayra, applied in Sanskrit to cultivators of the soil, 75 ; root of Persian proper names, 76 .

Azara, Felix de, on the language of South American Indians, 156.

Baboons, Miocene, 23.

Badger in the Recent period, $4 \mathrm{I}$.

Bagehot, Walter, his " golden little book," 168 ; on conditions of progress, 170.

Bakhdhi, creation of, by AhuraMazda, 69.

Baktria, creation of, by AhuraMazda, 69; Zendavesta written in dialect of, 69 .

Baltic Sea, in Tertiary period, 25 ; in glacial epochs, 30 .

Bamboos in Pliocene age, 26.

Bask language as an aboriginal language in Europe, 88.

Bask people, complexion of, 93 .

Batrachians, earliest, 7.

Bavaria in Silurian age, 14.

Beagle, the voyage of the, 312 ; scientific results of the voyage, 312-315.

Bears, Pliocene, 27; Pleistocene, 29, $4 \mathrm{I}$; cave, $3 \mathrm{I}, 4 \mathrm{I}$; Recent, 4I ; intelligence of, developed in infancy, 285 ; teachable, 286 ; representative of, in Eocene period, 320.

Bee, Aryan words for, 127.

Beer, doubtful if an Old Aryan word, I27.

Belisarius and his environment, 187.

Bell, Sir Charles, assisted in publication of results of voyage of Beagle, 313.

Berecynthian Mother, adoption of the worship of, 239.

Berkeley, J. M., assisted in publication of results of voyage of Beagle, 313.

Berwick, meaning of the word, 116.

Bignonias, Miocene, 22.

Bigotry co-existing with elevation of character, 194.

Biography, how far useful in sociology, $175-178$.

Birds, earliest, 6,7 ; teeth in embryonic, 322.

Bison, Pleistocene, 29; in Yorkshire, $3 x$.

Black Sea in Tertiary period, 26.

Bleda and the Moriscoes, 222.

Boar, wild, Pleistocene, 29; Recent, 4I.

Bogomilians, their puritanism, $24 \mathrm{I}$.

Bohemia, in Silurian age, 14; in Cretaceous period, 16.

Bohemian language as branch of Slavonic speech, 87.

Bokhara, Tartaric language of, 89 .

Bollandists and the Inquisition, I9I.

Bopp, Franz, his discoveries in comparative philology, 80, 122.

Borromeo, Carlo, Saint, and persecution, 194.

Bowditch, Nathaniel, his translation of Mécanique Céleste, 282.

Brain, feeling and molecular motion in the, 302-306.

Brasseur de Bourbourg, C. E., on migrations, 134.

Breton language, 85 .

Brigandage, extinct in civilized communities, 208. 


\section{INDEX}

British Isles, in Silurian age, 14; in Eocene, 16,17 ; in Miocene, $21 ;$ in Pliocene, 26 ; in glacial epoch, 30 ; in Pleistocene, 33 ; in Recent, 40.

British people, complexion of, 94 .

Brittany, dialect of, as Kymric, 85 . Bronze age, the, 45 .

Brother, derivation of, 103 .

Buckle, H. T., on changes in Arabian civilization before and after Mohammed, 171 ; on intellectual and moral progress in civilization, I93; on causes of persecution, 194-196; on Scotch divines, I97; on expulsion of the Moors from Spain, 222.

Büchner, F. K. C. L., and tendency of modern thought, 247 ; materialism as held by, 253 .

Bulgarian, Old, as branch of Slavonic speech, 87.

Bull, Aryan words for, 120.

Bunsen, C. K. J., Baron, on creation of the sixteen countries by Ahura-Mazda, 70.

Caballus, in Latin, 124.

Cabul, known as Ariana in classical antiquity, 74.

Cresar, Julius, Froude's life of, and Mommsen's, compared, 182 .

California, antiquity of man in, 28 .

Calvin, John, and persecution, 194 ; and essential truths of religion, 273.

Cambrian epoch, records of life in, $4,7$.

Camel, Eocene representative of, I9.

Camphor-trees, Miocene, 22.

Caraffa, G. P. (Paul IV.), and persecution, 194.

Carboniferous epoch, 5, 7 ; physical contour of Europe in, 15.

Carlyle, Thomas, his great-man method of dealing with history commented upon by Spencer, $173^{-175}$; on God in the universe, 275 .
Carnivora, Eocene, I9; reachd their highest point in Miocene age, 22.

Carpathian mountains in Eocene age, I6.

Caspian Sea, in Tertiary period, 26 ; possibly known to the Aryans, 129.

Cat, Aryan words for, 125, 126 ; not domesticated by the Greeks and Romans, 126.

Catholic Church in the future, 263. Caucasus, aboriginal dialects in, 88 ; languages of, belong to the FinnoTataric family, 150 .

Caucasus mountains in Eocene age, 16.

Cause, 304.

Cave-men, advent of, 34,47 ; contemporary with the woolly rhinoceros and mammoth, 36 ; where found, 37 ; their mode of life, 37 ; their drawings and carvings of animals, 38,185 ; probably identical with Eskimos, 39, 47 ; antiquity of, 65 ; gleams of divine intelligence in, 66 .

Celebes, languages of, I 56 .

Cervantes Saavedra, M. de, and expulsion of the Moriscoes, 223.

Chalk, Huxley on, I 5 .

Chamois, Pleistocene, 29.

Changes in communities, as due to accumulated influences of individvals, I64, I65; Outlines of Cosmic Philosophy on, I70-172; influence of environment in, 166 , 167 ; as due to the cumulative effect of individual actions in relation to environing conditions, 167 ; Bagehot on, 168; Grant Allen on, 168.

Chemistry, the new, introduction of, 332.

Chert implements of the river-drift men, 35 .

Chili, its flora and fauna compared with those of the Galapagos Is lands, 316. 


\section{INDEX}

Chimpanzee, 25 ; as the forefather of man, 287.

Chinese language, Aryan names in, 120; how related to the other Mongolian languages, 152-154

Chinese people, complexion of, 93 ; members of the Mongolian race, $15 \mathrm{I}$.

Christianity, and recognition of the individual, 235,243 ; its permanence consists in making right conduct from pure motives the condition of salvation, 236 ; and the church militant, 236 ; became paganized in Christianizing the pagan world, 239.

Christmas, adoption of, 239 .

Church militant, organization of, 236 ; its appeal to feeling of corporate responsibility, 238,239 , $24 I$; its task of civilizing the barbaric world, $23^{8}$; partly paganized, 239 ; persecutions by, in the thirteenth century, 240; and Puritanism, 24 I.

Cinnamon-trees, Miocene, 22 ; Pliocene, 27.

Cirripedia, Darwin's monographs on, 314.

Civets, Miocene, 22.

Civilization, industrial, 185-190. See Industrial arts.

Clan stage of social life, its idea of corporate responsibility, 217,227 ; development of, from the family, 227 ; military and ecclesiastical discipline in, 228 ; ancestor-worship in, 229.

Clarendon, meaning of the word, 116.

Classification of species according to genetic kinship, 321; proves Darwinian theory, 32x.

Clifford, W. K., Lectures and Essays, 292; his death from overwork, 292; his achievements, 294; on motions of molecules, 296-298; on objects and ejects, $300-302$; on consciousness and molecular motion, 302-306; his anti-theological bias, 307 .

Climate of Europe, in Eocene age 17, 30,60 ; in Miocene, 21, 60 ; in Pliocene, 26, 30 ; in Pleistocene, 29-33, 60 .

Club-mosses in Carboniferous epoch, $5,15$.

Coal-bed of Eurgope, 15.

Cockney misuse of $h, 102$.

Codfish, instinct of, $282,283$.

Coenopithecus, 18.

Cognition, ejective and objective, 299.

Coincident discoveries, 331, 332.

Coleoptera in the Galapagos Islands, 315.

Colours of flowers, 334 .

Columbus, Christopher, and social conditions, 187 .

Comfort, physical, within reach of all, 209; growth of the taste for, 210.

Commodus, Emperor, and persecution, 194 .

Comparative method of study, rise of, 77 ; in study of the Aryan race, 96 .

Competition between organirm8, 327 . Complexions of Indo-European peoples, 92 ; in reference to the successive Aryan invasions, 93.

Comte, Auguste, and influence of individuals on history, 172; on tendency of modern thought, 247 ; his use of the word metaphysical, 250; and unity of belief, 264.

Conifers, in Miocene age, 21.

Connecticut Valley, Triassic rocks of, 6 .

Consciousness, always associated with matter in our experience, 253 , 254 ; and molecular motion in the brain, 255, 256, 302-306; and matter, incommensurable, 257 ; objects and ejects in, $300-$ 302 ; as a group of "psychical shocks," 305. 


\section{INDEX}

Consonant-changes in Aryan languages, $103-108$.

Continents, their position practically the same throughout the ages, 13 ; change in superficial contour of, 14.

Contour of Europe, in Silurian age, 14 ; in Carboniferous, Triassic, Juriassic, and Cretaceous, 15 ; in Eocene, 16 ; in Miocene, 20 ; in Pliocene, 26; in Pleistocene, 29, 33 ; in Glacial period, $3 \circ, 56$, $5^{8}$; in Recent period, 40.

Contract and status, 233 .

Cook, Captain James, numerals in the language of Tahiti at the time of, 156 .

Coral-reefs, Darwin on, 314.

Comwall, Kymric dialect formerly spoken in, 85 .

Corporate responsibility, in the tribal system, $217,227-230,243,261$, 290 ; feeling of, pervaded the life of ancient society, 218,226 , $26 \mathrm{I}$; as the main cause of persecution, $219,230-232,261$; at the root of Spanish persecution, 231 ; and the persecutions of Mary Tudor, 23I ; conditions which fostered it, overthrown by establishment of the Roman Empire, $233,243,290$; overthrown by Christianity, 235, 243 ; assumption of, by the church, 238 , 239, 241.

Correlation of forces, 254; and molecular motion, 255 ; simultaneous discoveries in, 332.

Coulanges, N. D. F. de, works of, 176.

Cow, Aryan words for, 119, 120 ; prominent in early Aryan thought, 121 ; used as money, 121; maternal instinct of the, 288 .

Cranes, Miocene, 22.

Creeds, religious, the destruction of present, $247,249$.

Cretaceous epoch, trees in, 6 ; physical contour of Europe in, 15.
Croatian a branch of Slavonic speech, 87.

Croll, James, on our comprehension of a million of years, $\mathrm{ro}$; his Climate and Time, 12 ; on position of the great oceans, 14 ; astronomical interpretation of glaciation of northern hemisphere, 48-65.

Cruelty, connected with primitive warfare, 202 ; in persecutions, 204 ; diminution of, due to the widening of human sympathies, 206; diminished by industrialism, 207 ; replaced by humane feelings, 207, 208.

Cruelty to Animals, Society for the Prevention of, 208.

Crusades and persecution in southern France, 240.

Crustaceans, earliest, 5, 7 .

Cuneiform inscriptions, of Darius, 74 ; Persian, 83.

Cuvier, G. C. L. F. D., Baron, and Eocene mammals, 18 ; and the comparative method of study, 77 . Cycads, Miocene, 22.

Daëvas of Ahriman, 68.

Dalton, J. C., and the believers in phlogiston, 176.

Danube, valley of, in the Miocene age, 20 ; as a Keltic name, 84.

Darius Hystaspes, and the Zendavesta, 69; declares himself an Aryan, 74.

Darwin, Charles, author of a medical essay, 311 .

Darwin, Charles R., on our conception of a million of years, 10 ; his death premature, 308,309 ; his freshness of spirit and sagacity, 308,309 ; achievements of, 310 ; his family name already famous at the time of his birth in 1809 , 310 ; his ancestors, 310, 311; his relatives and sons, 311 ; relieved from the necessity of earning a living, 312 ; receives Master's degree and embarks on the 


\section{INDEX}

Beagle, 312 ; scientific results of the voyage on the Beagle, 312315 ; publishes Fournal of Researches, 313 ; publishes Volcanic Islands, Geological Observations on South America, and Coral Reefs, 313, 314 ; publishes Monograph of the Cirripedia, 314 ; publishes Origin of Species, 315,328 ; his study of the flora and fauna of the Galapagos Islands, 31 5-3 9 ; inaugurates the study of zoological and botanical geography, $3 \times 9$; his conception of Descent with Modifications, 319-323; his discovery of the law of natural selection, 323328 ; his plans for a more elaborate work on species, 329 ; the adoption of his theories, 329 , 333,335 ; publishes $V$ ariation of Animals and Plants under Domestication, 330; publishes Descent of Man and Fertilization of Orchids, 333, 334; publishes Expression of the Emotions in Man and Animals, Movements and Habits of Climbing Plants, Insectivorous Plants, Cross and Self Fertilization, Different Forms of Flowers, Formation of Vegetable Mould through the Action of Worms, 335, 336; his work compared with Sir Isaac Newton's, 336 .

Darwin, Erasmus, an ingenious and original thinker, 310 ; author of Botanic Garden, 310.

Darwin, Sir Francis, author of a book on botany, 3 Io ; a keen observer of animals, $3 \mathbf{1 1}$.

Darwin, R. W., father of C. R. Darwin, 3 II.

Darrvinism and other Essays on the meaning of infancy, 227.

Dasyus races of Hindustan, 74.

Davila, G. G., on the expulsion of the Moriscoes, 223.

Davy, Sir Humphry, and believers in phlogiston, 176 .
Dawkins, Boyd, on man and the Eocene age, 20; his Early Man in Britain, 23 ; on river-drift men, 34 ; on cave-men, 39 .

Deer, Eocene ancestor of, 18 ; Miocene ancestor of, 22, Pliocene, 27; Pleistocene, 29, 31 .

Dehra Dhun, meaning of, 116 .

Deinotherium, 22.

Dentreath, Dame Dolly, last speaker of the Cornish dialect of Kymric, 85.

Denudation, geological, rate of, 12.

Descartes, René, C. R. Darwin ranked with, 310.

Descent with modifications, suggested by facts of geographical distribution traced by Darwin in the Galapagos Islands, 319; strengthened by facts of geological succession, 320 ; by genetic classification of species, 321 ; by morphology and embryology, 321.

Destiny of Man, on the meaning of infancy, 279.

Deviations from an average, $15^{8}$; in species, 159,160,162; in mental capacity, 159; law of, inexplicable, 161 .

Devonian epoch, fishes and insects in, 5,7 .

Dialects, the rise of, $141-143,145$; the Parisian and Tuscan, 142, 143 ; the decay of, 143, 145; of savages, 155,156 .

Differential calculus, simultaneous discoveries in, 332 .

Discoverers, the great, belong to modern times, 184, 185; 8ocial conditions and, 185-190.

Dnieper a Keltic name, 84.

Dog, harbinger of civilization, $4 \mathrm{I}$; is teachable, 286 ; domesticated by man, 324 .

Domestication, variation in plants and animals under, 324 .

Dominic, Saint, his biography by Lacordaire, $191 \cdot$ and persecution, 194. 


\section{INDEX}

Don, in European geographical names, 84 ; a Keltic name, 84.

Door, Aryan words for, $117,118$.

Dorians, 45.

Dragons of the prime, 6 .

Drake, Sir Francis, 82.

Dravidian languages, 138 .

Dryopithecus, 23,24 .

Duelling nearly obsolete, 208 .

Dumbarton, meaning of the word, 116.

Dundee, meaning of the word, 116 . Dunkeld, meaning of the word, 116 .

Eagles, Miocene, 22.

Earth, crust of the, how long solidified, 9 ; oscillations of, 13, 314 . Earth's orbit, changes of, the cause of glacial period, 48 ; as affecting our change of seasons, 48 ; periods of high eccentricity of, 50,59 , $6 x, 65 ;$ as affecting the climate of the northern hemisphere, 51 , 55,56 ; as affecting the climate of the southern hemisphere, 53 , 56 ; as the cause of various glacial periods, 60.

Easter, adoption of, 239.

Ecuador, its flora and fauna compared with those of the Galapagos Islands, 31 5-318.

Educability, of the lower animals, 284; of higher mammals, 286.

Edwards, Jonathan, as a materialist, 250.

Effective desire of accumulation and the complication of mental and moral processes, 197-201.

Egyptian hieroglyphics, simultaneous discoveries in, 332.

Ejects or inferred existences, 300302,305 .

Elagabalus and persecution, 194.

Electric telegraph, invention of, 332.

Elephant, first appears in Pliocene age, 27 ; Pleistocene, 29 ; Recent, 41 ; is teachable, 286 .

Elk, in Yorkshire, 31,41 ; Irish, in Recent period, 4I.
Elms, Miocene, 22.

Embryology, facts of, in proof of Darwinian theory, 322.

England, advantage of her social plasticity in her rivalry with France, 291.

English Channel, in the Miocene age, 21 ; in Recent period, 40.

English language, the probable future of, 82,144 ; a branch of Teutonic speech, 86, 100 ; few Keltisms in, 90 ; half made up of Latin words, 90 .

English people, as Aryans, 76; much Keltic blood and few Keltic words among the, 90 ; many Latin words and little Roman blood among the, 90 .

Environment, and geniuses, 162, 186 ; its influence in causing 80cial changes, 166,168 ; Grant Allen on, 169 ; and industrialism, 186-188.

Eocene age, 7 ; beginning of, 10 ; physical contour of Europe in, 16 ; mammals of, 16-20, 28 ; animals less distinctly specialized in, $18,19,28,320$; vegetation of, 18; man did not exist in, 20 ; lemuroids of, are the link between man and horse, 18 ; climate of Europe in, 60.

Eozoōn, Canadian, $4,7$.

Equinoxes, precession of, $5 \circ$.

Ericsson, John, precursors of, 185 .

Erin, etymology of the word, 80.

Error, Laplace's law of, 297.

Eskimos, probably sole survivors of the Cave-men, $4^{\circ}$; allied to the Samoyeds, 151.

Esthonian as a non-Aryan language, 88.

Ethel, as the root of Old English proper names, 76.

Ethics and evolution, 276.

Ethnology, change in our point of view of, in recent years, 133 .

Etruskan possibly an aboriginal language in Europe, 88. 


\section{INDEX}

Etruskans were Iberians, 45.

Etymology, former unscientific character of the study of, 97 ; orderly inference substituted for guesswork in the study of, 99 ; resemblance a treacherous guide in, 104.

Euphrates, 70.

Europe, before the Arrival of Man, 1-32; succession of races in, 46, 92.

Euskarian an aboriginal language in Europe, 88.

Evarts, W. M., at the farewell dinner to Herbert Spencer, 268.

Evolution, theory of, in the philosophy of the present age, 259 ; and essential truths of religion, 274, 277 ; asserts the presence of an Eternal Power in the universe, 274; asserts the principles of right living, 277.

Exclusive salvation, dogma of, and persecution, 195 ; discredited through modern scepticism, 196.

Executions, private, 208.

Explanations after the fact, 169 , 179.

Externality, 302.

Extravagant expenditure, causes of, $199,200$.

Fable of the Sheep and the Horses, Ixo, $1 \times 1$.

Faculties, training of man's, until they work instinctively, 281 .

Family, the, development of the clan from the, 227 ; origin of, due to prolongation of infancy, 227, 288 ; and the beginning of human morality, 289 .

Fan-palms, Miocene, 22.

Father, derivation of, 103.

Fear connected with cruelty, 229.

Feather and pen, 105, 106.

Fee, pecunia and pecus, $12 x$.

Feeling and molecular motion in the brain, 256, 257.

Ferns, arborescent, in Carboniferous epoch, 5 .
Ferrier, J. F., his minimum seibilo per se, 302.

Fick, August, his Vergleichendes Worterbuch der Indogermanischen Sprachen, 113.

Fig-trees, Miocene, 22.

Finality, craving for, 266.

Finland, in Silurian age, 14; in Tertiary period, 26 ; in glacial epochs, 30.

Finnish language, as the language of tribes conquered by Aryans, 88; belongs to the Altaic, Turanian, or Tataric family, 89, 138,149 ; how related to the Turkish, 89,151 .

Finno-Tataric languages, Aryan names in, 120 ; as represented in Europe and Asia, 149, 150.

Finno-Tataric race, apparently allied to the Aryans and Semites, 149, I 51 .

Fire-worshippers, 70.

Fishes, earliest, 5,7 .

Fitzroy, Robert, captain of the Beagle, 312.

Fixity of species, theory of, disproved by flora and fauna of the Galapagos Islands, 318.

Flamingoes, Miocene, 22.

Flint knives found in the valley of the Thames, 31 ; implements of the river-drift men, 35 .

Flints chipped in Miocene age, 24.

Florence, a political and intellectual centre, 142.

Fly, Aryan words for, 126.

Fly-catcher, instinct of, 283 .

Fotal life of a mammal, 322 .

Folkmote, 177.

Footprints in Connecticut sandstone, 6.

Forces, correlation of, 254, 255, 332.

Fox, Arctic, Pleistocene, 29.

France, Eocene primates in, 18 ; flint implements in Miocene strata of, 24 ; human remains in Pliocene strata of, 27; her rivalry with England, 291. 


\section{INDEX}

Freeman, E. A., on history of England in 1066,2 ; his study of Indo-European politics and jurisprudence, 130 ; compared with Macaulay, 176; his scientific spirit, 183 ; a hero-worshipper, 183.

Free-thinking, and eminent men, 245 ; and Unitarians, 246.

French language, as a Latin language, 85,137 ; kinship with the Italian perfectly evident, 148.

French people, related to Spaniards and Italians through Keltic ancestors rather than through Latin dialect, 90 ; character of, injured by persecution, 240 .

Frobisher, Martin, 82.

Froude, J. A., his life of Czesar compared with Mommsen's, 182.

Fruits cultivated by Neolithic men, 42.

Fulton, Robert, precursors of, 185.

Gaelic language a division of Keltic, 84.

Galapagos Islands, their flora and fauna compared with those of the adjacent mainland by Darwin, 315-318.

Galton, Francis, on physical growth, 308, 309; author of Hereditary Genius, 3 II.

Garden, derivation of, 103 .

Gases, molecules of, 297.

Gaudry on Miocene man, 24.

Gaul, Eocene, 16 ; Miocene, 20 ; language of, trampled out by Latin, 84 ; Roman manners of, 90.

Gauls, complexion of, 94 .

Geese, Miocene, 22.

Geikie, Archibald, on position of the great oceans, 14; on Silurian rocks of Europe, 15 ; on geography of eastern Europe in Pliocene age, 26.

Geikie, James, on position of the great oceans, 14 ; on the Atlan- tic ridge, 33 ; on alternations of glacial epochs, 57.

Genesis, Book of, relates only to Semitic race, 134 .

Geniuses, analogy between spontaneous variations and, 158,161 , 162 ; mental, 159 , 160 ; relation of environment to, 162, 186190 ; influence of, on mutations of society, 163 ; Spencer on the causes of the production of, 173.

Geographical distribution, facts of, studied by Darwin in the flora and fanna of the Galapagos Islands, 315-319.

Geography, zoölogical and botanical, the study of, 319 .

Geological epochs, relative duration of, $3,5,6$.

Geological succession, confirms Darwinian theory, 319 ; specialization of mammals in, 320 .

Geology, method of study of, 178 .

German language, found to be of Indo-European group, 79; a branch of Teutonic speech, 86 .

German Ocean, in Silurian age, 14 ; in Miocene age, 21.

Getæ as Goths, 86.

Ghosts, of dead heroes, and poetry, 185 ; of dead chieftains in primitive philosophy, 229.

Glacial epoch, in North America, $30,5^{8}$; in Europe, $30,56,5^{8}$; Croll's astronomical interpretation of, 48-65; date of, calculated, $48,58,65$; causes of, 48-56; Agassiz on, $5^{8}$; coincident with Pleistocene age in Europe and America, 59.

Glacial epochs, $30,57,59$; alternations of, explained, $48-57$; recurrence of, in various periods, 59-6r.

Glaciation of northern hemisphere, 30 ; Croll on, 48-65; caused by changes in the earth's orbit, 48$5 x, 56,58,60$; by earth's stor- 


\section{INDEX}

ing up of ice and snow, 5 r, 6I ; by formation of fog, 52 ; by flow of ocean currents, 53-56, 64 ; in successive periods, 59-61.

Glutton, Pleistocene, 29.

Goat, harbinger of the dawn of civilization, 41 .

God, man's idea of his justice, 206.

Godfrey de Bouillon and social conditions, 187.

Goose, derivation of, 103 .

Gorillas, 25 ; as the forefathers of man, 287.

Gothic language, found to be of Indo-European group, $79 ;$ as a division of Teutonic, 86 ; extinct, save for a portion of Ulfilas's translation of the Bible, 86.

Goths, diffusion of, in the time of Herodotos, 86.

Grains cultivated by Neolithic men, 42.

Grasmere, meaning of the word, 128.

Great men and environment, 185 , 186.

Greek language, similarity between Latin and, 78,85 ; relationship between Latin, Sanskrit, and, 79 ; as Hellenic, 85 ; spoken all over the East at time of Roman conquest, 140.

Greeks, as Aryans, 76; their separation from Italians comparatively recent, 85 ; time of their invasion of Europe, 85 ; little known of their prehistoric career, 85 ; complexion of, 94 ; their feeling of corporate responsibility, 230.

Greenland, in Eocene age, 16 ; in Cretaceous, 16 ; deciduous trees in, 17 ; covered with luxuriant vegetation in Miocene age, 21, 64; climate of, in Pliocene, 26; in Miocene, 64 ; perpetual snows of, 62.

Gregariousness, Clifford on, $30 \mathrm{r}$.

Gregory VII., ecclesiastical reforms of, 170.
Grief outside the circuit of physical causation, 254, 256.

Grimm, Jakob, on ancient Thracians, 86 ; his discoveries in comparative philology, 132.

Grimm's law, illustrations of, 103 , 104.

Grinnell Land, perpetual snows of, 62.

Grote, George, on the dialogues of Plato, 246.

Gulf Stream, 54; course of, 55, 56.

Gutenberg, Johann, and social conditions, 187.

Hâche, the, of the river-drift men, 35.

Hannibal, environment and, 186.

Hapta Hendu of the Zendavesta, 71.

Have, conjugated in Aryan languages, 101.

Heat, carried by Gulf Stream, 55 ; discovery of the mechanical equivalent of, 332.

Hebrew language, unrelated to the languages of Europe, 78, 98, 135 ; once considered the parent of all languages, 135 ; word for six in, 135 ; closely related to Syriac and Assyrian, 146, 147.

Hecla, 21.

Hedgehogs, Miocene, 22.

Hellenic languages, as the fifth grand division of Aryan speech, 85 ; close relationship between Italic and, 85 ; divisions of, 85 .

Hell-fire, doctrine of, part of the theology of an age of cruelty, 205.

Helmholtz, H. L. F., as a genius, 160.

Heredity, the important factor in life of the lower animals, 283 ; its influence modified by mental plasticity acquired by infancy, 286; illustrated in the Darwin family, 310,311 . 


\section{INDEX}

Heresiarchs no longer found among eminent men, 245.

Heresy, on the word becoming obsolete, 266.

Herma, mutilation of the, 218 .

Herodotos, Hellenic language of, 85 .

Heroes of Industry, I 84-I 90.

Herons, Miocene, 22.

Himalayas in glacial epoch, 31 .

Hindus, migration of, from central Asia, 70, 72 ; called Aryans, 73.

Hindustan, Indo-Persians in, 72 ; dialects spoken in, 83 .

Hipparion, Miocene ancestor of the horse, 22 ; still lived in Pliocene age, 27.

Hippopotamus, African, the first species to survive from the Pliocene age to present time, 27, 29.

History, Carlyle's method of dealing with, I75; revolution in the study of, during the nineteenth century, 175, I81; sociology and, 175, 177, 181 ; distinction between study of sociology and that of, $17 g_{-1} 82$.

Holland, Sir Henry, cousin of C. $R$. Darwin, 3 I I.

Holland, Spanish atrocities in, 204.

Honey among the Aryans, 127.

Hooker, Sir J., assisted in publication of results of voyage of Beagle, 31 3 ; scientific achievements of, 319.

Horse, Eocene representative of, I 8 , 19,320 ; the link between man and, 18 ; Pliocene, 27 ; Pleistocene, 29 ; harbinger of civilization, 41; Aryan words for, 122 125 ; is teachable, 286 ; domesticated by man, 324 ; breeding of the, 324.

Horse-tail, the, in Carboniferous age, 5.

House, Aryan words for, II4, II5. Humane feelings favoured by industrialism, 207-209.

Humboldt, F. H. A. von, began his Kosmos at the age of seventy five, $3 \circ 9$.

Hungarian language, brought into Europe by recent intruders, 89 ; whence sprung, 89 ; affinity with Finnish, 89 ; one of the Altaic or Finno-Tataric family of languages, $89, I_{3} 8$, I 50.

Huns, invasion of, drove Teutonic tribes westward, 86.

Hunter, William, burning of, 205.

Huss, John, 103.

Hussites, their puritanism, 241.

Hutton and cockney misuse of $h$, 102.

Huxley, T. H., his lecture On a Piece of Chalk, I5; his Lay Sermons, 16 ; On Some Fixed Points in British Ethnology, 95.

Hyzna, Pliocene ancestor of, 27 ; Pleistocene, 29 ; Recent, 4I.

Hygiene and intellectual work, 293. Hypothesis lies at the foundation of all scientific knowledge, 185.

Iapygian language possibly an aboriginal language in Europe, 88.

Iberian language an aboriginal language in Europe, 88.

Iberian race, diffusion of, in Neolithic period, 44 ; intermingling of Aryan race and, 46, 47 ; antiquity of the time of their invasion of Europe, 65 ; dark complexion of, traced in Indo-Europeans, 93.

Ibex, Pleistocene, 29.

Ice, earth's storing up of, 51, 62 .

Ice age, in Europe, 30 ; in North America, 30. See Glacial period and Glaciation.

Iceland in Eocene age, I6.

Iguanodon, 6.

Imagination, its effect upon conduct, 197.

Improvidence of savages, 198.

India, conquest of, and establishment of Indo-European family of languages, 78, 97 ; non-Aryan tribes in, 88 . 


\section{INDEX}

Indian languages, found to be of Indo-European group, 79; the first grand division of Aryan speech, 83.

Indian Ocean, in Tertiary Period flowed between Europe and Asia into the Arctic Ocean, 25, 63; effect of its waters on the climate of Greenland in Miocene age, 64 .

Indians, North American, formerly thought to be Mongols or ten tribes of Israel, 133 ; indigenous to the continent, 133 .

Indians, South American, language of, 156 .

Individual, the, his rights ignored in primitive society, 217 ; recognition of, under the Roman Empire, 233 ; responsibility of, 233, 235, 241,262 ; recognition of, by Christianity, 235; and religious belief, 266 .

Indo-European group of languages, established by study of Sanskrit, 78 ; idea conceived by Sir William Jones in 1790, 79; maintained by Schlegel in 1808,79 ; maintained by Bopp in 1833,80 ; the name established, 80 ; designated as Aryan language, $80,8 \mathrm{I}$; an exclusive and interrelated group, 98. See Aryan and Old Aryan.

Indo-Germanic, Schlegel's name for Indo-European group, 79.

Indo-Persians, 80.

Indus, the, $70,7 \mathrm{r}$.

Industrial arts, rudimentary beginnings of, $\times 85$; social conditions and, 185 ; political stability of society and, 186 ; extent of commerce and, 187 ; physical science and, 187; humane feelings favoured by, 207.

Infallibility, assumption of, 213, 215.

Infancy, prolongation of, an important factor in man's development, $280,287,289$; development of the nervous system and, 285 ,
287 ; in the lower animals, 285 ; in the orang-outang, 285 ; origin of family life due to, 288 ; man's descent from the highest of animals due to, 289 .

Infanticide in primitive tribal society, 228.

Infidelity, the word becoming obsolete, 266.

Ingersoll, Robert, and corporate responsibility, 219.

Inquisition, the origin of, in the thirteenth century, 240.

Insectivora, Eocene, 19.

Insects, earliest, 5,7 .

Insurance, fire, in illustration of man's tendency to provide for the future, 198 .

Intellect, dawn of, in the Cave-men, 66 ; man's acquisition of, 67 .

Intellectual progress inseparable from moral progress, 197.

Intelligence and moral disposition inseparable, 197, 200.

Inventors, the great, belong to modern times, 184,185 ; environment and early, 185 ; social conditions and, 186-188.

Ionians, 45 .

Iranic languages, the second grand division of Aryan speech, 83 .

Ireland, Arya not the root of the word, 80 ; derivation of the name, 81; Gaelic language in, 85 .

Iroquois tribe an example of primitive society, 203.

Isabella of Castile and persecution, 194.

Isle of Man, Gaelic language still spoken in, 85 .

Italian, a Latin language, 85,137 ; kinship with the French, perfectly evident, 148.

Italians, separation between Greeks and, comparatively recent, 85 ; time of their invasion of Europe, 85 ; little known of their prehistoric career, 85 ; related to the French and Spanish through Kel- 


\section{INDEX}

tic ancestors, 90 ; complexion of, 94.

Italic languages, found to be of IndoEuropean group, 79 ; the fourth grand division of Aryan speech, 85 ; close relationship between Hellenic and, 85 ; divisions of, 85.

Italic races and the tribes of Latium, 90.

Italy, in Miocene age, 20 ; vegetation of, in Pliocene age, 27.

Iver is root of words Ivernia, Irish, and Ireland, 81 .

Ivernia, derivation of, $8 \mathrm{x}$.

Ivies, Miocene, 22.

James, William, his Great Men, Great Thoughts, and the Environment, 158.

Japanese language, Aryan names in, 120; how related to the other Mongolian languages, $152-154$.

Japanese people, complexion of, 93 ; members of the Mongolian race, 151.

Jesus, teachings of, point to individual obligation, 235 .

Jews, related to Arabs and Syrians, 146 ; their feeling of corporate responsibility, 230 .

Jinghis Khan, 150 , 151 .

Jones, Sir William, on relationship between Greek, Latin, and Sanskrit, 79.

Julian, Emperor, and persecution, 194.

Jurassic epoch, giant reptiles in, 6, 7 ; physical contour of Europe in, r5.

Kafirs, complexion of, 93 .

Kawi, the Malay language of Java, full of Sanskrit words, 124.

Keltic blood, but little Keltic speech among the English, 90 .

Keltic geographical names scattered all over Europe, 84. Keltic languages, found to be of Laplace, P. S. de, his Mécanique
Indo-European group, 79, 80 ; a a division of Aryan speech, 83 ; now fast disappearing, 84 ; two groups of, remain in the present day, 84 .

Kelts, their invasion of Europe, 45 ; first to separate from original Aryan tribes, 83,84 ; diffusion of, over Europe under Roman dominion, in Christian era, and in later times, 84 .

Khiva, language of, 89.

Kjarda Dhun, meaning of, 116 .

Knowledge and practice, discrepancy between, 293.

Kuhn, Adalbert, his Beiträge sur vergleichenden Sprachforschung, 111.

Kurdish a division of Aryan speech, 83.

Kymric language a division of Keltic, 85.

Kymry, their invasion of Europe, 45.

Lacordaire, J. B. H., his biography of St. Dominic, 191 ; his Etudes sur la littérature contemporaine, 191.

Lafuente, Modesto, on expulsion of the Moriscoes, 223.

La Mettrie, J. O., principles of materialism as held by, 253.

Language, epithets applying to, used in an ethnological sense, 89 ; not a sure index of race, 89,90 ; original community of, 95 ; former unscientific character of the study of, $97,9^{8}$; true signs of relationship in, 97,98 ; divergence of, 102, 141-143, 145 ; the science of, is historical, 112 ; enables us to reconstruct civilization of prehistoric Aryans, $\mathrm{I}_{3} \mathbf{3}$; no single primeval, $135^{-1} 39$; a universal, probable in the future,

145 ; of savages, changes quickly, 155 . 


\section{INDEX}

Céleste, 282 ; on molecular motion, 297.

Lappish a non-Aryan language, 88. Latin language, similarity between Greek and, brought out by study of Sanskrit, 78 ; relationship between Greek, Sanskrit and, 79, 149; a division of Italic language, 85 ; spread of, over western Europe, $139,14^{\circ}$; as spoken in the provinces, 140; divergence of, into dialects, 141, 142.

Latin race, misuse of the term, $9 \circ$, 92.

Latin tribes, 45 .

Latium, its tribes absorbed in the Italic race, 90.

Laurels, Miocene, 22.

Laurentian epoch, records of life in, 4, 7 .

Lemur, Eocene representative of, 18.

Leopard, Pleistocene, 29; representative of, in Eocene age, 320.

Lessing, G. E., his theory of the relative truth of opinions and religious development, 192.

Lettic languages, as the seventh grand division of Aryan speech, 87 ; divisions of, 87 .

Lettish, as a branch of Lettic language, 87 ; spoken in the Baltic provinces of Russia, 87 .

Leverrier, U. J. J., on changes in earth's orbit, 50 .

Lewes, Mrs. G. H., 200.

Leyden, meaning of the word, 116. Life, antiquity of, on the earth, 8.

Ligurians as Iberians, 45 .

Lindens, Miocene, 22.

Linear classification of animals impracticable, 321 .

Lion, sabre-toothed, larger and more fierce than our lion or tiger, 23 ; the ancestor of our panthers and lynxes, 27 ; extinction of, 31 .

Lions, in Pleistocene age, 29; in Yorkshire, 31 .

Liquids, 297.
Lithuanian found to be of Indo-European group, 80 ; a division of Lettic language, 87 ; spoken in Baltic provinces of Russia, 87 ; strong resemblance to Sanskrit, 87.

Lizards in Galapagos Islands, 315.

Lobatchevski, Clifford on, 307 .

Lollards, their Puritanism, 241.

London, meaning of the word, 116.

Louer, meaning "to hire" and "to praise," 104.

Lugdunum, meaning of the word, I1 6.

Luther, Martin, his revolt against the church's assumption of corporate responsibility, 241, 243, 262 ; his revolt the assertion of individual rights and responsibilities, 241.

Lyell, Sir Charles, relieved from the necessity of earning a living, 312 .

Lynx, Pliocene ancestor of, 27.

Lyons, vegetation about, in the Pliocene age, 27 ; meaning of the word, 116.

Macaulay, T. B., compared with Freeman, 176 .

Machairodus, or sabre-toothed lion, 23.

Madrid, depopulation of, 223.

Magdeburg, atrocities of the imperial armies at, 204.

Magian religion and Mohammedans, 70.

Magnolias in Pliocene age, $2 \%$.

Maine, Sir Henry, his study of IndoEuropean politics and jurisprudence, 130, 132; his method, 176 ; on primitive society, 217.

Mammals, earliest, 5, 7 ; Eocene, 16-20; Eocene, far less highly specialized than those of the present time, $18,19,28,320$; Miocene, 22, 28 ; Pliocene, 27, 31 ; Pleistocene, 29 ; migration of European, in Pleistocene age, 32 ; Recent, $4 \mathrm{I}$.

Mammoth, Pleistocene, 29. 


\section{INDEX}

Man, not found in Eocene age, 18 ; his presence doubtful in Miocene, 23-25; found in Pliocene, in Portugal and California, 28, 32, 66 ; in river-drift, $31,34-36$, $65 ;$ in caves, $34,36-40,65$; Neolithic, $4 \mathrm{I}$; significance of his great antiquity, 66 ; origin and development of, 66 ; acquiring of intellect by, 67 ; average in mental capacity of, 159 ; psychologically transcends the highest apes immeasurably, 280,287 ; prolongation of infancy in, 280, 287; mental plasticity of, 289-291.

Manatee, rib of, 24.

Mandshus of the Mongolian race, 151.

Maples, in Miocene age, 22 ; in Pliocene, 27.

Marcus Aurelius, Emperor, and persecution, 194.

Margiana, the Muru of the Zendavesta, 71 .

Marsh, O. C., on mammalia in Triassic age, 5,6 ; his discovery of the atlantosaurus, 6 ; on palzontology of the horse, 335 .

Marsupials, Eocene, I7; Miocene, 22 ; in Australia, 320.

Mary Tudor, persecutions of, 232.

Mastodon, in Miocene age, 22 ; in Pliocene age, 27.

Materialism, as a term of abuse, 250 ; unintelligent use of the word, 250 ; legitimate changes of meaning in, 250 ; and modern philosophy, 251-257; its position in regard to mind and matter, $252-$ 257 ; as held at the present time, 252,253 ; as behind the times, 253 ; and the philosophy of the future, 257; on consciousness and physical action, 302 .

Maurer, G. L. von, method of, 176.

Mead, derivation of, 127.

Mecca, competition of bards at, 146.

Medes, country of the, 72 ; called Moles, Miocene, 22.
Aryans by Armenian writers, 74i their language one of the Aryan group, 74.

Mediterranean Sea, in Miocene age, 20 ; in Recent period, 40.

Mental plasticity, in the lower animals, 284,286 ; in the higher apes, 286 ; man's use of his, 289-29r.

Mental states and physical action, 303-306.

Merv, the Muru of the Zendavesta, 71.

Metaphysical problems, their place in the philosophy of the present age, 259.

Metaphysics, distinction between science and, 264.

Middle Ages, communication in, 143; excessive cruelty of, explained, 204.

Midget, meaning of the word, 126.

Military discipline of primitive society, 290.

Mill, J. S., his essay on Liberty, 213.

Million of years, our inadequate conception of, 10 ; geological work in $\mathrm{a}, \mathrm{I} \mathrm{I}$.

Mind-stuff, character of, 306.

Minokhired, Aryana Vaëjo in the, 73.

Miocene age, 7 ; physical contour of Europe in, 20; climate of Europe in, 21,60 ; vegetation in, 21,22 ; animals in, 22 ; doubtful if man existed in, 23-25; glaciation in, 60 .

Mississippi Valley, drainage of, 12.

Moguls of India of Mongolian race, I5I.

Mohammed and Arabian civilization, 171.

Mohammedans and Magian religion, 70.

Molecular motion, 254, 255.

Molecules, Clifford's description of, 296. 


\section{INDEX}

Mollusks, earliest, 5, 7 .

Mommsen's life of Cæesar, compared with Froude's, 182; sociological generalization in, 182 .

Money, Aryan words for, 121 .

Mongolian race, in northern Asia, 149, I 51 ; not to be confounded with Tatars, 150 ; its composition, 151 ; its dialects, how related, I $51-154$; never homogeneous, 153 .

Monkeys, intelligence of, 286.

Monotremes in Australia, 320.

Monsoons of the Indian Ocean, 64. Month in Aryan languages, 109, 137.

Moors as Iberians, 44. See Moriscoes.

Moral progress, 193-20I.

Morals and evolution, 276.

Moriscoes driven from Spain, 221, 231.

Morphology, facts of, in proof of Darwinian theory, 322.

Mortillet, Gabriel de, on existence of man in Miocene age, 24.

Mother, derivation of the word, 108.

Mountains, of Europe in successive ages, 15,16 ; as condensers, 61 .

Mouse, Aryan words for, 126 ; in Galapagos Islands, 315 .

Müller, Max, on the application of the term Aryan to Indo-European group, 80; his Science of Language, 156 .

Muru, creation of, by Ahura-Mazda, 69 ; is the modern Merv or Margiana, 71 .

Music, rudimentary beginnings of, 185.

Musk-sheep, Pleistocene, 29 ; in southern France, $3 \mathbf{I}$; in France and England, 32 ; companions of Cave-men and Eskimos, 39.

Mussulman civilization, $\mathbf{I} 7 \mathrm{I}$.

Must, an Old Aryan word, 127.

Myrtles, Miocene, 22.

Myth-makers, names of the earliest, unknown, 185 .
Natural selection, could not unaided have originated mankind, 280 ; discovery of, by Darwin, 323328 ; coincidence of Wallace's and Darwin's discovery of, 330 .

Necrolemur, 18.

Neolithic age, 4I.

Neolithic men, their grinding of stone implements, $4 \mathrm{I}$; their civilization, 42 ; their domestic animals, 42 ; their cultivated seeds and fruits, 42 ; diffusion of, in Europe, 43,44 ; physical characteristics of, 43 ; identical with the Iberian race, 44.

Neptune, planet, coincidence in its discovery, 332.

Netherlands in Eocene age, 16.

New Zealand, native plants and animals of, supplanted by foreign, 317.

Newgate, "stone-hold" of, done away with, 207.

Newton, Sir Isaac, buried by the side of C. R. Darwin, 308, 336; C. R. Darwin ranked with, 326, 336.

Nice, dialect of the newspapers of, 142.

Normandy in Eocene age, 16.

Norsemen considered a violent death the only honourable one, 204 .

North America, in Cretaceous period, 16 ; joined to Europe in Miocene age, 21 ; separated from Europe in Pliocene age, 26 ; in the glacial epoch, 30 ; repeatedly joined to Asia, 133.

North Pole, temperature of, as affecting ocean currents, 55.

North Sea, in Pliocene age, 26 ; in glacial epochs, 30 ; in Pleistocene age, 33 ; in Recent period, 40.

Northern hemisphere, causes of glaciation in, 48-56; cause of change of seasons in, 48, 54 ; climate of, $51,56$.

Norway in Pliocene age, 26. 


\section{INDEX}

Numerals, in Old Aryan, 114 ; in the language of Tahiti, 156 .

Oaks, in Cretaceous epoch, 6 ; in Miocene, 22 ; in Pliocene, 26.

Ocean-currents, as affecting glaciation of northern hemisphere, 53-56, 64 ; as produced by southern tradewinds, 54,64 ; as produced by northern trade-winds, 55 .

Oceans, their position practically the same throughout the ages, 13 ; changes in contour of, 14 .

Old Aryan, the language of Aryana Vaejjo, 81 ; reconstruction of, $108-113,137$; a vocabulary of, $112, I_{13}$; names of relatives in, 114 ; numerals in, 114. See Aryan, Aryans and Indo-European.

Old British as a division of Keltic, 85.

Old Norse as primitive form of Danish, Swedish, and Norwegian, 82 .

Old Prussian, as a branch of Lettic language, 87 ; extinct save in the Catechism of Albert of Brandenburg, 87 .

Ontology, Spencer and, $25^{8}$; interest in, will increase, 260 .

Opinions, relative truth of, 192 ; improvement in character of modern, 193; on religious matters, 225 ; diversity of, a guarantee of healthy intellectual activity, 225 .

Opossum, Miocene, 22.

Orang-outangs as the forefathers of man, 287.

Oriel window, 118 .

Origin of Species, the process of its conception traced, $315-328$; regarded by Darwin as a preliminary outline of his theory, 329 ; the times ripe for its acceptance, 330 .

Origins, present age wrapped in the study of, 259.

Origins of Protestantism, the, 221.

Ormuzd, his creation of the sixteen countries, 68.
Orthodoxies, decomposition of, 245 ; and individual responsibility, 263 .

Oscan, a division of the Italic language, 85 .

Ossetian of Caucasus, a division of Aryan speech, 83 .

Our Aryan Forefathers, 68-96.

Outlines of Cosmic Philosophy, on Conditions of Progress, 170 ; and sociology of Spencer, 170, 172 ; on Buckle's theory that changes in Arabian civilization before and after Mohammed were due to geographical environment, $17 \mathbf{1}$; on meaning of infancy, 279 ; on consciousness and molecular motion in the brain, 303 ; on matter and spirit, 307.

Owen, Sir Richard, assisted in publication of results of voyage of Beagle, 313.

Ox, Pliocene, 27; harbinger of civilization, 41 .

Oxus, the, 70 .

Pacific islanders, complexion of, 93. Palxolithic age, the stage of culture known as the, 34 .

Palfrey, origin of the word, 123 .

Pali, as a division of Aryan speech, 83.

Palmettos, Miocene, 22.

Palms, in Jurassic period, 6 ; in Pliocene age, 27.

Panther, Pliocene ancestor of, 27.

Parental feeling, its origin in the prolongation of infancy, 289 .

Paris, a political and intellectual centre, 142.

Parker, Theodore, on the justice of God, 206; and free-thinking, 246.

Paroquets, Miocene, 22.

Parrot, 286.

Parsi, sacred books of, 68 ; of Bombay, as a division of the Aryan language, 83 .

Parsis or Persians in Bombay and its neighbourhood, 70. 


\section{INDEX}

Patois, the rise of, $141-143,145$; the decay of, 143,145 .

Pecunia, pecus, and fee, relation of, 121.

Pelicans, Miocene, 22.

$P e n$ and feather, relation between, I05, 106.

Pepin and environment, 187.

Perihelion, earth's, 49, 50.

Permian epoch, mammals and reptiles of, 6, 7; glaciation in, 60 .

Persecution, causes of, 191-220; logical basis of, destroyed by Lessing's theory of the relative truth of opinions, 192 ; decline of the spirit of, $192,196,211$; decline of manifestations of, 192, 196, 210 ; Buckle's theory of the cause of, 194-196; the dogma of exclusive salvation and, 195; growth of scepticism diminishes, 196; its decline an illustration of man's intellectual and moral progress, 20r, 211 ; cruelties of, 204,205 ; diminished by industrialism, 210 ; spirit of, originated in the disposition to domineer, $2 \mathrm{II}$; originated in the assumption of infallibility; 213 ; originated in the desire to enforce religious unity, 224; the idea of corporate responsibility a cause of, $218,219,230-232$, 261 ; as the work of a paganized Christianity, 239.

Persian, modern, a division of Aryan speech, 83 ; Arabic words in, roo.

Persian Gulf in Tertiary period, 25.

Persians, led by Ahura-Mazda to Bombay, 70; migration of, from central Asia, 72 ; called Aryans, 73.

Peru, its flora and fauna compared with those of the Galapagos Islands, 316-3 I8.

Peter the Hermit and social conditions, I 74.

Pferd, history of the word, 123.

Pheasants, Miocene, 22.
Philip II., heretics burned at his marriage, 204; and the Spanish A rmada, 231 .

Philology, comparative, 78 ; an historical science, 112.

Philosophic attitude of the present age, 259.

Philosophy, modern, the charge of its being materialistic refuted, $25 \mathrm{I}-$ 257.

Pianist, training of the faculties necessary to a, 281 .

$\mathrm{Pig}$, and the anchitherium, 18 ; the harbinger of civilization, 41 ; used as money, 121 ; domesticated, 125, 324; teachable, 286.

Pigeons, variety in, produced by breeding, 324 .

Pines in Jurassic epoch, 6, 15.

Plasticity of mind in highly educated people, 216.

Pleistocene age, 7; vicissitudes of climate in, 29-31; European mammals of, 29-3I; riverdrift men in, 31 ; migration of animals in, 32 ; coincident with the glacial period, 59 ; climate of Europe in, 60.

Pliocene age, 7 ; physical contour of Europe in, 25 ; vegetation in, 26; mammals in, 27, 29; man found in Portugal and California during, 28 ; probable antiquity of, 66.

Po, the river, its work in geological denudation, 12.

Poetry, rudimentary beginnings of, 185 .

Polar regions, deciduous trees in the, 17.

Polish a branch of Slavonic speech, 87.

Political economy, the truths dealt with in, 177.

Pollock, Frederick, edits Clifford's Lectures and Essays, 292.

Poplars, in Miocene age, 22 ; in Pliocene age, 27.

Portugal, implements of human 


\section{INDEX}

workmanship in Pliocene strata of, 28.

Portuguese as a Latin language, 85 .

Positivism, the distinction between science and metaphysics drawn by, 264 ; and unity of belief, 264 .

Power, Divine, manifestation of, in the universe, 27I ; and right living, 271 ; asserted by the doctrine of evolution, 274 .

Prakrit language, 83 .

Priesthood, need of, in early ages of Christianity, 237.

Priestley, Joseph, as a materialist, 250; friend of Erasmus Darwin, 3 Io.

Primary period in geology, relative duration of, $3,4,7$.

Primates, Eocene, the link between man and horse, 18, 66.

Progressiveness, human, as aided by prolongation of infancy, 279-289; as achieved by mental plasticity, 289-291.

Pronunciation, differences of, 102.

Protective tariffs, 177.

Protestantism, True Lesson of, 244268; of early Christianity, 236 ; state of society which preceded its early manifestations, 239, 240; as protest against the church's assumption of corporate responsibility, 241,243 ; as assertion of individual rights and responsibility, $24 x, 247$; and total destruction of religious creeds, 246, 247 ; true lesson of, 266.

Provençal, as a Latin language, 85 ; a patois, 143.

Pumpelly, Raphael, on the cold in Siberia, 62.

Punjab in the Vedic hymns and Zendavesta, 71 .

Puppets, a world of, 257 .

Puritanism as a protest against the Pagan corruptions of the church, 240, 241.

Pushtu of Afghanistan, a division of Aryan speech, 83 .
Pyrenees, in Eocene age, 16; in glacial epoch, 30.

Quartzite implements of the riverdrift men, 35 .

Rabbits, Pleistocene, 29; Recent, 41 ; domesticated, 324 .

Race, community of, 95 .

Races of men, succession of, in Europe, 46, 92 .

Recent period, geographical structure of Europe in, 40 ; mammals in, $4 \mathrm{I}$; man in, $4 \mathrm{I}$.

Reindeer, Pleistocene, 29 ; in southern France, 3I ; Recent, 4I.

Relative truth of opinions, Lessing's theory of, 192.

Religion, and theology, 225 ; essence of true, 236 ; human speculation in regard to, 266,267 ; no conflict between science and, 249, 276.

Religions, wherein they agree and differ, 270 ; presence of a Divine Power in all, 271 ; essential truths of, $27 \mathrm{I}-274$.

Religious belief concerns only the individual, 266.

Religious unity, the aim of persecution, 244,261 ; the essence of, 225,263 ; is undesirable, 260 .

Reptiles, earliest, 5 ; of Jurassic epoch, $5,7$.

Representativeness, 200 ; and self. control, 201.

Rhine in Pleistocene age, 33.

Rhinoceros, Miocene, 22 ; Pliocene, 27; Pleistocene, 29; extinct species of, $3 I$.

Rhinoceros, big-nosed, contemporary of man in Britain, before the Pleistocene age, 34 .

Rhinoceros, woolly, 29; contemporary with the Cave-men, 36 ; extinction of, 41 .

Ribeiro, on discovery of traces "of man in Pliocene strata of Portugal, 28. 


\section{INDEX}

Right living, and Divine Power in the universe, 271,276 ; asserted by the doctrine of evolution, 277 .

Rigidity of mind in savages and uneducated people, 215.

River-drift men, 34- 36,46 ; contemporary with the big-nosed rhinoceros in Britain, 31, 48; disappeared from Europe in later Pleistocene age, 34 ; stone implements of, 35 ; diffusion of, 36 ; antiquity of, 65 .

Rivers, their part in geological denudation, 12.

Rocky Mountains, and geological denudation, 12 ; in the ice age, 31.

Rodents, Eocene, 19.

Romanic dialects, what they illustrate, 86.

Roman Empire, the, change in ideas of social obligation under, 233; the recognition of the individual established under, 233; decomposition of primitive ideas brought about by, 234 .

Romans, as Aryans, 76 ; their feeling of corporate responsibility, 230 .

Roof, Aryan words for, 117.

Rubinstein, A. G., training of his musical faculties, 282.

Rudimentary organs, 322.

Rumansch as a Latin language, 85 .

Rupee of Bengal, 121.

Russia in Tertiary period, 25 ; ecclesiastical services of, written in Old Bulgarian, 69.

Russian, modern, a branch of Slavonic speech, 87 .

Russians, central, light complexion of, 94 .

Samoyedic race, complexion of, 93 ; in northern Asia, 149, 151 ; allied to the Eskimos, 151 .

Sandalwood, Miocene, 22.

Sandwich, meaning of the word, 116. Sanskrit, studied after the English conquest of India, 78, 97 ; study Sea, Aryan words for, 128, 129. of, emphasized similarity of Greek and Latin, 78 ; literature of, the oldest in the world, 79 ; a sister, not a parent, language to Greek and Latin, 79 ; resemblance between Zend and, 83 ; words, in the Kawi of Java, 124 ; word for six, 135 ; kinship with the Latin, perfectly evident, 149; Vedic, one of the Aryan group, 74.

Saporta, Count, on deciduous trees, 17.

Sapta-Sindhavas of the Vedic hymns, 71.

Sarasvati, one of the "Seven Rivers," $7 x$.

Savages, their want of forethought, $19^{8}$; their rigidity of mind, 199 , 215 ; the clan their unit of $80-$ ciety, 217.

Scandinavia, in Silurian age, 14; Eocene, 16; Miocene, 21 ; its shores once washed by the waters of the Indian Ocean, 26; in glacial epochs, 30.

Scandinavian language, Teutonic speech as a branch of, 86 .

Scandinavians, complexion of, 94 .

Scherer, Edmond, on contemporary literature, 191.

Schlegel, Friedrich, conception of Indo-European family of languages first reached by, 79 .

Schleicher, August, his reconstruction of Old Aryan, 110; his Beiträge sur vergleichenden Sprachforschung, 111.

Schurz, Carl, at the farewell dinner to Spencer, 268.

Science, rudimentary beginnings of, 185 ; distinction between metaphysics and, 264.

Scotch divines, Mr. Buckle on, 197.

Scot-free, meaning of the term, 121 .

Scotland, in Cretaceous period, 16 ; in Miocene, 21 ; in Pliocene, 26; Gaelic language still spoken in, 85 . 


\section{INDEX}

Seasons, cause of change of, in northern hemisphere, 48.

Secondary period in geology, relative duration of, $3,5,7$; giant reptiles in, 6.

Sects, formation of Protestant, 244; decomposition of, a feature of the present day, $245,246$.

Sedimentary rocks, 12 ; of Europe, 15.

Self-control considered as a moral attribute, 201.

Semitic languages, futile attempts to prove that they are allied to Aryan languages, 135 ; a distinct family, $138,146$.

Servian a branch of Slavonic speech, 87.

Seville, depopulation of, 223 .

Shakespeare, William, and social conditions, 174.

Sheep, harbinger of civilization, 4I ; used as money, 121 ; domesticated by the Aryans, 125 .

Shetland mountains in Pliocene age, 26.

Shetland pony and the anchitherium, 18.

Siberia, in Tertiary period, 25 ; its cold winters, 62 ; languages of, belong to the Finno-Tataric family, 150.

Sicily, brigandage in, 208.

Silk-moths are domesticated, 324 .

Silures as Iberians, 45 .

Silurian period, 5,7 ; physical contour of Europe in, 14 ; glaciation in, 60 .

Simultaneous discoveries, $33 \mathrm{r}$.

Six, Hebrew and Sanskrit words for, 135.

Slavonic language, added to IndoEuropean group, 80 ; as the eighth grand division of Aryan speech, $8_{7}$; divisions of, 87 .

Slavs, their invasion of Europe, 45, 87 ; as Aryans, 76 ; have retained political independence in Russia alone, 87.
Slykick force, Clifford on, 305.

Snakes, in Galapagos Islands, 315 ; rudimentary hind limbs of, 322 .

Snow, earth's storing up of, 51 ; perpetual, confined to high altitudes, 62 .

Social object, the, as presented by Clifford, 301.

Social plasticity, in France and England, 291 ; in our own country, 291.

Sociology, and Hero-Worship, 158183 ; relation of the environment to the genius in, 162 ; Spencer on the study of, 165,170 ; the truths dealt with in, 176 ; study of, concerned with institutions rather than with individuals, 178 , 181 ; distinction between study of history and study of, 178-182.

Sogdiana the Sugdha of the Zendavesta, 71 .

Solids, 298.

Soul, conscious existence ot, after death, 265,307 .

South Africa as part of Aryan domain, 82.

South America, its flora and fauna compared with those of the adjacent islands, $315-318$; successive appearance of sloth-like and armadillo-like animals in, 320.

South Pole, effect of its temperature on ocean-currents, 54,64 .

Spain, in Silurian age, 15 ; in Cretaceous period, 16 ; brigandage in, 208 ; economic ruin of, dates from the expulsion of the Moriscoes, 223 ; warfare for religious unity in, 223; feeling of corporate responsibility at the root of persecutions in, 231.

Spaniards, related to French and Italians through Keltic ancestors, 90 ; complexion of, 94 .

Spanish as a Latin language, 85.

Spectrum analysis, simultaneous discoveries in, 332.

Speech, no such thing as an origirp 


\section{INDEX}

unity of, 135-139; power of, possessed by mankind for thousands of centuries, 136 ; community of, belongs to a later rather than to an earlier stage of progress, 145, 157. See Language.

Spencer, Herbert, his Study of Sociology, 165 ; on changes in communities due to the mutual actions of individuals, 165 ; Outlines of Cosmic Philosophy on sociology of, 170,172 ; on the great-man theory as held by Carlyle, 173$175,176,181$; on ontology, $25^{8}$; farewell dinner given to, 268 ; immensity of his work, 269,278 ; on care of the body, 293 ; on consciousness and molecular motion, 305 .

Spencerian evolutionists, 170.

Spencerian school, unwise use of the term, 163 .

Spitzbergen, in Eocene age, 16; deciduous trees in, 17; in Pliocene age, 26 ; perpetual snows of, 62.

Spontaneous variations, analogy between geniuses and, 158, 162; in species, 159, 160.

Sportsmanship esteemed and criticised, 208.

Squirrels, Miocene, 22 ; intelligence of, 285 .

Stephanus of Byzantium on Thrace, 80.

Stephen, Leslie, edits Clifford's Lectures and Essays, 292.

Stone age, Old, 34 ; river-drift men in, 34-36; Cave-men in, 3640 ; New, 4I ; farmers and shepherds in, $4 \mathrm{I}$.

Stone implements, of the river-drift men, 35 ; of the Cave-men, 37.

Stubbs, William, works of, 176.

Submergence, in Jurassic period, 15 ; in Eocene period, 16; in Miocene, 20.

Sugdha, creation of, by Ahura-
Mazda, 68 ; known by the ancients as Sogdiana, 71 .

Swine, Pliocene, 27.

Switzerland, in Silurian age, 15 ; in Cretaceous period, 16 ; Miocene, 20 ; lake-villages of, 42.

Symbols of faith, 237 .

Sympathies, human, widened by industrialism, 207.

Syriac language closely related to Hebrew and Assyrian, 146, 147.

Table, as a group of states of consciousness, 300 ; as the social object, $30 \mathrm{r}$.

Tahiti, numerals in the language of, 156.

Tapirs, Miocene, 22 ; Pliocene, 27 ; representative of, in Eocene age, 320.

Target shots as an illustration of variations in species, 161 .

Tartar and Tatar, 150.

Tartaric languages, spoken by nomadic tribes in Asia, 89.

Tears and grief, 254, 256.

Tennyson, Alfred, Lord, quotation from his In Memoriam, 225.

Tertiary period in geology, relative duration of, 3,7 ; aspect of na.. ture in, 6, 8; northern Asia in, 25.

Tertullian, his Credo quia impossibile, 237.

Teutonic character of English language, 100.

Teutonic language, the sixth grand division of the Aryan speech, 86 ; divisions of, 86.

Teutons, their invasion of Europe, 45,86 ; as Aryans, 76 ; diffusion of, from the time of Cresar to the fifth century, 86.

Theological renaissance, 260.

Theology and inscrutable realities of religion, 225 .

Thessaly, brigandage in, 208.

Thomson, Sir William, on antiquity of life on the earth, 8. 


\section{INDEX}

Thracians, ancient, as Goths, 86. Thumb, Tom, as a spontaneous variation, 159.

Thun, meaning of the word, 116.

Timbuctoo negroes in Grant Allen's theory of the causes of social progress, $169,173$.

Time, geological, divided into ten equal periods, 8 ; duration of periods in, 8, ro ; our inadequate conception of, 10 .

Timur, of Mongolian race, $15 \mathrm{I}$.

Toledo, Archbishop of, and expulsion of the Moors from Spain, 221.

Tortoise in Galapagos Islands, $3 \times 5$.

Torture, theory and practice of, 204 , 205.

Toulouse, a political and intellectual centre, 142.

Town, Aryan words for, 116.

Town-meeting, 177.

Trade-winds, 54, 64.

Trees, deciduous, in the Eocene age, $6,17$.

Triassic epoch, birds in, 5,7 ; physical contour of Europe in, 15 .

Tribal stage of social organization, 217. See Clan.

Trinity, doctrine of the, as a symbol of faith, 237; a less important doctrine in religion, 273.

Tungusians, members of the Mongolian race, 151 ; their language, how related to the other Mongolian languages, $151-154$.

Turanian language spoken by nomadic tribes of northern Asia, 89 .

Turkish language, brought into Aryan Europe by recent intruders, 89 ; one of the Altaic or FinnoTataric family of languages, $13^{8}$, 150; how related to the Finnish, 151 .

Turkistan, languages of, belong to the Finno-Tataric family, 150; formerly called Independent Tartary, 151 .

Turtle, instinct of, 282.
Tylor, E. B., his doctrine of survivals, 132 .

Umbrian, ancient, a division of Italic language, 85 .

Undulatory theory of light, simultaneous discoveries in, 332 .

Ungulata, Eocene, 19.

Unitarians and free-thinking, 246.

Universe of Mind-Stuff, 292-307.

Unknowable, the, applied to the eternal Power in the universe, 275.

Ur of the Chaldees, 43.

Ural Mountains in Tertiary Period, 26.

Urus, pictured by the Cave-men, $3^{8}$; in Recent period, 41.

Valencia, Archbishop of, and expulsion of the Moors from Spain, 221, 231 .

Variations in intelligence, $159-161$; in lower animals, 284, 286; in higher apes, 286 ; when seized upon by natural selection in preference to physical variations, 287 .

Variations in species, $159-161$; under domestication, studied by Darwin, 323, 324; and Darwin's discovery of natural selection, 326 .

Veda, and Zendavesta compared, 73; Aryans, in the, 74.

Vegetation of Europe, in the Eocene age, 17 ; in the Miocene, 21 ; in the Pliocene, 26.

Velocities of molecules, 297.

Vendidad, Ahura-Mazda in, 68 ; legends of, 113.

Veredus, the Low-Latin post-horse, I23.

Verification of scientific hypotheses, 264.

Vertebrate, earliest forms of fossil, 5 .

Viking, meaning of the word, 115 .

Village, Aryan words for, 115.

Virgin, an implement of torture, 205.

Visceral movements organized before birth, 283. 


\section{INDEX}

Vocabulary, community of, not enough to establish community of language, 98-101; of words borrowed and of words derived, 101, 102, 106, 107; of Old Aryan, $112,113$.

Volcanic heat, action of, on oldest rocks, 4 .

Volcanoes, of the Atlantic ridge in Miocene times, 21 ; of the British Isles, $21,26$.

Voltaire, F. M. A. de, and social conditions, 174.

Vowel-changes in Aryan languages, 108.

Wales in Miocene age, 21 .

Wall, Aryan words for, 117 .

Wallace, A. R., his Island Life, 14, 64 ; on snow and ice, 52 ; scientific achievements of, 319 ; coincidence between his discovery of natural selection and Darwin's, 330.

Wallachian as a Latin language, 85 .

Walnut-trees in Cretaceous epoch, 6.

War engines of the ancients, 188.

Warfare, necessity of, 189 ; decline of, in modern times, 189, 207 ; decline of the spirit of, 190, 192 ; considered criminal, 192 ; modern methods of, more humane, 192 ; in primitive society, 202, 290; extinction of private, 207.

Was there a Primeval Mother Tongue ? 132-157.

Waterhouse, assisted in publication of results of voyage of Beagle, 313.

Watt, James, and social conditions, 187,188 ; friend of Erasmus Darwin, 310.

Weapons, laws against carrying, 208.

Weasels, Miocene, 22 ; kept by the Greeks and Romans, 126.

Wedgwood, Hensleigh, cousin of C. R. Darwin, 311 .
Wedgwood, Josiah, grandfather of C. R. Darwin, 311 .

Welsh language as Kymric, 85 .

What we learn from Old Aryan Words, 97-131.

Whitney, J. D., on presence of man in Portugal during Pliocene period, 28; his Auriferous Gravels of the Sierra Nevada, 28.

Whitney, W. D., on Aryan language, 80; his Study of Language, 101 ; on the political organization of the primitive Aryans, 130.

Willows in Pliocene age, 27.

Windermere, meaning of the word, 128.

Window, Aryan words for, 118.

Wine, an Old Aryan word, 127.

Witanagemote, 177.

Wolf and the Lamb, fable of the, 212.

Wolves, Pliocene, 27 ; Pleistocene, 29; Recent, 4I ; representative of, in Eocene, 320.

Wundt, Wilhelm, his Physiologische Psychologie, 306.

Ximenes, Cardinal, his bonfire of books, 148.

Yakutsk, temperature of, 62 .

Youth, period of physical, according to Francis Galton, 308 ; of C. R. Darwin, 308, 309 .

Yule-tide, adoption of, 239.

Zarathustra or Zoroaster, 71.

Zend, one of the Aryan group, 74, 80,83 ; resemblance between Sanskrit and, 83 .

Zendavesta, Ahura-Mazda in, 68, 70 ; legend of the sixteen countries in, 68, 70 ; antiquity of, 69 ; and Veda, compared, 73.

Zoroaster, prophet of Ahura-Mazda, 71.

Zoroastrians, schism among, 73. 

AA $000115839 \quad 3$

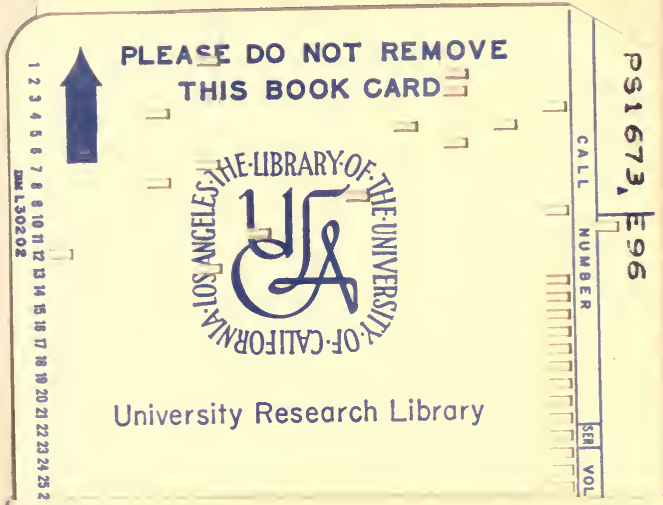


